
Editora Poisson

\section{Agroecologia em Foco Volume 1}

1a Edição

Belo Horizonte

Poisson

2019 
Editor Chefe: Dr. Darly Fernando Andrade

Conselho Editorial

Dr. Antônio Artur de Souza - Universidade Federal de Minas Gerais

Msc. Davilson Eduardo Andrade

Msc. Fabiane dos Santos Toledo

Dr. José Eduardo Ferreira Lopes - Universidade Federal de Uberlândia

Dr. Otaviano Francisco Neves - Pontifícia Universidade Católica de Minas Gerais

Dr. Luiz Cláudio de Lima - Universidade FUMEC

Dr. Nelson Ferreira Filho - Faculdades Kennedy

Msc. Valdiney Alves de Oliveira - Universidade Federal de Uberlândia

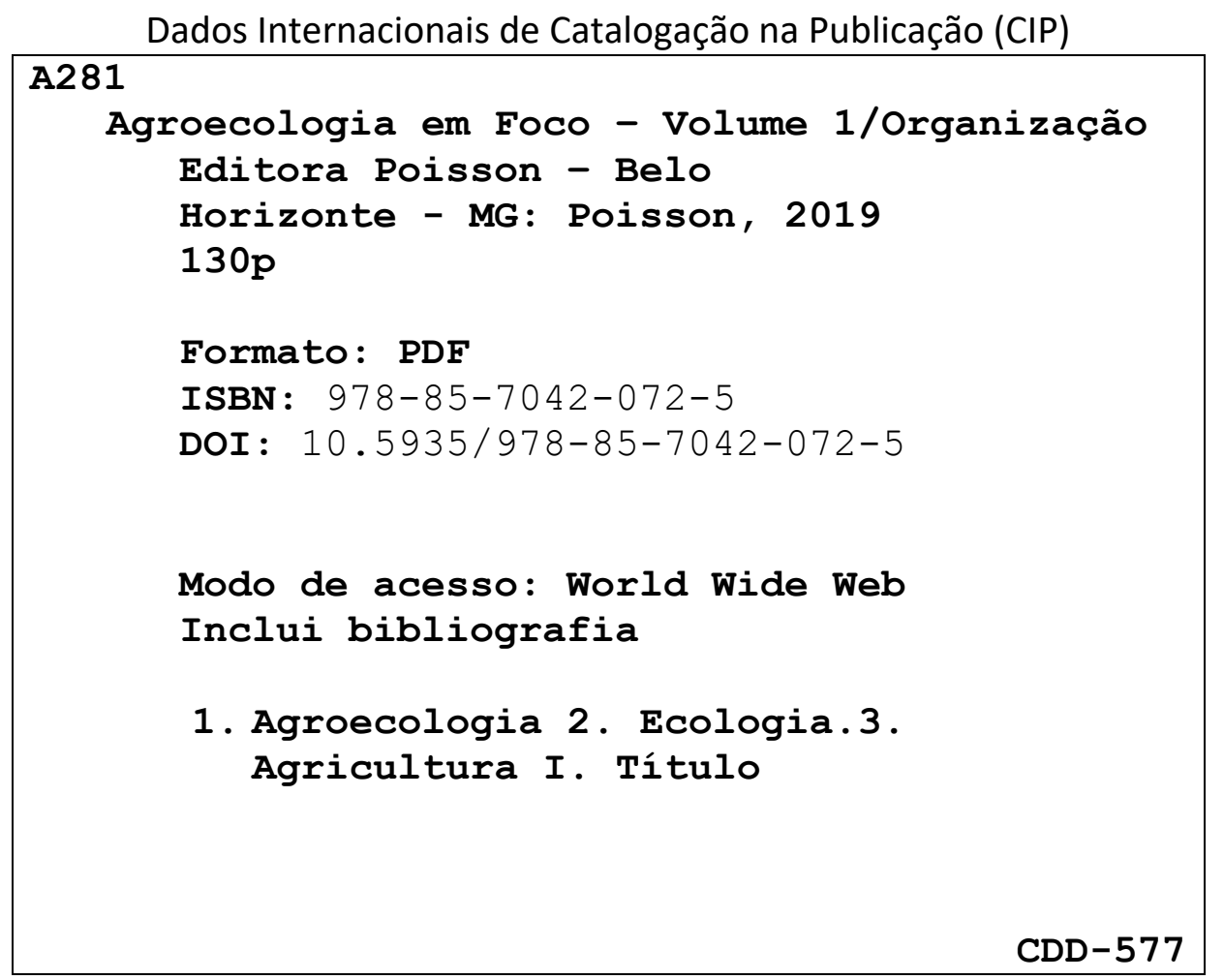

O conteúdo dos artigos e seus dados em sua forma, correção e confiabilidade são de responsabilidade exclusiva dos seus respectivos autores.

www.poisson.com.br

contato@poisson.com.br 


\section{SUMÁRIO}

CAPÍTULO 1: A EXTENSÃO NA PRESERVAÇÃO DA BIODIVERSIDADE DE

AGRICULTORES FAMILIARES NO ASSENTAMENTO VENEZA, PILÕES - PB 7

Shirley Santos Monteiro, Dualyson da Silva Santos, Juliana Ferreira de Lima, Andreia Vasconcellos, Fillipe Silveira Marini, João Gomes Oliveira Neto

CAPÍTULO 2: O PASTOREIO RACIONAL VOISIN (PRV) E A TRANSIÇÃO AGROECOLÓGICA NA AGRICULTURA FAMILIAR: EXPERIÊNCIAS EM CURSO NO MUNICÍPIO DE SANTA MARIA - RS 11

Josiane Rodrigues Miollo, Gisele Martins Guimarães

CAPÍTULO 3: ROMPENDO A INVISIBILIDADE POLÍTICA DA AGRICULTURA FAMILIAR DE QUEIMADOS-RJ 24

Jaime Rodrigo da Silva Miranda, Camila Cristina Nascimento da Silva, Bruno Tadeu Lopes

CAPÍTULO 4: O AVANÇO DAS LAVOURAS DE SOJA NA AMAZÔNIA MATO-GROSSENSE: PREOCUPAÇÃO OU DESENVOLVIMENTO? 28

Jôine Cariele Evangelista do Vale, Luany Alves Galvão, Rosimara Barboza Bispo, Rosimeire Barboza Bispo, Vera Lúcia Pegorini Rocha, Rosália do Nascimento da Silva, Marla Leci Weihs, Eduardo Darvin Ramos da Silva

CAPÍTULO 5: INTEGRAÇÃO AGROECOLÓGICA PELA SOBERANIA ALIMENTAR EM COMUNIDADE QUILOMBOLA NA AMAZÔNIA AMAPAENSE, BRASIL

Julia Franco Stuchi, Edilson Braga Rodrigues, Jorge Federico Orellana Segovia

CAPÍTULO 6: PROJETO NASCENTE VIVA: AC̄ÕES SOCIOECONÔMICAS E AMBIENTAIS NA RESERVA INDÍGENA DE DOURADOS - MS. 37

Vilela, Larissa Oliveira, Jessica Ferreira da Silva, Ana Caroliny de Queiroz Fernandes, Cleide Brachtvogel, Zefa Valdivina Pereira, Júlio César Pereira Lobtchenko

CAPÍTULO 7: A PRODUÇÃO CAMPONESA NO ASSENTAMENTO DE REFORMA AGRÁRIA SÃO JUDAS. 42

Francieli Aparecida Zenatti, Rodrigo Simão Camacho

CAPÍTULO 8: ASPECTOS SOCIOECONÔMICOS DA AGRICULTURA URBANA EM BAIRROS CENTRAIS DE TRÊS LAGOAS, MS 49

Thomás Floriano Boscaine, Ana Carolina Domingos Maluf, Clariana Vilela Borzone, Maria José Neto 


\section{SUMÁRIO}

CAPÍTULO 9: SISTEMAS DE PRODUCCIÓN DE CAFÉ ORGÁNICO EN CHIAPAS, MÉXICO 53

Etztli Itzel Morales Reyes, Miguel Ángel Balderas Plata, Salvador Adame Martínez, María Raimunda Araújo Santana

CAPÍTULO 10: EMERGÊNCIA DE PLÂNTULAS DE VARIEDADES CRIOULAS DE ALFACE EM SUBSTRATO ALTERNATIVO 61

Francisco Braz Daleprane, João Nacir Colombo, Mariana Zandomênico Mangeiro

CAPÍTULO 11: CARACTERIZAÇÃO E IMPORTÂNCIA DAS ESPÉCIES VEGETAIS PRODUZIDAS NA COMUNIDADE SANTA ROSA, CAPANEMA/PA, COM ÊNFASE NA AGROECOLOGIA 65

Karoline Roberta da Costa, Luan Daniel Silva Ferreira, Antonio Carlos Monteiro Filho, Diocléa Almeida Seabra Silva, Jorge da Cruz Macêdo Williams, Salma Saráty de Carvalho

CAPÍTULO 12: CONTROLE ALTERNATIVO DO FUNGO COLLETOTRICHUM GLOEOSPORIOIDES COM ÓLEOS ESSENCIAIS 73

Luana Souza Silva, Ana Paula da silva Rodrigues, Tainara Rafaely Medeiros, Grace Queiroz David, Walmor Moya Peres, Adriana Matheus da Costa Sorato

CAPÍTULO 13: CONTROLE ALTERNATIVO DE PENICILLIUM EM LARANJA 'PÊRA'... 77 Adriana Sorato, Marcelo Sicuto, Leila Corrêa, Daniel Carlesso, Grace David, Tainara Medeiros

CAPÍTULO 14: BIOATIVIDADE DO EXTRATO AQUOSO DE AÇAFRÃO NO DESENVOLVIMENTO MICELIAL DE PHYTOPHTHORA CAPSICI. 81

Ana Paula Rodrigues da Silva, Grace Queiroz David, Giseudo Aparecido de Paiva, Adriana Matheus da Costa Sorato, Walmor Moya Peres, Luana Souza Silva

CAPÍTULO 15: PERCEPÇÕES DO FAZER NA AGRICULTURA ECOLÓGICA: AS CONTRADIÇÕES DA “ROÇA LIMPA"” E DA “NÃO LIMPA". 85

Iara Aquino Henn, Serinei César Grigolo

CAPÍTULO 16: PARTICIPAÇÃO DA JUVENTUDE RURAL DA ESCOLA FAMÍLIA AGRÍCOLA DE ORIZONA EM SISTEMAS AGROECOLÓGICOS

Vanislene Borges da Silva, João Torres Franco Borges, Renata Pires Batista, Wilson Mozena Leandro, Warde Antonieta Fonsceca Dos; Zang 


\section{SUMÁRIO}

CAPÍTULO 17: EDUCAÇÃO AMBIENTAL EM CONJUNTO COM PRÁTICAS DE RECUPERAÇÃO DE NASCENTE EM UMA COMUNIDADE RURAL DE IRITUIA - PA...... 94

Karolainy Souza Gomes, Krishna de Nazaré Santos de Oliveira, Maria do Socorro Pires Souza, Raimundo Marly Carvalho de Farias Neto, Tiago Farias Peniche

CAPÍTULO 18: VISITA TÉCNICA: À AGRICULTURA FAMILIAR DE BASES AGROECOLÓGICAS NO CERRADO SUL-MATO GROSSENSE.

Maria Juanna Marques de Amurim-Santana, Franciele Nogueira Paz, Mariele Ramona Torgeski, Tabata

Alves Correa, Zefa Valdivina Pereira

CAPÍTULO 19: MOTIVAÇÕES DE PROFESSORES PARA TRABALHAR COM AGROECOLOGIA NA EDUCAÇÃO FORMAL 104

Diane Ivanise Fiamoncini, Claudia Pato

CAPÍTULO 20: SEMEAR A TERRA E PLANTAR SABERES: O TRABALHO DE UM COLETIVO AGROECOLÓGICO EM AQUIDAUANA-MS.

Gabriel Loschiavo Cerdeira, Sabrina Policarpio Souza Campos, Julia Caroline Machado de Araujo, Gabriel

Aparecido Saldanha, Camilo Alejando Bustos Avila

Autores: 


\section{Bapítulo 1}

A EXTENSÃO NA PRESERVAÇÃO DA BIODIVERSIDADE DE AGRICULTORES FAMILIARES NO ASSENTAMENTO VENEZA, PILÕES - PB1

\section{Shirley Santos Monteiro}

Dualyson da Silva Santos

Juliana Ferreira de Lima

Andreia Vasconcellos

Fillipe Silveira Marini

João Gomes de Oliveira Neto

Resumo: A seleção massal é a técnica de melhoramento mais antiga e a mais utilizada, por ser uma técnica simples e fácil. 0 trabalho teve como objetivo de propor alternativas para ampliar o progresso genético e a formação dos bancos de sementes comunitários. 0 experimento foi conduzido no Assentamento Veneza em Pilões - PB, em duas etapas na primeira etapa, foram realizada capinas e posteriormente o plantio das cultivares, na segunda etapa, realizou a colheita, seleção massal e armazenamento dos grãos. 0 plantio foi realizado em mutirão pelos agricultores, estudantes, professores e técnicos. 0 plantio foi feito em curva de nível, com milho e fava plantados consorciados na mesma cova, já o feijão foi plantado em fileiras duplas entre as fileiras de milho. No solo foi aplicado biofertilizante como fonte de nutrientes, produzido em mutirão pela comunidade. 0 campo de multiplicação representa a soberania alimenta da comunidade no processo de construção popular e autônoma das famílias.

Palavras-chave: Agroecologia; Produção vegetal; Sustentabilidade; Seleção massal. 


\section{INTRODUCC̃̃O}

O espaço agrário do Brejo Paraibano foi ocupado inicialmente com base na produção de alimentos em pequenas unidades de produção, mas logo cedo se desenvolveu o cultivo da cana-de-açúcar destinada, em princípio, à produção do açúcar mascavo para o autoconsumo, que na fase do apogeu do proálcool, a cana expandiu-se fortemente na região. Parte dos antigos moradores foram expulsos do campo e transformados em assalariados na própria atividade canavieira. Pequenos produtores da região também buscavam no corte da cana o complemento da renda familiar. Com a crise do proálcool e o fechamento das duas grandes usinas de açúcar da região (Usina Santa Maria e Usina Tanques), observou-se o aumento do desemprego mesmo que sazonal e a transformação de terras da usina, antes cobertas de cana, em áreas de pequena produção de alimentos (Lima; Mello, 2009).

Dentro desse contexto surge o Assentamento Veneza em Pilões-PB, na falência da Usina Santa Maria em 1994, os trabalhadores ficaram sem emprego. Com a contribuição do Sindicato dos Trabalhadores Rurais e movimentos sociais, os agricultores iniciaram sua luta pela terra. Em 1998, foi anunciada a desapropriação das terras da antiga Usina Santa Maria.

A partir daí se deu o processo de resgaste de experiências pelos agricultores e assentados começaram a potencializar o trabalho de resgate das sementes crioulas por meio do trabalho da Rede de Sementes da Paixão organizado pela Articulação do Semiárido paraibano (ASA-PB). Teve como objetivo, propor alternativas para ampliar o progresso genético e a formação dos bancos de sementes comunitários.

\section{METODOLOGIA}

O campo de multiplicação foi implantado no Assentamento Veneza, localizado no município de Pilões-PB,

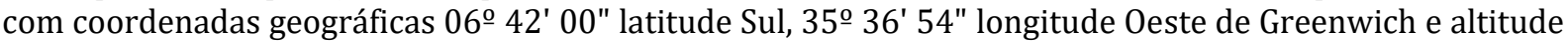
de 334 m e clima tropical chuvoso (Classificação climática de Koppen-Geiger: As).

Realizou-se reuniões de planejamento de implantação do campo de multiplicação, entre assentados, técnicos, estudantes e organizações da sociedade civil. A partir do anseio dos agricultores foram escolhidas as sementes de milho Jaboatão (Zea mays L.), fava (Phaseolus lunatus L.) e feijão macassar (Vigna unguiculata L.).

A implantação do campo de multiplicação de sementes crioulas foi realizada em maio de 2013, utilizando as sementes proveniente do Banco Comunitário de Sementes Crioulas de Alagoa Nova-PB, do guardião de sementes, José de Oliveira Luna (Zé Pequeno). 0 solo predominante no município são os Argissolos Vermelho - Amarelos e os Neossolos Litólicos (Campos; Queiroz, 2006).

0 plantio foi realizado em mutirão pelos assentados, estudantes, professores e técnicos. 0 plantio foi feito em curva de nível, com milho Jaboatão e fava plantados consorciados na mesma cova, o feijão macassar foi plantado em fileiras duplas entre as fileiras de milho. No solo foi aplicado biofertilizante como fonte de nutrientes, produzido em mutirão pela comunidade. Para produção do biofertilizante foi utilizado um tonel de $200 \mathrm{~L} \mathrm{e} 80 \mathrm{~L}$ de água, dois tabletes de rapadura (melaço), $40 \mathrm{~kg}$ de esterco, casca de ovos, cinza de fogão a lenha, pó de rocha (MB4), melão de são caetano (Momordica charantia L.) em seguida o tonel foi lacrado. A partir da oficina foi possível produzir $200 \mathrm{~L}$ de biofertilizante.

Foi realizado o desbaste do milho, deixando apenas 3 plantas/cova, eliminou as plantas mais raquíticas e/ou com ataques de pragas, favorecer o crescimento das melhores plantas. Aos 175 dias após o plantio foi realizada a colheita, seleção e avaliação do campo de multiplicação de sementes crioulas. 0 campo possui um total de 974 plantas.

A colheita no campo foi realizada em três classe: a 1 classe contendo cerca de $10 \%$ da produção, constituído das melhores plantas do campo escolhidas aleatoriamente pelos assentados, levando em consideração as características elencadas pelos mesmos. Na 2 classe, constituído pelas espigas não selecionadas pelos assentados na 1 classe, e a 3 classe, constituído pelas plantas que estavam na borda do campo, pois as mesmas possuíam risco de cruzamento com campos de milho vizinhos. Na seleção, o milho colhido foi dividido de acordo com as características descritas nos lotes citados anteriormente na colheita de campo.

Após a colheita o milho foi levado para o galpão, retirada as palhas e realizada a seleção massal, onde os assentados a partir de seus conhecimentos e experiências, elencaram quais características eram observadas para escolher as espigas, para retirar sementes, bem como para descarta-las. Após a seleção foi realizada a debulha de forma coletiva, levando em consideração retirar das espigas as melhores 
sementes que se encontram no terço central da espiga. Após a debulha foi realizado à avaliação participativa das ações desenvolvidas durante as atividades de manejo do campo de multiplicação de sementes crioulas, encaminhando-se em seguida para as ações que devem ser melhoradas para os próximos campos de multiplicações.

\section{RESULTADOS E DISCUSSÃO}

Na condução do campo de multiplicação o ataque de pragas, principalmente a lagarta do cartucho (Spodoptera frugiperda), no milho não chegou a níveis de danos a produção. Segundo Cruz e Turpin (1982), os danos ocasionados pela lagarta do cartucho do milho podem provocar perdas significativas que variam de 15 a 34\% da produção total no cultivo do milho.

A colheita do milho foi realizada de forma participativa resultando em 50,800 kg de milho selecionado sendo a classe 1 responsável por 12,500 kg, a classe 2 com 17,000 kg e classe 3 com cerca de 21,300 kg, identificadas de acordo com as classes apresentadas na metodologia.

No campo de multiplicação não obtivemos produção do feijão macassar, devido a impossibilidade do crescimento do feijão pelo porte elevado e sombreamento pelo milho Jaboatão, além do pequeno espaço que o feijão foi submetido.

$\mathrm{Na}$ colheita foram elencadas várias características observadas pelos agricultores para a escolha das melhores espigas, as mesmas foram repetidas por outros agricultores (Tabela 1).

Tabela 1. Características de qualidade observadas e vezes citadas dessas características do milho crioulo, na seleção massal participativa elencados pelos assentados (as) do Assentamento Veneza, Pilões - PB,

2013.

\begin{tabular}{|l|l|}
\hline \multicolumn{1}{|c|}{ Características observadas } & Vezes elencadas pelos agricultores \\
\hline Adaptação na área & 2 \\
\hline Altura da planta no campo & 1 \\
\hline Comprimento da espiga & 1 \\
\hline Cor & 1 \\
\hline Diâmetro da espiga & 1 \\
\hline Enchimento de espiga & 2 \\
\hline Espaçamento & 4 \\
\hline Espiga comprimento da espiga & 1 \\
\hline Espigas sadias & 1 \\
\hline Formato da palha & 1 \\
\hline Grãos grandes & 1 \\
\hline Milho "pontinha" & 1 \\
\hline Plantas sadias & 1 \\
\hline Produção por cultivo & 1 \\
\hline Quantidade de grãos & 1 \\
\hline Quantidade de palha & 4 \\
\hline Resistência a pragas & 1 \\
\hline Sabugo fino & 1 \\
\hline Sem palha na ponta da espiga & 1 \\
\hline Tamanho da espiga & 1 \\
\hline Tamanho das plantas & 4 \\
\hline Umidade da espiga & 1 \\
\hline Uniformidade das fileiras de espigas & 1 \\
\hline
\end{tabular}

Percebe-se que as características mais elencadas pelos assentados para a escolha de melhores espigas foram o item espaçamento do plantio que teve 4 menções, pois os assentados perceberam que neste ponto o campo de multiplicação não foi bem planejado. Destacou-se também pela à adaptação da semente na área, qual os assentados acharam que o milho adaptou-se, a quantidade de palha presente na espiga, pois não é interessante espigas com muita palha e sim com muita semente, tamanho das plantas, pois segundo os assentados as características da planta indicam as potencialidades da semente e enchimento de espiga, se as espigas estão cheias de sementes ou com muitas falhas, como também foi citado algumas características que fizeram os agricultores descartar as espigas como o mofo na espiga. Estas 
características e justificativas foram elencadas pelos 8 (oito) assentados que estavam presentes na avaliação do campo de multiplicação de sementes crioulas.

O milho da terceira classe (plantas da borda do campo) continham grande quantidade de gorgulho, faltavam sementes e eram desuniformes. Na avaliação do campo de multiplicação foi comentado que a colheita foi importante ter sido escolhido pela fase da lua, pois segundo experiência do assentado Assis Nogueira a melhor época de colher é quando a lua estiver cheia, pois evita a presença de gorgulho (Sitophilus zeamais) nas espigas do milho.

Existe uma grande resistência dos assentados com relação à adoção de práticas conservacionista no uso dos solos, como no caso da queima do material vegetal da área, que ao invés de ser queimado o material devia ser feito uma barreira com o material vegetal retirado da limpa para que depois ocorrer a contenção de partículas e nutrientes da parte superior da área. Percebeu-se que uma parte da área as plantas apresentaram baixa quantidade de espigas e muitas plantas raquíticas, essa parte do terreno encontravase um solo de textura mais arenosa e de cor mais esbranquiçada, diferenciando-se da área onde o solo era mais escuro com alta presença da matéria orgânica.

Pontos elencados na avaliação foram: aumentar o campo de multiplicação e a participação dos assentados, iniciar o plantio no início do ano seguinte, realizando o preparo da área em janeiro, realizar o plantio no mês de março, ou nas primeiras chuvas, fazer todo o manejo da área nos momentos corretos, fazer a avaliação no ponto verde do milho para detectar melhores condições das plantas no ponto de maturação, planejar e ampliar os trabalhos coletivos para outras áreas do assentamento, e no próximo ciclo de cultivo plantar o milho e a fava sendo avaliado positivamente, já o feijão solteiro foi avaliado como sendo um ponto negativo. Foi importante a construção coletiva do conhecimento agroecológico no que diz respeito aos processos produtivos utilizados na condução do campo de multiplicação de sementes crioulas.

\section{CONCLUSÃO}

O campo de multiplicação é um exemplo para as famílias assentadas e para comunidade técnica e acadêmica do que representa verdadeira soberania alimentar dos agricultores familiares, onde o assentado sabe de onde vem sua semente, seu alimento.

O processo de interação, junto com a formação popular técnica acadêmica unido nesse processo de construção da organização dos assentados potencializando um elo de liberdade que resulta no mais importante dentro da autoestima do ser humano a autonomia e a liberdade do seu alimento.

\section{REFERÊNCIAS}

[1] Campos, M. C. C; Queiroz, S. B. Reclassificação dos perfis descritos no Levantamento Exploratório Reconhecimento de solos do estado da Paraíba. Revista de Biologia e Ciências da Terra, v. 6, n. 1, 2006.

[2] Cruz, I.; Turpin, F. T. Efeito da Spodoptera frugiperda em diferentes estágios de crescimento da cultura de milho. Pesquisa Agropecuária Brasileira, Brasília, v.17, n. 3, p. 355-359, 1982.

[3] Lima, F. S.; Mello, F. S. Espaço agrário e pequena produção no brejo paraibano: o caso da floricultura na comunidade avarzeado. In: XIX Encontro Nacional De Geografia Agrária. São Paulo. p. 1- 21, 2009. 


\section{Bapítulo 2}

O PASTOREIO RACIONAL VOISIN (PRV) E A TRANSIÇÃO AGROECOLOGICA NA AGRICULTURA FAMILIAR: EXPERIENCIAS EM CURSO NO MUNICÍPIO DE SANTA MARIA - RS

Josiane Rodrigues Miollo

Gisele Martins Guimarães

Resumo: Este artigo discute experiências em Pastoreio Racional Voisin (PRV), a partir de cinco propriedades familiares localizadas em Santa Maria- RS. Argumenta-se sobre a potencialidade do PRV como sistema produtivo capaz de promover a transição agroeocológica na agricultura familiar contribuindo com o desenvolvimento rural sustentável a partir da utilização racional dos recursos naturais, relações positivas ser humano/natureza, oportunidades de geração de trabalho e renda e ainda possibilidade de reversão ao êxodo seletivo entre mulheres e jovens.

Palavras-chave: Agricultura Familiar, Transição Agroecológica, Desenvolvimento Rural Sustentável. 


\section{INTRODUCC̃̃O}

O reconhecimento da Agricultura Familiar enquanto segmento socioprodutivo com características especificas e importância econômica para o crescimento do País se deu a partir da década de 90, bastante impulsionado pela criação em 1992 do Programa Nacional de Fortalecimento da Agricultura Familiar (PRONAF). Neste percurso a delimitação desta, enquanto categoria política foi reconhecida em 2006, com a criação da Lei no 11.326 , de 24 de julho de 2006, que diz em seu artigo 3:․

Para os efeitos desta Lei, considera-se agricultor familiar e empreendedor familiar rural aquele que pratica atividades no meio rural, atendendo, simultaneamente, aos seguintes requisitos: I - não detenha, a qualquer título, área maior do que 4 (quatro) módulos fiscais; II - utilize predominantemente mão de obra da própria família nas atividades econômicas do seu estabelecimento ou empreendimento; III - tenha renda familiar predominantemente originada de atividades econômicas vinculadas ao próprio estabelecimento ou empreendimento; IV - dirija seu estabelecimento ou empreendimento com sua família (BRASIL, 2006).

Segundo França, Grossi e Marques (2009), no Censo Agropecuário de 2006 foram identificados 84,4\% estabelecimentos brasileiros caracterizados como de agricultores familiares, estes utilizando $24,3 \%$ das áreas agricultáveis. Já os estabelecimentos não familiares representam $15,6 \%$ do total dos estabelecimentos e ocupam $75,7 \%$ das áreas, deixando clara a concentração fundiária existente no País (IBGE, 2006).

Dados do Censo Agropecuário ainda indicam que apesar dos agricultores familiares ocuparem pequena parte das áreas de potencial agrícola (24,3\%), estes são responsáveis por $38 \%$ do valor bruto da produção agropecuária do País com destaque para produtos como arroz, feijão, mandioca, leite, ovos, carne de frango, carne suína, entre outros (IBGE, 2006) elencando a categoria como fundamental para a soberania alimentar, a partir da produção de alimentos para o abastecimento interno.

Nesse contexto de compromissos com a soberania e segurança alimentar um dos principais desafios da agricultura familiar está na produção de alimentos "limpos", com a minimização do uso de agrotóxicos e construção de estratégias de reprodução social e econômica que contemplem desde a produção até a comercialização dos produtos. Tais estratégias articulam o que se convencionou a chamar de "novos modelos sociotécnicos", que segundo Herrera e Ugarte (2008) constituem modelos organizativos de produção que envolve um "saber fazer" e um "saber agrupar-se", construindo assim novas tecnologias e formas de gestão no uso dos recursos naturais.

Na agricultura, para que um agroecossistema caminhe em direção à sustentabilidade é preciso perseguir sistematicamente algumas metas como a incorporação de processos naturais no sistema produtivo, redução no uso de insumos não renováveis com potencial de danos ao meio ambiente e a saúde humana, diminuição de custos no processo produtivo, formas socialmente justas de agricultura, reconhecimento e ainda respeito das práticas e conhecimentos locais (ALTIERI, 2004).

Tem-se assim a Agroecologia como modelo sociotécnico para a sustentabilidade, modelo este que procura ir além dos aspectos tecnológicos da produção, incorporando dimensões que incluem tanto variáveis econômicas, sociais e ambientais, como variáveis culturais, políticas e éticas da produção agrícola (CAPORAL; COSTABEBER, 2004).

Levando-se em consideração os desafios para implantação de um sistema agroecológico é importante que se atente para este como um processo gradativo que promove aos poucos a transição entre os modelos, uma vez que as mudanças são graduais dentro dos agroecossistemas, desde a desintoxicação do solo até a incorporação de princípios ecológicos na vida do agricultor promovendo inclusive mudanças nas atitudes e valores deste, em relação ao manejo e conservação dos recursos naturais (CAPORAL; COSTABEBER, 2004).

Dentro deste contexto de desafios assumidos pela agricultura familiar para sustentabilidade aponta-se a tecnologia do Pastoreio Racional Voisin (PRV) como um modelo impulsionador da transição agroecológica em sistemas de produção animal, capaz de proporcionar uma maior racionalização econômico-produtiva nas propriedades, bem como mudança nas atitudes e valores dos produtores em relação ao manejo e conservação dos recursos naturais (PINHEIRO MACHADO, 2010).

Objetivando identificar as potencialidades do PRV para a transição agroecológica na agricultura familiar, realizou-se uma pesquisa exploratória em cinco propriedades no município de Santa Maria-RS. Este 
trabalho é resultado de Estágio Curricular Supervisionado em Zootecnia, realizado junto a Emater municipal, que desde 2011 vem investindo na formação e atuação de agricultores familiares em PRV, como estratégia de desenvolvimento rural sustentável.

\section{PASTOREIO RACIONAL VOISIN COMO POTENCIALIZADOR DA TRANSICÃ̃O AGROECOLOGICA}

O Pastoreio Racional Voisin (PRV) é um sistema racional de manejo de pastagem que preconiza a divisão da área de pasto em parcelas, com fornecimento de água fresca, sal mineral e sombra aos animais (Figura 1). De acordo com Pinheiro Machado (2010) este sistema produtivo foi desenvolvido pelo francês André Voisin, logo após o término da Segunda Guerra Mundial, visando ampliar a produtividade e o valor biológico das pastagens, aumentando gradativamente a fertilidade do solo, produzindo alimentos livres de insumos químicos industriais e respeitando o bem-estar animal. Com isto compreende-se seu potencial como modelo produtivo capaz de promover a sustentabilidade da produção e reprodução social dos produtores (PINHEIRO MACHADO, 2010).

O PRV possui sua dinâmica baseada em quatro princípios, que são denominadas por Pinheiro Machado (2010) como "Leis Universais do PRV": A Lei do Repouso, a Lei da Ocupação, a Lei do Rendimento Máximo e a Lei do Rendimento Regular, estas leis têm grande importância e devem ser seguidas para obter resultados satisfatórios no sistema.

A Lei do Repouso estabelece que entre um pastejo e outro, é necessário passar um tempo suficiente para que o pasto armazene em suas raízes reservas de nutrientes para o início de um rebrote rigoroso. Dessa forma, o período de repouso entre os pastejos sucessivos é variável e depende de diversos fatores externos como a espécie vegetal, clima da região, fertilidade do solo, estação do ano. A altura do pasto não é considerada como referência para estipular o tempo de repouso da parcela, e sim o estado de desenvolvimento da planta.

A Lei da Ocupação se refere ao tempo de ocupação da parcela pelos animais, neste caso, o pasto não deve ser cortado duas vezes em um mesmo período pelos dentes do animal. Sendo assim, essa lei complementa a Lei do Repouso, pois se o animal cortar o pasto duas vezes durante o mesmo período de ocupação da parcela, este pasto não terá um período de repouso suficiente para se recuperar do primeiro corte. 0 tempo essencial de ocupação deve ser curto, pois os animais não devem comer o rebrote do pasto, se caso ocorrer, o primeiro passo para a degradação da pastagem estará dado.

A Lei do Máximo Rendimento, por sua vez, ocorre quando as duas leis anteriores são cumpridas, pois os rendimentos serão máximos. A pastagem com 15 a $25 \mathrm{~cm}$ de altura proporciona a quantidade máxima de pasto de melhor qualidade, isso em condições climáticas normais (essa altura foi recomendada por Voisin em pastagens europeias e não deve ser tomado como regra quando se trabalha com espécies subtropicais e tropicais). Caso a altura da pastagem exceda muito, o pasto acabará ficando mais fibroso e menos digestível com alta concentração de lignina, além de perder sua qualidade nutricional e diminuir sua palatabilidade.

A qualidade nutricional do pasto varia conforme a espécie, o estádio fenológico da planta e suas partes, os estratos mais altos são mais jovens e possuem menor conteúdo de parede celular, o que os torna mais digestíveis e palatáveis. Então os animais de maiores exigências nutricionais devem consumir o estrato superior da pastagem, para obterem o máximo de consumo de alimento com alta qualidade, já os animais de menores requerimentos nutricionais podem pastar o estrato inferior da pastagem. Este manejo é denominado de desnate e repasse, que permitem maximizar a produção, pois está aliado a uma alta carga animal, que resulta em alta produtividade por área, além de proporcionar alto desempenho individual para os animais do desnate.

Por fim, completando as quatro Leis Universais do PRV, a Lei do Requerimento Regular determina que para que um animal possa dar rendimentos regulares é preciso que não permaneça por mais de três dias em uma mesma parcela e os rendimentos serão máximos se esse animal não permanecer mais de um dia na mesma parcela. Neste caso, um animal alcança o máximo de desempenho no primeiro dia de pastoreio, e os rendimentos vão diminuindo a medida que o tempo de ocupação naquela parcela aumenta, pois, à medida que o animal vai pastoreando mais fundo, vai colhendo menor quantidade de pasto e com qualidade nutricional cada vez mais inferior. A seguir a Figura 01 exemplifica o uso dos piquetes segundo a disponibilidade de forragens. 
Figura 01: Exemplo de Rotação no uso de Piquete, em um Sistema de PRV.

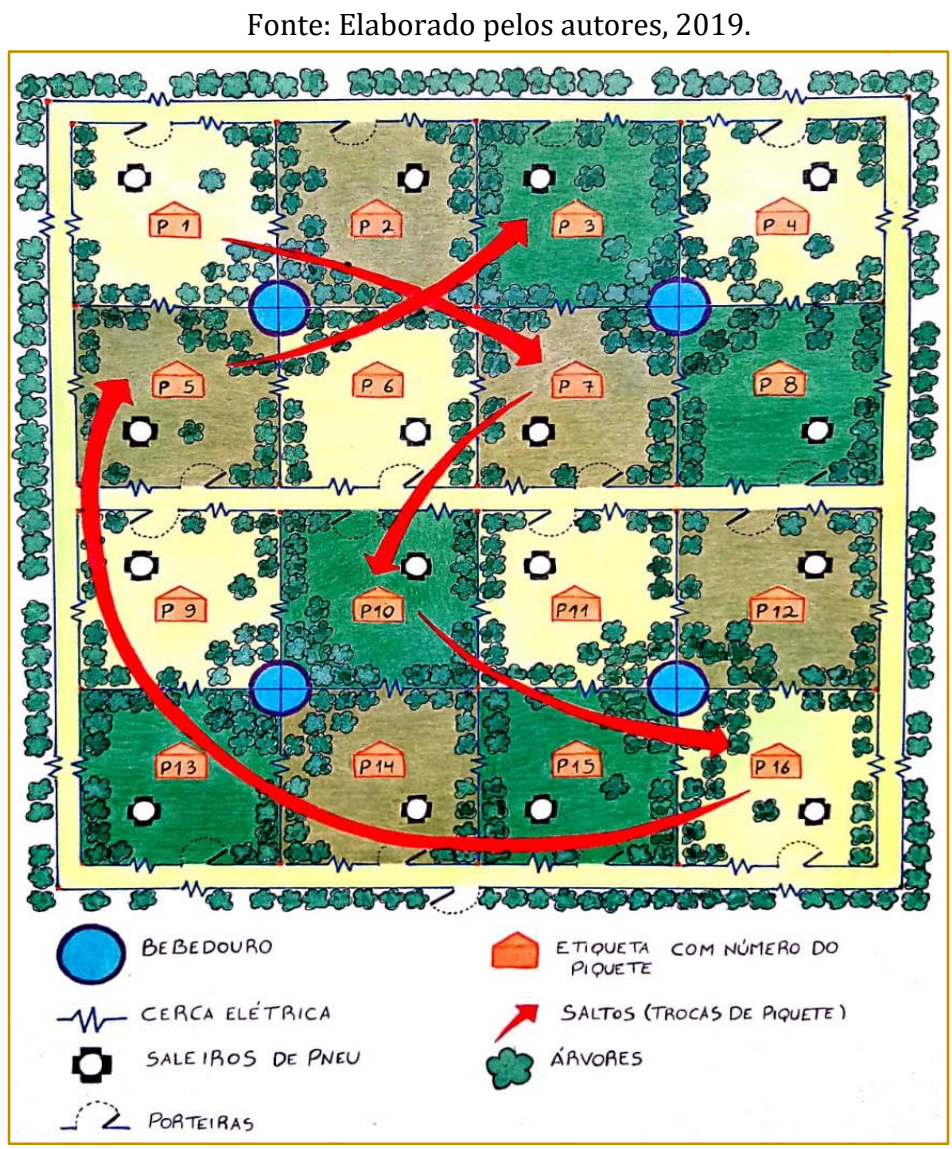

De acordo com Pinheiro Machado (2010), com a implantação do sistema de PRV os impactos ambientais são reduzidos, pois os animais de corte são abatidos mais jovens, dessa forma diminuindo a emissão de metano naturalmente proveniente da digestão ruminal. Um outro fator importante na minimização dos impactos ambientas é o manejo das pastagens, pois os pastos são consumidos em seus pontos ótimos de repouso, quando a relação fotossíntese-respiração é mais propícia a maior sequestro de carbono, neste estágio vegetativo o pasto está menos lignificado, o que também contribui para a redução na emissão de carbono.

Além disso, o PRV favorece a proteção ambiental ao contribuir com a microbiologia do solo, favorecendo a presença de insetos como o besouro "rola-bosta" (Digitonthophagus gazella e Dichotomius anaglypticus) que tem importante função na incorporação da matéria orgânica no solo (PINHEIRO MACHADO, 2010). Porém para ocorrer a presença deste besouro, o uso de biocidas deve ser limitado ou nulo e as pastagens devem ser preferencialmente nativas, pois já estão adaptadas ao agroecossistema local. Caso não exista campo nativo, deve-se buscar por espécies de fácil adaptação ao local onde serão implantadas.

Pinheiro Machado (2010) destaca um conjunto de indicadores positivos do PRV como o aumento da produtividade do pasto e disponibilidade deste o ano todo, a capacidade de promover alta produtividade a baixo custo, redução na erosão do solo pelo uso de piquetes, promoção de bem-estar dos animais ao fornecer água, pasto de qualidade e sombra em todas as parcelas e com isso diminuindo o estresse que afeta a imunidade dos animais, estes acabam por ficar mais resistentes a infestações de endo e ectoparasitas melhorando a sanidade geral do rebanho. Além disso, o PRV impulsiona o melhoramento das pastagens pela introdução de novas espécies através da sobressemeadura e, por último, favorece o uso de maior carga animal por área.

Corroborando com as afirmações anteriores, Machado (2003) afirma que esse sistema de produção resgata a intimidade entre o produtor, seus animais e a pastagem, considerando que o manejo dos animais de um piquete a outro é orientado pelo produtor, este responsável por decidir sobre qual dos piquetes está mais apto a receber os animais levando-se em conta o estagio de desenvolvimento das forragens. 
Este manejo é então realizado sem degradar os recursos naturais, proporcionando a recuperação progressiva da fertilidade do solo, entre outros benefícios, e contribuindo assim para a transição agroecológica, uma vez que, para o PRV ser instalado e manejado com sucesso é necessário se ater ao processo de transição que deve ocorrer, também, com a conscientização do agricultor, pois só assim as mudanças de atitudes irão sendo implantadas e a interação com a natureza passa a ser cada vez mais harmoniosa o que favorece o entendimento da Agroecologia e sua inserção no dia-a-dia dos agricultores.

\section{METODOLOGIA}

Com o propósito de verificar as contribuições do Pastoreio Racional Voisin na transição agroecológica e sustentabilidade da agricultura familiar no município de Santa Maria - RS realizou-se uma pesquisa descritiva de caráter exploratório em cinco propriedades de caracterização familiar. De acordo com Ribas e Fonseca (2008), este tipo de pesquisa é capaz de descrever a realidade da maneira que ela se apresenta, interpretando-a através da observação, do registro e da análise dos fenômenos. Sendo assim, procura responder indagações do tipo "o que acontece" na vida social, política e econômica, sem interferir nesta realidade.

O município de Santa Maria está localizado no centro-oeste geográfico do Estado do Rio Grande do Sul (RS) com uma população de 243.611 habitantes, 95\% destes residentes em zona urbana e apenas 5\% na zona rural, com a matriz econômica ancorada no cultivo de arroz, soja, milho, fumo e feijão preto, além da expressiva importância da bovinocultura de leite e de corte (IBGE, 2010).

Dentre os sistemas produtivos presentes no município destaca-se o trabalho de transição agroecológica em propriedades familiares a partir do uso do sistema do Pastoreio Racional Voisin (PRV), desenvolvido através da EMATER Municipal, desde 2011.

Para relato das experiências e considerações para a pesquisa, foram observados os seguintes elementos de análise: a) Tamanho da propriedade; b) Produção animal desenvolvida no sistema e forrageiras mais utilizadas; c) Composição familiar; d) Mão-de-obra (Quais os membros da família que se envolvem com a produção?); e) Ocorrência de sucessão familiar; f) Oportunidades de trabalho para a mulher; g) Relação ser humano/natureza através da ocorrência de fauna silvestre e do convívio dos agricultores com estes animais. Os dados foram coletados de agosto a novembro de 2016.

\section{RESULTADOS: AS PROPRIEDADES EM TRANSICÃ̃ AGROECOLÓGICA}

A Propriedade I possui 8,8 hectares de área total, com PRV instalado desde o ano de 2011, o sistema possui uma variedade de forrageiras, onde destaca-se, além do campo nativo da região, o tifton 85 (Cynodon sp.) e sobresemeadura de aveia (Avena sp.) e azevém (Lolium multiflorum) utilizadas no inverno. A família produz matrizes bovinas de corte com novilhas de raças adaptadas para produção de carne, mas ainda mantém alguns bovinos remanescentes da produção de leite, que antes era o carro chefe da família. Todos os animais dessa propriedade são medicados com homeopatia, por serem medicamentos "limpos", que não deixam resíduos nos alimentos e no ambiente. 
Imagem 1: Bovinos de corte em sistema de PRV: Propriedade I

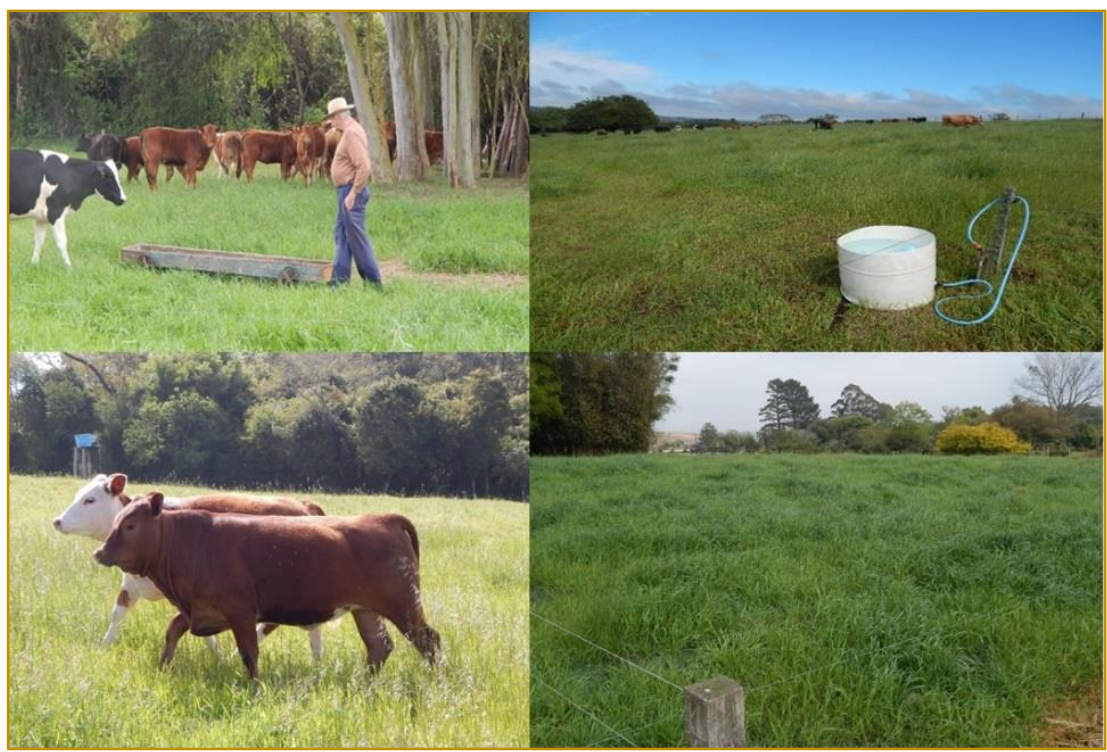

Fonte: Dados da Pesquisa, 2016.

A família é composta por um casal de agricultores aposentados. Não possuem mão-de-obra contratada, sendo eles mesmos responsáveis pela organização e gestão da propriedade. 0 casal possui dois filhos que moram em cidades distantes e, foi por falta de sucessão familiar que decidiram deixar a produção de leite para produzir matrizes de corte. A produção de leite exigia maior força de trabalho e por estarem sozinhos na propriedade optaram por migrar para a produção de matriz de corte que é menos trabalhoso e continua utilizando o PRV, instalando inicialmente para os bovinos de leite.

Em relação a ocorrência de fauna silvestre nesta propriedade observou-se uma variedade grande de avifauna vocalizando e forrageando na extensão dos piquetes, inclusive próximos a residência do casal. Além disso, notou-se a presença do besouro rola-bota em atividade na pastagem de PRV (Imagem 2). De acordo com o agricultor, várias vezes foi observado uma espécie de veado (Mazama sp.) forrageando nos piquetes junto com os animais domésticos, e o mesmo ocorre também com as seriemas (Cariama cristata). Com isso, percebe-se que há uma harmonia entre os seres humanos e os animais silvestres habitantes desse agroecossistema. Esse tipo de comportamento pode ser explicado pelo avanço no processo de transição agroecológica que se encontra essa propriedade.

Imagem 2: Fauna silvestre registrada em sistema de PRV na Propriedade I.

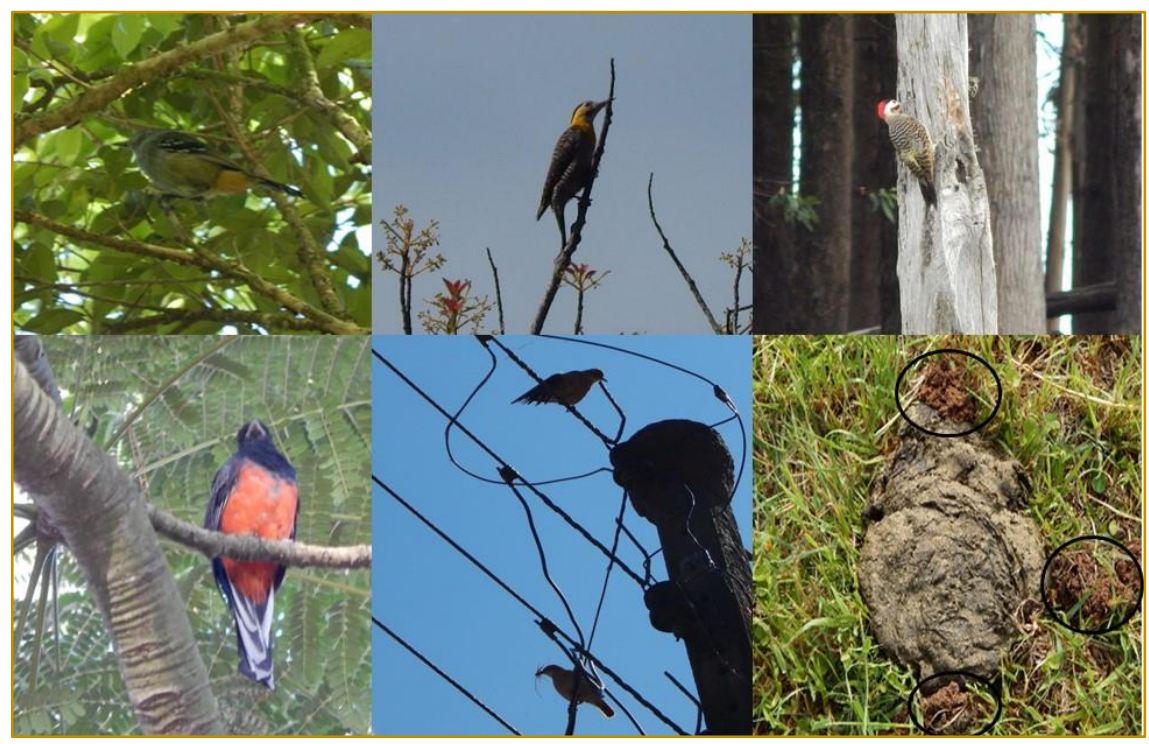

Fonte: Dados da Pesquisa, 2016. 
A Propriedade II possui 25 hectares de área total com PRV recém instalado no período da pesquisa de campo (2016). Por estar em fase de adequações, praticamente não havia sombra para os animais, pois as arvores recém tinham sido plantadas. No entanto, o sistema já estava sendo utilizado para alimentação dos bovinos leiteiros, pois já possuía massa de forragem suficiente para alimentar os animais sem degradar o agroecossistema (Imagem 3). Além do campo nativo no verão, as forrageiras mais utilizadas no sistema são a sobressemeadura de aveia (Avena sp.) e azevém (Lolium multiflorum) realizadas no inverno.

Imagem 03: Bovinos leiteiros em sistema de PRV e implantação de mudas de eucalipto para sombreamento: Propriedade II

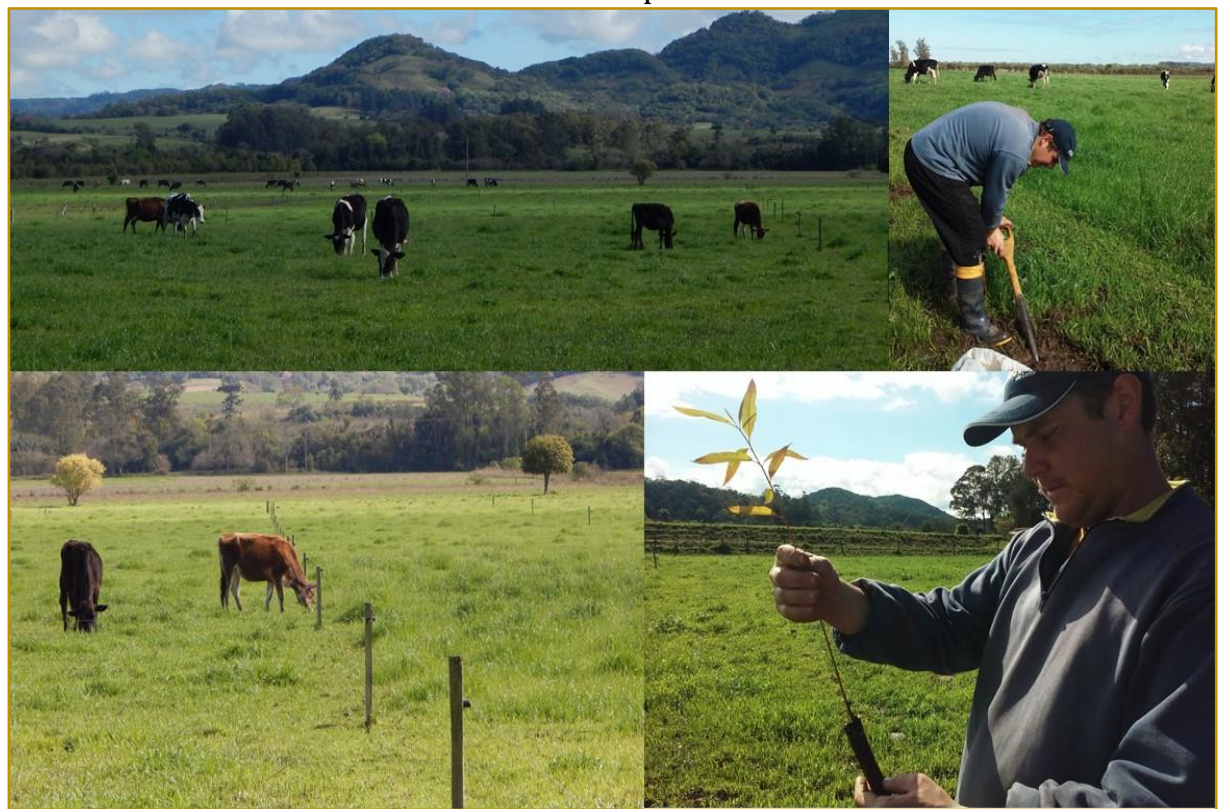

Fonte: Dados da Pesquisa, 2016.

Essa família começou a trabalhar com a produção de leite no ano de 2014, anteriormente trabalhavam com produção de arroz. A decisão de abandonar a lavoura se deu principalmente para evitar o manuseio de agrotóxicos. A propriedade está em fase de transição para o sistema de produção agroecológica, mas já se percebe bastante conscientização por parte dos agricultores, eles já utilizam homeopatia e alguns fitoterápicos no tratamento dos animais.

Nesta propriedade residem um casal de aposentados e um dos seus filhos com sua companheira. No entanto, é somente o jovem, filho do casal, que administra e organiza a propriedade juntamente com seu irmão mais velho, que já não mora mais com eles. São os dois irmãos que se envolvem mais com a produção, porém a mãe está sempre ajudando na ordenha e no trato dos animais. Mesmo com os outros integrantes da família se envolvendo em outras atividades, eles não precisam contratar mão-de-obra externa.

Quanto a ocorrência de animais silvestres na propriedade foram observadas Jaçanãs (Jacana jacana) agitadas próximo ao curral dos animais (Imagem 4). Como o PRV está instalado em uma área de várzea, favorece a presença dessas aves aquáticas, porém esse bando foi observado mais de uma vez no mesmo local. Esse tipo de atitude das Jaçanãs pode estar indicando a preparação para o momento da nidificação (construção dos ninhos para incubação dos ovos) que começa no mês de setembro e se estende até novembro, coincidindo com o período da pesquisa empírica. Essas aves, provavelmente, encontram um ambiente favorável para se reproduzirem na várzea cercada pelos piquetes do PRV, o que demostra que esse sistema colabora com a conservação das espécies silvestres nativas dos agroecossistemas, constituindo ainda indicador positivo na relação ser humano/natureza. 
Imagem 4: Jaçanãs na área de várzea em sistema de PRV.

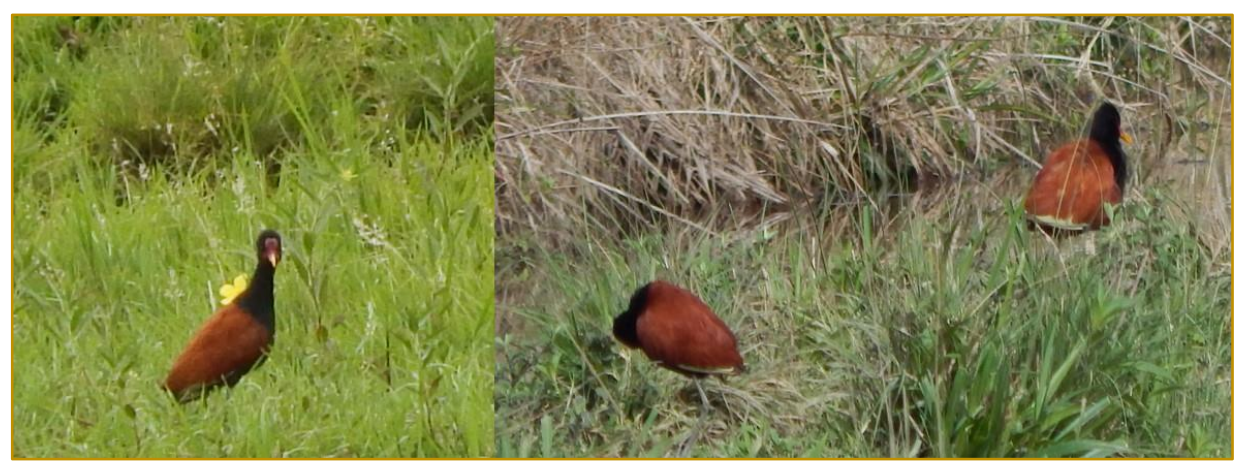

Fonte: Dados da Pesquisa, 2016.

A Propriedade III possui 8 hectares de área total, onde o sistema de PRV recém havia sido instalado, porém, assim como na propriedade anterior, já estava sendo utilizado para a alimentação dos bovinos leiteiros. Mesmo recém implantado, já possuía sombra e massa de forragem para alimentar os animais nos piquetes (Imagem 5). As forrageiras mais utilizadas neste sistema eram a vegetação nativa e a sobressemeadura de aveia (Avena sp.) e azevém (Lolium multiflorum) para o inverno.

Imagem 5: Bovinos de leite em sistema de PRV : Propriedade III

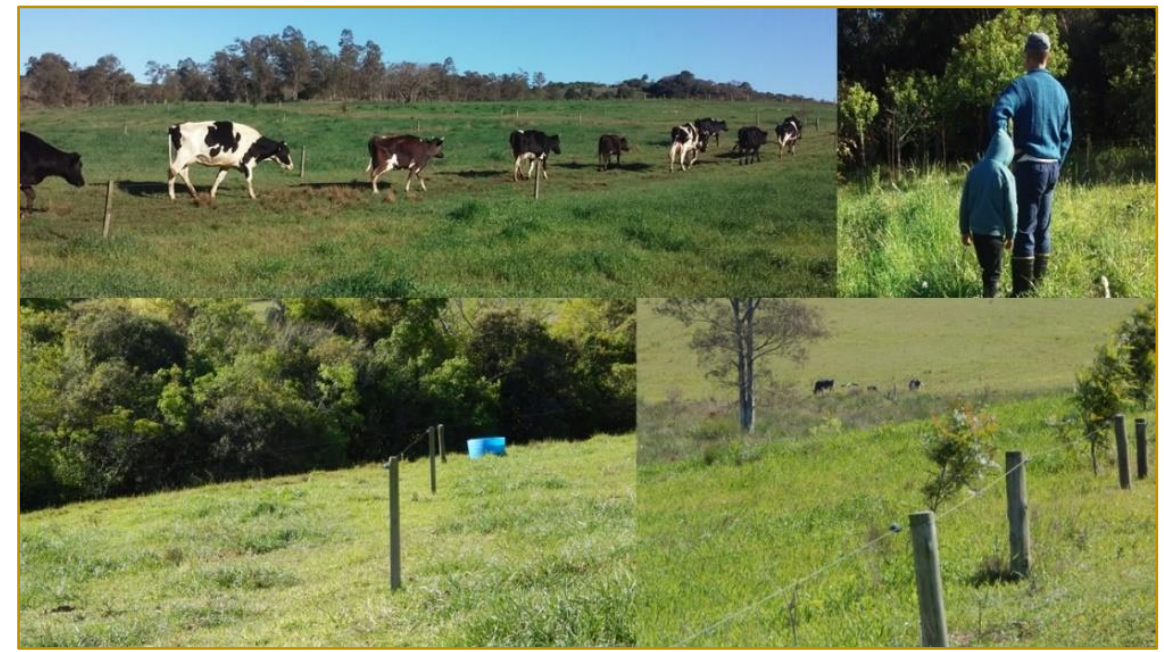

Fonte: Dados da Pesquisa, 2016.

Quanto ao manejo do plantio das forrageiras, essa propriedade demonstra estar no processo inicial de transição agroecológica. A adubação química industrial ainda ocorre, bem como o uso de grades de disco para movimentação do solo antes da semeadura de aveia e azevém. Contudo, o produtor se mostra feliz com a produção de leite, pois antes produzia arroz e optou por abandonar a lavoura para não trabalhar mais com agrotóxicos e ensinar seu filho a trabalhar com algo que não prejudique a saúde.

Nesta propriedade residem um casal com seu filho mais jovem (a filha mais velha já não reside na propriedade). 0 responsável pelas atividades e gestão da propriedade é o agricultor que não contrata mão-de-obra de fora, por considerar sua produção pequena. A esposa do agricultor trabalha fora da propriedade. Em relação a sucessão familiar, o casal tem expectativa que o filho, ainda pequeno possa ser o sucessor nas atividades, neste sentido o menino recebe incentivos do Pai a partir de aproximações no manejo com os animais e a natureza.

Em relação a ocorrência de animais silvestres na propriedade, observou-se a presença abundante da avifauna comum da região Sul, como o quero-quero (Vanellus chilensis), João-de-barro (Furnarius rufus), tico-tico (Zonotrichia capensis), entre outros (Imagem 6). Em razão da propriedade recém estar passando pelo processo inicial de transição agroecológica, não houve relato e nem registros de animais menos 
comuns no estado, porém percebe-se que o sistema de PRV já favoreceu visivelmente a biodiversidade local.

\section{Imagem 6: Fauna silvestre registrada em sistema de PRV: Propriedade III}

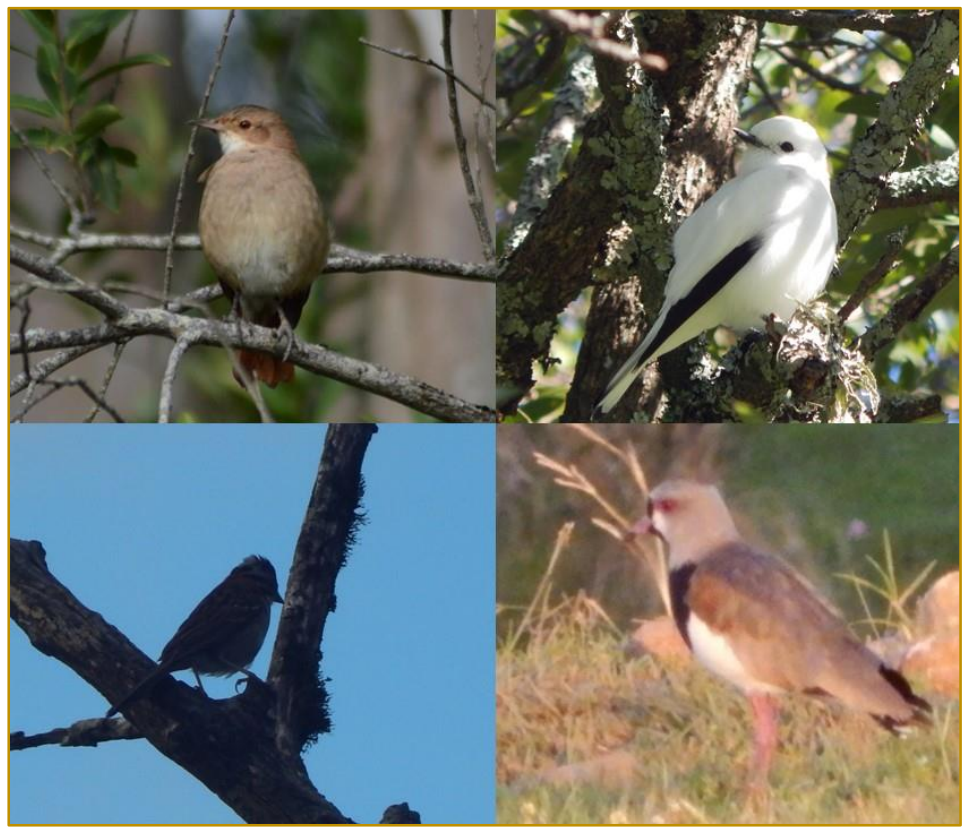

Fonte: Dados da Pesquisa, 2016.

A Propriedade IV possui 12 hectares de área total e é parte integrante do assentamento Carlos Marighella. Esse sistema de PRV estava em fase de adequações, pois não havia disponibilidade de água em todos os piquetes e a sombra ainda era pequena, pois as árvores recém estavam se desenvolvendo. Porém, assim como nas outras propriedades, o agricultor já estava utilizando o sistema para a alimentação dos bovinos leiteiros, pois consegue manejar com muita eficiência as forrageiras ali presentes (Imagem 7).

Imagem 7: Bovinos leiteiros em sistema de PRV com pastagem sendo recuperada: Propriedade IV

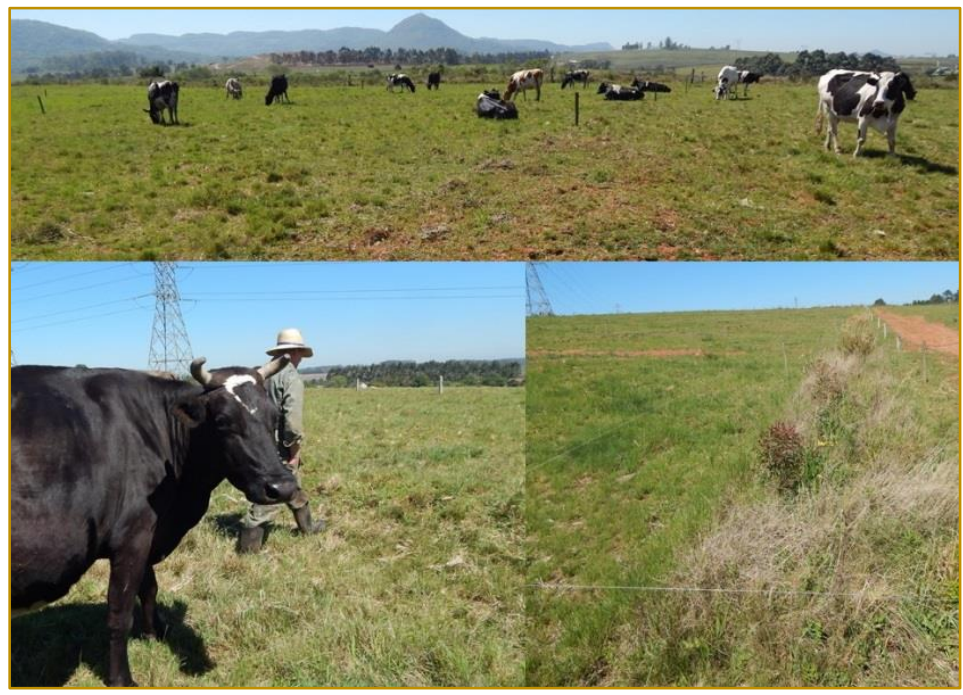

Fonte: Dados da Pesquisa, 2016. 
A forrageira com maior expressividade nos piquetes dessa propriedade é o agressivo capim annoni (Eragrostis plana), além do campo nativo. 0 controle dessa gramínea invasora requer muito conhecimento e experiência, o que parece não faltar para esse agricultor. De acordo com as afirmações deste, que possui conhecimento sobre a agroecologia, a técnica de dessecamento e revolvimento do solo só piora a infestação do annoni. Essas técnicas são comumente usadas no controle do capim-annoni em sistemas convencionais, mas acabam causando o efeito contrário.

Segundo Boldrini (2005) o capim annoni é uma gramínea de alta rusticidade, com sistema radicular agressivo e pouco exigente com a fertilidade do solo, o que corrobora com a fala do agricultor, pois ao dessecarmos a área a microbiologia do solo será praticamente destruída e com isso a fertilidade do mesmo também será muito prejudicada. Então, quanto mais pobre em nutrientes for o solo, com mais vigor essa gramínea se espalhará por não sofrer o problema de competição com outras espécies mais exigentes. Esse fato deixa claro que o uso de agrotóxico só aumenta o problema.

O agricultor afirmou que chegou a revolver o solo algumas vezes e que esse manejo também ajuda na proliferação do annoni, pois ao fazer o revolvimento do solo trazemos a superfície as sementes desta gramínea que estavam soterradas em estado de dormência, e novamente o processo inverso ocorrerá. De acordo com as experiências práticas do agricultor, o controle do capim anonni deve ser feito com roçada e adubação orgânica da pastagem, pois ao roçar os piquetes de PRV, além de estar adubando com a palhada, também estará "sufocando" a gramínea e impedindo o seu desenvolvimento.

Ao roçar e fazer adubação orgânica na área ele disponibiliza substrato para os microrganismos fazerem o seu trabalho, e assim aumenta significativamente a fertilidade do solo. Com isso, outras plantas nativas vão crescendo e se desenvolvendo nos piquetes, competindo diretamente com o annoni que aos poucos vai sendo eliminando da pastagem.

Nesta propriedade residem um casal, seu filho jovem com uma companheira e uma criança, filho dos dois. 0 jovem trabalha na produção com os pais e recebe incentivo para realizar o manejo com os animais. Todos os moradores dessa propriedade estão envolvidos com a produção e comercialização dos produtos.

Quanto a presença de animais silvestres nesta propriedade observou-se uma variedade de avifauna vocalizando e forrageando aos arredores dos piquetes, como a garça-vaqueira (Bubulcus íbis) que tem um importante papel no controle biológico de carrapatos e outros insetos parasitos (Imagem 8). Além disso, em uma visita na propriedade notou-se um episódio não muito frequente, três saracuras-do-mato (Aramides saracura) em um ritual de acasalamento, onde provavelmente, dois machos estavam disputando uma fêmea. Com isso, assim como nas propriedades anteriores, o PRV tem demonstrado contribuir significativamente com a conservação das espécies silvestres nativas dos agroecossistemas.

Imagem 8: Fauna silvestre registrada em sistema de PRV: Propriedade IV

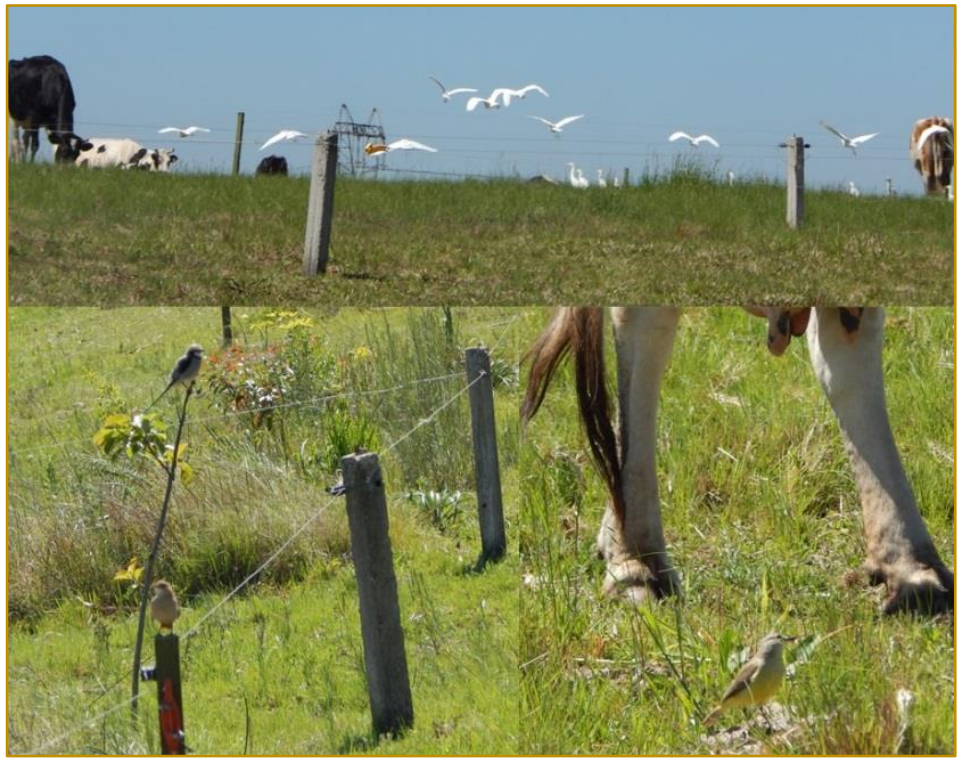

Fonte: Dados da Pesquisa, 2016. 
A Propriedade V possui 40 hectares de área total com o sistema de PRV instalado desde de 2011. Nesta propriedade a principal fonte de renda é oriunda da produção de leite e as forrageiras utilizadas no PRV para alimentação dos animais são diversas, porém as que mais se destacam são a vegetação nativa da região, o capim-aruana (Panicum maximum), a grama missioneira (Axonopus compressus) e a sobresemeadura de azevém (Lolium multiflorum) utilizado no inverno (Imagem 9). Os animais recebem doses diárias de homeopatia para controle de mastite, mamite e endo e ectoparasitas.

Imagem 9: Bovinos leiteiro em sistema de PRV: Propriedade V

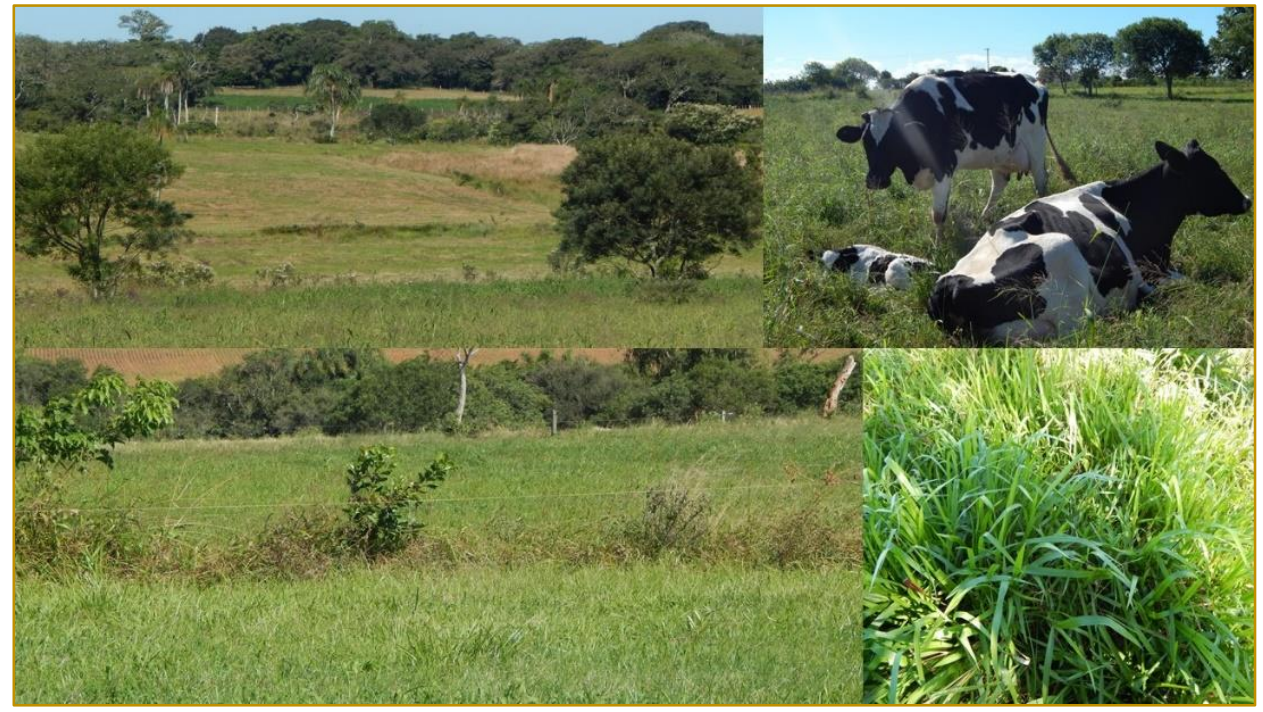

Fonte: Dados da Pesquisa, 2016.

Nesta propriedade residem um casal, seu filho mais jovem e um irmão do agricultor proprietário. Todos os moradores da propriedade se envolvem com as atividades desenvolvidas no local, com isso, não necessitam contratar mão-de-obra. A mulher da propriedade prefere não se envolver com a produção leiteira e passa ser responsável por outras tarefas, como a comercialização de noz pecã (Carya illinoinensis). As nogueiras pecã foram plantadas com o objetivo principal de proporcionar sombra para os animais nos piquetes de PRV e agora já estão proporcionando renda para a família.

Quanto a sucessão familiar, nessa propriedade o filho mais jovem do casal optou em abandonar um curso técnico e voltar para casa produzir leite que sempre foi a tradição da família. Entretanto, o jovem buscou inovar e com o aceite do pai, implantaram o PRV que tem aumentado a renda da família significativamente.

Em relação a presença de fauna silvestre na propriedade observou-se uma grande variedade de avifauna vocalizando e forrageando aos arredores dos piquetes. Dentre estas aves registrou-se um bando de seriemas (Cariama cristata) e outras aves típicas de ambientes abertos (campo) (Imagem 10). Além das aves, notou-se a presença do besouro rola-bosta em constante atividade nos piquetes e a ocorrência de alguns buracos (Imagem 10) feitos por um pequeno mamífero campestre de hábitos noturnos em busca de alimentos, o zorrilho (Conepatus chinga), comumente encontrado nessa região. Toda essa biodiversidade é um indicador claro da sustentabilidade ambiental promovida pelo PRV, que quanto mais equilibrado estiver no agroecossistema, maior será o seu potencial na conservação ambiental. 
Imagem 10: Fauna silvestre registrada em sistema de PRV: Propriedade V

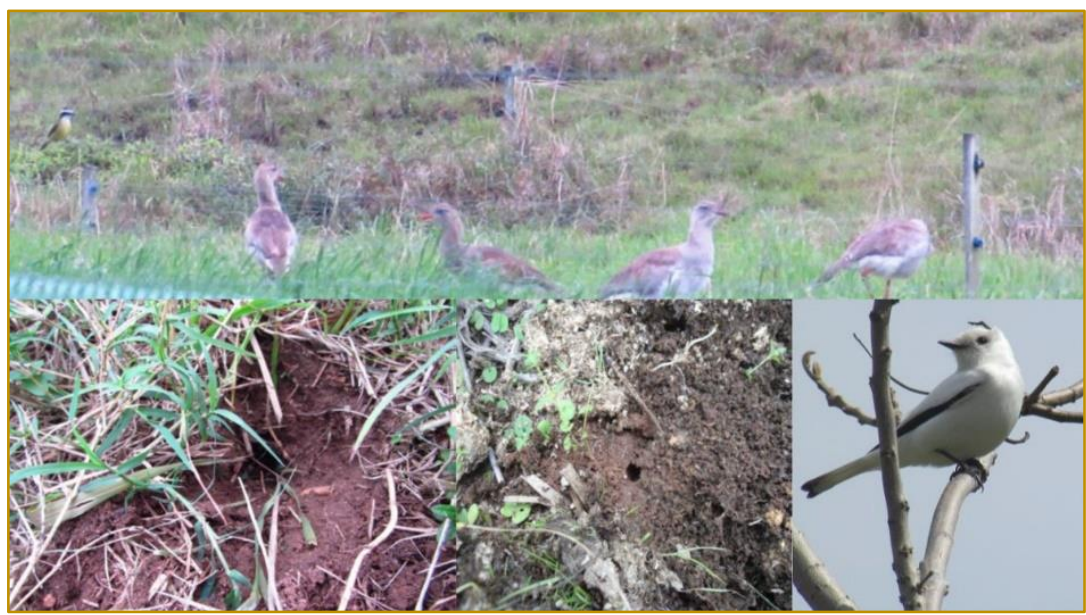

Fonte: Dados da pesquisa, 2016.

\section{DISCUSSÃO DOS RESULTADOS E CONSIDERAÇÕES FINAIS}

Com base nos resultados apresentados percebe-se que o Pastoreio Racional Voisin pode ser considerado um potencializador da Agroecologia em propriedades de agricultores familiares, onde área e mão-de-obra costumam ser limitantes. As experiências estudadas apontam indicadores de transição agroecológica e sustentabilidade que vêm permitindo, além de ganhos na produtividade, conservação dos recursos naturais e relações positivas ser humano/natureza.

Com relação à produção, constata-se que as Leis fundamentais do PRV, descritas por Pinheiro Machado, estão sendo respeitadas em todas as propriedades. Com isso, os processos de degradação do solo e das pastagens estão sendo reduzidos, a preservação ambiental está ocorrendo e o bem-estar animal está sendo alcançado, considerando que o tempo de implantação do PRV é diferente entre as propriedades e que portanto o cumprimento às Leis Fundamentais apresentam-se em estágios diferentes entre as 5 propriedades.

No quesito manejo ecológico destaca-se o uso da sobressemeadura como manejo agroecológico, sem revolver solo e promover erosão, uso da homeopatia animal em substituição aos medicamentos industriais, o que acaba por promover maior autonomia aos agricultores para controle de pragas e doença. Também se destaca como manejo ecológico a prática de adubação orgânica promovida pelo esterco dos animais como fertilizantes naturais. Isso é facilitado pela estada controlada dos animais em cada um dos piquetes e o tempo de repouso no uso de cada um, o que permite acúmulo de esterco e tempo de fermentação adequada para inativar os microrganismos patogênicos e o risco de contaminação.

Por consequência, a produtividade vem sendo favorecida proporcionando melhoras na renda das famílias, contribuindo assim para a diminuição do êxodo seletivo, caraterizado pelo abandono do campo, por mulheres e jovens. As experiências apresentadas relatam casos de sucessão familiar proporcionados pelas oportunidades de trabalho e renda para os membros das famílias e ainda diminuição das penosidades do trabalho, estas propiciadas pela facilidade no trato com os animais que sem condições de estresse apresentam-se mansos e dóceis no manejo, facilitando ainda o trabalho das mulheres nas atividades agropecuárias.

Destaca-se que as mulheres possuem certo protagonismo em todas as propriedades, mesmo que nem todas estejam envolvidas diretamente com as atividades agrícolas ligadas ao PRV. De acordo com as 5 propriedades descritas, somente em uma delas a mulher desenvolve funções fora da propriedade, nas demais, todas estão presentes com participação ativa na produção, organização e gestão das propriedades.

Quanto às questões de qualidade de vida, os agricultores relatam mais facilidades no trato com os animais garantido pelo bem-estar animal e divisão da área em piquetes. Os animais apresentam-se mansos e livres de doenças, graças a alimentação abundante, ausência ou diminuição de estresse e ainda uso racional dos piquetes, o que permite aos animais estarem menos susceptíveis a infestações de endo e ectoparasitas uma vez que a rotatividade nos piquetes não permite que os parasitas completem seus ciclos reprodutivos nos animais. 
Em relação a ocorrência de fauna silvestre é evidente as vantagens nas 5 propriedades, pois em todas destacou-se a variedade de avifauna silvestre forrageando e se reproduzindo na extensão dos piquetes de PRV. Ainda se registrou a presença do besouro rola-bosta em atividade nas duas propriedades que estão como o PRV instalado a mais tempo indicando assim, incorporação de matéria orgânica no solo e reforçando a importância do PRV na recuperação da fertilidade dos solos.

Além disso, um dos agricultores relatou a presença de um herbívoro silvestre forrageando com os animais domésticos nos piquetes e houve um registro da evidência da presença de um mamífero noturno em uma das propriedades. Assim sendo, a relação ser humano/natureza vem se mostrando harmoniosa em todas as propriedades.

Por fim destaca-se o Pastoreio Racional Voisin como importante potencializador dos processos de transição agroecológica na agricultura familiar, onde os desafios do desenvolvimento rural podem encontrar suporte.

\section{REFERÊNCIAS}

[1] Altieri, M. Agroecologia: a dinâmica produtiva da agricultura sustentável. 4. ed. Porto Alegre: UFRGS, 2004.

[2] Boldrini, I. I.; Longhi-Wagner, H. M.; Boechat, S. D. Morfologia e taxonomia de gramíneas Sul-RioGrandenses. Porto Alegre: Universidade Federal do Rio Grande do Sul, 2005. p. 45-47

[3] Brasil. Lei 11.326/2006. Diário Oficial da União, Brasília, DF, 24 jul. 2006. Disponível em: <http://www.planalto.gov.br/ ccivil_03/_ato 2004-2006/.../lei/l11326.htm>. Acesso em: 20 abril. 2017.

[4] Caporal, F. R.; Costabeber, J. A. Agroecologia e extensão rural: contribuições para a promoção do desenvolvimento rural sustentável. Brasília: MDA/SAF/DATER-IICA, 2004. Disponível em: <http://www.emater.tche.br/site/arquivos_pdf/teses/agroecologiaeextensaoruralcontribuicoesparaapromocaodede senvolvimentoruralsustentavel.pdf $>$. Acesso em: 19 mar. 2017

[5] Costabeber, J. A. Acción colectiva y procesos de transición agroecológica en Rio Grande do Sul, Brasil. Córdoba, 1998. (Tese de Doutorado) Programa de Doctorado en Agroecología, Campesinado e Historia, ISEC-ETSIAN, Universidad de Córdoba, España, 1998. 422p.

[6] França, C. G. de; Grossi, M. E. Del; Marques, V. P. M. de A. O censo agropecuário 2006 e a agricultura familiar no Brasil. Brasília: MDA $2009 . \quad$ Disponível <http://www.bb.com.br/docs/pub/siteEsp/agro/dwn/CensoAgropecuario.pdf>. Acesso em: 19 mar. 2017.

[7] Ferrari, E. A. Agricultura familiar camponesa: estratégias de reprodução socioeconômica e a contribuição da agroecologia. 2010. 136f. Dissertação (Mestrado em Extensão Rural) - Universidade Federal de Viçosa, Viçosa.

[8] Herrera, A. R.; Ugarte, H. A. Claves de la innovación social em América Latina y el Caribe. Santiago do Chile: Cepal, $2008 . \quad$ Disponível em: <http://repositorio.cepal.org/bitstream/handle/11362/2536/S0800540_es.pdf;jsessionid=1F4DE31E20E40A38993 F88B04CC83802? sequence=1>. Acesso em: 20 maio 2017.

[9] Instituto Brasileiro de Geografia e Estatística, Censo Demográfico, 2010. Disponível em: <http://www.cidades.ibge.gov.br/xtras/perfil.php?lang=\&codmun=431690\&search=rio-grande-do-sul|santa-maria>. Acesso em: 26 mar. 2017.

[10] Machado, L. C. P. Pastoreio Racional Voisin: projeto 214: Fazenda Margarida. Florianópolis: UFSC, Centro de Ciências Agrárias, 2003. 153 p.

[11] Pinheiro Machado, L. C. Pastoreio Racional Voisin: tecnologia agroecológica para o 3. milênio. São Paulo: Expressão Popular, 2010.

[12] Ribas, C. C. C.; Fonseca, R. C. V. Manual de metodologia. Curitiba: OPET, 2008. Disponível em: <http://www.opet.com.br/biblioteca/PDF's/Manual_DE_MET_Jun_2011.pdf> Acesso em: 25 mai. 2017. 


\section{Paṕlitulo 3}

\section{ROMPENDO A INVISIBILIDADE POLITICA DA AGRICULTURA FAMILIAR DE QUEIMADOS-RJ}

\section{Jaime Rodrigo da Silva Miranda \\ Camila Cristina Nascimento Da Silva \\ Bruno Tadeu Lopes}

Resumo: Este relato discute o projeto que visa dar visibilidade política aos(as) agricultores de Queimados-RJ junto à Prefeitura, que não define em seu Plano Diretor a zona rural. A equipe da Universidade Federal Rural do Rio de Janeiro vem fazendo um levantamento sócio-econômico e ambiental com as famílias, de lote em lote, identificando o público produtor para fomentar ações que o beneficie. A imprecisão de informações dificulta seu acesso a políticas públicas de cunho agroecológico, como Extensão Rural e Mercados Institucionais. O meio rural é composto por um assentamento e outras cinco localidades, tendo-se agricultores agroecológicos comercializando no entorno. Uma projeção de expansão do distrito industrial de Queimados para a área do assentamento vem desestimulando moradores a investirem em seus lotes diante das incertezas de permanência no local, fazendo com que a equipe realize também trabalho educativo quanto a direitos e deveres de residentes em áreas de reforma agrária. 


\section{CONTEXTO}

O município de Queimados-RJ se localiza na região da Baixada Fluminense e possui aproximadamente 145.000 habitantes. Segundo o site de consultas sobre mercado deepAsk, apresenta como principal fonte de receitas o setor de serviços (45,5\% do PIB), seguido da indústria (21,3\%), arrecadação de impostos $(14,6 \%)$, estando o setor agropecuário em quarto e último lugar na arrecadação com 4,5\% do total (www.deepask.com, 2017)

Dois aspectos contribuem para que a fragilidade econômica em que se encontra a agropecuária se agrave. 0 primeiro é que, conforme encontros entre os autores deste relato e técnicos da Secretaria Municipal de Desenvolvimento Rural e Agricultura (SEMDRAG), não estão sistematizadas por parte do poder público informações precisas sobre a realidade sócio-econômica e ambiental de sua zona rural, intensificando a invisibilidade política dos(as) agricultores(as) familiares, comprometendo assim o atendimento de suas demandas. 0 segundo aspecto consiste numa projeção de expansão do Distrito Industrial de Queimados para dentro da área do Assentamento Fazendinha, incentivada em 2011 pelo governo estadual. A imagem a seguir obtida do site oficial da Associação das Empresas do Distrito Industrial de Queimados (ASPINQ) em 04 de abril de 2017 revela a proposta do avanço: a linha branca representa o perímetro atual da área das indústrias; a linha azul representa o perímetro projetado para a expansão que abrange a área do assentamento (onde lê-se "Expansão D.I."). Esta situação vem gerando instabilidade fundiária, evasão e insegurança dos(as) moradores quanto às possibilidades de permanecerem em seus lotes, mediante especulação imobiliária, pressão externa para venda das terras, dúvidas quanto à legalidade do processo.

Figura: Imagem da Projeção de Expansão do Parque Industrial de Queimados-RJ

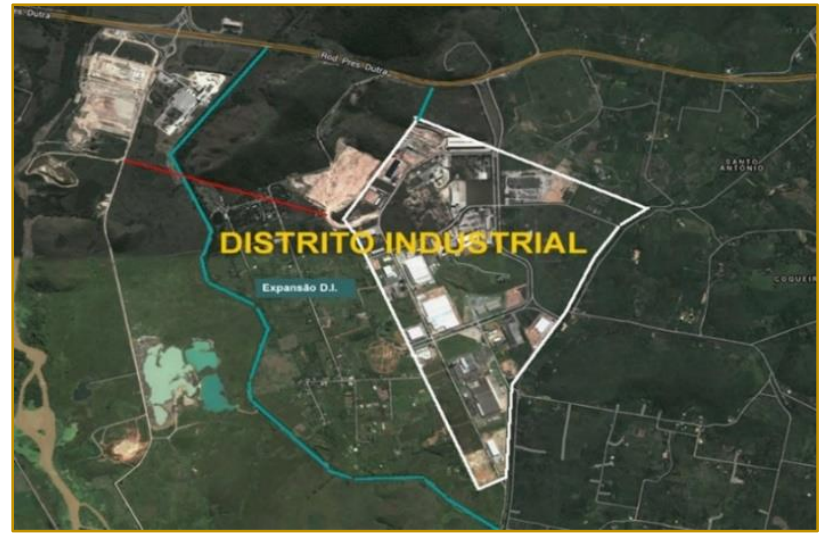

Fonte: site oficial da ASPINQ, 2017.

Ressalta-se que não se obteve fontes que apresentem mapa com definição da área do assentamento. Contudo, pelo conhecimento empírico dos assentados(as), dos técnicos da Prefeitura, da equipe da UFRRJ e por meio da ampliação da imagem, garante-se que a área delimitada pela linha azul coincide com área da Fazendinha, conforme os indicativos de estradas, construções e outros.

Diante desse contexto, vem sendo realizado desde agosto de 2016 o projeto intitulado Rompendo a Invisibilidade Política da Agricultura Familiar de Queimados-RJ, através da parceria entre dois estudantes de Agronomia, um professor da área Extensão Rural da UFRRJ e moradores da zona rural. 0 trabalho consiste em, primeiramente, realizar um levantamento sobre a realidade do meio rural do município. Estão sendo identificadas as famílias produtoras e as famílias não produtoras, evidenciando-se o potencial produtivo, demandas e limitações encontradas. Estas informações serão apresentadas e discutidas junto ao governo a fim de que políticas públicas e medidas ainda ausentes sejam implementadas, fortalecendo a agricultura familiar na região.

O meio rural é composto pelo assentamento Fazendinha - sob jurisdição do Instituto de Terras e Cartografia do Estado do Rio de Janeiro (ITERJ) com cerca de 80 lotes - e outras cinco localidades chamadas Vila Americana, Capoeirão, Chapadão, Vista Alegre e Vilar Grande.

Parte das famílias tem nas atividades agropecuárias seu principal meio de trabalho e geração de renda. Dentre estas, algumas desenvolvem manejos de área nativa, atividades agrícolas e criação animal com uso de princípios agroecológicos. Como exemplo, em um sítio visitado em trabalho de campo, parte do lote é coberta por mata secundária destinada à preservação permanente e parte apresenta cultivos de frutas, 
hortaliças e aves de criação destinadas ao consumo e venda, com irrigação manual das plantas sem uso de agrotóxicos e adubos químicos, mão de obra totalmente familiar e algum nível de beneficiamento dos produtos vendidos no entorno. Há processos de intervenção e ações realizadas pela Secretaria junto às localidades, tendo sido realizado um levantamento empírico pelos técnicos da Prefeitura, estimando-se cerca de 350 estabelecimentos, sendo 250 produtores. Destes, 30 agricultores agroecológicos estão inscritos na Feira da Roça de Queimados.

Existem lotes com produção e morada habitual da família e lotes sem produção agropecuária, frequentados pelos proprietários residentes no setor urbano apenas nos fins de semana. Ao fim do levantamento, espera-se ter a quantificação e mapeamento dos estabelecimentos produtivos e não produtivos.

Tanto os assentados(as) quanto as demais populações recebem de forma não regular serviços de Extensão Rural através da Empresa de Assistência Técnica e Extensão Rural (EMATER) da cidade vizinha Nova Iguaçu, cuja grande demanda de trabalho inviabiliza um atendimento na qualidade e quantidade suficiente para Queimados, que não dispõe de uma unidade da empresa. Não se tem ainda registros de acesso a mercados institucionais como a Política Nacional de Alimentação Escolar (PNAE) e o Programa de Aquisição de Alimentos (PAA), nem acesso a linhas de crédito do Programa Nacional de Fortalecimento da Agricultura Familiar (PRONAF).

\section{DESCRIÇÃO DA EXPERIÊNCIA}

O projeto se iniciou por iniciativa dos estudantes que, sendo moradores de Queimados, se interessaram em conhecerem mais profundamente sua realidade rural. Sabendo que em 2016 a Secretaria Estadual da Fazenda questionou a Prefeitura de Queimados por estar recebendo pagamento do Imposto Territorial Rural (ITR) sem, no entanto, ter claramente identificada e caracterizada a zona rural da cidade em seu Plano Diretor, os graduandos fizeram os primeiros contatos com as comunidades e com a SEMDRAG, propondo fazer o levantamento. Buscaram contato e orientação do professor que, tendo sido Extensionista Rural por anos em áreas de reforma agrária, logo se envolveu com as propostas e sugeriu a transformação das idéias em um projeto registrado na UFRRJ.

Em síntese, assim se organiza a metodologia do trabalho:

a ) sistematização das informações obtidas pelos estudantes no período anterior ao início da parceria com o professor; b) busca e sistematização de informações sobre a zona rural de Queimados; c) cadastramento do projeto na Pró-Reitoria de Extensão da UFRRJ; d) elaboração de um questionário com questões sobre as situações sociais, econômicas, técnico-produtivas, ambientais e políticas das famílias e da comunidade; e) realização de visitas da equipe do projeto às localidades para apresentação e discussão do projeto, conhecendo assim o contexto e a realidade local; f) visitas da equipe aos lotes para apresentação do projeto e aplicação do questionário; g) elaboração de relatórios de atividades, sistematização e digitalização dos questionários; h) reuniões com representantes de instituições públicas. i) esclarecimentos sobre procedimentos técnico-administrativos envolvidos em um projeto de assentamento junto aos/as assentados/as.

O trabalho se encontra na etapa "f", tendo ocorrido visita e aplicação de questionários a 32 famílias do assentamento Fazendinha - primeira localidade escolhida para o levantamento, partindo-se do contato prévio com representantes da associação local que apoiou o projeto e acompanha as atividades. Pretendese visitar todos os lotes da zona rural da cidade, a fim de se fazer um levantamento preciso. Ressalta-se que na Fazendinha, por se tratar de área de reforma agrária, a equipe vem tendo o desafio de responder dúvidas e questionamentos quanto a direitos e deveres envolvendo a comunidade e o poder público, frente a proposta de expansão do distrito industrial.

A relação com a Prefeitura é amistosa, estando a SEMDRAG a favor do projeto, ciente das informações a serem obtidas e das possibilidades de intervenção que dele venham decorrer. A Secretaria disponibilizou sala, computador e impressora para apoio.

Diante do que já foi realizado, alguns resultados já podem ser evidenciados. 


\section{RESULTADOS E DISCUSSÃO}

Pôde-se verificar até o momento um grande potencial agrícola na área da Fazendinha, sem nenhuma restrição físico-climática mais severa para os cultivos, tendo-se disponibilidade de água no subsolo a poucos metros de profundidade e afluentes do rio Guandu que cortam a região. A comercialização é facilitada pela proximidade às cidades de Queimados, Nova Iguaçu e Duque de Caxias, estando as estradas em boas condições. A presença de 30 famílias inscritas na Feira da Roça, além de outras identificadas em visitas, indica o potencial agroecológico já existente e a ser trabalhado. Produtores(as) do assentamento já discutiram com a equipe seu interesse em formar um grupo de Sistema de Participação Garantida (SPG) para viabilizar a certificação orgânica de seus produtos.

A presença da equipe vem possibilitando maior compreensão dos moradores(as) quanto às questões técnico-administrativas no assentamento, incentivando a associação a se organizar, a atualizar a documentação que lhe cabe e buscar junto ao ITERJ informações quanto ao cumprimento de suas obrigações para com a comunidade. Faz-se notória, nas visitas de campo, a carência de informações sobre direitos e deveres das famílias como residentes de um assentamento rural. A equipe vem tratando de assuntos como: aquisição de documentos como Declaração de Aptidão ao PRONAF (DAP); Mercados Institucionais acessíveis (a UFRRJ está envolvida no Programa de Aquisição de Alimentos para o restaurante universitário); medidas governamentais em vigor como a MP 759 aprovada que altera relações do Estado com assentamentos; a polêmica proposta de expansão do distrito industrial para dentro de uma área gerida por órgão público; questões técnicas sobre criação animal e cultivos. Já foram debatidas possíveis parcerias com outros colegas da UFRRJ para promoção de cursos de capacitação técnica de interesse das famílias.

\section{CONCLUSÃO}

Os trabalhos e o levantamento feitos até então permitem a identificação de áreas com potencial produtivo - incluindo lotes com sistemas agroecológicos - e áreas não produtivas na primeira das seis localidades, já podendo-se vislumbrar ações e projetos de intervenção para fortalecimento da agricultura familiar. Sem estarem identificados oficialmente, os(as) agricultores(as) se tornam muito pouco visíveis politicamente, comprometendo o acesso a uma série de benefício que dependem de etapas burocráticas para sua realização, incluindo políticas com foco em adoção de princípios agroecológicos.

Um maior envolvimento da universidade na solução dos problemas agrários do seu entorno é observado neste trabalho que busca integrar pesquisa e extensão, num momento acadêmico em que mais a pesquisa e menos a extensão vem sendo priorizada no âmbito do "tripé Ensino-Pesquisa-Extensão". Ademais, o trabalho junto às famílias de lote a lote está favorecendo maior compreensão dos(as) moradores quanto à conjuntura política em que estão inseridos, a fim de buscarem atendimento às suas demandas num contexto de adversidades históricas enfrentadas pela agricultura familiar fluminense, agravada pela séria crise financeira do estado.

\section{AGRADECIMENTOS}

Agradecemos o Sr. Osvaldo e o Sr. Roberto, ex e atual presidente da Associação dos Camponeses e Produtores da Fazendinha, pela recepção e parceria no projeto.

\section{REFERÊNCIAS}

[1] Produto Interno Bruto. Disponível em < www.deepask.com>. Acesso em 07 de abril de 2017.

[2] Mapa do Distrito. Disponível em <www.asdinq.org.br>. Acesso em 04 de abril de 2017. 


\section{Bapítulo 4}

O AVANÇO DAS LAVOURAS DE SOJA NA AMAZÔNIA MATOGROSSENSE: PREOCUPAÇÃO OU DESENVOLVIMENTO?

Jôine Cariele Evangelista do Vale

Luany Alves Galvão

Rosimara Barboza Bispo

Rosimeire Barboza Bispo

Vera Lúcia Pegorini Rocha

Rosália do Nascimento da Silva

Marla Leci Weihs

Eduardo Darvin Ramos da Silva

Resumo: Alta Floresta pertence à região norte do Estado de Mato grosso, no conhecido "Arco do Desmatamento". Em menos de 40 anos, o município teve mais de 50\% de vegetação nativa convertida em áreas destinadas principalmente à pecuária. Recentemente, a implantação da sojicultora tem se expandido na região, substituindo, sobretudo, áreas de pastagem. Este trabalho objetiva conhecer os possíveis impactos socioambientais gerados pela chegada da monocultura da soja. Realizou-se entrevistas com cinco pessoas cuidadosamente selecionadas pelo seu envolvimento com a questão. Os resultados apontam preocupações no âmbito ambiental e social. A expansão da soja aumentará gastos com saúde pública, já que o uso de agrotóxicos irá causar contaminação da água e do solo, afetando, em última instância, a saúde da população. Conclui-se que a conversão de áreas de floresta nativa em áreas de uso agropecuário ameaça não só a biodiversidade, mas também os serviços essenciais que ela proporciona à população humana.

Palavras-chave: monocultura; soja; biodiversidade; manejo; 


\section{INTRODUÇ̃̃O}

De acordo com Barbosa \& Assumpção (2001), a soja foi uma das culturas que na segunda metade do século XX apresentou maior crescimento no cultivo e no âmbito agroindustrial e esse é o principal motivo de sua importância econômica para o País. Na região Centro Oeste, o aumento da produção da soja e do gado se deu devido à depreciação econômica ocorrida principalmente nos anos 1990, no Estado de Mato Grosso (BRANDÃO et al., 2005). A safra estimada de grãos no país em 2016/2017 alcançou a marca histórica de aproximadamente 232 milhões de toneladas, das quais a soja teve um crescimento de 15,4\% na produção, um aumento de $14,7 \%$ de toneladas em relação a safras anteriores, com ampliação de 1,4\% na área, aproximadamente 33,7 milhões de hectares (BRASIL, 2017).

A substituição de áreas de floresta nativa em áreas de uso agropecuário ameaça não só a biodiversidade, mas também os serviços essenciais que ela proporciona a população humana (WWF, 2014). Um fenômeno recorrente nos últimos anos é a substituição das áreas de pastagem por monocultura de soja. Em Alta Floresta, a implantação da sojicultora ocorreu a partir de 2006 e teve um aumento significativo nos últimos anos. Após dez anos decorridos de sua implantação ainda não se tem dados referentes aos impactos ambientais e sociais que esse empreendimento está causando ou causará ao ambiente e à população do município.

Neste contexto o desenvolvimento da pesquisa realizada em janeiro de 2017 no município de Alta Floresta-MT teve por objetivo levantar informações que visem expor os impactos ambientais e sociais que a sojicultora poderá causar, bem como identificar estratégias para conciliar o cultivo da sojicultora com a produção agroecológica no município.

\section{MATERIAL E MÉTODOS}

Para a obtenção dos dados foi elaborado um roteiro de entrevista, que foi aplicado a pessoas envolvidas direta ou indiretamente com trabalhos, pesquisas e estudos com manejo, agropecuária, agricultura e agroecologia no município.

As entrevistas foram realizadas com um professor representante da Universidade do Estado de Mato Grosso (UNEMAT), um Engenheiro Agrônomo que presta serviços de consultoria e assessoria rural no município, um Biólogo representante de uma Organização Não Governamental, o Instituto Centro de Vida (ICV), um Engenheiro Agrônomo que responde pelo Instituto de Defesa Agropecuária (INDEA) e um Biólogo e Técnico Agrícola, servidor da Empresa Mato-grossense de Pesquisa, Assistência e Extensão Rural (EMPAER).

A pesquisa teve como base duas perguntas piloto:

(i) Existem pesquisas sendo realizadas sobre o impacto ambiental e social em relação ao avanço da agricultura convencional (sojicultora), em nosso município?)

(ii) Quais as possíveis consequências ambientais, sociais e econômicas da conversão de áreas de pecuária (pastagem) para a agricultura baseada na soja para o município de Alta Floresta?

A partir dessa pergunta piloto outras perguntas foram elaboradas, a fim de obter resultados relevantes para a pesquisa.

\section{RESULTADOS E DISCUSSÃO}

Quanto ao questionamento sobre as possíveis consequências ambientais, sociais e econômicas da conversão de áreas de pecuária (pastagem) para a agricultura baseada na soja para o município de Alta Floresta, o Agrônomo (INDEA) entrevistado afirma que atualmente, no município de Alta Floresta, há 35 propriedades que aderiram a sojicultura (a maior tem 4.000 hectares). Este afirma ainda que a pecuária (gado), não chegará a seu fim, apenas terá um declínio. Quanto aos aspectos econômicos e sociais, ele afirma que haverá mais empregos, mais máquinas, cursos técnicos para área, mais fluxo de caixa no município e proprietários arrendando áreas para plantio de soja.

Houve um aumento de 50\% da soja de 2016 para 2017, em sua percepção. No entanto, um dos fatores que afetam a economia local é questão de que para a soja, os insumos não são adquiridos aqui e sim em outros municípios ou fora do estado. Economicamente, este fator tem um impacto negativo, uma vez que a pecuária, consome insumos locais. De fato, a necessidade de constantes investimentos para aumento de produtividade e sua alta dependência de insumos externos confere caráter excludente para este modelo, 0 
que se torna ainda um problema maior impondo restrições a agricultura de pequena escala, gerando, desta forma, um ciclo vicioso de concentração de terras e renda (OLIVAL et al. 2016).

Quanto a impactos ambientais, o entrevistado destaca a contaminação do solo e da água, pois os agrotóxicos atingem as propriedades próximas. Ele ressalta ainda o fato de já haverem denúncias de contaminação. Afirma que a contaminação pode estar relacionada à falta de experiências nas aplicações de veneno, porém reserva esta responsabilidade a órgãos como à Secretaria de Estado do Meio Ambiente (SEMA) e ao Instituto Brasileiro do Meio Ambiente e dos Recursos Naturais Renováveis (IBAMA). Ainda sobre o uso de agrotóxicos, o agrônomo informa que no município ocorrem casos em que alguns produtores aplicam, na soja, agrotóxicos destinados a outras cultivares.

Segundo o Biólogo e Técnico Agrícola (EMPAER), o agronegócio vai se instalar no Município, porém vai ser um processo lento e até necessário. Em sua percepção, No Norte do Mato Grosso, se as pastagens não forem recuperadas, vão se tornar inviáveis, tecnicamente e economicamente, pois as mesmas estão morrendo, devido à morte súbita do capim "Brachiaria brizantha". Entretanto, se não houver reforma das pastagens, como por exemplo, correção de solo (nutrientes), todas vão virar "juquira” (plantas invasoras) e quem continuar insistindo, terá prejuízo. A transição para agricultura ou a reforma do pasto, serão pontos positivos, pois essas áreas ficarão produtivas e também recuperadas. Este ainda alerta que a insistência na pecuária levará a "desertificação", principalmente em áreas em que a fertilidade natural é muito baixa.

Em relação à economia, este argumenta que a agricultura gera mais empregos no meio rural e urbano quando comparada à pecuária. A soja poderia, em sua concepção, oferecer emprego aos Agrônomos, numerosos na região devido ao curso de graduação na área ofertado pela Universidade do Estado do Mato Grosso (UNEMAT), vendedores e ainda gerar mão de obra no campo.

Para o Engenheiro Agrônomo, que presta serviço de consultoria e acessória rural no município, a soja tem sido um bom empreendimento pois ela tem sido implantada de modo rentável. Segundo ele, os produtores estão consolidando a soja com a agropecuária, o que possibilita a manutenção do solo e garante a qualidade dos pastos. Em relação à existência de impactos decorrentes desse empreendimento, ele afirma que existe sim impacto social e ambientais sendo esses, visíveis, porém ele defende que a população precisa se alimentar, enfatizando que a maioria da população consome produtos que tem origem direta da soja, e cita o óleo de soja como exemplo, além de existirem outros produtos com incorporação da soja durante o processo de produção, como a carne suína por exemplo. O Engenheiro defende o aumento da produção da soja ou de qualquer outra cultivar, pois segundo ele a população precisa se alimentar.

Quando questionado sobre o uso de agrotóxicos ele respondeu que não é possível ter controle sobre o uso desses agrotóxicos pelos agricultores, uma vez que não há o acompanhamento contínuo da fiscalização pode haver riscos à saúde humana e animal, e também prejudicar microrganismos presentes no solo. Do ponto de vista geral, o Engenheiro diz: "A soja é rentável e pode sim ser um bom empreendimento para o município, apesar de que a pecuária ainda é dominante e vai continuar, pois a soja é por ciclos, dá para trabalhar com a pecuária e a sojicultora tranquilamente".

Segundo o professor da UNEMAT não existem pesquisas sendo realizadas sobre o impacto ambiental e social em relação ao avanço da agricultura convencional (sojicultora), sendo que os únicos esforços voltados a questões de produção. Um exemplo são os trabalhos desenvolvidos, sobretudo pelos acadêmicos da universidade, que buscam desenvolver promotores de crescimento (bactérias) para reduzir o uso de nitrogênio no momento do plantio da soja.

O professor ressalta que a soja não está causando impactos ambientais, pois tem sido implantada junto com o sistema agropecuário, desta forma não é necessária a abertura de novas áreas para realizar o plantio. Inclusive, segundo ele, as áreas utilizadas para plantio são áreas de pastagem degradadas devido a fatores como a morte súbita do capim e por mau uso do solo. Com a implantação da soja essas áreas têm sido recuperadas, em sua percepção.

Em relação aos impactos que esse empreendimento pode causar a saúde humana, o professor acredita que é possível que impactos ambientais e sociais possam ocorrer. Segundo ele, o aumento do uso de defensivos poderá trazer problemas futuros. Neste sentido, sugere que sejam desenvolvidas pesquisas para quantificar o grau de impacto causado por esses defensivos, por exemplo, ao solo e à saúde humana.

De acordo com o Biólogo entrevistado do Instituto Centro Vida, a instituição desenvolve alguns trabalhos em propriedades que cultivam a soja. Essas propriedades que estão sendo acompanhadas fazem parte de um Projeto aprovado junto com o IHD Solidariedade, um programa desenvolvido na União Europeia que visa dar suporte aos produtores adequarem sua produção à legislação ambiental, sobre em áreas de 
desmatamento ilegal. 0 projeto visa entender como está sendo o processo de implantação da soja na região. 0 trabalho não engloba a abordagem do uso de agrotóxicos, pois são necessários laboratórios que realizem as análises para identificar se os agrotóxicos estão danificando o solo, animais, plantas e cursos de água. E não existem pesquisas sendo realizadas em nível de impactos ambientais e sociais no momento, pelo Instituto.

A grande preocupação do Biólogo é em relação aos locais que as plantações de soja estão alcançando. Segundo ele, a implantação da sojicultora abrange as áreas próximas as margens de rios e lagos onde deveriam estar às áreas de APPs (Áreas de Preservação Permanentes). Ele enfatiza que existem plantações de soja que se localizam bem próximas a Bacia Mariana, o centro de captação de água da Cidade, e também, próximos a cabeceira do córrego Severo que atravessa a cidade. Segundo ele, a água do córrego é utilizada por moradores das imediações, e seria um risco se a mesma estivesse contaminada.

Em sua percepção, a parte positiva da chegada da soja em um primeiro momento é a econômica, a negativa é que posteriormente haverá redução do número de funcionários nas fazendas, devido ao uso de novas tecnologias, levando ao aumento do desemprego nesse setor. Ele acredita que existe também o risco da diminuição da agricultura familiar, devido a fatores provocados pelo uso de defensivos e também pela perda de espaço.

Este reafirma que o município não possui pesquisas em andamento para quantificar o grau de impactos que a sojicultora pode acarretar no âmbito ambiental e social. A realização de estudos que possam levantar dados e gerar resultados sobre os impactos ambientais e sociais como os de saúde é de suma importância para o poder público, pois de acordo com os dados levantados medidas podem ser tomadas e ações de intervenção podem ser executadas.

\section{CONCLUSÃO}

A realidade é que a soja já chegou isso é fato, e a ausência de estudos de impactos socioambientais cria um cenário em que não se sabe ainda o real impacto que esse empreendimento pode trazer. Então o que se pode esperar é que ela seja usada de forma ordenada. Além disso, expansão da soja irá trazer muito gasto à saúde pública, pois o uso sem controle dos defensivos irá causar contaminação da água e consequentemente afetar a saúde humana, e o desmatamento de novas áreas para plantio mudará ainda mais drasticamente a estrutura da paisagem da região.

Os órgãos públicos devem se pronunciar em favor da promoção dos direitos cidadãos, para que o município prospere de maneira sustentável, desenvolvendo assim uma gestão pública e democrática. Pequenos, médios e grandes produtores devem receber orientações para que a implantação das lavouras de soja ocorra de maneira sustentável atendendo aos requisitos básicos de implantação.

\section{REFERÊNCIAS}

[1] Barbosa, M. Z.; Assumpção, R. Ocupação territorial da produção e da agroindústria da soja no Brasil, nas décadas de 80 e 90. Informações Econômicas, São Paulo, v.31, n;11, p.7-16, 2001.

[2] Brandão, A.; Rezende, G.; Marquest, R. Crescimento Agrícola no Brasil no Período 1999-2004: Explosão da Soja e da Pecuária Bovina e seu Impacto sobre o Meio Ambiente, IPEA. Rio de Janeiro, 2005.

[3] Brasil. Governo do Brasil- Safra de gãos 2016/2017 deve chegar a 227,9 milhões de toneladas. Disponível em: www.brasil.gov.br/economia-e-emprego/2017/04/. Acesso em: 16/01/2018.

[4] Olival, A. A. et al. Resiliência da agricultura familiar na Amazônia: co-construção de um programa de pesquisa-ação multi-institucional no Brasil. VIII Congresso da Apdea, Esadr 2016.

[5] WWF. The growth of Soy: Impacts and Solutions. (O crescimento da soja: impactos e soluções). WWF International (secretariado internacional da Rede WWF), em Gland, na Suíça. ISBN: 978-2-940443-79-6, 2014. 


\section{Bapítulo 5}

INTEGRAÇÃO AGROECOLÓGICA PELA SOBERANIA ALIMENTAR EM COMUNIDADE QUILOMBOLA NA AMAZÔNIA AMAPAENSE, BRASIL

\section{Julia Franco Stuchi \\ Edilson Braga Rodrigues \\ Jorge Federico Orellana Segovia}

Resumo: A Agroecologia, orientando a agricultura à sustentabilidade no seu sentido multidimensional, apresenta nessa experiência uma proposta de oferecer aos agricultores familiares no extremo norte da Amazônia oriental brasileira uma alternativa ecológica para a soberania alimentar. Com a sinergia da atuação conjunta dos diversos atores por meio de visitas técnicas, oficinas, dias de campo e intercâmbio de experiências, buscou-se a coevolução do ambiente natural focado na qualidade de vida. Os resultados apresentaram alternativas de técnicas agroecológicas melhoradas e socializadas pelos atores rurais, capazes de trazer opções diversificadas de alimentos saudáveis para a comunidade, assim como possibilidades de ampliar seu mercado e oportunidades de aumento de renda. Concluiu-se assim que a participação dos protagonistas em todas as fases do processo trouxe uma resposta positiva às suas próprias aspirações, principalmente buscando alternativas de enfrentar as dificuldades coletivamente.

Palavras-chave: Produção sustentável; Orgânicos; Agricultura familiar; Construção do conhecimento. 


\section{CONTEXTO}

Conforme Lamarche (1993), as estratégias de produção e reprodução da exploração familiar são organizadas e pensadas mediante seu passado histórico, com suas raízes culturais e o modo de vida mais tradicional, assim como para atingir o melhor desempenho que os projetam para o seu futuro. Nesse sentido, Finatto e Salomoni (2008), indicam que os agroecossistemas familiares também representam traços compatíveis com os princípios do desenvolvimento sustentável, que permitem o redesenho dos agroecossistemas, adaptando-os aos princípios de uma nova proposta de desenvolvimento, que priorize os pilares da sustentabilidade.

No Estado do Amapá observa-se que a insuficiência de renda, associada às deficiências como baixa escolaridade, ausência de saneamento básico e de atendimento à saúde, deficientes condições de habitação e moradia, entre outras, refletem diretamente no contexto socioeconômico (SEGOVIA, 2011). Desta forma, esses fatores expõem um contingente amplo da população de agricultores rurais de base familiar a total vulnerabilidade nos processos produtivos, colocando em risco de desabastecimento agroalimentar, proveniente da produção agrícola local (GONÇALVES, 2010).

Nessa realidade, as 70 famílias da comunidade quilombola São João I do Maruanum II trazem historicamente as atividades de caça, pesca e a agropecuária, e como principais produtos a criação bubalina nos campos alagados da comunidade, a mandioca (Manihot esculenta) usada para a produção de farinha, e a macaxeira (Manihot utilissima) para o consumo direto. No entanto, procurando formas para a soberania alimentar e incremento de renda, a comunidade procurou a Assistência Técnica e a Extensão Rural (ATER) local para iniciar a produção de hortaliças e frutas de base ecológica, que por sua vez foi buscar na Embrapa Amapá mais subsídios técnicos para tal.

Assim, o presente trabalho indaga se a agricultura familiar na referida comunidade quilombola do extremo norte da Amazônia oriental brasileira representa um modelo que permita sua reprodução com capacidade de promoção do enfrentamento da insegurança no abastecimento agroalimentar.

\section{DESCRIÇÃO DA EXPERIÊNCIA}

A experiência foi desenvolvida na comunidade quilombola São João I do Maruanum II, localizada no Distrito de Maruanum, a 40 km do centro do município de Macapá, Estado do Amapá, Brasil. A experiência foi iniciada a partir de uma demanda estruturada desta comunidade quilombola à extensão rural local, logo vinculada a um projeto de base agroecológica que estava sendo desenvolvido na Empresa Brasileira de Pesquisa Agropecuária (Embrapa Amapá) para a produção orgânica de hortaliças e frutas tropicais. Foram assim realizadas 160 horas de trabalho onde foram introduzidas em bases agroecológicas 14 espécies de hortaliças com potencial de desenvolvimento favorável para as condições edafoclimáticas locais. A experiência contou com as 70 famílias da comunidade.

0 trabalho desenvolvido contou com: 1) Visitas técnicas; 2) Oficina de construção do cultivo protegido; 3) Oficina de compostagem orgânica; 4) Oficina de horticultura orgânica; 5) Oficina sobre fertilidade do solo e de hortaliças; 6) Oficina sobre fertilização do solo e adequação da adubação para horticultura; 7) Oficina sobre cultivo agroecológico de hortaliças (Figura 1); 8) Dias de campo sobre horticultura orgânica e cultivo de culturas diversificadas; 9) Intercâmbio de experiências com atores locais e estrangeiros (Figura 2). 
Figuras 1 e 2. Oficina de cultivo ecológico de hortaliças na comunidade quilombola de São João/ Distrito de Maruanum, Macapá-AP; Intercâmbio internacional de experiências.

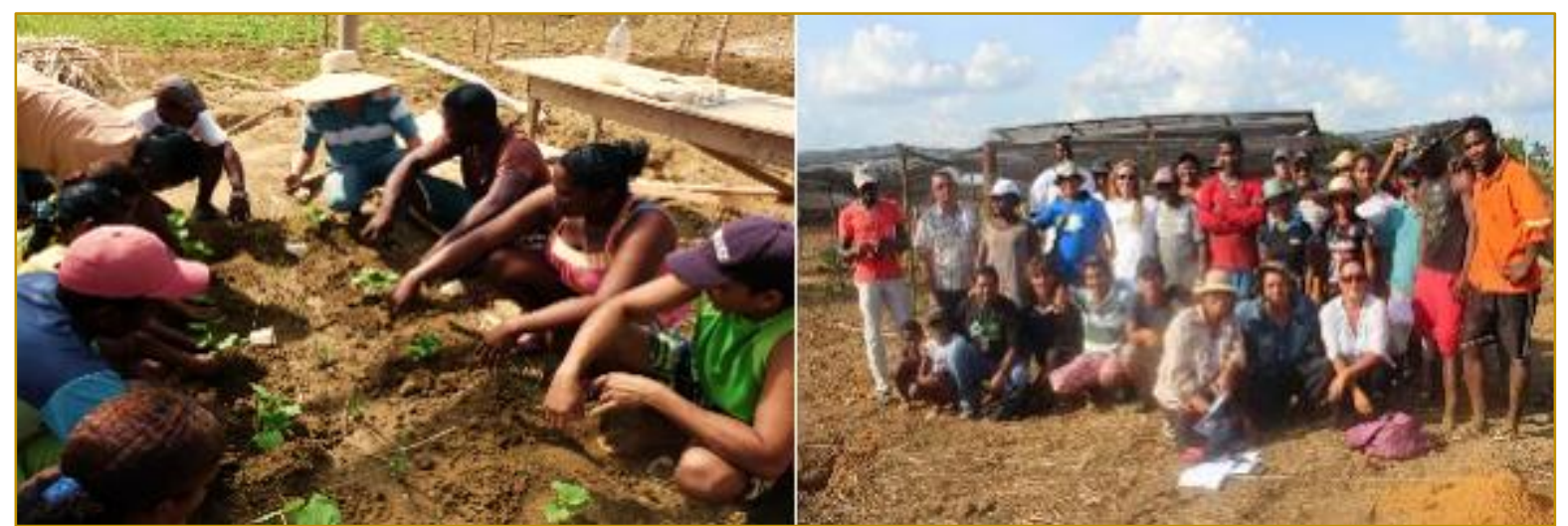

Fonte: Julia Stuchi, 2014.

A temática foi pesquisada com a utilização do método qualitativo e quantitativo. No método de amostragem para as entrevistas foi determinado $10 \%$ do universo total de agricultores familiares, representados por sete quilombolas ao acaso, dois extensionistas e um pesquisador da Embrapa Amapá. A atividade embasou-se em três pilares: inovação em agrotecnologias ecológicas; sinergia do trabalho participativo; e possibilidade de empoderamento da comunidade visando a soberania alimentar.

Para avaliar o processo de construção participativa das práticas agroecológicas adotadas foram realizadas entrevistas com 15 perguntas contendo valores de zero (extremamente mal) a 10 (excelente). Além da quantificação, foram registrados os depoimentos qualitativos de cada uma das avaliações dentro dos seguintes pontos: 1) Integração entre a pesquisa, extensão rural e a comunidade; 2) Construção teórica do conhecimento; 3) Construção prática do conhecimento; 4) Qualidade do conteúdo transferido; 5) Qualidade do material didático (apostilas, filmes, projeções); 6) Adequação e suficiência de material prático (sementes, adubos e material de apoio); 7) Aproveitamento de recursos disponíveis no local; 8) Frequência dos profissionais de extensão e pesquisa na comunidade; 9) Qualidade do material genético (sementes de cada espécie); 10) Participação da comunidade no processo, incluindo o desempenho da liderança; 11) Disponibilidade de insumos agrícolas externos; 12) Disponibilidade de máquinas e equipamentos, incluindo adequação e suficiência de equipamento de irrigação; 13) Possibilidade de não usar agrotóxicos; 14) Quantidade de espécies trabalhadas na unidade demonstrativa, totalizando 14 espécies; 15) Possibilidade da preparação dos insumos orgânicos na propriedade.

\section{RESULTADOS}

De acordo com a avaliação das atividades desenvolvidas, é de extrema significância a demanda da comunidade pelo cultivo de hortaliças sem aplicação de agrotóxicos, assim como o reaproveitando de resíduos sólidos e líquidos gerados pela própria comunidade (Figura 3). Percebe-se que através de uma gama de conhecimentos em agroecologia foi possível compartilhar, desenvolver e apropriar tecnologias capazes de gerar bens e serviços voltados para agricultura familiar. Dentre as práticas implementadas destacaram-se a reciclagem de resíduos sólidos (esterco bubalino, restos vegetais das lavouras, cinzas) utilizados na compostagem e adubação e o uso de tucupi (sumo extraído da raiz da mandioca brava) no controle de pragas. 
Figura 3. Resultados da avaliação do processo de construção participativa das práticas agroecológicas adotadas pela comunidade São João I do Maruanum II.

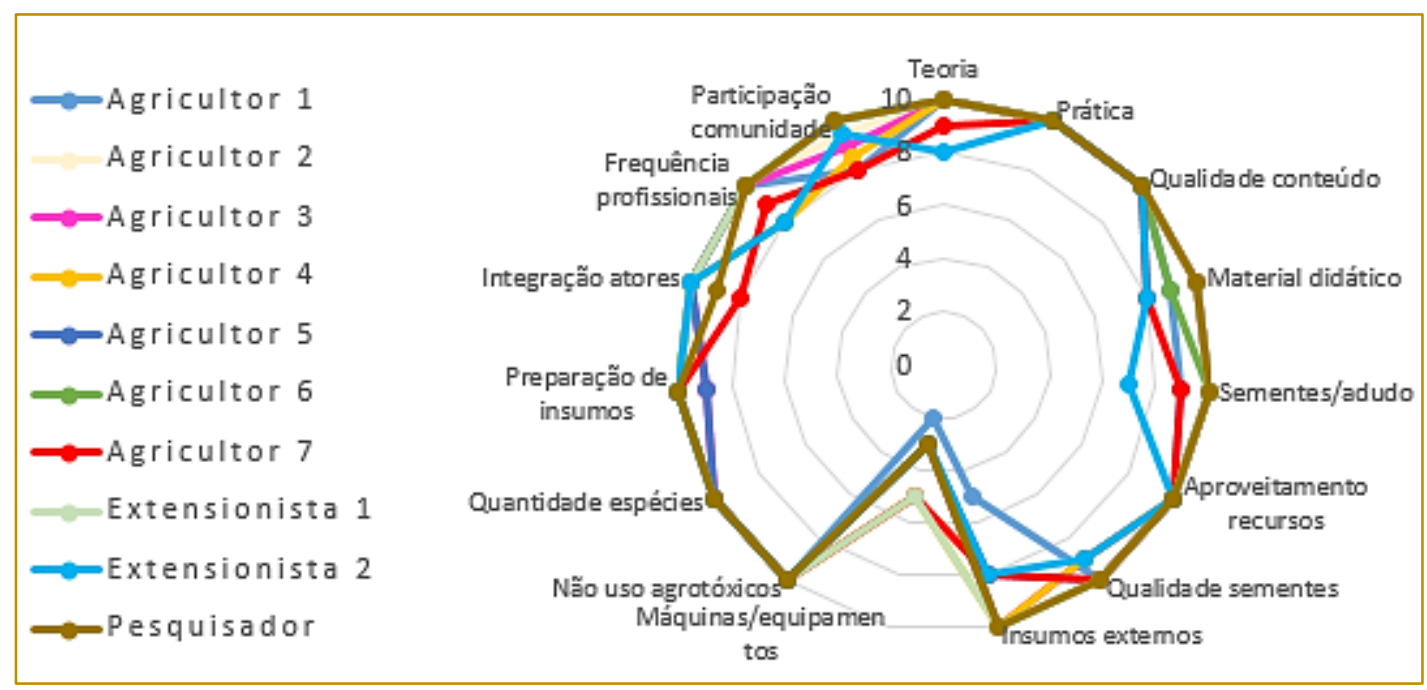

As inspeções fitossanitárias mostraram que a utilização do tucupi foi eficiente no controle de pragas devido a presença de cianetos, que respondem pelas ações inseticida, acaricida e nematicida, e a alta concentração de enxofre, que atua como fungicida, inseticida e acaricida (Pontes, 2006). A baixa incidência de doenças foi também o resultado de alguns cuidados essenciais, como a utilização de solo para substrato colhido na profundidade de $50 \mathrm{~cm}$ abaixo da superfície, o tratamento térmico de sementes (50oC/25 minutos), o tratamento químico das sementes com extrato de própolis (10 gotas de própolis $/ 100 \mathrm{~mL}$ de água), as pulverizações quinzenais com extrato de própolis $(10 \mathrm{~mL}$ de própolis/20L de água), as pulverizações semanais com tucupi, e a manutenção das mudas em viveiro telado até o transplante.

No que diz respeito a qualidade do conteúdo e material didático desta experiência, recomenda-se a adaptação de apostilas e filmes às condições de entendimento do público envolvido, com uma linguagem simples, assim como cartilhas e folders didáticos adequados à baixa escolaridade dos comunitários em questão.

O maior entrave para o desenvolvimento da experiência foi a dificuldade de acesso a máquinas e equipamentos de preparo de solo (microtrator e rotocanteirador) e equipamento de irrigação (bombas, conexões, aspersores e gotejadores), considerados fundamentais ao desenvolvimento da horticultura entre os agricultores familiares.

Denota-se que neste processo, a capacidade de criar, gerir e difundir conhecimento de forma participativa mostrou grande eficiência e tornou-se um fator decisivo na qualidade do conhecimento produzido e multiplicado, mostrando que é possível ter maior rentabilidade, soberania alimentar e nutricional em menor prazo de tempo com a produção de hortifruti.

\section{CONSIDERAÇÕES FINAIS}

O processo de capacitação teórico e prático juntamente com o intercambio de experiências agroecológicas possibilitaram encontrar alternativas de baixo custo para a adubação e para o controle de pragas das culturas, garantindo a produção de alimentos isentos de resíduos de agrotóxicos e reduzindo a necessidade de aquisição de insumos externos do solo.

A construção do conhecimento coletivo trazida na experiência dos distintos grupos de atores possibilitou a utilização de tecnologias agroecológicas adaptadas às condições ambientais e socioeconômicas da região, gerando diversificação e aumento na produtividade das culturas alimentares. Essa conquista só foi possível através da sinergia do trabalho participativo entre agricultores, extensionistas e pesquisadores, permitindo o empoderamento dos conhecimentos de produção pela comunidade visando a soberania alimentar. Desta forma, oportunizou-se a possibilidade de aumentar a segurança agroalimentar da comunidade quilombola garantindo sua reprodução no enfrentamento da fome e no auxílio complementar à renda. 


\section{AGRADECIMENTOS}

Um especial agradecimento a força de vontade da comunidade quilombola protagonista deste trabalho; à Emater local (Rurap) especificamente nas pessoas de Morubiaxaba e Galviston, que não mediram esforços para concretizar o sonho destes campesinos; à estagiária Aolibama, sempre disposta e solícita; ao técnico agrícola Edilson Rodrigues, pela maestria que realiza seu trabalho.

\section{REFERÊNCIA}

[1] Finatto, R. A.; Salamoni, G. Agricultura familiar e agroecologia: perfil da produção de base agroecológica do município de Pelotas/RS. Uberlândia: Sociedade \& Natureza, 20 (2): 199-217, 2008.

[2] Gonçalves, M. C. A. Desempenho da agricultura familiar na segurança do abastecimento agroalimentar do estado do Amapá. 2010. 140 f. Dissertação (Mestrado em Desenvolvimento Regional - Mestrado Integrado em Desenvolvimento Regional-MINTEG). Universidade Federal do Amapá. Macapá, 2010.

[3] Lamarche, H. Agricultura familiar: Comparação Internacional. Campinas/SP: Ed: UNICAMP, 1993. 336p.

[4] Pontes, J. J. da. Cartilha da manipuera: uso do composto como insumo agrícola. Fortaleza: Banco do Nordeste do Brasil. 2006.

[5] Segovia, J. F. O. Dimensão da agricultura familiar e periurbana no estado do Amapá: desafios para o abastecimento frente à urbanização. Tese (Doutorado do Programa de Pós-Graduação em Desenvolvimento Sustentável do Trópico Úmido - NAEA). Universidade Federal do Pará, Belém, 2011. 


\section{Paṕlitulo 6}

PROJETO NASCENTE VIVA: AÇÕES SOCIOECONÔMICAS E AMBIENTAIS NA RESERVA INDİGENA DE DOURADOS-MS

\section{Larissa Oliveira Vilela}

Jessica Ferreira da Silva

Ana Caroliny de Queiroz Fernandes

Cleide Brachtvogel

Zefa Valdivina Pereira

Júlio César Pereira Lobtchenko

Resumo: A reserva indígena de Dourados, compreendida pelas Aldeias Bororó e Jaguapirú, foi criada em 1917 com uma área de 3.474 ha. Neste espaço vivem confinadas, hoje, mais de 15.000 pessoas. Esse grande contingente populacional levou ao esgotamento dos recursos naturais essenciais para a sua sobrevivência. Criou ainda sérios impasses para a convivência da população aglomerada na reserva, o que se expressa no agravamento de problemas sociais como a violência, droga, álcool, miséria, conflitos internos, desnutrição infantil e mesmo em frequentes surtos epidêmicos de suicídios. Frente a esse quadro de degradação, fica evidente a necessidade de restauração, não só para se adequar a legislação, mas também reconstruir um ecossistema autossustentável, bem como proporcionar à comunidade indígena um lugar para usufruir de maneira respeitosa dos recursos naturais como os rios, os animais, as plantas e admirar as belezas, resgatando assim uma parte de sua cultura. Assim, é de fundamental importância o desenvolvimento de estratégias que visem à proteção, recuperação e a sustentabilidade da reserva indígena de Dourados, através de alternativas de uso dos recursos naturais, bem como alternativas de geração de renda para essas populações. Dessa forma este projeto tem por objetivo promover a restauração ecológica e a conservação da biodiversidade por meio do uso sustentável dos recursos naturais da Aldeia de Dourados como alternativa de desenvolvimento local e a melhoria na quantidade e qualidade da água para usos múltiplos.

Palavras-chave: Sustentabilidade, Guarani-Kaiowá, Área de Preservação Permanente 


\section{CONTEXTO}

O estado do Mato Grosso do Sul destaca-se no território nacional em termos de biodiversidade uma vez que abriga três dos grandes biomas Floresta Atlântica, Cerrado e Pantanal, além da influência do Chaco e da Floresta Amazônica, o que resulta em uma paisagem florística bastante diversificada.

Associado a essa rica biodiversidade, o estado tem a maior população indígena do país, mais de 60.000 indígenas, quase $10 \%$ da população total no Brasil. Esses contingentes agrupam-se em sete povos distintos: Kadiwéu, Ofaiet, Terena, Guarani e Kaiowá, Kamba e Atikum. Dentre eles, os Guarani e Kaiowá e os Terena representam dois dos mais numerosos povos indígenas do país.

Contudo, o processo de ocupação do estado, assim como em outras regiões, caracterizou-se pela falta de planejamento e consequente destruição dos recursos naturais, particularmente das florestas. A cobertura florestal nativa foi sendo fragmentada, cedendo espaço para as culturas agrícolas e as pastagens, bem como o avanço da fronteira urbana que se estendeu por áreas impróprias como fundos de vales e áreas de nascentes acelerando e intensificando desta forma, a degradação do ambiente natural (MATO GROSSO DO SUL, 2000).

Semelhantemente ao que aconteceu com a biodiversidade do Mato Grosso do Sul, as populações indígenas Guarani-kaiowá foram fragmentadas e confinadas a espaços extremamente exíguos. Esse processo de expropriação territorial e confinamento impuseram profundas limitações a sua economia, bem como o esgotamento dos recursos naturais, a desvalorização cultural e a perda de sua identidade (BRAND, 2007). Também se traduziu, inevitavelmente, no desaparecimento de inúmeros povos indígenas. A apropriação, por parte dos colonizadores, dos territórios indígenas, assim como a consequente exploração de suas riquezas naturais, caracterizou-se como um processo de forte homogeneização cultural e de crescente comprometimento da diversidade ambiental (BRAND, 2007).

Como consequência desse longo processo histórico de expropriação territorial e desestruturação sociocultural parte da subsistência das famílias é garantida com o trabalho assalariado dos homens nas usinas de produção de açúcar e álcool, enquanto crescem os índices de desnutrição infantil e de suicídio entre os jovens. Os Kaiowá e Guarani manifestam, atualmente, uma forte dependência de ações emergenciais, sobretudo com relação à provisão de alimentos e de assistência médica, seja de forma oficial, seja por ações voluntárias a partir de mobilização de setores da sociedade civil (BRAND, 2007).

Não ocorreu diferente no município de Dourados, onde em 1917 pelo Decreto Estadual 401, foi criada a Reserva Indígena de Dourados, compreendida pelas Aldeias Bororó e Jaguapirú. 0 título definitivo da área, legalizada como patrimônio da União, foi emitido em 1965 (MONTEIRO, 2003), com uma área de 3.474 ha. Neste espaço vivem hoje mais de 15.000 pessoas (FUNAI, 2018), cerca de 18\% da população indígena do estado.

Esse grande contingente populacional levou ao esgotamento dos recursos naturais essenciais para a sua sobrevivência a partir da perspectiva histórica cultural indígena de forma que inviabilizam a realização da sua reprodução social, mística e cultural, a partir de uma perspectiva histórica, uma vez que sua relação com o território se encontra fragilizada (SANTANA JUNIOR, 2010). Surgiram ainda sérios impasses para a convivência da população aglomerada na reserva, o que se expressa no agravamento de problemas sociais como a violência, drogas, alcoolismo, miséria, conflitos internos, desnutrição infantil e mesmo em frequentes surtos epidêmicos de suicídios. Além dos problemas sociais enfrentados pela aldeia de Dourados, estes carecem ainda de água potável, de rede de tratamento de esgoto, bem como a coleta de lixo, ou seja, esta comunidade se encontra excluída das políticas municipais de água e saneamento.

Cabe ressaltar ainda que com o desmatamento houve a extinção de várias espécies que antes eram usadas pela comunidade, o que provocou a erosão do solo e assoreamento dos cursos de água. Frente a esse quadro de degradação, fica evidente a necessidade de restauração não só para se adequar à legislação, mas também reconstruir um ecossistema autossustentável, bem como proporcionar a comunidade indígena um lugar para usufruir de maneira respeitosa os recursos naturais como os rios, os animais, as plantas e admirar as belezas, resgatando assim uma parte de sua cultura. Desse modo, é de fundamental importância o desenvolvimento de estratégias que visem à proteção, recuperação e sustentabilidade da Aldeia de Dourados, através de alternativas de uso dos recursos naturais, além de alternativas de geração de renda para as populações.

Dessa forma este projeto tem por objetivo promover a restauração ecológica e a conservação da Biodiversidade por meio do uso sustentável dos recursos naturais da Aldeia de Dourados como alternativa de desenvolvimento local e a melhoria na quantidade e qualidade da água para usos múltiplos. 


\section{DESCRIÇ̃̃O DA EXPERIÊNCIA}

A Reserva Indígena de Dourados tem seus limites territoriais juntos aos limites do perímetro urbano do município de Dourados, MS, ficando a norte da cidade. A sua composição étnica é composta por três etnias: Caiuás (Kaiowá), Guarani (Ñandeva) e os Terena. Divididas em duas aldeias: a Bororó e a Jaguapirú.

Os fragmentos florestais, constituídos por remanescentes da formação Florestal Estacional Semidecidual, representam 4\% da área total da reserva (SOARES \& PEREIRA, 2015) e se encontram em péssimo estado de conservação devido às pressões da superpopulação.

Conforme Soares \& Pereira (2015) a Aldeia de Dourados apresenta três tipologias de ocupação do solo. As áreas de uso econômico representa $83 \%$ do total da reserva e estes locais são consolidados pelo processo de ocupação, no qual se verifica o predomínio de moradias associadas a atividades econômicas de subsistência (agricultura, pastagem e pomares) e infraestrutura diversas (SOARES \& PEREIRA, 2015).

As áreas úmidas compreendem $13 \%$ são áreas de várzea associadas às nascentes e que acompanham os fundos de vale ao longo dos cursos d'água. Apesar das restrições impostas pelas suas características naturais, sobretudo pela saturação hídrica comum aos locais de ocorrência de gleissolos, que as configuram como locais de instabilidade geofísica, essas áreas vêm sendo pressionadas pela ocupação por moradias e atividades agropastoris as quais refletem na gradativa supressão dos campos hidrófilos e das matas ciliares, comprometendo os serviços ambientais desempenhados pelo sistema (SOARES \& PEREIRA, 2015). A falta de cobertura vegetal nas margens desses córregos e nascentes tem causado assoreamento e um grande acúmulo de sedimentos nos leitos, o que fez com que em muitas partes já não exista mais o leito dos córregos, apenas uma área úmida, que quando chove invade as casas próximas aos córregos.

A ausência de vegetação arbórea e a predominância de gramíneas encontradas nas margens das nascentes e córregos caracterizam-se como um fator de degradação, já que aumentam a probabilidade de erosões e potencializam o desmoronamento das margens, entre outros fatores agravantes. Além disso, está em desacordo com a legislação do Código Florestal Brasileiro que prevê uma faixa de florestas e demais formas de vegetação natural de 30 metros para os cursos d'água de menos de 10 metros de largura e 50 metros para nascentes e áreas úmidas com solos hidromórficos. Na figura 1 é possível evidenciar o estado de alguns córregos dentro da Aldeia.

Figura 1. Vista geral dos córregos da Aldeia de Dourados, MS.

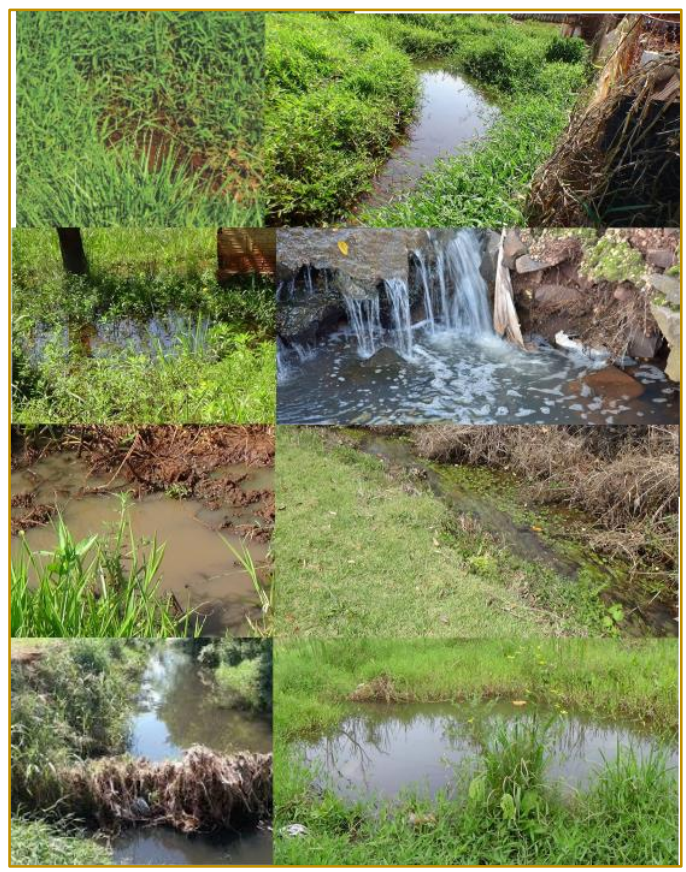

O início do projeto contou com um diagnóstico para evidenciar os passivos ambientais das Aldeias, posteriormente foi elaborado o PRARA para as aprovações legais. A primeira ação do projeto foi a remoção da vegetação herbácea e invasora e a retirada de areia da calha do córrego com maquina retroescavadeira. Posteriormente fez-se o plantio de mudas ou outra técnica evidenciada pelo diagnóstico. 
Também foi realizado atividades de educação ambiental, oficinas sobre coleta, beneficiamento de sementes, produção de mudas e tipos de adubação.

Foi instalado um viveiro na Escola Estadual da Aldeia de Dourados, este espaço além da produção de mudas destinará a formação. Os Viveiros Educadores são espaços de produção de mudas de espécies vegetais onde, além de produzi-las, desenvolve-se de forma intencional processos que buscam ampliar as possibilidades de construção de conhecimento, exercitando em seus procedimentos, práticas e reflexões que tragam em seu bojo, o olhar crítico sobre questões relevantes para a Educação Ambiental como: ética, solidariedade, responsabilidade socioambiental, segurança alimentar, inclusão social, recuperação de áreas degradadas entre outras possibilidades. Assim, tais viveiros são espaços onde a produção de mudas é tratada como porta de entrada para reflexões mais profundas sobre as causas e possibilidades de enfrentamento para a problemática socioambiental.

\section{RESULTADOS}

Este trabalho proporcionou a interação entre a academia e os conhecimentos tradicionais das comunidades indígenas, visando não só à Preservação/Recuperação dos Recursos Naturais de suas respectivas reservas como também projetos alternativos para um desenvolvimento local de sustentabilidade duradoura, os quais minimizem os impactos ambientais produzidos.

Na figura 2 e 3 é possível observar algumas atividades realizadas durante a vigência do projeto.

Figura 2. Vista geral das atividades do projeto, limpeza do leito, plantio e palestra, na aldeia de Dourados, MS.

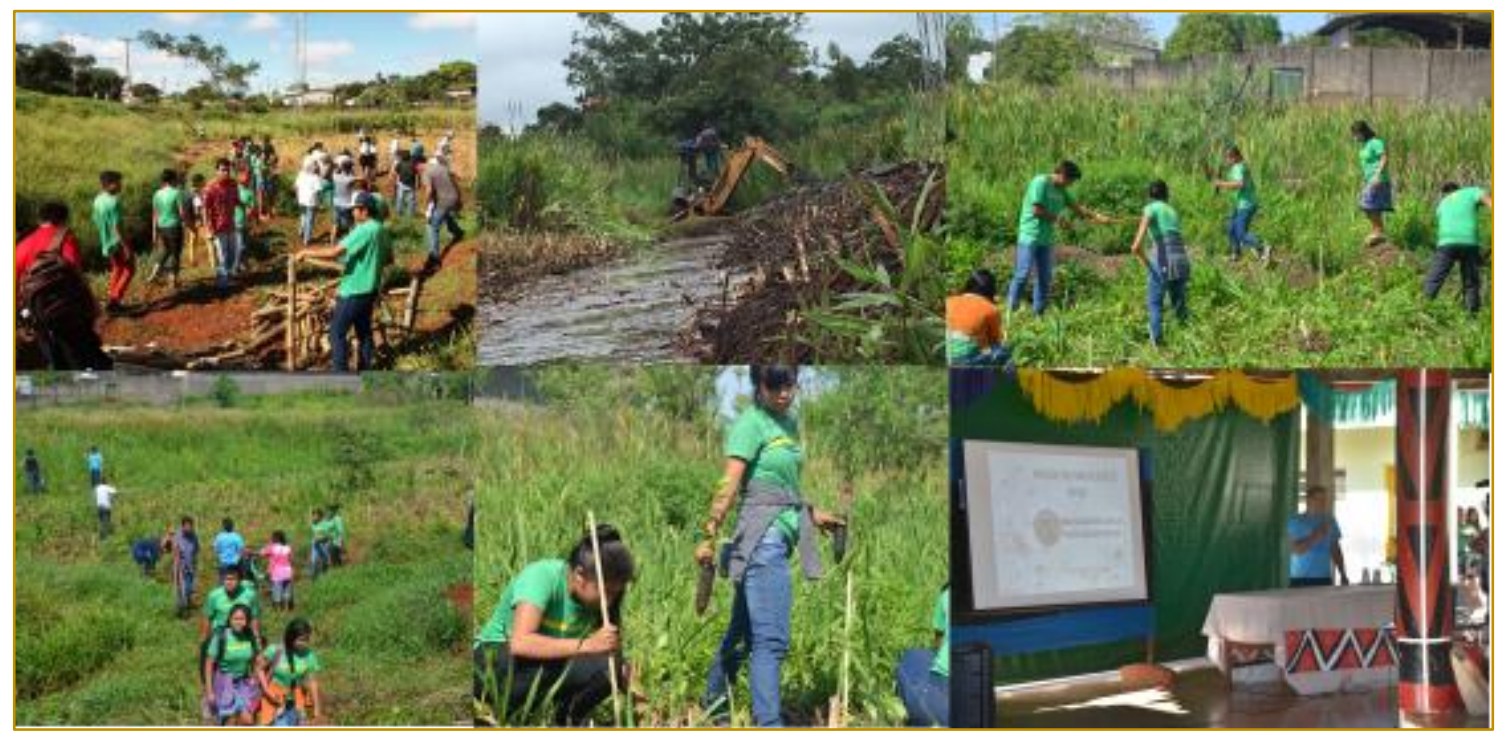


Figura 3. Construção do viveiro e curso de produção de mudas na Escola Guateka e estado atual do córrego Jaguapirú, na aldeia de Dourados, MS.

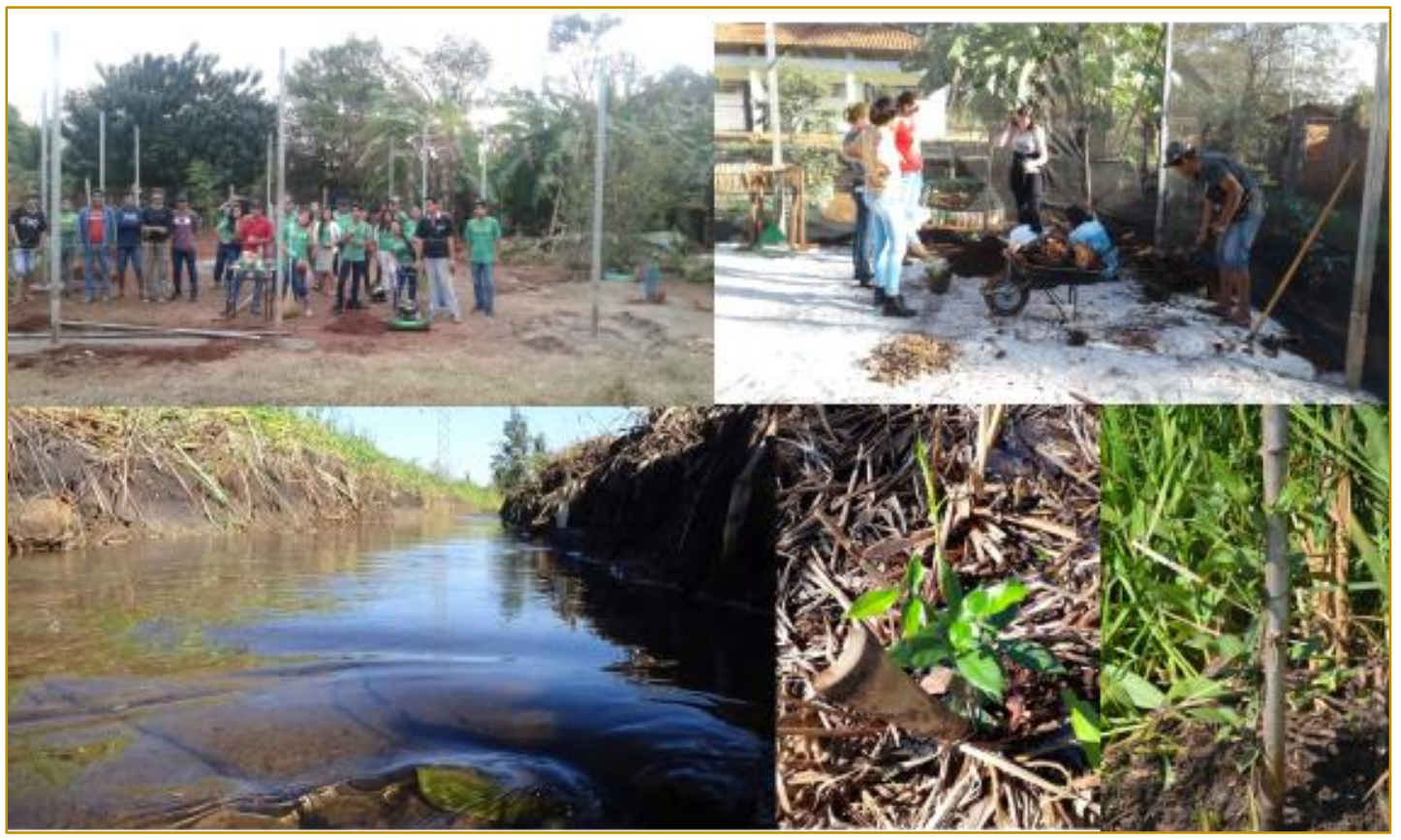

O projeto conta com cinco agentes ambientais, que são alunos indígenas do ensino médio os quais dedicam uma manhã por semana para desenvolver atividades no viveiro de mudas.

Espera-se com isso promover a conservação dos recursos hídricos da Aldeia de Dourados, contribuir para o restabelecimento de aspectos funcionais e estruturais de nascentes e olhos d'água; promover a formação e discussão sobre responsabilidade socioambiental, segurança alimentar, inclusão social, recuperação de áreas degradadas; desenvolver arranjos produtivos locais baseados na sustentabilidade; capacitar os integrantes do projeto para o desenvolvimento de uma cadeia produtiva de sementes florestais.

\section{AGRADECIMENTOS}

Ao Núcleo de Práticas Extensionistas (NPE) da Universidade Federal da Grande Dourados (UFGD) pelo apoio.

\section{REFERENCIAS}

[1] Brand, A. Povos indígenas na região do Pantanal e do Cerrado: desenvolvimento participativo, universidades e pesquisa-ação. Universidade Católica Dom Bosco, Campo Grande. 2007. 15p.

[2] Mato Grosso do Sul. 2000. Secretaria de Meio Ambiente. Fundação Estadual de Meio Ambiente Pantanal. Coordenadoria de Recursos Hídricos e Qualidade Ambiental. Divisão Centro de Controle Ambiental. Microbacia hidrográfica do Rio Dourados: diagnóstico e implantação da rede básica de monitoramento da qualidade das águas. Campo Grande, $78 \mathrm{p}$.

[3] Monteiro, M. E. B. Levantamento histórico sobre os índios Guarani Kaiwoá. Rio de Janeiro: Museu do Índio, 2003.

[4] Santana Junior, J.R. Produção e reprodução indígena: o vir e o porvir na reserva de Dourados/MS. CampoTerritório: revista de geografia agrária, v. 5, n. 9, p. 203-236, 2010.

[5] Soares, J.A.B, \& Pereira, J. G Diagnóstico ambiental da reserva indígena de Dourados-MS, Anais. VI Congresso Brasileiro de Gestão Ambiental Porto Alegre/RS - 23 a 26/11/2015. 


\section{Bapítulo 7}

\section{A PRODUÇÃO CAMPONESA NO ASSENTAMENTO DE REFORMA AGRÁRIA SÃO JUDAS}

\section{Francieli Aparecida Zenatti}

Rodrigo Simão Camacho

Resumo: 0 objetivo do artigo é explicar como ocorre a produção camponesa no assentamento de reforma Agrária São Judas. 0 Assentamento São Judas, que está localizado em Rio Brilhante MS, foi dividido em grupos e possui 187 lotes, onde as famílias residem e produzem, tanto para o consumo como para venda. Os assentados têm produções diversificadas, mas a maioria tem como principal fonte de renda a produção de leite, seguida por lavoura e gado de corte, além desta principal fonte de renda, eles tem plantios diversificados para o consumo da família e acabam vendendo o excedente. Algo bem marcante nos assentados é a forte ligação com a terra, e o desejo de produzir alimentos saudáveis para a alimentação familiar, outro ponto forte é que o trabalho é realizado em torno da mão de obra familiar. Como metodologia foi utilizado entrevistas por meio de um questionário semiestruturado com 10 famílias do assentamento e também fotografias da produção dos assentados.

Palavras-chave: Campesinato, Assentados, Trabalho Familiar, Autoconsumo, Produção Diversificada, Modo de Vida. 


\section{INTRODUÇÃO}

Com esse artigo buscamos compreender o que os camponeses produzem e como vivem em seus lotes por meio do trabalho familiar no assentamento são judas.

Precisamos entender a importância da reforma agrária e da agricultura para nossa sociedade, pois temos uma concentração de terras nas mãos de poucos e uma predominância da produção de monocultura com uso de agrotóxicos, o que prejudica a saúde e o meio ambiente, por isso desenvolvemos esse artigo para valorizar o modo de vida do camponês assentado pela reforma agrária, entendendo as suas formas de resistência para permanência no campo.

Em rio brilhante - ms, através da reforma agrária, foram criados vários assentamentos, dentre eles, o assentamento são judas, com 187 famílias contempladas, mas algumas dessas famílias não conseguiram permanecer no lote por falta de políticas de permanência. As fazendas desapropriadas para criação de assentamentos geralmente são de terras enfraquecidas pela monocultura, e no caso do assentamento são judas, não foi diferente. A pesar das dificuldades, atualmente no assentamento, tanto para as famílias que permanecem desde o início ou as que chegaram depois, constatamos na pesquisa a presença de uma produção diversificada com parte dela para autoconsumo e parte para venda.

\section{METODOLOGIA}

A metodologia de nossa pesquisa se baseou nas seguintes etapas: leitura de artigos sobre a reforma agrária e agricultura camponesa em livros, revistas, sites etc.; observação - participante, tendo em vista que a autora mora em um lote no assentamento São Judas; diálogo informal com os produtores do assentamento São Judas; levantamento de dados por meio de um questionário semiestruturado, onde entrevistamos 10 famílias; e fotografia da produção camponesa dos entrevistados.

\section{RESULTADOS E DISCUSSÕES}

O Assentamento São Judas, localizado em Rio Brilhante a sudoeste do Estado de Mato Grosso do Sul, região Centro-Oeste do Brasil. Veja o mapa de Rio Brilhante na figura 1.

Figura 1 - Mapa de localização do município de Rio Brilhante

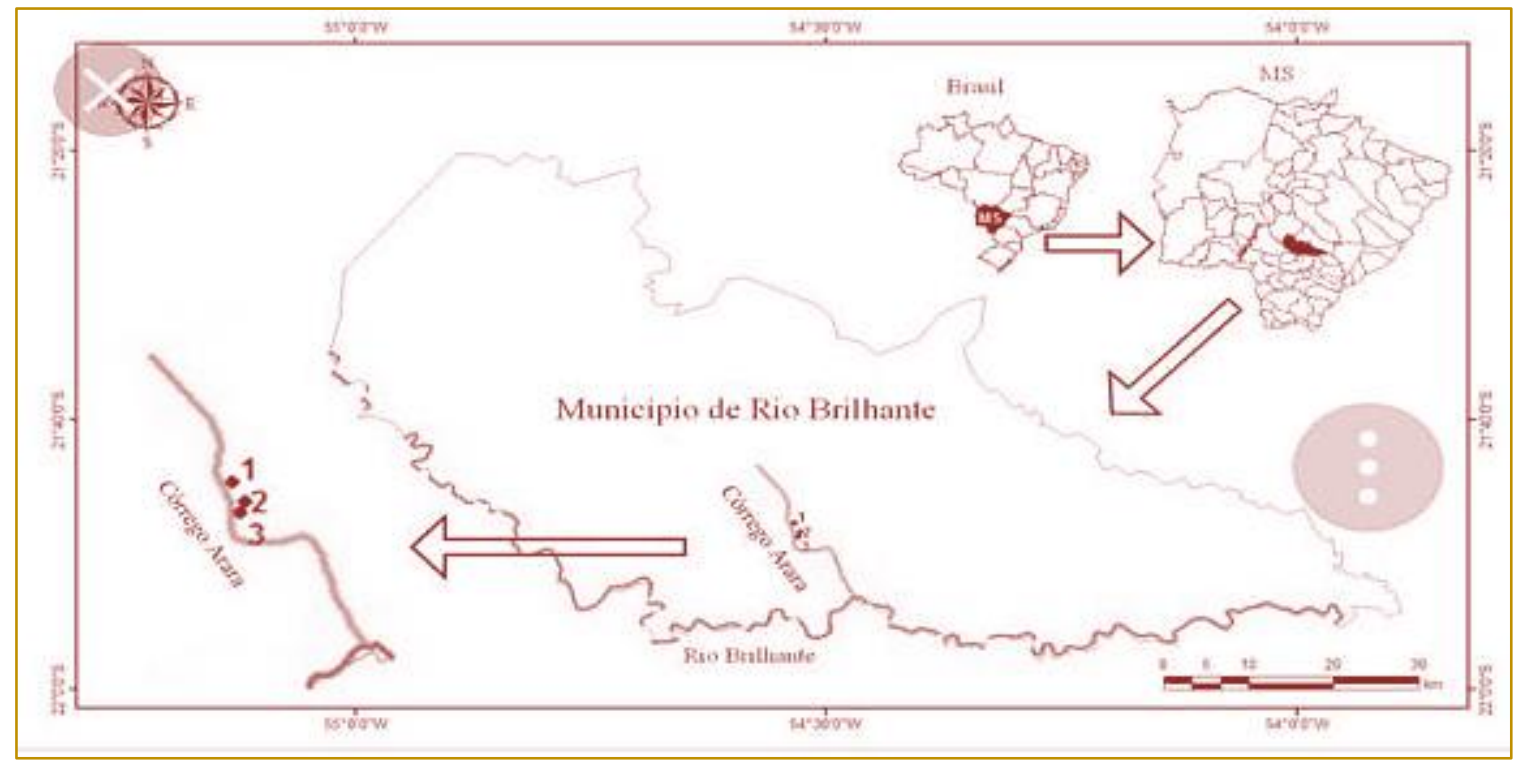

Fonte: Google Maps

Foi um projeto criado e reconhecido pelo INCRA, teve início em 1998, mas os lotes foram divididos em 12 de março de 1999. As terras do Assentamento foram das respectivas fazendas: Capão Redondo, Carrapicho, São Judas Tadeu e Salada, em uma área de 4.010,600 (ha.). Contemplou 187 famílias, possui uma área total de 4.000 hectares organizado em lotes com média de 13 hectares cada, formando 11 
pequenos grupos, que são demarcados por travessões. A área destinada ao assentamento São Judas foi desapropriada para atendimento de parte da demanda por terra, sendo fruto de uma negociação política entre o Instituto Nacional de Colonização e Reforma Agrária INCRA e antigos proprietários ${ }^{2}$. Vejamos o mapa do assentamento São Judas na figura 2:

Figura 2: Mapa do Assentamento São Judas

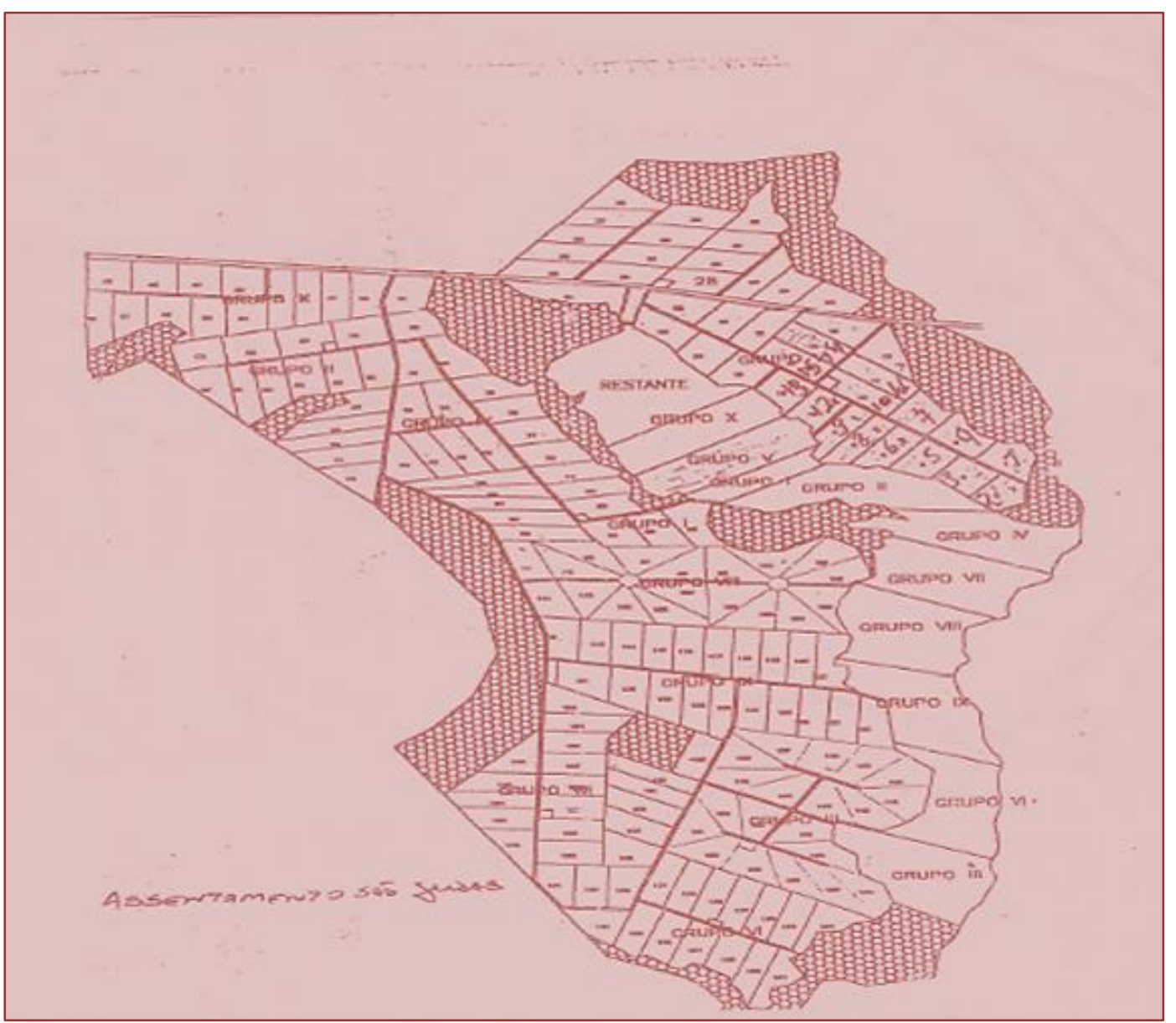

Fonte: INCRA

O Assentamento São Judas possui 187 lotes, alguns dos lotes estão arrendados, porém, na sua maioria, os camponeses produzem, tanto para o consumo da família como para venda, alguns encontram dificuldades na compra e venda porem a ligação que tem com a Terra faz com que permaneçam na luta diária por uma produção, na maioria das vezes, agroecológica, com diversidade, pois o objetivo de todos é exatamente esse: cultivar a terra, e é isso que estão fazendo, apesar das dificuldades encontradas no início e até hoje, mas, estão produzindo, tirando o sustento da família com produtos que vendem. De acordo com a nossa pesquisa, $60 \%$ dos entrevistados tem como principal fonte de renda o leite, $20 \%$ planta lavoura no seu lote, $10 \%$ cria gado de corte para vender e $10 \%$ tem como principal renda a criação de bicho da seda. Segue abaixo o gráfico 1 com a principal produção do lote dos entrevistados:

2Informação retirada do documentário: "mulheres assentadas: (re)construindo trajetórias". 
Gráfico 1- Principal atividade produtiva nos lotes no Assentamento São Judas.

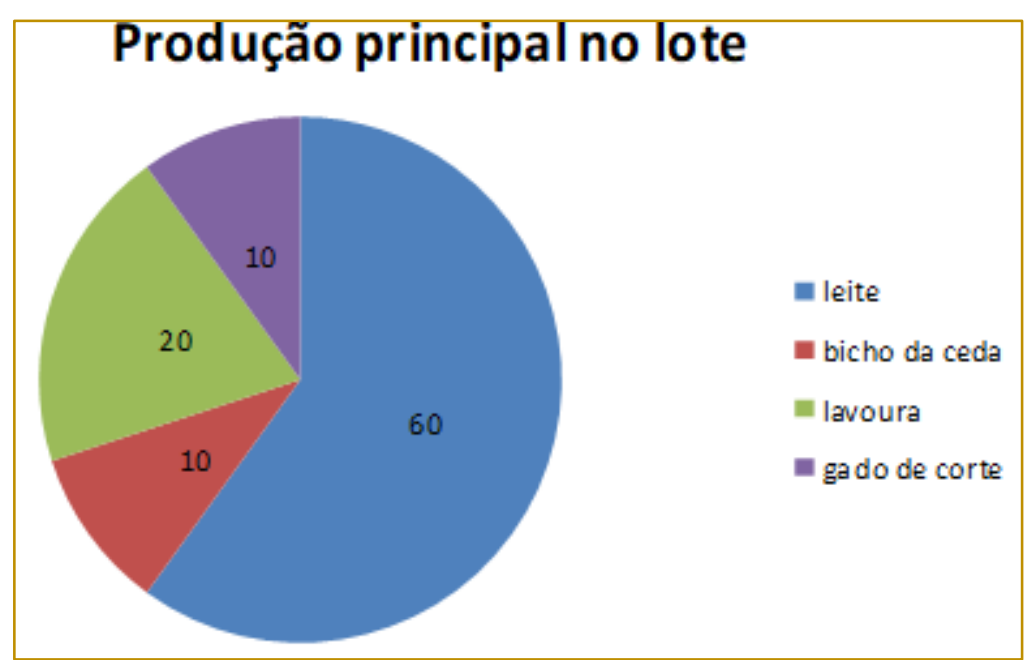

Fonte: Autora (2018).

Além da produção principal que gera renda, as famílias cultivam pequenas lavouras e criam animais para o autoconsumo: criação de galinhas, porcos e gado de corte para a subsistência, e acabam vendendo o excedente. Todos os entrevistados têm um pomar, e plantam algum tipo de alimento no lote, além de criação de animais, e alguns têm horta. Segue abaixo as figuras com as imagens das produções dos entrevistados (figuras 3, 4, 5, 6 e 7):

Figura 3-Criação de porcos pelos assentados.
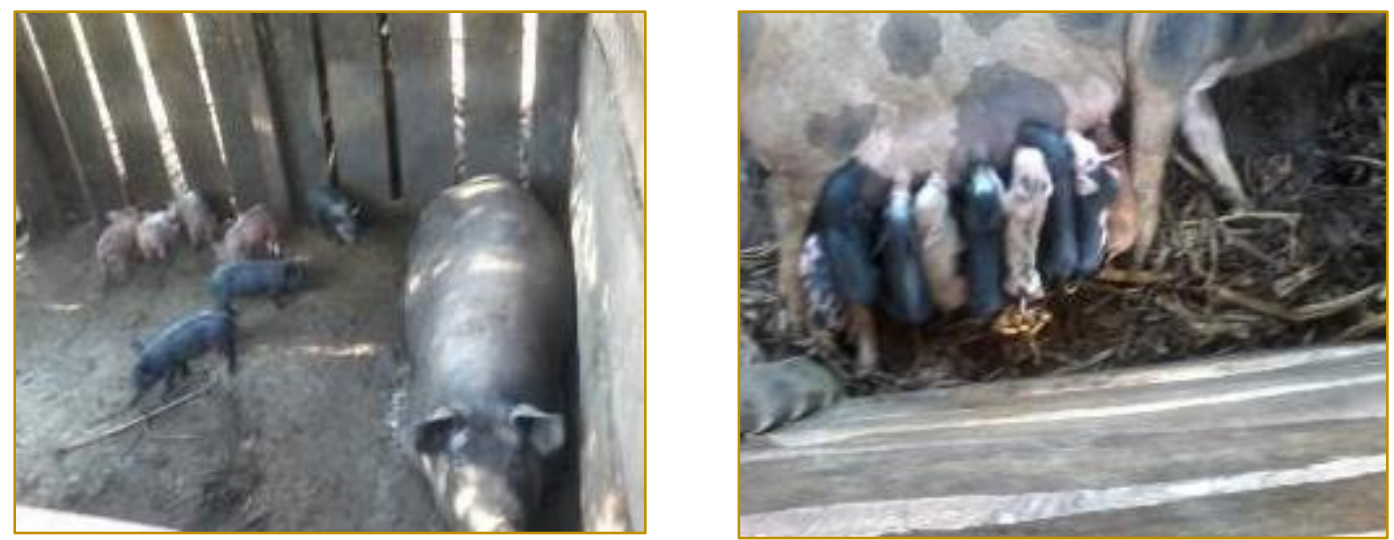

Fonte: Autora (2018) 
Figura 4: Lavoura para autoconsumo (amendoim, mandioca, batata doce) dos assentados.
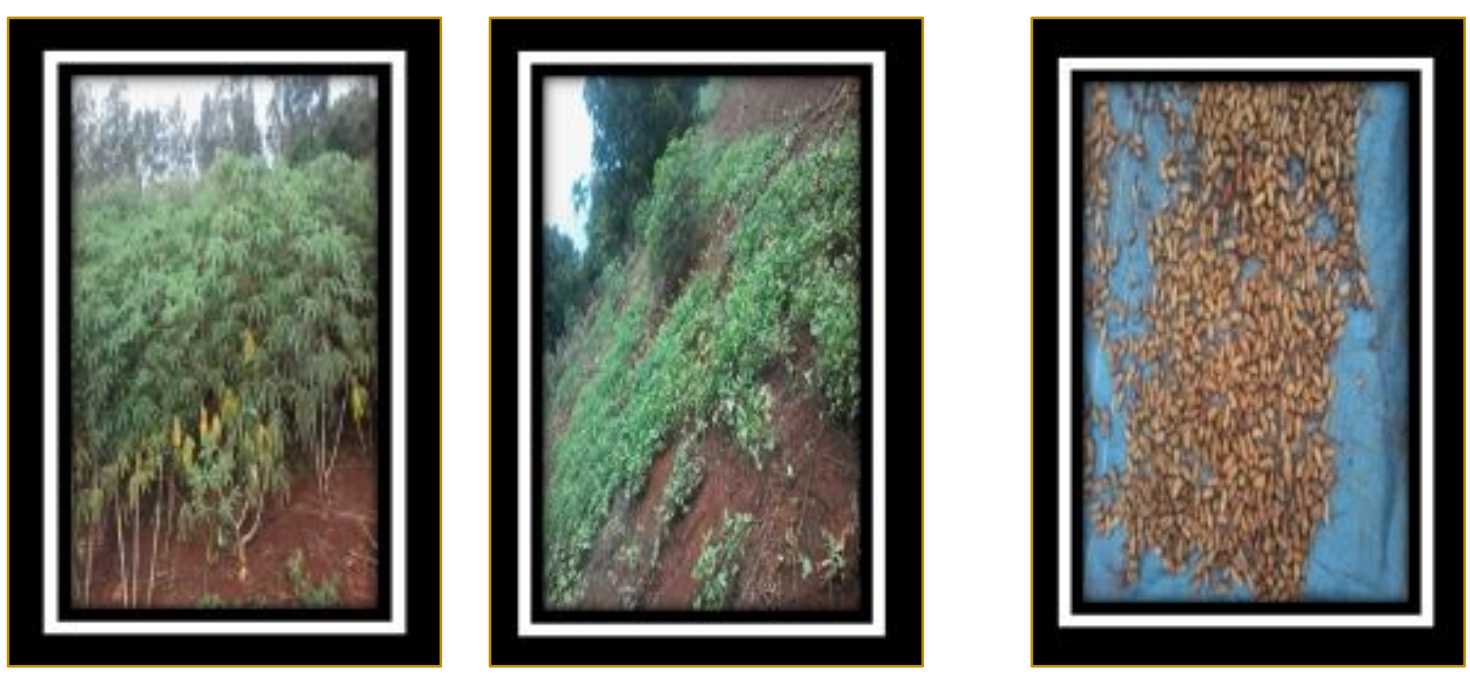

Fonte: Autora(2018).

Figura 5: Pomar de laranja, limão e mamão dos assentados.
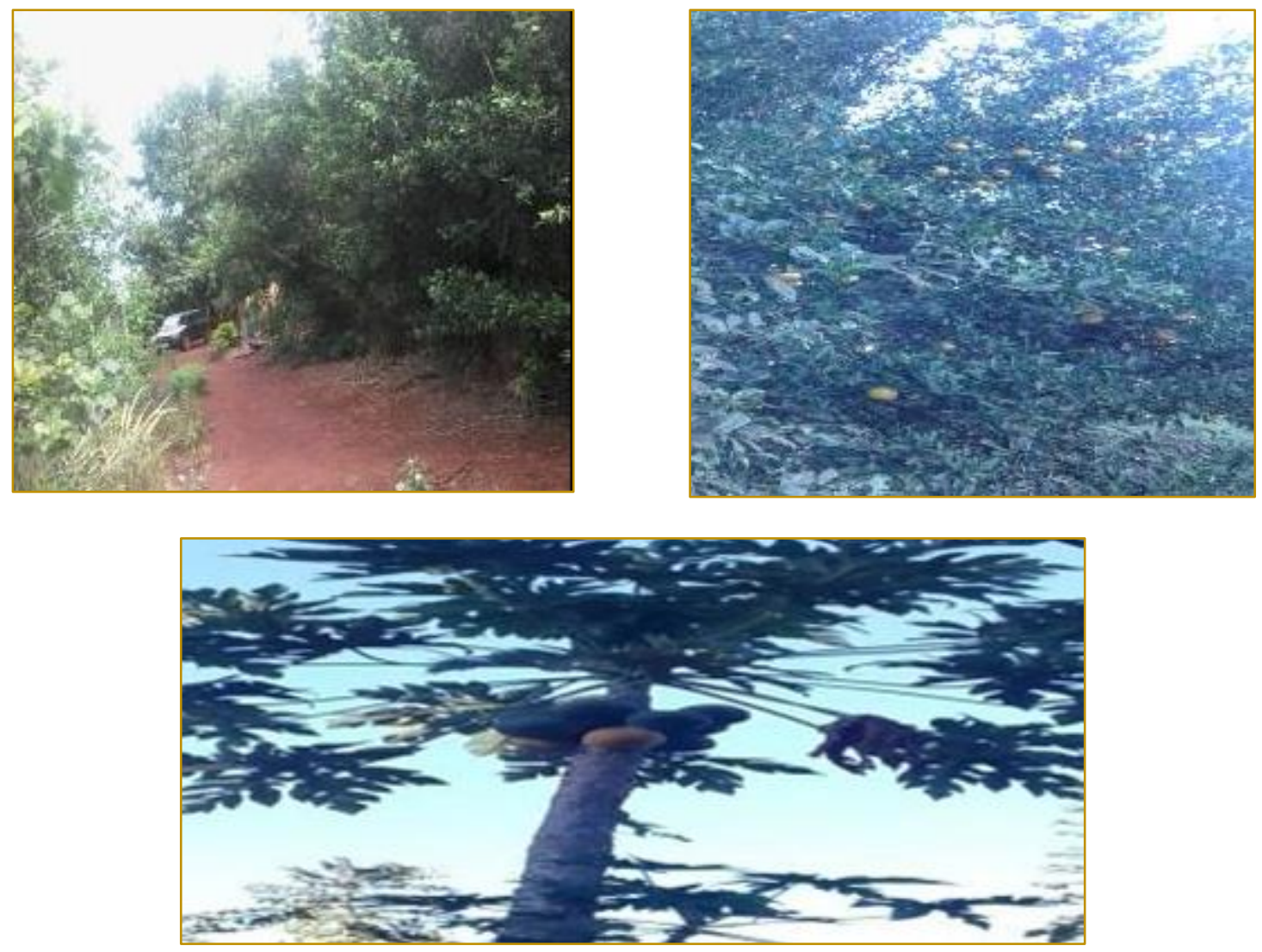

Fonte: Autora (2018). 
Figura 6: Criação de galinhas para o consumo dos assentados.
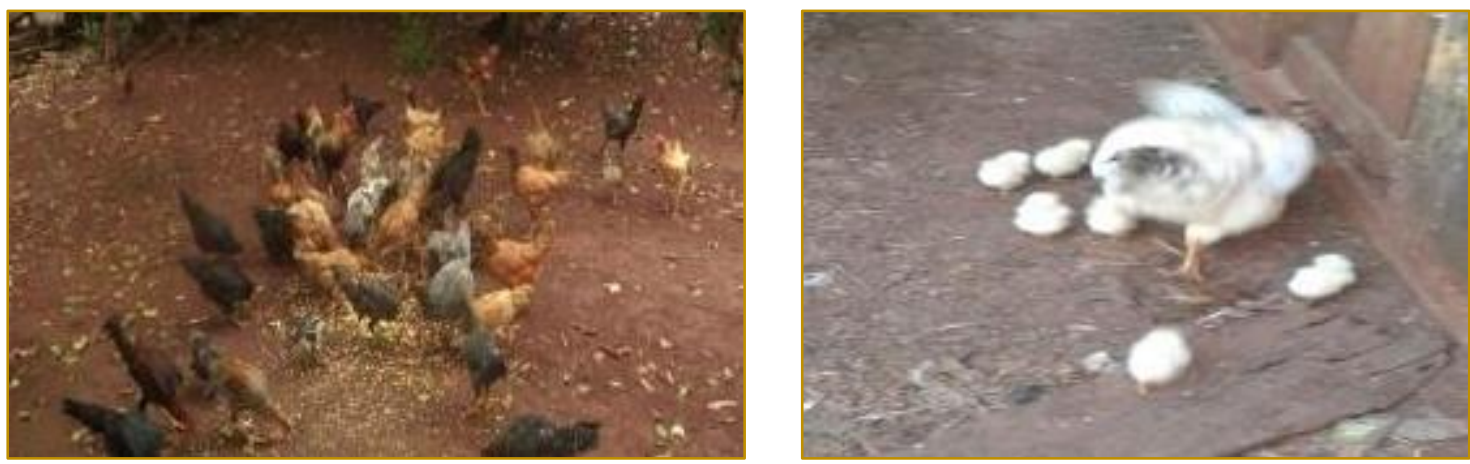

Fonte: Autora (2018).

Figura 7: Criação de vacas leiteiras pelos assentados.
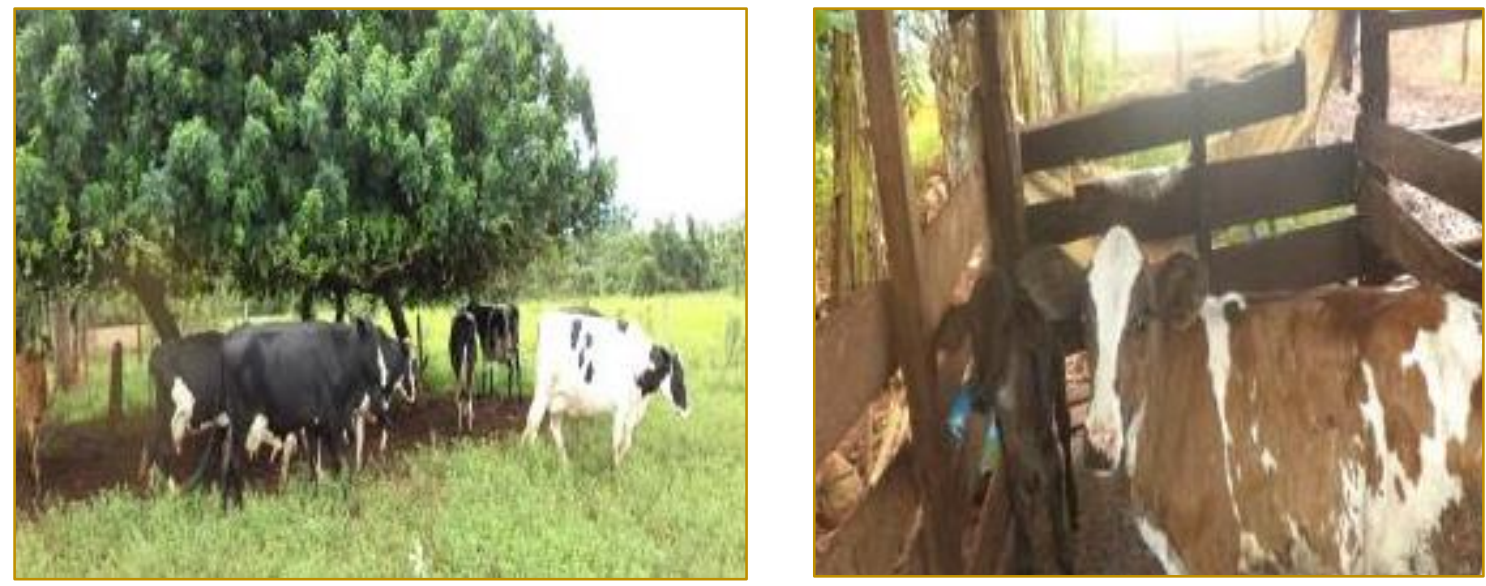

Fonte: Autora (2018).

Figura 8 - Hortas com produção de abóboras, alface, tomate, rúcula e cebolinha

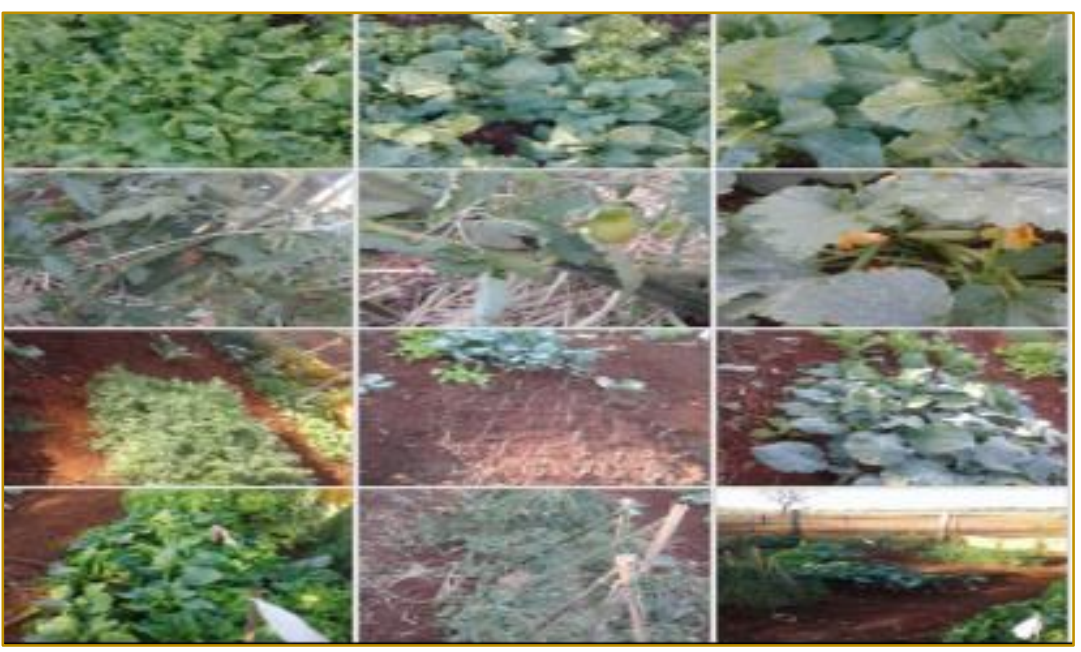

Fonte: Autora (2018). 
A renda familiar dos assentados varia de 2 salários mínimos a 4 salários mínimos. Entre os entrevistados, 5 deles, retiram a renda apenas do sítio, dentre estes, 4 famílias tem a documentação do INCRA e conseguiram acessar a linha de crédito, contam que isso ajudou muito no aumento da renda, pois investiram em melhorias no sítio (pastagens, correção de solo, vacas de leite e gado de corte).Todos aderiram ao Programa Nacional de Fortalecimento da Agricultura Familiar (PRONAF) ${ }^{3} \mathrm{~A}$ e estão em dia com o pagamento, pois se o produtor pagar certo as parcelas tem desconto de $40 \%$, o que facilita para o agricultor. As outras 5 famílias entrevistadas precisam complementar sua renda fora do lote, mas dentro do próprio assentamento, 3 dessas pessoas trabalham na escola, e outras 2 trabalham de diaristas para terceiros.

As famílias entrevistadas que estão devidamente documentadas pelo INCRA (5 famílias), todas acessaram a linha de crédito do PRONAF A ${ }^{4}$ e fizeram várias melhoras no sítio, atualmente o valor do PRONAF A é de $\mathrm{R} \$ 25.000,00$, com esse recurso, as famílias, fizeram a correção de solo, adubação em pastagens, melhorias nas cercas da propriedade e compraram vacas de leite e de corte, isso ajudou no aumento da renda. Dessas famílias, somente uma precisa complementar a renda fora da propriedade.

Mas, apesar de todas as dificuldades encontradas, seja com documentação irregular, falta de verba para melhorar o lote, dentre outras situações, todas as famílias relatam que preferem permanecer no lote, "pois é um lugar tranquilo, onde sabemos o que estamos comendo", diz o produtor 4.0u também, como diz a produtora 7: "é muito bom criar os filhos no campo para poder ensinar os valores que aprendi com meus pais". 0 produtor $10 \mathrm{diz}$ que "aqui a gente planta de tudo um pouco e não comemos as químicas que tem na cidade, a gente, às vezes, passa apertado, mas fome, jamais vamos passar”.

\section{CONCLUSÕES}

Este trabalho foi desenvolvido com o intuito de conhecer melhor a realidade das famílias do assentamento São Judas. Em todas as famílias é forte o desejo de ter um pedaço de terra para produzir o alimento mais saudável para a família, aqui no assentamento São Judas, as famílias residem no lote e vivem da agricultura com trabalho familiar, produzindo para vender e, também, para consumo da família.

Os lotes têm plantações diversificadas, como pomar, lavouras, horta e criação de animais. E apesar de todas as dificuldades encontradas, os agricultores assentados permanecem no lote porque possuem uma relação de identidade com a terra, pois a maioria dos entrevistados tem origem na agricultura e não quer deixar de viver e produzir no campo.

\section{REFERÊNCIAS}

[1] Brasil. Incra. DAP, é a declaração de Aptidão ao pronaf. Disponível em:<http://g1.globo.com/econimia/agronegocios/noticia/2013/02/dap-facilita-acesso-de-agricultores-familiaresao-credito-rural-html>. Acesso em: 10 ago. 2018.

[2] Brasil. Incra. Portaria do Incra/SR- 16/Nº 083/98, de 09 de outubro de 1998.

[3] Brasil. Incra. Regularização de lotes. Disponível em:<http://www.incra.gov.br/assentamento>. Acesso em 04 jul. 2018.

[4] Brasil. Ministério do Desenvolvimento Agrário-MDA, Instituto de Colonização e Reforma Agrária - INCRA, SuperIntendência Regional de Mato Grosso do Sul -SR(16).

[5] Brasil. Pronaf. Pronaf e Pronaf A. Disponível em: <http://www.bcb.gov.br/pre/bc_atende/port/PRONAF.asp>. Acesso em: 10 ago. 2018.

\footnotetext{
3 PRONAF destina-se a estimular a geração de renda e melhorar o uso da mão de obre familiar, por meio dofinanciamento de atividades e serviços rurais agropecuários e não agropecuários desenvolvidos em estabelecimento rural ou em áreas comunitárias próximas. Disponível em: <http://www.bcb.gov.br/pre/bc_atende/port/PRONAF.asp>. Acesso em: 10 ago. 2018.

${ }^{4}$ PRONAF A é o primeiro pronaf e quem pode aderir são agricultores familiares do Programa Nacional de Reforma Agrária (PNRA) ou do Programa de Crédito Fundiário (PNCF) enquadradas nos grupos "A" e "AC" do PRONAF. Disponível em:<http://www.bcb.gov.br/pre/bc_atende/port/PRONAF.asp>. Acesso em: 10 ago. 2018.
} 


\section{Bapítulo 8}

\section{ASPECTOS SOCIOECONÔMICOS DA AGRICULTURA URBANA EM BAIRROS CENTRAIS DE TRÊS LAGOAS, MS}

\section{Thomás Floriano Boscaine}

Ana Carolina Domingos Maluf

Clariana Vilela Borzone

Maria José Neto

Resumo: Por mais que hortas urbanas sempre estiveram presentes na sociedade, somente após 1990 os olhares se voltaram, uma vez que a urbanização tem ligação direta às altas taxas de pobreza e fome, e as hortas poderiam reverter esse panorama. Com isso maiores investimentos sobre a melhoria do quadro alimentar geral da população ganharam força, eis que há o fortalecimento da agroecologia. Com suas técnicas menos danosas ao meio ambiente e ao ser humano, ganhou destaque no que diz respeito à melhoria da condição da saúde social. 0 trabalho propõe o levantamento de hortas urbanas da região central de Três Lagoas, MS, e aplicação de questionário sobre temas agroecológicos que envolvem as hortas urbanas, a fim de promover os saberes da agroecologia, como também mensurar e classificar os conhecimentos prévios dos horticultores a respeito das técnicas alternativas de plantio. Os resultados obtidos possibilitaram a elaboração de tabelas a fim de elucidar e homogeneizar as respostas, para melhor entendimento do panorama de hortas urbanas na área estudada.

Palavras-chave: agricultura urbana; agroeocologia; hortas; agrotóxico; horticultores. 


\section{INTRODUCC̃̃O}

A agricultura urbana está presente desde os primórdios da existência de centros urbanos, e estende-se até hoje como prática cotidiana da sociedade. No entanto, é uma atividade agrícola desvalorizada, tanto economicamente, quanto a estudos acadêmicos de forma social direta. Somente após a década de 1990, mais precisamente em 1996 com a Conferência Habitat II - Conferência das Nações Unidas sobre Assentamentos Urbanos, maiores investimentos técnico e científico foram direcionados às práticas agrícolas urbanas, já que a elevada urbanização está intrinsicamente relacionada aos alarmantes índices de pobreza e insegurança alimentar (O'REILLY, 2014). De acordo com que CASTRO (1984) escreveu em seu livro Geografia da Fome, esta é uma consequência socioeconômica e política, não da insuficiência de alimentos. O Brasil está enquadrado entre os países com maior potencial produtor e exportador de produtos agrícolas, no entanto grande parcela da população não possui, ou possui precariamente, acesso a uma alimentação básica de qualidade (CANÇADO, et al., 2009). Afinal, em sociedades de mercado, que na maioria dos casos as pessoas encontram-se em estado de insegurança alimentar, alimentos são mercadorias, não sendo acessível plenamente pelos consumidores que não dispõem de recursos econômicos (ROCHA, et al., 2013). Analisando-se os quadros agrícolas de novas experiências alternativas de produção de alimentos, constatou-se que a agroecologia já vinha sendo aplicada cientificamente em solos brasileiros desde a década de 1970. Ciência essa que parte "da ideia de reforma desses antigos sistemas de entendimento e explicação da realidade, aderidos a uma racionalidade econômicoinstrumental, postos à prova e questionados quando da incapacidade de responderem aos complexos problemas de ordem socioambiental derivados da radicalização dos riscos da sociedade moderna industrial" (FLORIANI\&FLORIANI, 2010). Com isso, partindo desse pressuposto, a agroecologia possui enorme aporte à segurança alimentar, entendida conforme o que diz a Lei no 11.346, de 15/09/06. Art. 3o - "a segurança alimentar e nutricional consiste na realização do direito de todos ao acesso regular e permanente a alimentos de qualidade, em quantidade suficiente, sem comprometer o acesso a outras necessidades essenciais, tendo como base práticas alimentares promotoras da saúde, que respeitem a diversidade cultural e que seja ambiental, cultural, econômica e socialmente sustentável".

Desta forma, tendo como perspectiva o aumento significativo dos conceitos e saberes agroecológicos nas áreas urbanas centrais do município de Três Lagoas, MS, o trabalho propõe uma identificação do conhecimento prévio dos horticultores sobre a agroecologia em suas mais diversas faces, tanto no que se enquadra como conhecimentos sociais, e conhecimentos técnicos relacionados à produção e cultivo de alimentos, assim como uma abordagem informativa sobre vertentes do pensamento agroecológico, por exemplo, como "estudos têm medido o impacto ambiental e social da intensificação agroquímica nos ecossistemas da América Latina. Aponta-se para cifras que superam 10 bilhões de dólares por ano quantificando-se os custos ambientais da contaminação de águas e solos, danos à vida silvestre e o envenenamento de pessoas; não incluindo ainda os impactos ambientais associados (contaminação de águas por nitrato, eutrofização dos rios e lagos, entre outros) com o incremento do uso de fertilizantes nitrogenados nem tampouco os problemas de salinização ligados à irrigação em zonas não apropriadas." (FLORIANI\&FLORIANI, 2010).

\section{METODOLOGIA}

0 trabalho foi desenvolvido em duas etapas, a primeira envolvendo o levantamento de hortas urbanas presentes na região central de Três Lagoas, a escolha das hortas a serem analisadas e o estudo das práticas de agricultura urbana nas mesmas. Foram levantadas $10(\mathrm{dez})$ hortas urbanas na região central de Três Lagoas, MS, sendo que houve o trabalho efetivo realizado em apenas 06 (seis) devido a desencontros de horários, desinteresse dos proprietários com o trabalho proposto e até mesmo desconhecimento e falta de acessibilidade aos mesmos. Não se consideraram as hortas presentes nos cinturões verdes, distritos rurais, pequenas propriedades rurais e nos assentamentos rurais, atualmente principais responsáveis pelo fornecimento de alimentos agroecológicos para abastecimento local da cidade, em sua maioria através de mercados estatais como o Programa Nacional de Alimentação Escolar e o Programa de Aquisição de Alimentos. Também não se consideraram as hortas domésticas não-comerciais.

A segunda etapa deu-se a partir da aplicação de um questionário aos horticultores com 23 (vinte e três) questões, divididas em dezenove (19) questões de múltipla escolha e quatro (4) questões discursivas. Tais perguntas tentam por sua vez transparecer a realidade dos horticultores em relação às dificuldades por eles enfrentadas, seja pela falta de auxílio governamental, interesses acadêmicos, desconhecimento de novas técnicas agrícolas ou até mesmo o descaso da comunidade para com os alimentos cultivados. 0 questionário baseado em ARRUDA et al. (2005) apresenta funcionalidade em contabilizar as semelhantes 
dificuldades e salientar os problemas a fim de encontrar soluções eficazes para melhorias tanto na produção, cultivo e manejo, quanto para a comercialização dos alimentos, uma vez que a agroecologia visa não somente a melhores colheitas, mas também à maior acessibilidade da população a produtos de melhor qualidade nutritiva.

\section{RESULTADOS E DISCUSSÃO}

O levantamento realizado permitiu a coleta de dados de 06 proprietários de hortas na região central de Três Lagoas, MS, cujos dados se encontram distribuídos em duas tabelas para melhor visualização e comparação das variáveis apresentadas. A Tabela 1 diz respeito às questões sociais, econômicas, históricas e culturais dos proprietários entrevistados. A Tabela 2 condiz ao levantamento dos produtos cultivados em cada horta pesquisada, mostrando o quão homogêneas são as produções, por mais distintos que sejam as técnicas e o perfil dos proprietários. Com isso, a interpretação que se dá, é que há certa padronização no cultivo de alimentos, com o enfoque principal nas hortaliças e em grande escala, não sobrando espaço e nem interesse em outros tipos de vegetais, como os legumes ou tubérculos.

Tabela 1. Aspectos socioeconômicos dos horticultores entrevistados na região central de Três Lagoas, MS.

\begin{tabular}{|c|c|c|c|c|c|c|}
\hline Nome & H1 & H2 & H3 & $\mathrm{H} 4$ & H5 & H6 \\
\hline Tempo & 31 anos & 14 anos & 07 anos & 02 anos & 09 anos & 20 anos \\
\hline Histórico & Sim & Sim & Iniciante & Sim & Iniciante & Iniciante \\
\hline Meio de Vida & Sim & Parcial & Sim & Sim & Sim & Sim \\
\hline $\begin{array}{c}\text { Perfil do } \\
\text { consumidor }\end{array}$ & $\begin{array}{l}\text { Pequeno e } \\
\text { grande } \\
\text { consumidor }\end{array}$ & $\begin{array}{c}\text { Grande } \\
\text { consumidor }\end{array}$ & $\begin{array}{l}\text { Pequeno e } \\
\text { grande } \\
\text { consumidor }\end{array}$ & $\begin{array}{l}\text { Pequeno e } \\
\text { grande } \\
\text { consumidor }\end{array}$ & $\begin{array}{l}\text { Pequeno } \\
\text { consumidor }\end{array}$ & $\begin{array}{l}\text { Pequeno e } \\
\text { grande } \\
\text { consumidor }\end{array}$ \\
\hline $\begin{array}{c}\text { Relação } \\
\text { comunidade }\end{array}$ & Financeira & $\begin{array}{l}\text { Interação } \\
\text { social }\end{array}$ & $\begin{array}{c}\text { Interação } \\
\text { social }\end{array}$ & Financeira & $\begin{array}{l}\text { Interação } \\
\text { Social }\end{array}$ & $\begin{array}{l}\text { Interação } \\
\text { Social }\end{array}$ \\
\hline $\begin{array}{l}\text { Alimentação } \\
\text { familiar }\end{array}$ & Parcial & Parcial & Parcial & Parcial & Parcial & Parcial \\
\hline $\begin{array}{l}\text { Auxílio } \\
\text { familiar }\end{array}$ & $\begin{array}{c}\text { Pouca } \\
\text { participação } \\
\text { familiar }\end{array}$ & $\begin{array}{c}\text { Pouca } \\
\text { participação } \\
\text { familiar }\end{array}$ & $\begin{array}{l}\text { De toda } \\
\text { família }\end{array}$ & $\begin{array}{l}\text { De toda } \\
\text { família }\end{array}$ & $\begin{array}{l}\text { De toda } \\
\text { família }\end{array}$ & $\begin{array}{c}\text { Pouca } \\
\text { participação } \\
\text { familiar }\end{array}$ \\
\hline $\begin{array}{c}\text { Fase inicial da } \\
\text { produção }\end{array}$ & $\begin{array}{l}\text { Compra de } \\
\text { mudas e } \\
\text { viveiro } \\
\text { próprio }\end{array}$ & $\begin{array}{l}\text { Compra de } \\
\text { mudas }\end{array}$ & $\begin{array}{l}\text { Compra de } \\
\text { mudas }\end{array}$ & $\begin{array}{l}\text { Compra de } \\
\text { mudas e } \\
\text { algumas } \\
\text { sementes }\end{array}$ & $\begin{array}{l}\text { Compra de } \\
\text { mudas e } \\
\text { viveiro } \\
\text { próprio; }\end{array}$ & $\begin{array}{l}\text { Compra } \\
\text { muda }\end{array}$ \\
\hline Agrotóxicos & Sim & Sim & $\operatorname{Sim}^{5}$ & $\begin{array}{c}\text { Sim } \\
\text { (mulching) }\end{array}$ & Orgânico & Orgânico \\
\hline $\begin{array}{l}\text { Calendário de } \\
\text { cultivo }\end{array}$ & Não segue & Não segue & Não segue & Não segue & Não segue & Não segue \\
\hline Área & $3.000 \mathrm{~m}^{2}$ & $50.000 \mathrm{~m}^{2}$ & $400 \mathrm{~m}^{2}$ & $1.000 \mathrm{~m}^{2}$ & $1.000 \mathrm{~m}^{2}$ & $2.000 \mathrm{~m}^{2}$ \\
\hline Ampliação & Sim & Sim & Não & Sim & Não & Não \\
\hline Mão de Obra & Alto & Alto & Moderado & Alto & Moderado & Alto \\
\hline $\begin{array}{c}\text { Retorno } \\
\text { financeiro }\end{array}$ & Moderado & Moderado & Moderado & Baixo & Moderado & Baixo \\
\hline Posse da terra & $\begin{array}{l}\text { Segurança } \\
\text { alta }\end{array}$ & $\begin{array}{l}\text { Segurança } \\
\text { baixa }\end{array}$ & $\begin{array}{l}\text { Segurança } \\
\text { baixa }\end{array}$ & $\begin{array}{l}\text { Segurança } \\
\text { baixa }\end{array}$ & $\begin{array}{c}\text { Segurança } \\
\text { baixa }\end{array}$ & $\begin{array}{c}\text { Segurança } \\
\text { baixa }\end{array}$ \\
\hline $\begin{array}{l}\text { Apoio do } \\
\text { Governo }\end{array}$ & Não & Não & Não & Não & Não & Não \\
\hline $\begin{array}{l}\text { Pesquisa e } \\
\text { Extensão }\end{array}$ & Não & Sim & Não & Não & Não & Não \\
\hline $\begin{array}{c}\text { Parceria } \\
\text { universitário }\end{array}$ & A conversar & Sim & A conversar & A conversar & Sim & A conversar \\
\hline Agroecologia & Razoável & Pouco & Pouco & Razoável & Razoável & Muito \\
\hline PANCs & Pouco & Pouco & Nenhum & Razoável & Razoável & Pouco \\
\hline Orgânicos & Razoável & Razoável & Nenhum & Pouco & Muito & Muito \\
\hline
\end{tabular}

Fonte: Dados da pesquisa dos autores

50 proprietário garantia que não utilizava agrotóxicos, somente uma substância que deixava o "mato" amarelo. 
Tabela 2. Produtos cultivados nas hortas encontradas na região central de Três Lagoas, MS.

\begin{tabular}{|l|c|c|c|c|c|c|}
\hline \multicolumn{1}{|c|}{ Nome } & $\mathrm{H} 1$ & $\mathrm{H} 2$ & $\mathrm{H} 3$ & $\mathrm{H} 4$ & $\mathrm{H}$ & $\mathrm{H}$ \\
\hline Agrião & & $\mathrm{X}$ & & & & \\
\hline Alface & $\mathrm{X}$ & $\mathrm{X}^{6}$ & $\mathrm{X}$ & $\mathrm{X}$ & $\mathrm{X}$ & $\mathrm{X}$ \\
\hline Almeirão & $\mathrm{X}$ & $\mathrm{X}$ & & & $\mathrm{X}$ & $\mathrm{X}$ \\
\hline Brócolis & $\mathrm{X}$ & & & & & \\
\hline Cebolinha & $\mathrm{X}$ & $\mathrm{X}$ & $\mathrm{X}$ & $\mathrm{X}$ & $\mathrm{X}$ & $\mathrm{X}$ \\
\hline Coentro & $\mathrm{X}$ & $\mathrm{X}$ & & & $\mathrm{X}$ & $\mathrm{X}$ \\
\hline Couve & $\mathrm{X}$ & $\mathrm{X}$ & $\mathrm{X}$ & $\mathrm{X}$ & $\mathrm{X}$ & $\mathrm{X}$ \\
\hline Couve-flor & $\mathrm{X}$ & & & & & \\
\hline Escarola & & & & & & $\mathrm{X}$ \\
\hline Espinafre & & $\mathrm{X}$ & & & & $\mathrm{X}$ \\
\hline Hortelã & & $\mathrm{X}$ & & & $\mathrm{X}$ & \\
\hline Mostarda & & $\mathrm{X}$ & & & & \\
\hline Rúcula & $\mathrm{X}$ & $\mathrm{X}$ & $\mathrm{X}$ & $\mathrm{X}$ & $\mathrm{X}$ & $\mathrm{X}$ \\
\hline Salsinha & $\mathrm{X}$ & $\mathrm{X}$ & $\mathrm{X}$ & $\mathrm{X}$ & $\mathrm{X}$ & $\mathrm{X}$ \\
\hline
\end{tabular}

Fonte: Dados da pesquisa dos autores.

\section{CONSIDERAÇÕES FINAIS}

A agricultura urbana, por mais ínfima que ainda possa ser, promove o sustento de muitas famílias, sejam elas proprietárias da terra, funcionários das hortas ou até mesmo consumidores que não possuem condições de dirigirem-se aos mercados. Contudo, há de se preocupar com a falta de incentivo governamental para com os horticultores, assim como a falta de interesse da comunidade agrícola urbana para com alimentos isentos de agrotóxicos. Por mais que estes muitas vezes compreendam os malefícios do uso de tais substâncias, dizem não ter as condições necessárias para a transição do meio de cultivo convencional para o orgânico. Outros, mesmo fazendo uso de agrotóxicos, dizem-se produtores orgânicos, revelando mais uma vez a falta de instrução para com os conceitos agroecológicos.

\section{REFERÊNCIAS}

[1] Arruda, J., Arraes, N. A. M. Agricultura Urbana e Peri-urbana em Campinas: subsídios para políticas públicas. Sociedade Brasileira de Economia e Sociologia Rural, Ribeirão Preto/SP, 2005.

[2] Brasil. Lei n.o 11.346, de 15 de setembro de 2006. Cria o Sistema Nacional de Segurança Alimentar e Nutricional - SISAN com vistas em assegurar o direito humano à alimentação adequada e dá outras providências. Diário Oficial da União - Seção 1 - 18/9/2006, Página 1. Brasília, DF, 25 de agosto de 2010.

[3] Cançado, A. C., Finco, M. V. A., Finco, F. D. B. A., Cançado, A. C. M. G. Economia Solidária e Desenvolvimento Sustentável: resultados da atuação do NESol/UFT no Bico do Papagaio/TO. Graffset Gráfica e Editora LTDA, Goiânia/GO, 2009.

[4] Castro, J. Geografia da fome: o dilema brasileiro - pão ou aço. Editora Antares Achiamé. Rio de Janeiro/RJ, 1984.

[5] Floriani, N., Floriani, D. Saber Ambiental Complexo: aportes cognitivos ao pensamento agroecológico. Revista Brasileira de Agroecologia. Porto Alegre/RS, 2010.

[6] O'reilly, E. M. Agricultura Urbana - Um Estudo de Caso do Projeto Hortas Cariocas em Manguinhos, Rio de Janeiro. UFRJ/Escola Politécnica, Rio de Janeiro/RJ, 2014.

[7] Rocha, C., Burlandy, L., Magalhães, R. Segurança alimentar e nutricional: perspectivas, aprendizados e desafios para as políticas públicas. Editora Fiocruz, Rio de Janeiro/RJ, 2013.

${ }^{6} 0$ proprietário cultiva três variedades: a alface americana, a crespa e a roxa. 


\section{Bapítulo 9}

\section{SISTEMAS DE PRODUCCIÓN DE CAFÉ ORGÁNICO EN CHIAPAS, MÉXICO}

\section{Etztli Itzel Morales Reyes}

Miguel Ángel Balderas Plata

Salvador Adame Martínez

María Raimunda Araújo Santana

Resumen: El café es el primer producto agroalimentario en México, tiene un alto impacto económico, social y ambiental, de él dependen casi cinco millones de mexicanos, la mayoría pequeños productores orgánicos con cultivos no mayores 5 ha. El objetivo de este trabajo es conocer las problemáticas de los sistemas de producción orgánico de café, en una asociación en cuatro municipios del Estado de Chiapas.Para esta investigación se realizó; La caracterización de los sistemas de producción de café de la asociación Nubes de Oro y un diseño longitudinal de tendencia, con la revisión los datos que se obtuvieron a través de informes de certificación orgánica de los ciclos desde el 2012 al 2016, los documentos de inspección interna y seguimiento de productores de la asociación. Este trabajo servirá para proponer soluciones a problemáticas que presenta la producción de café orgánico en esta región.

Palabras Clave: Cafeticultura; Agricultura Orgánica; Agricultura familiar; Certificación orgánica; Pequeños productores. 


\section{INTRODUCCIÓN}

El estado de Chiapas se encuentra al sureste de México y tiene una extensión territorial de $73670 \mathrm{k}^{2}$, representa aproximadamente $3.8 \%$ de la superficie total del país. Entre las principales actividades del estado se encuentra la agricultura y la ganadería, donde el café es uno de los productos de mayor importancia económica y social, ya que genera entre 250 y 300 millones de dólares anuales, (VILLAFUERTE Y GARCÍA, 2006; MESTRIES, 2003). El café, es uno de los productos más sensibles para las familias campesinas, ya que está expuesto a las variaciones de los precios internacionales y a una estructura de intermediación que se apropia de los excedentes generados por los pequeños productores. Como resultado a lo anterior, es importante conocer las problemáticas que existen en los sistemas de producción esto ayudara a mejorar la capacitación, la extensión agroecológica, tener mejores rendimientos, disminuir los costos de producción, y conservar la biodiversidad (MÉNDEZ, 2013).

\section{MATERIALES Y MÉTODOS}

Para el desarrollo de esta investigación se realizó; La caracterización de los sistemas de producción de café de la asociación Nubes de Oro: Ubicación, estructura de organización y participación, descripción del manejo del cultivo de café, mercado y comercialización A partir de la caracterización se identificaron algunas debilidades en la asociación posteriormente se porcedio a realizar un diseño longitudinal de tendencia con la revisión de informes de certificación orgánica de los ciclos de producción desde el 2012 al 2016, los documentos de inspección interna y seguimiento de productores de la asociación, además se realizaron dos reuniones con el consejo administrativo y técnico en las instalaciones de la Asociación Nubes de Oro en las cuales expresaron algunas fragilidades que enfrentan. Así mismo se consideraron factores externos que podrían incrementar el riesgo y la vulnerabilidad.

\section{RESULTADOS Y DISCUSIÓN}

\subsection{CARACTERIZACIÓN DE LA ASOCIACIÓN NUBES DE ORO}

La asociación se localiza alrededor de la Reserva de la Biosfera El Triunfo, del lado de la vertiente del pacifico (Figura 1), Nubes de Oro, esta situada en la región económica Istmo-Costa y Soconusco distribuida en 4 municipios Pijijiapan, Mapastepec, Acacoyagua y Huixta, se encuentra en áreas con vegetación de selvas caducifolias y perenifolias, así como bosques de pino encino en las partes altas. Los suelos predominantes son cambisoles y vertisoles, con condiciones propicias para el buen desarrollo de café, se encuentran entre los 900 y 120 msnm.

El objetivo de esta asociación, es la producción, certificación y comercialización de café orgánico. La visón de Nubes de Oro es tener sistemas agrícolas sustentables que optimicen y estabilicen la producción, promover el comercio justo, la equidad de género, preservar la identidad, la cultura y la aplicación de conocimientos tradicionales (ver, Anexo 1). La experiencia de los socios en la producción de café es de más de 20 años, pero fue hasta el 2001 cuando se empezó a trabajar en el proceso de certificación y se realizaron las primeras ventas de café. Actualmente se cuenta con 366 socios de los cuales 291 hombres y 75 mujeres.

Los representantes legales y el consejo de administración está integrado por un presidente, un secretario y un tesorero. 
Figura 1. Mapa de ubicación

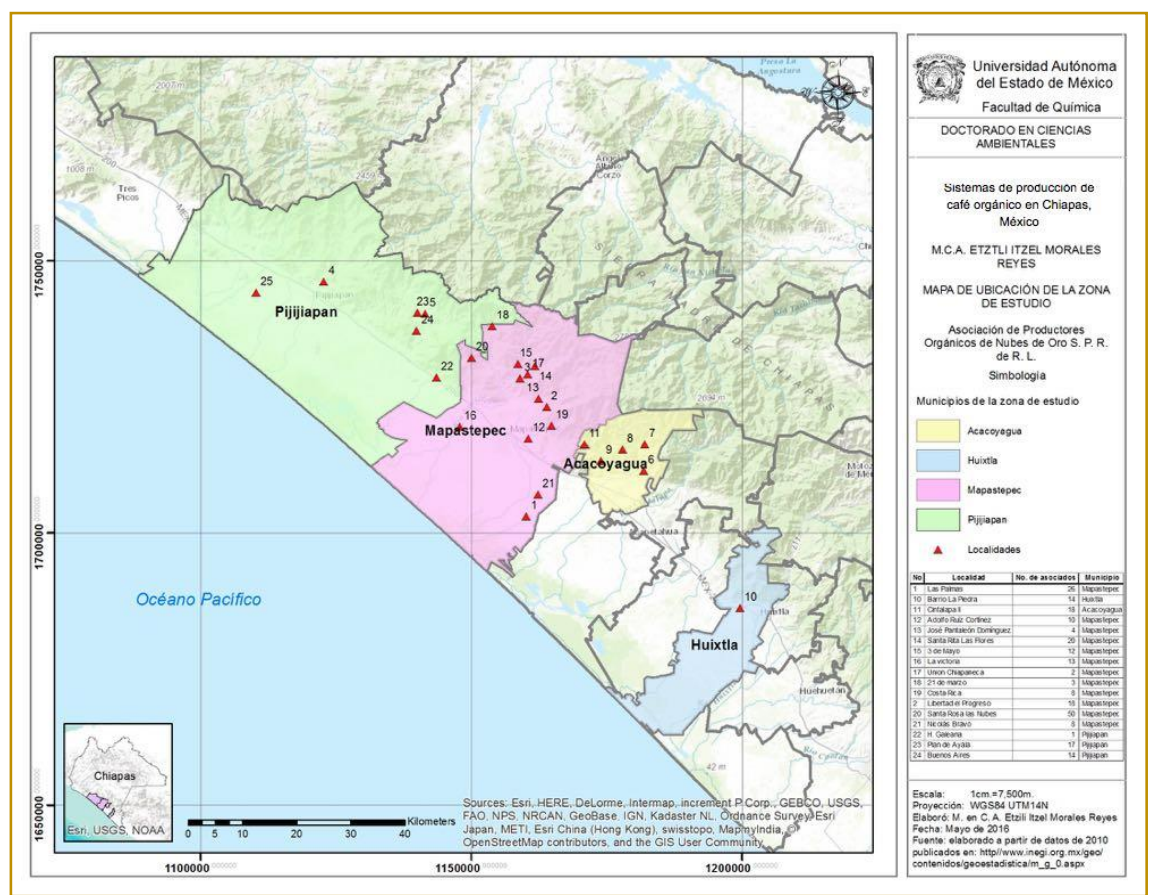

La asociación cuenta con una programación anual de capacitación a través de cursos. La participación de productores es de suma importancia para el cumplimento de los criterios de: Certificación orgánica; Café de sombra del Smithsonian Migratory Bird Center (CMBC); Comercio justo. A continuación se mencionan algunos de los cursos.

1. Manejo de Cafetales: donde se muestra el control y la conducción de la producción orgánica de café.

2.Vivero de café: Capacitación para la instalación de viveros para la producción de cafetos de las variedades, Catimor, Salchimor, Colombia y Oro Azteca, introducción de variedades resistentes a plagas y enfermedades principalmente a de roya (Hemileia vastatrix )y broca del café (Hypothenemus hampei).

3. Fertilización: Uso de abonos orgánicos, productos prohibidos en la agricultura orgánica.

4. Control de plagas y enfermedades: Elaboración de repelentes, caldo bordelés y sulfocalsico, productos comerciales.

5. Beneficiado: Explicación del beneficiado húmedo y seco.

6. Tratamiento de aguas residuales: Instalación del equipo de aguas residuales, inspeccionar que los equipos se encuentren en buen estado, preparación de las despulpadoras.

7. Catación: Clasificaciones de calidad, atributos del café de calidad, dar a conocer las características que el mercado de café exige, promover mejorar la calidad.

8. Seguridad alimentaria: Curso de producción de aves, porcinos y ovinos, establecimiento de hortalizas, para consumo familiar.

9. Nutrición e higiene: aprovechamiento de los productos de la finca, inocuidad en la manipulación de estos.

10. Foro de café: dar a conocer a los socios las actividades realizadas, los acuerdos, financiamientos y las actividades para el siguiente ciclo de producción, propuestas de cursos según los intereses de los cafeticultores. 


\section{Descripción del manejo del cultivo de café}

Enseguida se presentan los cuadros con la descripción del proceso de manejo del cultivo.

Especies y variedades cultivadas

Propagación

Sombra

Manejo de Malezas

Manejo del Tejido.

Manejo de la

fertilidad de Suelos

Conservación del suelo

Manejo de Plagas y enfermedades

Cosecha.
Café árabe lavado (coffea arabica L.), dentro del café árabe se cultivan diversas variedades, las mas importantes son: Typica (criollo o árabe), Bourbon y Mundo Novo. Las variedades tradicionales que han mostrado mayor calidad física y sensorial es variedad Typica y sus derivados Pluma Hidalgo, Blue Mountain, Maragogype aunque todas susceptibles a roya.

La semilla se obtiene de plantas seleccionadas de la misma finca orgánica, pero cuando esto no es posible entonces se puede adaptar de otras plantaciones, siempre y cuando la semilla no haya sido tratado con productos químicos. Es importante realizar una buena selección de los materiales para siembra ya sea semilla, pesetilla o planta, para evitar una mala germinación, esto asegura contar con plantas vigorosas y sanas que son fundamentales para la futura plantación.

La organización se basa en el cultivo bajo sombra, de esta manera se evita la deforestación, se protege el suelo de la erosión, se reducen las variaciones de temperatura, se conserva la humedad, el desarrollo de las hierbas se reduce y se contribuye al mantenimiento de la fertilidad de los suelos. Considera la conservación de los cafetales rusticanos o de montaña que mantienen vegetación nativa, que son frecuentes en los cafetales de Chiapas. La sombra debe reunir los criterios biofísicos que estipulan las normas del café de sombra del Smithsonian Migratory Bird Center (CMBC),

Las técnicas de manejo de malezas consideran el control cultural mediante el uso de arboles de sombra, cobertura muerta (residuos de cosechas, zacate picado, bagazo de caña, hierbas etc.), coberturas vivas (principalmente leguminosas nativas, comelinas, cacahuate forrajero, etc.) y cultivos asociados. El control manual o mecánico se realiza con machete entre 5 y $10 \mathrm{~cm}$.

Esta practica se considera fundamental para incrementar la productividad de los cafetales orgánicos. Se recomienda realizar una selección individual de los cafetos que requieren poda parcial o recepa. En la poda parcial se eliminan algunos tallos o ramas que están agotados, enfermos, secos o quebrados. Los cafetos con un aspecto de intensa descompensación con problemas nutricionales y fitosanitarios pero que aun conservan un sistema radical sano y vigoroso, por lo que se aplica una poda profunda o de rejuvenecimiento.

La fertilización orgánica tiene como propósito contribuir en la conservación y mejoramiento de la fertilidad natural del suelo, para que este tenga la capacidad suficiente de proveer los nutrientes necesarios al crecimiento y producción de los cafetos.

Los abonos orgánicos deben ser aplicados en el periodo de lluvias y una sola vez al año, en cantidades que varían al tipo de plantación y condiciones del suelo, para mejor aprovechamiento se recomienda aplicarlos sobre las terrazas en terrenos con declive y en terrenos planos depositarlos en las cajuelas. La aplicación de abono orgánico es la forma que más se ha recomendado y que mas se utiliza para mantener y mejorar la fertilidad de lo suelos, de composta producida en aboneras orgánicas se aplican de 3 a $10 \mathrm{~kg}$ de abono, por planta cada año o bien cada 2 años.

La protección del suelo se realizan a través de técnicas agronómicas que se pueden aplicar en función del relieve del terreno, las condiciones ambientales y lo recursos disponibles. Entre las técnicas y practicas que se utilizan están: siembra en contorno o a nivel, barreras vivas, barreas muertas, terrazas individuales, terrazas continuas, cajuelas, acequias, zanjas de infiltración, uso de sombra, coberturas vivas, cobertura muerta, barreras rompe vientos.

La organización considera el manejo de plagas y enfermedades con métodos biológicos, culturales y físicos. Se pueden emplear insecticidas, repelentes y fungicidas botánicos, trampas sexuales, visuales y físicas, los injertos para nematodos, las variedades resistentes a roya, las avispas parasitoides como Cephalonomia estephanoderis para broca y los hongos entomopatogenos, regulación de sombra para ojo de gallo y mal de hilachas; plantas repelentes y plantas para la tuza. Cabe señalar que se pretende contar con cafetales de gran diversidad vegetal para mantener mayor equilibrio ecológico.

Cortar solamente cerezas maduras no dejar frutos maduros en la planta después de la cosecha. 
(continuacion ...)

Descripción del manejo del cultivo de café

Enseguida se presentan los cuadros con la descripción del proceso de manejo del cultivo.

\begin{tabular}{|l|l|}
\hline Beneficiado húmedo. & $\begin{array}{l}\text { Despulpado manual o con uso mínimo de combustible, fermentación natural, sin uso } \\
\text { de aceleradores de síntesis química en cajones de madera o tanques de cemento. }\end{array}$ \\
\hline Lavado. & $\begin{array}{l}\text { Al sol sobre petates o patios de cemento. Pueden utilizarse secadoras de gas o pajilla } \\
\text { se prohíbe el uso de diesel, gasolina y petróleo. }\end{array}$ \\
\hline Secado. & $\begin{array}{l}\text { En lugares separados y libres de contaminantes, sin estar en contacto con el suelo } \\
\text { identificación clara del café para evitar mezclas con café tradicional o convencional. }\end{array}$ \\
\hline Almacenamiento. & $\begin{array}{l}\text { Por separado del producto tradicional o convencional, procesado después de un } \\
\text { limpieza general de los equipos. }\end{array}$ \\
\hline Beneficiado seco. & $\begin{array}{l}\text { Bodegas exclusivas para el café orgánico en caso de almacenar productos orgánicos y } \\
\text { no orgánicos debe haber clara separación e identificación de las áreas, uso de tarimas } \\
\text { costales exclusivos. }\end{array}$ \\
\hline $\begin{array}{l}\text { Procesamiento se almacene y procese el producto orgánico y no orgánico deberá } \\
\text { paralelo. }\end{array}$ & $\begin{array}{l}\text { implementarse una clara separación de las áreas y tiempos de todo el proceso, esto } \\
\text { debe documentarse. }\end{array}$ \\
\hline Industrialización. & $\begin{array}{l}\text { La organización inicio en cooperación con CoPRASSA una línea de producción de } \\
\text { soluble, tostado y molido de café orgánico, el primero con el objetivo de colocarlo en } \\
\text { Estados Unidos a través de la Empresa The original Taste, y el segundo para ventas } \\
\text { locales en la región. }\end{array}$ \\
\hline Control de calidad & $\begin{array}{l}\text { En cuanto a calidad se recibe de los socios solamente producto que cumpla con los } \\
\text { estándares orgánicos como son: } \\
\text { No más de 6\% de mancha. } \\
\text { Humedad promedio de 12\% } \\
\text { Limpio de basuras, piedras, palos y polvo. }\end{array}$ \\
\hline Instalaciones. & $\begin{array}{l}\text { La organización cuenta con oficinas y bodega propia para el mejor desempeño de sus } \\
\text { actividades, y próximamente con un beneficio seco en el cual se beneficiara el café }\end{array}$ \\
\hline
\end{tabular}

\section{MERCADO Y COMERCIALIZACIÓN}

El café producido por Nubes de Oro se destina al mercado de exportación, mediante el uso de certificados orgánicos, de comercio justo y sombra, siendo países como Estados Unidos y Austria los principales destinos del producto, un pequeño porcentaje se destina al mercado nacional. Es importante señalar que Productores Orgánicos Nubes de Oro S. P. R. de R. L. es miembro de RED CARES A.C. La cual se encarga de realizar la certificación de comercio justo, como una estrategia de coordinación y de minimizar los costos de certificación.

De 2013 a 2014 el 80\% de la comercialización del café se realizó de forma directa con compradores como Ellan organic coffes y Eza Austria y el 20\% restante fue comercializado por café y desarrollo S.A. de C. V. Coprassa S.A. Es importante mencionar que para el año 2015 hubo una caída de las ventas de café debido a que la roya daño gran parte de los cultivos, no se alcanzo la calidad en grano para exportación.

\section{PRINCIPALES PROBLEMÁTICAS}

A partir de la caracterización se identificaron algunas debilidades en la asociación, se realizaron dos reuniones con el consejo administrativo y técnico en las instalaciones de la Asociación Nubes de Oro en las cuales expresaron las debilidades que enfrentan. Así mismo se consideraron factores externos que podrían incrementar el riesgo y la vulnerabilidad. 
Figura 2. Diagrama de problemátic as y factores que incrementan el riesgo y la vulnerabilidad

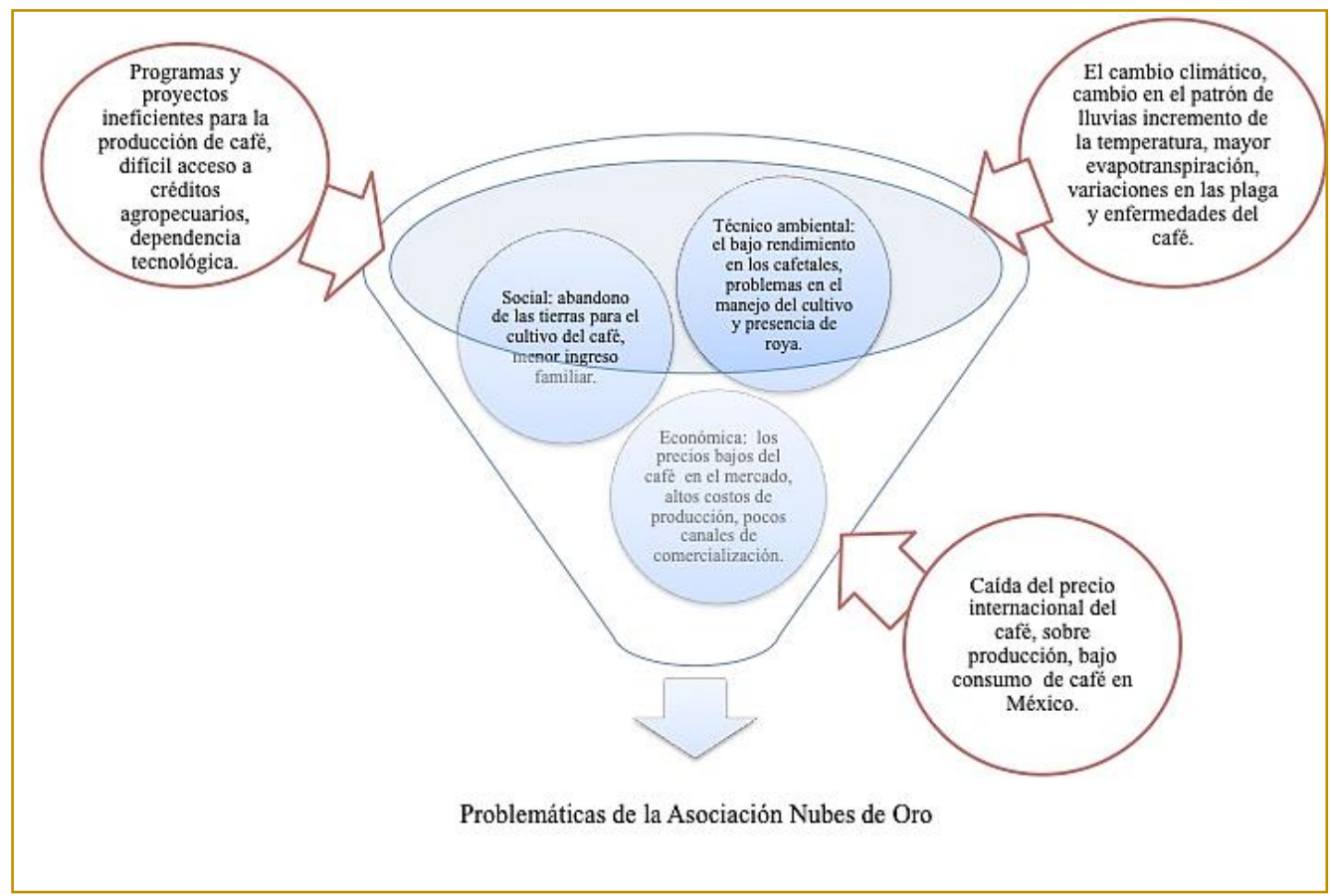

Fuente: elaboración propia.

Las problemáticas se dividieron en tres ámbitos social, técnico-ambiental y económico, se describen a continuación.

- Social: Abandono de las tierras para el cultivo del café, menor ingreso familiar. Factores externos para el ámbito social se identificaron, programas y proyectos deficientes para la producción de café, difícil acceso a créditos agropecuarios, dependencia tecnológica.

- Técnico ambiental: donde se identificó el bajo rendimiento en los cafetales, problemas en el manejo del cultivo y roya. Como factores externos se indicó el cambio climático, cambio en el patrón de lluvias incremento de la temperatura, mayor evapotranspiración y variaciones en las plagas y enfermedades del café.

- Económica: los precios bajos del café en el mercado, altos costos de producción, pocos canales de comercialización. Factores externos económicos se señaló la caída del precio internacional del café, sobre producción, bajo consumo nacional de café en México.

De la misma forma se procedió a realizar un diseño longitudinal de tendencia con la revisión de informes de certificación orgánica de los ciclos de producción desde el 2012 al 2016, los documentos de inspección interna y seguimiento de productores de la asociación, a continuación se mencionan algunas de las problemáticas que se han presentado en los últimos ciclos de producción de café, cabe mencionar que los ciclos de producción tienen una duración 12 meses, estos empiezan a partir del mes de mayo, para esta investigación se tomaron en cuenta cuatro ciclos de producción (Tabla 1).

Tabla 1. Ciclos de producción 2012-2016

\begin{tabular}{|c|c|c|c|c|}
\hline \multirow{2}{*}{ Ciclos } & Productores & $\begin{array}{c}\text { Productores } \\
\text { certificados }\end{array}$ & Mercado & Plagas y enfermedades \\
\hline $2012-2013$ & 220 & 211 & Alta & Daños por Roya (H.vastatrix), \\
\hline $2013-2014$ & 159 & 135 & Baja & Daños por Roya (H.vastatrix) \\
\hline $2014-2015$ & 129 & 112 & Baja & Daños por Roya (H.vastatrix), \\
\hline $2015-2016$ & 366 & 366 & Baja & $\begin{array}{c}\text { Daños causados por la roya del ciclo } \\
\text { anterior }\end{array}$ \\
\hline
\end{tabular}


Se observó que en el ciclo de 2012 a 2013 la organización contaba con 220 miembros en 4 municipios y 20 comunidades de los cuales 211 eran productores orgánicos certificados y 9 se encontraban en transición. Para los ciclos 2013-2014 y 2014-2015 la cantidad de productores disminuyó a esto se atribuyó a que el mercado de café se encontraba a la baja, por tanto los productores no obtuvieron ganancias que esperaban, se piensa que algunos decidieron salir de la asociación para integrase otras asociaciones ó trabajar independientemente, no se tiene un registro para saber el porcentaje de productores que se integraron a otras asociaciones, ni los que decidieron trabajar independientemente.

Así mismo en estos ciclos se presento un brote de roya (Hemileia vastatrix) que afecto la economía de varios productores esto causo que no se realizaran todas las practicas de manejo de cafetales y ocasiono que la producción disminuyera un 60\% (SOTO, 2016). Para 2015-2016 debido la disminución de la producción causadas por roya (H.vastatrix), se percibió un incremento en el número de afiliados a la asociación, pues los productores estaban buscando apoyos técnicos como financieros y una de las alternativas más factible es pertenecer a alguna asociación ya que ellas cuentan con programas de capacitación, apoyos por parte del gobierno y de instituciones no gubernamentales, además a través de las asociaciones se puede obtener la certificaciones y comercializar la producción.

Tabla 2. Productividad de los cafetales 2012-2016

\begin{tabular}{|c|c|c|c|c|c|}
\hline Ciclos & $\begin{array}{l}\text { Superficie } \\
\text { sembrada }\end{array}$ & $\begin{array}{c}\text { Superficie } \\
\text { aprobada } \\
\text { orgánicamente }\end{array}$ & Kg. Cosechados & $\begin{array}{l}\text { Kg. Cosechados } \\
\text { aprobados } \\
\text { orgánicamente }\end{array}$ & Rendimiento \\
\hline $2012-2013$ & 829.1 ha & 776.1 ha & $211833.5 \mathrm{~kg}$ & $194196.5 \mathrm{~kg}$ & $225.5 \mathrm{~kg} / \mathrm{ha}$ \\
\hline 2013-2014 & 680 ha & 557.5 ha & $99,655.1 \mathrm{~kg}$ & $71000.1 \mathrm{~kg}$ & $146.5 \mathrm{~kg} / \mathrm{ha}$ \\
\hline 2014-2015 & 544 ha & 463.0 ha & $228,042.6 \mathrm{~kg}$ & $198,682.6 \mathrm{~kg}$ & $419.9 \mathrm{~kg} / \mathrm{ha}$ \\
\hline $2015-2016$ & 1453 ha & 1453 ha & $654,055 \mathrm{~kg}$ & $654055 \mathrm{~kg}$ & $450 \mathrm{~kg} / \mathrm{ha}$ \\
\hline
\end{tabular}

Para calcular la productividad física de los sistemas de producción se registraron los kilogramos beneficiados de café verde por hectárea $(\mathrm{kg} / \mathrm{ha}$ ) (Tabla 2). En el cuadro se observa que el rendimiento de la producción para el ciclo de 2012-2013 fue de $255.5 \mathrm{~kg}$ por hectárea, una cifra por debajo de el rendimiento promedio de producción en México que de 2000 a 2012, según Flores (2015), fue $382 \mathrm{Kg} / \mathrm{Ha}$ de café verde, para el ciclo 2013-2014 se observó un rendimiento de $138 \mathrm{~kg} /$ ha esto concordó con lo previsto por la Tasa Media de Crecimiento Anual (TMCA) que indico una tendencia negativa en la producción por superficie esto debido a que los cultivos fueron afectados por la presencia de roya (AMECAFE, 2015).

En el ciclo 2014-2015 se observó un mejor rendimiento en los cultivos ya que se obtuvieron $419.9 \mathrm{~kg}$ por hectárea un 10\% más que el rendimiento promedio, para 2015 también se incremento el rendimiento a $450 \mathrm{~kg}$ por hectárea esto pudo deberse a los resultados de las estrategias de renovación de cultivos que se implementaron en 2011, fomentados por el gobierno a través de las asociaciones de cafeticultores, pues los cafetos comienzan a ser productivos dependiendo de la variedad a partir del 3 o 4 año después de la plantación.

Las problemáticas identificadas en el diseño longitudinal de tendencia de los informes de certificación orgánica de los ciclos de producción desde 2012-2016 son; baja productividad, cafetos envejecidos, escasa práctica de poda, reducción de sombra y diversidad, cambio climático, variedades susceptibles a roya, no existe una entidad que regule los viveros asimismo se están usando distintas variedades de café sin que se conozca su origen (SOTO, 2016). Algunos retos de las asociaciones de pequeños productores ante estas problematicas son fortalecer los programas de capacitación con la ayuda de ONGs y programas gubernamentales, buscar incrementar la calidad para mejorar el precio, examinar perspectivas en los mercados alternativos, el café como producto principal y productos alternos al café cultivados en sistemas bajo sombra, examinar tecnologías para el incremento de la productividad por medio de nuevas variedades pero siempre por la vía sustentable. 


\section{CONCLUSIÓN}

La Cafeticultura Orgánica a pesar de sus grandes virtudes a favor del ambiente y contribución en el desarrollo social y la economía de pequeños productores, presenta serios problemas, esto nos lleva a pesar que debe renovarse sustancialmente, articulando acciones políticas integradas y afines de resguardar a los cafeticultores, impulsando la de promoción para incrementar el consumo interno de café mexicano, desarrollar estudios que alcancen a los productores y de esta forma puedan disponer de información importante sobre mercado, tecnologías, innovaciones y oportunidades de negocios, además se debe analizar papel de las organizaciones y su función en el desarrollo comunitario integral.

\section{AGRADECIMIENTOS}

Universidad autónoma del estado de méxico, Facultad de Química programa de Posgrado en Ciencias Ambientales, al Conacyt, a la Asociación Nubes de Oro, por su valiosa colaboración y aportación para este trabajo.

\section{REFERÊNCIAS}

[1] Amecafe. Taller de prevención para el combate de la roya y revisión de programas, México D.F, Enero de 2015.

[2] Méndez, V.E.; Bacon, C.M.; Olson, M.B.; Morris, K.S.; Shattuck, A. Conservación de agrobiodiversidad y medios de vida en cooperativas de café bajo sombra en Centroamérica. Revista Ecosistemas 22(1): 16-24,2013.

[3] Mestries, F. Crisis cafetalera y migración internacional en Veracruz. En: El Colegio de la Frontera Norte. Migraciones Internacionales 2 (2), julio-diciembre, El Colegio de la Frontera Norte, México. Programa Mitchell, 2003.

[4] Villafuerte, D. Y García M. Del C. Veinte años de neoliberalismo en el campo chiapaneco. En Anuario 2006, Cesmeca-Unicach, Tuxtla Gutiérrez, Chiapas, 2007.

[5] Soto P. L. Contexto del sector cafetalero en México, I Foro de Roya y cambio Climatico, San Cristóbal de las Casas, Chiapas, México, 2016. 


\section{Baṕtulo 10}

\section{EMERGÊNCIA DE PLÂNTULAS DE VARIEDADES CRIOULAS DE ALFACE EM SUBSTRATO ALTERNATIVO}

\section{Francisco Braz Daleprane;}

João Nacir Colombo

Mariana Zandomênico Mangeiro

Resumo: 0 uso de sementes crioulas é importante na agricultura familiar, pois são materiais que não sofreram melhoramento genético, usada por comunidades tradicionais. $\mathrm{Na}$ produção de mudas em sistemas agroecológicos é comum os agricultores criarem seu próprio substrato, devido ao alto custo de substratos comerciais. Objetivou-se avaliar quatro variedades de alface crioula em um substrato alternativo, composto por terra de barranco, esterco bovino e samambaia do campo (Pteridium aquilinum) triturada (2:1:1). 0 experimento foi conduzido no viveiro do IFES - campus Santa Teresa, delineamento experimental em DIC com 4 tratamentos e 6 repetições, cada um com uma variedade crioula: Rabo de peixe (T1), Verde clara lisa (T2), Alagoano 1 (T3) e Alagoano 2 (T4). Foram avaliados o Índice de Velocidade de Emergência (IVE), a Porcentagem de Emergência de Plântulas (PEP) e o Tempo Médio de Emergência (TME). As variedades Alagoano 2 e Verde clara lisa foram as que mais se destacaram em todas as varáveis avaliadas.

Palavras- chave: Sementes crioulas; Lactuca sativa L.; sistemas agroecológicos. 


\section{INTRODUCC̃̃O}

A alface (Lactuca sativa L.) é a hortaliça folhosa mais consumida e cultivada em todo Brasil, sendo fonte de vitaminas e sais minerais, com destaque no elevado teor de vitamina A (Fernandes et al., 2002; Marques et al., 2003). Sua larga adaptação às condições climáticas diversas, a possibilidade de cultivos sucessivos no mesmo ano, o baixo custo de produção, a pouca suscetibilidade a pragas e doenças e a comercialização segura, fazem com que seja a hortaliça preferida pelos pequenos agricultores, o que lhe confere grande importância econômica e social, sendo significativo fator de agregação do homem do campo (Medeiros et al.,2007).

A propagação é realizada via sexuada e geralmente utiliza-se o transplantio, sendo necessária a produção de mudas. 0 sistema de produção de mudas em bandejas de isopor começou a ser empregado a partir de 1984 no Brasil (Minami, 1995). Atualmente para a produção de mudas de hortaliças, o uso de bandejas multicelulares de poliestireno expandido e posterior transplante para os canteiros é a forma mais utilizada, obtendo-se assim plantas mais vigorosas e produtivas (Marques et al., 2003), devido ao maior cuidado na fase de germinação e emergência, além de outras vantagens como a economia de substratos e de espaço dentro do viveiro, alto índice de pegamento após o transplante, minimização de tratamentos fitossanitários e baixos danos às raízes no momento do transplantio (Oliveira; Scivittaro; Vasconcellos, 1993).

0 uso de sementes crioulas no cultivo, principalmente da agricultura familiar, é importante, pois são materiais que não sofreram melhoramento genético, e são chamadas de crioulas, pois são manejadas por comunidades tradicionais que já possuem as sementes há varias gerações, conhecendo a sua origem. Quando ocorre a perda desse material genético os produtores são obrigados a comprar sementes convencionais, tornando-se dependentes da compra do pacote tecnológico que envolve a venda casada de sementes e insumos agrícolas.

A produção de mudas a partir de sementes crioulas, tornam o produtor independente do pacote tecnológico presente nos sistemas convencionais de cultivo, pois podem produzir mudas a partir de sementes originadas da sua propriedade, proporcionando ao consumidor condições de conhecer a procedência de seu produto.

Na produção de mudas em sistemas agroecológicos é comum os agricultores criarem seu próprio substrato a partir da mistura de diversos materiais, devido ao alto custo de substratos comerciais. Geralmente, os substratos são compostos por misturas de diferentes materiais, pois dificilmente um único material apresentará todas as características adequadas para compor um bom substrato (Gomes e Silva, 2004).

Para a composição de substratos, costuma-se adicionar fontes de matéria orgânica, fornecendo nutrientes, e materiais com a função de aerar o substrato, sendo esse um fator importante para o crescimento das raízes. Na maioria das vezes os materiais necessários para a formação de um bom substrato são facilmente encontrados nas propriedades, facilitando assim o uso pelos agricultores, tornando-se independentes do uso de substratos comerciais.

O substrato ideal deve garantir a manutenção mecânica do sistema radicular da planta, deve ser capaz de manter bom suprimento de água e nutrientes, e permitir as trocas gasosas entre as raízes e o meio externo (Minami e Puchala, 2000).

Este trabalho objetivou avaliar o poder germinativo (emergência de plântulas) de quatro variedades de alface crioula em um substrato alternativo.

\section{MATERIAL E MÉTODOS}

0 experimento foi conduzido no IFES - campus Santa Teresa (latitude 19o 48' 21"S, longitude 40 $40^{\prime}$ 44”W) e altitude de 174 metros. Foi realizado no Viveiro de Produção de Mudas de Hortaliças do campus.

0 delineamento experimental utilizado foi o de blocos inteiramente casualizados com 4 tratamentos e 6 repetições . Cada tratamento foi representado por uma variedade crioula obtida de produtores da Região norte do estado do Espírito Santo, sendo assim distribuídos: Tratamento 01 :Rabo de Peixe; tratamento 02: Verde Clara Lisa; tratamento 03: Alagoano 1 e tratamento 04: Alagoano 2. As mudas foram produzidas em bandejas de isopor de 200 células, preenchidas com o substrato obtido a partir da mistura de terra de barranco, esterco bovino e samambaia do campo (Pteridium aquilinum) triturada, na proporção de 2:1:1. Foram utilizadas cinco sementes por célula. 
Após a semeadura foi avaliado o Índice de Velocidade de Emergência (IVE), a Porcentagem de Emergência de Plântulas (PEP) e o Tempo Médio de Emergência (TME). Para determinação do Índice de Velocidade de Emergência (IVE) foi feita a contagem diária do número de plantas emergidas até estabilizarem (adaptado de Maguire, 1962):

$$
I V E=\frac{E_{1}}{N_{1}}+\frac{E_{2}}{N_{2}}+\cdots+\frac{E_{n}}{N_{n}} ; \text { em que: }
$$

IVE = índice de velocidade de emergência;

$E_{1}, E_{2}, E_{n}=$ número de plântulas emergidas na primeira, segunda, ..., última contagem e;

$\mathrm{N}_{1}, \mathrm{~N}_{2}, \mathrm{~N}_{\mathrm{n}}=$ número de dias da semeadura à primeira, segunda, ..., última contagem.

Na última contagem das plântulas emergidas foi determinada a porcentagem de emergência em cada tratamento por meio da equação:

$$
P E P=\frac{N p}{N s} \times 100 ; \text { em que: }
$$

PEP = porcentagem de emergência de plântulas (\%);

$\mathrm{N}_{\mathrm{p}}$ = número de plantas emergidas e;

$\mathrm{N}_{\mathrm{s}}=$ número de sementes distribuídas no plantio.

Os dados obtidos foram submetidos à análise de variância, e as médias comparadas pelo teste de Tukey $(\mathrm{p}=0,05)$.

\section{RESULTADOS E DISCUSSÃO}

Na tabela 1 são apresentados os valores de porcentagem de emergência de plântulas, o índice de velocidade de emergência e o tempo médio de emergência de cada uma das variáveis avaliadas.

Tabela 1- Porcentagem de emergência de plântulas (PEP), Índice de velocidade de emergência (IVE) e

\begin{tabular}{|c|c|c|c|}
\hline Variedade & PEP (\%) & IVE & TME (dias) \\
\hline Rabo de Peixe & $34,87 \mathrm{~b}$ & $14,79 \mathrm{~b}$ & 6,29a \\
\hline Verde Clara Lisa & $43,73 a b$ & $22,22 a$ & $5,32 b$ \\
\hline Alagoano 1 & $31,93 b$ & $13,49 b$ & $6,21 a$ \\
\hline Alagoano 2 & $53,20^{\mathrm{a}}$ & $26,26 a$ & $5,40 \mathrm{~b}$ \\
\hline Valor de $\mathbf{P}$ & $<0,0001$ & 0,0075 & $<0,0001$ \\
\hline
\end{tabular}
tempo médio de emergência (TME) de diferentes variedades crioulas de alface.

A variedade Alagoano 2 apresentou maiores valores de porcentagem de emergência de plântulas quando comparado com a Rabo de Peixe, e valores semelhantes aos da Verde Clara Lisa, que não diferenciou das demais. Quando avaliado o índice de emergência, as variedades Alagoano 2 e Verde Clara Lisa foram as que apresentaram os melhores resultados, enquanto para o tempo médio de emergência, maiores valores foram observados para Alagoano 1 e Rabo de Peixe.

As variedades Alagoano 2 e Verde Clara Lisa foram as que mais se destacaram em todas as varáveis avaliadas, pois além de apresentarem alto percentual de emergência e velocidade, foram as que apresentaram menor tempo médio de emergência, característica importante na fase de formação de mudas.

Um dos fatores que podem ter influenciado a baixa emergência de sementes das variedades Rabo de Peixe e Verde Clara Lisa, foi a proporção de terra utilizada, misturou-se duas partes de terra, uma de esterco 
bovino e uma de samambaia triturada, com a proporção de terra utilizada a semente pode ter apresentado alguma dificuldade para emergir devido a compactação do solo causada pela terra. E também as sementes crioulas não passaram por nenhum tratamento pré-germinativo.

A média de temperatura máxima no período do experimento foi de $31,8^{\circ} \mathrm{C}$, chegando a temperaturas de até $34,6^{\circ} \mathrm{C}$, o que pode ter influenciado negativamente na germinação das plântulas de alface. Segundo Nascimento e Pereira (2007), a temperatura ótima para germinação de alface situa-se em torno de $20^{\circ} \mathrm{C}$, e a maioria das cultivares não germina em temperaturas superiores a $30^{\circ} \mathrm{C}$, sendo a temperatura um grande influenciador neste processo para a espécie.

Outro fator de relevância na germinação é a profundidade de semeadura, segundo Marcos Filho (2005) em sementes sensíveis à luz, como as de alface, esta profundidade deve ser inferior a $1 \mathrm{~cm}$, pois radiações vermelhas $(660 \mathrm{~nm})$ penetram até $2,5 \mathrm{~cm}$, enquanto as infravermelhas $(730 \mathrm{~nm})$ atingem maior profundidade no solo, permitindo uma maior exposição da semente apenas a radiações prejudiciais a germinação; além de que estas sementes a maiores profundidades podem não ter energia suficiente para ultrapassar a camada do solo.

Com isso as variedades testadas não apresentaram resultados satisfatórios de emergência, sendo necessário testa-las em outros substratos, para que as mesmas possam apresentar melhores índices de emergência de plântulas.

\section{CONCLUSÃO}

De acordo com o experimento as variedades que apresentaram melhores índices germinativos (porcentagem de emergência, índice de velocidade de emergência e tempo médio de emergência) no substrato utilizado, foram a Verde Clara Lisa e a Alagoano 2.

\section{REFERÊNCIAS}

[1] Fernandes, A. A.; Martinez, H. E. P.; Pereira, P. R. G.; Fonseca, M. C. M. Produtividade, acúmulo de nitrato e estado nutricional de cultivares de alface, em hidroponia, em função de fontes de nutrientes. Horticultura Brasileira, Brasília, v. 20, n. 2, p. 195-200, jun. 2002.

[2] Gomes, J. M.; Silva, A. R. Os substratos e sua influência na qualidade de mudas. In: Barbosa, J. G.; Martinez, H. E. P.; Pedrosa, M. W.; Sediyama, M. A. N. Nutrição e adubação de plantas cultivadas em substratos. Viçosa: UFV, 2004, p. 190-225.

[3] Marcos Filho, J. Fisiologia de sementes de plantas cultivadas. Piracicaba: Fealq, 2005. 495 p.

[4] Marques, P. A. A.; Baldotto, P. V.; Santos, A. C. P.; Oliveira, L. Qualidade de mudas de alface formadas em bandejas de isopor com diferentes números de células. Horticultura Brasileira, Brasília, v. 21, n. 4, p. 649-651, out./dez. 2003.

[5] Medeiros DC; Lima BAB; Barbosa MR; ANJOS RSB; BORGES RD; Cavalcante Neto JG; Marques LF. 2007. Produção de mudas de alface com biofertilizantes e substratos. Horticultura Brasileira 25: 433-436.

[6] Minami, K. Produção de mudas de alta qualidade em horticultura. São Paulo: T.A. Queiroz, 1995.

[7] Minami, K; Puchala, B. Produção de mudas de hortaliças de alta qualidade. Horticultura Brasileira, Brasília, v. 18, suplemento, p. 162-163, 2000.

[8] Nascimento, W. M.; Pereira, R. S. Testes para avaliação do potencial fisiológico de sementes de alface e sua relação com a germinação sob temperaturas adversas. Revista Brasileira de Sementes, Londrina, v. 29, n. 3, p. 175-179, 2007.

[9] Oliveira, R. P.; Scivittaro, W. B.; Vasconcellos, L. A. B. C. Avaliação de mudas de maracujazeiro em função do substrato e do tipo de bandeja. Scientia Agricola, Piracicaba, v. 50, n. 2, p. 261-266, 1993. 


\section{Baṕítulo 11}

CARACTERIZAÇÃO E IMPORTÂNCIA DAS ESPÉCIES VEGETAIS PRODUZIDAS NA COMUNIDADE SANTA ROSA, CAPANEMA/PA, COM ÊNFASE NA AGROECOLOGIA

\section{Karoline Roberta da Silva Costa \\ Luan Daniel Silva Ferreira \\ Antonio Carlos Monteiro Filho \\ Diocléa Almeida Seabra Silva \\ Williams Jorge da Cruz Macêdo \\ Salma Saráty de Carvalho}

Resumo: Objetivou no presente trabalho caracterizar as espécies vegetais, correlacionando com sua importância para a comunidade, além de dar ênfase em saberes agroecológicos praticados na comunidade. 0 trabalho de campo ocorreu no dia 10/08/2018 na comunidade de Santa Rosa, Capanema - PA. Foram utilizados questionários semiestruturados, com perguntas sobre o socioeconômico e ambiental. A identificação das espécies presente na flora da região, foram feitas por meio de análises visuais e de material fotográfico, com isso, foram realizadas pesquisas em banco de dados. Foram identificadas 38 espécies vegetais (35 gêneros e 29 famílias) totalizando 90 indivíduos. Sendo as famílias que mais contribuíram para a riqueza de espécies, Arecaceae, Rutaceae e Anacardiaceae. As famílias Arecaceae e Rutáceae apresentaram maior importância sociológica, compondo $23,4 \%$ das espécies. Foi possível montar sugestões a serem tomadas pelos moradores da comunidade para diminuir práticas consideradas com potencial para degradação do meio ambiente.

Palavras-chave: Identificação, Socioeconômico, Meio ambiente. 


\section{INTRODUÇÃO}

O uso dos recursos vegetais está fortemente presente na cultura popular que é transmitida de pais para filhos. Este conhecimento é encontrado junto a populações tradicionais e contemporâneas, e pelo que se tem observado, tende à redução ou mesmo ao desaparecimento, quando sofre a ação inexorável da modernidade (NETO et al., 2010).

No Brasil, há uma considerável quantidade de estudos florísticos em quintais, a maioria apresentando dados qualitativos com descrições da estrutura, composição, organização e manutenção dessas práticas (ANDERSON et al., 1985). Nos últimos anos, o sistema de produção da agricultura convencional vem perdendo cada vez importância, cedendo espaço para os chamados sistemas alternativos de produção de base agroecológica. Fruto de um processo de conscientização ecológica, a sociedade vem preferindo mais os produtos oriundos dos sistemas alternativos de produção de base agroecológica, em detrimentos aos produtos da agricultura convencional.

Para Santos (2001) a agricultura familiar ainda é a forma preponderante de produção agrícola em várias áreas do país, e também é condição fundamental para que haja uma sobrevida para a economia da grande maioria dos municípios brasileiros.

A agroecologia tem como princípio básico o uso racional dos recursos naturais e surge como mecanismo de transformação da situação atual da agricultura, preocupando-se não apenas com a cadeia produtiva e a renda, mas com a relação ser humano-ambiente, buscando modelos sustentáveis para o campo (GLIESSMAN, 2001; ALTIERI, 2002; CAPORAL et al, 2009).

Diante do exposto espera-se mensurar de forma qualitativa e quantitativa as espécies vegetais presentes na comunidade, e que possuem algum valor socioeconômico, além de enfatizar aspectos agroecológicos praticados pelos moradores.

\section{METODOLOGIA}

A comunidade Santa Rosa está ligada política e geograficamente ao município de Capanema-PA, situado no Nordeste Paraense, a $142 \mathrm{~km}$ da capital. Localizada a $20 \mathrm{~km}$ de distância do centro da cidade (Figura 1). A comunidade possui em torno de 150 famílias, onde a maioria depende da agricultara familiar e de subsistência. 0 clima estações. A temperatura média anual é de 26,5ํㅡ e máxima de 31,5ํㅡ (CUNHA, 2011).

Figura 1. Mapa da comunidade de Santa Rosa Capanema-Pa.

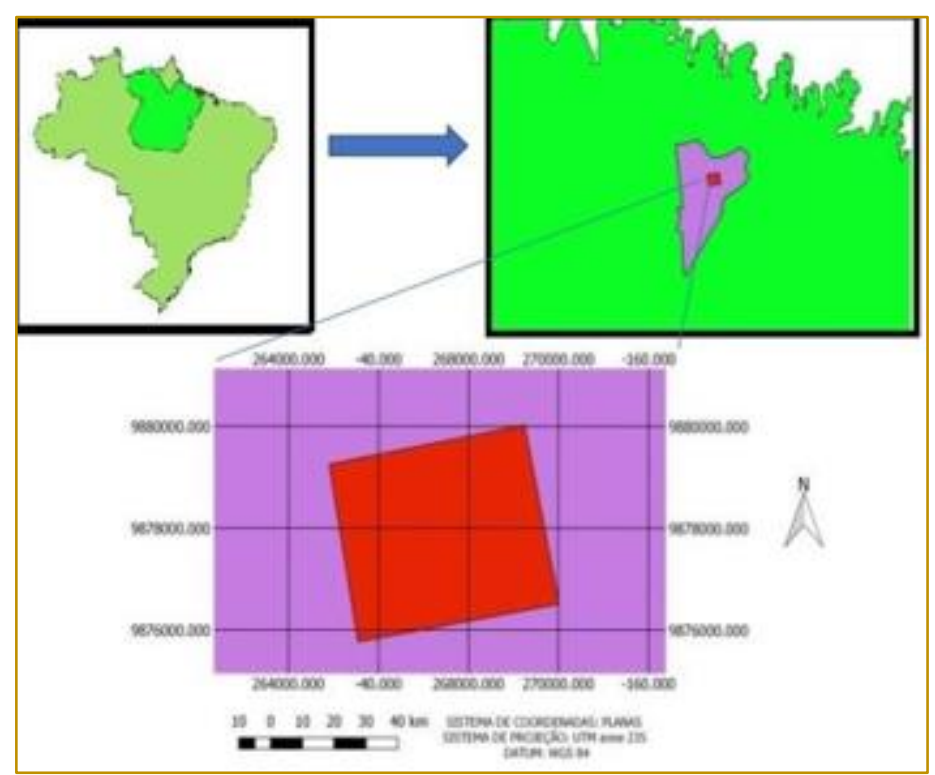


O trabalho de campo ocorreu no dia 10 de agosto de 2018, na comunidade Santa Rosa, Capanema-PA. Para a obtenção dos dados foram utilizados questionários semiestruturados, que foram aplicados a dez pessoas residentes na comunidade, com aprovação dos entrevistados, juntamente com a assinatura de termos de consentimentos por cada morador.

Os questionários foram aplicados nas residências dos entrevistados, sendo que em cada residência visitada apenas uma pessoa era selecionada para participar da pesquisa. 0 questionário socioeconômico e ambiental foi composto por 14 perguntas, sendo seis delas voltadas para a caracterização do perfil socioeconômico dos entrevistados e oito referentes as áreas de cultivo, para saber quais espécies de vegetais existiam, de que forma elas são utilizadas, quais são as práticas mais utilizadas com ênfase na agroecologia e práticas de manejo e conservação do solo, além da sua importância para a comunidade.

Através do material coletado durante os levantamentos florísticos (amostragem no local, com retirada de material fotográfico), foi elaborada uma listagem contendo as famílias, gêneros e espécies, bem como riqueza de espécies. Além de classificar as espécies, também houve a classificação segundo seu modo de vida (habitat), sendo arbustiva ou arbórea e sua área de incidência natural.

E por fim, foi montando uma tabela, elaborado a partir das respostas dos questionários, pontuando as práticas usadas para melhoria da fertilidade do solo, que são comumente feitas pelos residentes, e relacionando-as com o conceito eminente de agroecologia, além de uma sugestão para melhorar tais práticas e focalizando de forma clara e concisa, os princípios da agroecologia, adaptando-os para a comunidade, no seu âmbito sociocultural e econômico.

\section{RESULTADOS E DISCUSSÕES}

0 total de indivíduos identificados foram 38 espécies vegetais, distribuídas em 35 gêneros, 29 famílias, totalizando 90 indivíduos (Tabela 1).

Tabela 1. Distribuição das espécies vegetais da comunidade Santa Rosa, Capanema - PA.

\begin{tabular}{|c|c|c|c|c|c|}
\hline $\begin{array}{l}\text { № de } \\
\text { Indivíduos }\end{array}$ & Espécies & $\begin{array}{l}\text { Voucher do } \\
\text { Herbário }\end{array}$ & Família & Hábito & Área de incidência \\
\hline 6 & Coqueiro (Cocos nucifera) & $\operatorname{Cocos}$ & Arecaceae & Arbóreo & Região tropical \\
\hline 6 & $\begin{array}{c}\text { Laranjeira (Citrus } \\
\text { sinensis) }\end{array}$ & Citrus & Rutaceas & Arbóreo & Cosmopolita \\
\hline 6 & $\begin{array}{c}\text { Cajueiro (Anarcadium } \\
\text { occidentale }\end{array}$ & Anacardium & Anacardiaceae & Arbóreo & Nordeste do Brasil \\
\hline 6 & $\begin{array}{c}\text { Açaizeiro (Euterpe } \\
\text { oleracea) }\end{array}$ & Euterpe & Arecaceae & Arbóreo & Várzea (Amazônia) \\
\hline 4 & $\begin{array}{l}\text { Jaqueira (Artocarpus } \\
\text { heterophillus) }\end{array}$ & Artocarpus & Moraceae & Arbóreo & Região tropical \\
\hline 4 & Limoeiro (Citrus limon) & Citrus & Rutaceae & Arbóreo & Quente e temperado \\
\hline 4 & $\begin{array}{c}\text { Mangueira (Mangifera } \\
\text { indica) }\end{array}$ & Mangifera & Anacardiaceae & Arbóreo & Cosmopolita \\
\hline 3 & $\begin{array}{c}\text { Goiabeira (Psidium } \\
\text { guajava) }\end{array}$ & Psidium & Myrtaceae & Arbóreo & Nativa da América \\
\hline 2 & $\begin{array}{c}\text { Pupunheira (Bactris } \\
\text { gasipaes) }\end{array}$ & Bactris & Arecaceae & Arbóreo & Região Amazônica \\
\hline 2 & $\begin{array}{c}\text { Cacaueiro (Theobroma } \\
\text { cacao) }\end{array}$ & Theobroma & Malvaceae & Arbóreo & Região Amazônica \\
\hline 2 & $\begin{array}{c}\text { Aceroleira (Malpighia } \\
\text { glabra) }\end{array}$ & Malpighia & Malpighiáceas & Arbustivo & América do Sul e Central \\
\hline 2 & $\begin{array}{c}\text { Pimenta do reino (Piper } \\
\text { nigrum) }\end{array}$ & Piper & Piperaceae, & Arbustivo & Quente e úmido \\
\hline 2 & $\begin{array}{c}\text { Maracujazeiro (Passiflora } \\
\text { edulis) }\end{array}$ & Passiflora & Passifloraceae & Arbustivo & Região tropical \\
\hline 2 & $\begin{array}{c}\text { Cupuaçuzeiro (Theobroma } \\
\text { grandiflorum) }\end{array}$ & Theobroma L. & Malvaceae & Arbóreo & Região Amazônica \\
\hline 2 & Bananeira (Musa spp.) & Musa & Musaceae & Arbustivo & Região tropical \\
\hline
\end{tabular}


(continuação ...)

Tabela 1. Distribuição das espécies vegetais da comunidade Santa Rosa, Capanema - PA.

\begin{tabular}{|c|c|c|c|c|c|}
\hline № de Indivíduos & Espécies & $\begin{array}{l}\text { Voucher do } \\
\text { Herbário }\end{array}$ & Família & Hábito & Área de incidência \\
\hline 2 & $\begin{array}{c}\text { Mamoeiro (Carica } \\
\text { papaya) }\end{array}$ & Carica & Caricaceae & Arbustivo & Região tropical \\
\hline 2 & Urucu (Bixa orellana) & Bixa & Bixaceae & Arbóreo & América tropical \\
\hline 2 & Arroz (Oryza sativa) & Oryza & Poaceae & Herbáceo & Ásia, África e América \\
\hline 2 & Ingázeiro (Inga edulis) & Inga & Fabaceae & Arbóreo & Região neotropical \\
\hline 2 & $\begin{array}{c}\text { Cheiro verde } \\
\text { (Petroselinum crispum) }\end{array}$ & Petroselinum & Apiaceae & Herbáceo & $\begin{array}{c}\text { Mediterrâneo, Europa e } \\
\text { América }\end{array}$ \\
\hline 2 & $\begin{array}{c}\text { Couve galega (Brassica } \\
\text { oleracea) }\end{array}$ & Brassica & Brassicaceae & Herbáceo & Portugal e Brasil \\
\hline 2 & $\begin{array}{c}\text { Cariru (Talinum } \\
\text { triangulare) }\end{array}$ & Talinum & Talinaceae & Herbáceo & América e África central \\
\hline 2 & $\begin{array}{l}\text { Bacurizeiro (Platonia } \\
\text { insignis) }\end{array}$ & Platonia & Clusiaceae & Arbóreo & América do Sul \\
\hline 2 & $\begin{array}{c}\text { Cafezeiro (Coffea } \\
\text { arabica) }\end{array}$ & Coffea & Rubiaceae & Arbustivo & Região tropical \\
\hline 2 & $\begin{array}{c}\text { Abacateiro (Persea } \\
\text { americana) }\end{array}$ & Persea & Lauraceae & Arbóreo & $\begin{array}{l}\text { Região tropical e } \\
\text { Subtropical }\end{array}$ \\
\hline 2 & $\begin{array}{c}\text { Castanheira } \\
\text { (Bertholletia excelsa) }\end{array}$ & Bertholletia & Lecythidacea & Arbóreo & Região Amazônica \\
\hline 2 & $\begin{array}{l}\text { Hortelã (Mentha } \\
\text { spicata) }\end{array}$ & Mentha & Lamiaceae & Herbáceo & Cosmopolita \\
\hline 2 & $\begin{array}{c}\text { Arruda (Ruta } \\
\text { graveolens) }\end{array}$ & Ruta & Rutaceae & Subarbustivo & Cosmopolita \\
\hline 2 & $\begin{array}{c}\text { Elixir paregórico (Piper } \\
\text { callosum) }\end{array}$ & Piper & Piperaceae & Arbustivo & Região Amazônica \\
\hline 1 & Pião (Jatropha curcas) & Jatropha & Euphorbiaceae & Arbustivo & $\begin{array}{l}\text { Caatinga e Região } \\
\text { Amazônica }\end{array}$ \\
\hline 1 & Babosa (Aloe vera) & Aloe & $\begin{array}{c}\text { Xanthorrhoeac } \\
\text { eae }\end{array}$ & Arbustivo & Região tropical \\
\hline 1 & $\begin{array}{c}\text { Chambá (Justicia } \\
\text { pectoralis) }\end{array}$ & Justicia & Acanthaceae & Herbáceo & América Latina \\
\hline 1 & $\begin{array}{c}\text { Verônica (Veronica } \\
\text { spicata) }\end{array}$ & Veronica & Plantaginaceae & Arbustivo & América do Sul \\
\hline 1 & $\begin{array}{l}\text { Barbatimão } \\
\text { (Stryphnodendron } \\
\text { adstringens) }\end{array}$ & Stryphnodendron & Fabaceae & Arbóreo & Brasil \\
\hline 1 & Pião (Jatropha curcas) & Jatropha & Euphorbiaceae & Arbustivo & $\begin{array}{l}\text { Caatinga e Região } \\
\text { Amazônica }\end{array}$ \\
\hline 1 & Jucá (Libidibia ferrea) & Libidibia & Fabaceae & Arbóreo & Brasil \\
\hline 1 & $\begin{array}{l}\text { Boldo (Peumus } \\
\text { boldus) }\end{array}$ & Peumus & Monimiaceae & Arbustivo & América do Sul \\
\hline 1 & $\begin{array}{l}\text { Pluma (Celosia } \\
\text { argentea) }\end{array}$ & Celosia & Amaranthaceae & Herbáceo & Região tropical \\
\hline 1 & $\begin{array}{l}\text { Cacto (Stapelia } \\
\text { hirsuta) }\end{array}$ & Stapelia & Apocynaceae & Arbustivo & América do Norte \\
\hline
\end{tabular}

Quanto ao hábito de crescimento das espécies amostradas, 12 (31,57\%) foram arbustivas, 18 (47,36\%) arbóreas, sete $(18,42 \%)$ herbáceas. As famílias que mais contribuíram para a riqueza de espécies foram: Arecaceae (14 espécies), Rutaceae (12 espécies) e Anacardiaceae (dez espécies). Os gêneros com maior riqueza de espécies foram Citrus (dez espécies) seguidos por Cocos (seis espécies), Anacardium (seis espécies) e Euterpe (seis espécies). Quanto à frequência quatro espécies apresentaram os valores mais altos, indicando que as mesmas foram registradas em boa parte das parcelas (20 a 50\%) (Figura 2). 
Figura 2. Espécies de plantas mais citadas.

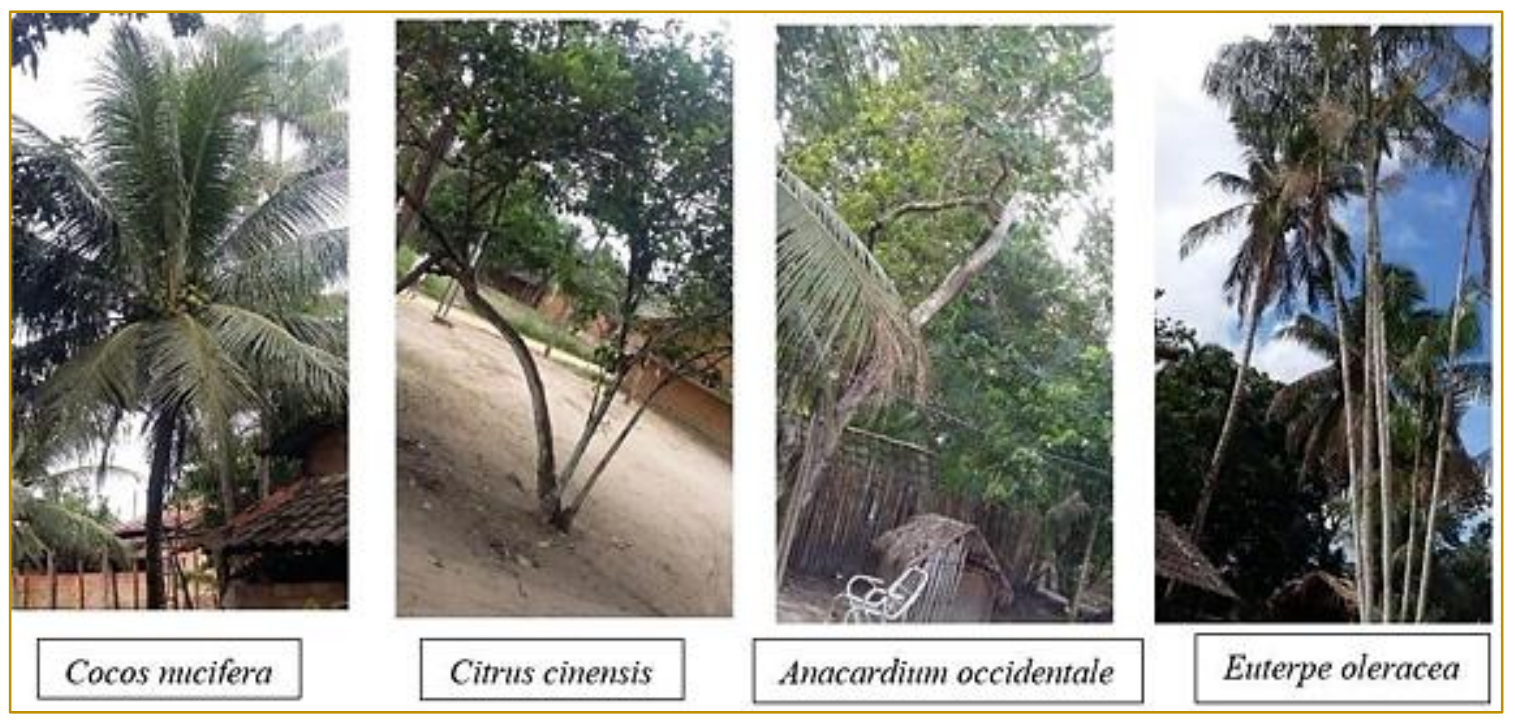

O levantamento florístico apresentou representativa riqueza das espécies arbustivo- arbóreas na área estudada (30 espécies). A maioria das espécies encontradas neste estudo caracteriza a vegetação de região amazônica. Entretanto, os resultados obtidos no levantamento florístico demonstram expressiva riqueza de espécies e de gêneros (Figura 3).

Figura 3. Riqueza de espécies em relação às famílias presentes vegetação da comunidade.

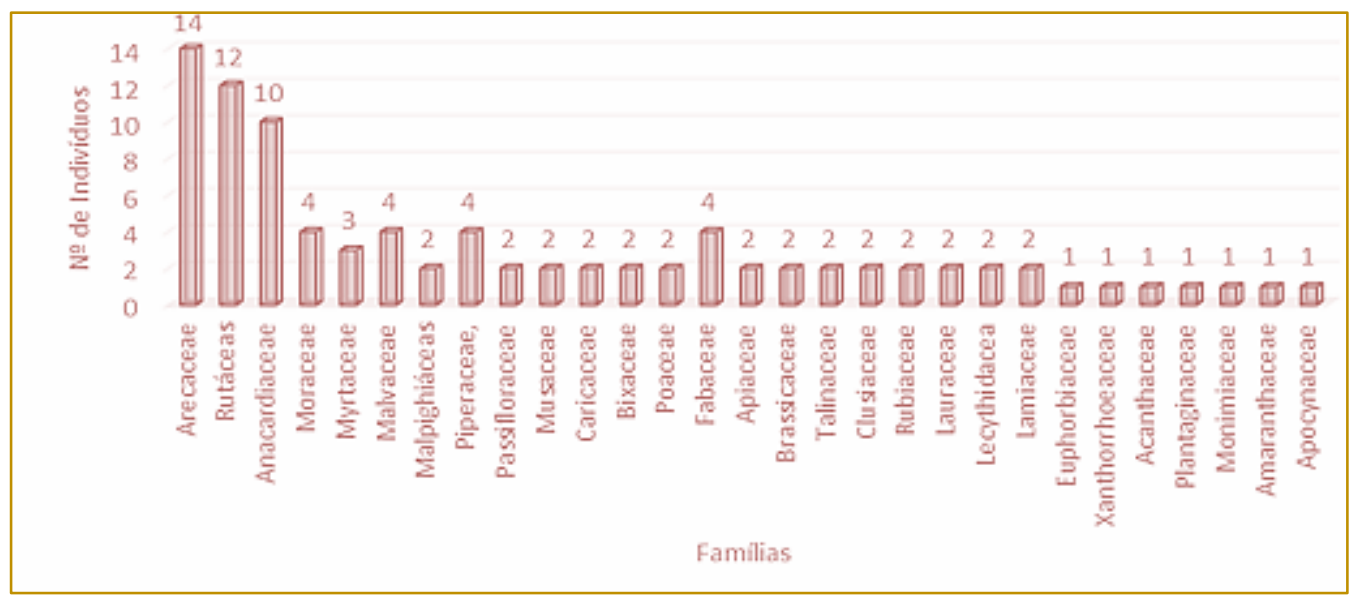

As espécies vegetais foram classificadas levando em consideração sua utilidade para fins de alimentação, medicinal ou ornamentação. A utilização de espécies vegetais é uma prática bastante disseminada. Marques (1995) aponta que as conexões com os componentes botânicos têm sido múltiplas, quer seja quanto ao número de espécies envolvidas, quer seja quanto às finalidades interativas. As formas de uso mais frequentes foram alimentar com 26 espécies, 11 medicinais e uma para ornamentação (Tabela 2). 
Tabela 2. Formas de uso da vegetação das áreas estudadas.

\begin{tabular}{|c|c|c|}
\hline Espécies & Família & Utilidade \\
\hline Coqueiro (Cocos nucifera) & Arecaceae & Alimentação \\
\hline Laranjeira (Citrus sinensis) & Rutáceas & Alimentação \\
\hline Cajueiro (Anarcadium occidentale & Anacardiaceae & Alimentação \\
\hline Açaizeiro (Euterpe oleracea) & Arecaceae & Alimentação \\
\hline Jaqueira (Artocarpus heterophillus) & Moraceae & Alimentação \\
\hline Limoeiro (Citrus limon) & Rutaceae & Alimentação \\
\hline Mangueira (Mangifera indica) & Anacardiaceae & Alimentação \\
\hline Goiabeira (Psidium guajava) & Myrtaceae & Alimentação \\
\hline Pupunheira (Bactris gasipaes) & Arecaceae & Alimentação \\
\hline Cacaueiro (Theobroma cacao) & Malvaceae & Alimentação \\
\hline Aceroleira (Malpighia glabra) & Malpighiáceas & Alimentação \\
\hline Pimenta do reino (Piper nigrum) & Piperaceae, & Alimentação \\
\hline Maracujazeiro (Passiflora edulis) & Passifloraceae & Alimentação \\
\hline Cupuaçuzeiro (Theobroma grandiflorum) & Malvaceae & Alimentação \\
\hline Bananeira (Musa spp.) & Musaceae & Alimentação \\
\hline Mamoeiro (Carica papaya) & Caricaceae & Alimentação \\
\hline Urucu (Bixa orellana) & Bixaceae & Alimentação \\
\hline Arroz (Oryza sativa) & Poaceae & Alimentação \\
\hline Ingázeiro (Inga edulis) & Fabaceae & Alimentação \\
\hline Cheiro verde (Petroselinum crispum) & Apiaceae & Alimentação \\
\hline Couve galega (Brassica oleracea) & Brassicaceae & Alimentação \\
\hline Cariru (Talinum triangulare) & Talinaceae & Alimentação \\
\hline Bacurizeiro (Platonia insignis) & Clusiaceae & Alimentação \\
\hline Cafezeiro (Coffea arabica) & Rubiaceae & Alimentação \\
\hline Abacateiro (Persea americana) & Lauraceae & Alimentação \\
\hline Castanheira (Bertholletia excelsa) & Lecythidacea & Alimentação \\
\hline Hortelã (Mentha spicata) & Lamiaceae & Medicinal \\
\hline Arruda (Ruta graveolens) & Rutaceae & Medicinal \\
\hline Elixir paregórico (Piper callosum) & Piperaceae & Medicinal \\
\hline Pião (Jatropha curcas) & Euphorbiaceae & Medicinal \\
\hline Babosa (Aloe vera) & Xanthorrhoeaceae & Medicinal \\
\hline Chambá (Justicia pectoralis) & Acanthaceae & Medicinal \\
\hline Verônica (Veronica spicata) & Plantaginaceae & Medicinal \\
\hline Barbatimão (Stryphnodendron adstringens) & Fabaceae & Medicinal \\
\hline Jucá (Libidibia ferrea) & Fabaceae & Medicinal \\
\hline Boldo (Peumus boldus) & Monimiaceae & Medicinal \\
\hline Pluma (Celosia argentea) & Amaranthaceae & Medicinal \\
\hline Cacto (Stapelia hirsuta) & Apocynaceae & Ornamentação \\
\hline
\end{tabular}

Em termos estruturais da comunidade estudada, as famílias Arecaceae e Rutaceae apresentaram maior importância sociológica, visto que juntas compõem $23,4 \%$ das espécies que são utilizadas em prática alimentares. Das famílias Lamiaceae, Rutaceae e Fabaceae, juntas somam 5,4\% do total de espécies que são usadas para fins medicinais, quando relacionados com as outras famílias, sendo consideradas de alta importância sociológica.

A identificação florística e estrutural dos vegetais podem ser consideradas como o passo inicial para incrementar o conhecimento sobre a diversidade florística e justificar medidas de manejo e conservação para essas comunidades.

A agroecologia concebe o meio ambiente como um sistema aberto (LUHMAN, 1989), composto de diversos subsistemas interdependentes que configuram uma realidade dinâmica de complexas relações naturais, ecológicas, sociais, econômicas e culturais (HERRERO, apud COSTABEBER, 2012). No caso da agricultura, observa-se que ela deve ser construída sobre aspectos de conservação, alcançando características semelhantes às dos ecossistemas naturais e mantendo sua produtividade baseada num modelo econômico. Mas, para que isso aconteça, faz-se necessário, primeiramente, de uma nova consciência social 
a respeito das relações homem versus natureza.

Em prol desses pressupostos sobre agroecologia, foi elabora uma tabela com as respostas do questionário, referente as práticas de manejo e conversação do solo usadas na comunidade, podendo assim mensurar as frequências absolutas e relativas, com atrativo pedagógico para o entendimento de tais práticas e a relevância em grau de aplicabilidade (Quadro 1).

Quadro 1 - Práticas de melhoria da fertilidade do solo por ordem de frequência absoluta utilizadas pelos agricultores da comunidade de Santa Rosa, Capanema, Pará.

\begin{tabular}{|l|c|c|c|}
\multicolumn{1}{|c|}{ Práticas de manejo da fertilidade do solo } & Frdem & Fa) \\
\hline $\begin{array}{l}\text { Aplicação de esterco animal (Bovinos e Ovinos) nas } \\
\begin{array}{l}\text { áreas de } \\
\text { Cultivo }\end{array}\end{array}$ & $1^{\circ}$ & 10 & 19 \\
$\begin{array}{l}\text { Eliminação do fogo no } \\
\text { Preparo do solo (perda de nutrientes) }\end{array}$ & $2^{\circ}$ & 8 & 15 \\
\hline $\begin{array}{l}\text { Adubação verde com biomassa de espécies arbóreas } \\
\text { plantadas } \\
\text { como cercas vivas }\end{array}$ & $3^{\circ}$ & 7 & 13 \\
\hline $\begin{array}{l}\text { Plantio de árvores na propriedade } \\
\text { Plantio em nível }\end{array}$ & $4^{\circ}$ & 6 & 12 \\
\hline $\begin{array}{l}\text { Incorporação de } \\
\text { Resíduos vegetais após senescência }\end{array}$ & $4^{\circ}$ & 6 & 12 \\
\hline Adubação verde com plantas de ciclo curto & $5^{\circ}$ & 5 & 10 \\
\hline Plantio consorciado & $6^{\circ}$ & 4 & 8 \\
\hline Plantio de leguminosas ao redor dos roçados & $6^{\circ}$ & 4 & 8 \\
\hline Barramento das erosões com pedras & $7^{\circ}$ & 1 & 2 \\
\hline Período de pousio ou descanso das áreas & $7^{\circ}$ & 1 & 2 \\
\hline \multicolumn{1}{|c|}{ Ordem: } & 0 & 0 \\
\hline
\end{tabular}

Ordem: indica a posição da prática. $\mathrm{Fa}=$ Frequência absoluta. $\mathrm{Fr}=$ Frequência relativa

A partir de dados da tabela anterior foi possível montar algumas sugestões a serem tomadas pelos moradores da comunidade e apresentadas aos mesmo através de palestras, panfletagem e visitas, com intuito de divulgação dos dados processados no estudo, para diminuir práticas consideradas nãoagroecológicas, para que assim, haja o melhoramento de algumas práticas de manejo de fertilização dos solos já desenvolvidas pelas famílias e a eliminação de outras com potencial para degradação do meio ambiente. Algumas das práticas indicadas para serem tomadas como as mais frequentes foram Adubação verde com biomassa de espécies arbóreas plantadas como cercas vivas, Plantio de árvores na propriedade e Adubação verde com plantas de ciclo curto. Tais práticas podem ser muito favoráveis para o cultivo das espécies vegetais estudadas na comunidade, haja visto que, predispõem de conceito da agroecologia para a melhoria tanto da qualidade de vida como do ambiente em geral. Outras práticas como Eliminação do fogo no preparo do solo e Aplicação de esterco animal em compostagem nas áreas de cultivo, foram indicadas para serem reduzidas, com o preceito de que, as mesmas possam a vir causar algum dano para o solo, águas e ar (meio ambiente) e acarretar danos para a saúde humana. 


\section{CONCLUSÕES}

$\checkmark \quad$ A caraterização das espécies vegetais e sua importância para determinada comunidade, leva em conta diversas famílias e gêneros de vegetais dos seus mais variados tipos, indo desde espécies de arbustos, passando por espécies arbóreas, leguminosas e ervas medicinais.

$\checkmark \quad 0$ conhecimento das espécies presentes, sobre a diversidade florística pode justificar medidas de manejo e conservação para essas comunidades de forma mais eficiente.

A agroecológica resgata, sob novas bases tecnológicas e econômicas, a lógica da complexificação das sociedades camponesas tradicionais e seus conhecimentos desprezados pela agricultura moderna como forma de vencer o desafio de estabelecer uma agricultura sustentável.

Estudos como este tornam-se de fundamental importância para se ter uma melhor percepção acerca da manutenção da agricultura camponesa em comunidades rurais, a qual tem adquirido relevante papel na conservação do meio em que vivemos.

\section{REFERÊNCIAS}

[1] Altieri, M. Agroecologia: bases científicas para uma agricultura sustentável.

[2] Guaíba. Agropecuária, 2002.

[3] Anderson, A.B.; Gely, A.; Strudwick, J.; Sobel, G.L. \& Pinto, M.G.C. Um sistema agroflorestal na várzea do estuário amazônico (Ilha das Onças, Município de Barcarena, Estado do Pará). Acta Amazônica 15: 195-224, 1985.

[4] Caporal, F.R. et al. Agroecologia: uma nova ciência para apoiar a transição a agriculturas mais sustentáveis. In: Agroecologia: uma ciência do campo da complexidade. Brasilia, p. 9-64, 2009.

[5] Costabeber, J. A. Transição agroecológica: do produtivismo à ecologização. Disponível em http://www.ufsm.br/desenvolvimentorural/textos/32.pdf. Acesso em: 14/08/2012.

[6] Cunha, A. Fragmento de território de pesca na amazônia: comunidade Segredinho/Capanema-Pa. Dissertação (Mestrado em Gestão dos Recursos Naturais e Desenvolvimento Local na Amazônia) — Universidade Federal do Pará, Núcleo de Meio Ambiente, 2011.

[7] Gliessman, S. R. Agroecologia: processos ecológicos em agricultura sustentável. - 2ª ed. - Porto Alegre: Ed Universidade/UFRGS, 2001.

[8] Luhmann, N. Ecological Communication. Chicago: Polity Press, 1989.

[9] Marques, J. G. W. Pescando Pescadores: Etnoecologia Abrangente no Baixo São Francisco Alagoano. NupaubUSP. São Paulo/Maceió. Brasil. 304p, 1995.

[10] Neto, E.M.F. Seleção dos participantes da pesquisa. In: U.P. Albuquerque,

[11] R.F.P. Lucena, L.V.F.C. Cunha (eds). Métodos e Técnicas na Pesquisa Etnobiológica e Etnoecológica. Nupeea,Recife, p. 21-38, 2010.

[12] Santos, M. J. Projeto alternativo de desenvolvimento rural sustentável.

[13] Estudos Avançados. São Paulo: USP, v. 15, n. 43, p. 225-238, 2001.

[14] Santos, A. F. et al. Efeito residual da adubação orgânica sobre a produtividade do milho em sistema agroflorestal. Revista Brasileira de Engenharia Agrícola e Ambiental, v.14, n. 12, p. 1267-1272, 2010.

[15] Santo, A, S.; Oliveira, L.C.L; Curado F.F; Amorin, L.O. Caracterização e desenvolvimento de quintais produtivos agroecológicos na comunidade Men de Sá, Itaporanga d'Ajuda-Sergipe. Revista Brasileira de Agroecologia, 2013. 


\section{Bapítulo 12}

CONTROLE ALTERNATIVO DO FUNGO COLLETOTRICHUM GLOEOSPORIOIDES COM ÓLEOS ESSENCIAIS

\section{Luana Souza Silva}

Ana Paula Rodrigues da Silva

Tainara Rafaely de Medeiros

Grace Queiroz David

Walmor Moya Peres

Adriana Matheus da Costa Sorato.

Resumo: 0 trabalho teve como objetivo analisar o efeito de óleos essenciais de diferentes plantas para controle do crescimento do Colletotrichum gloeosporioides, fungo causador da doença conhecida como antracnose. 0 experimento de controle alternativo para esse agente causal foi desenvolvido em laboratório, utilizando os óleos essenciais de melaleuca, cravo, eucalipto, coco e menta hortelã, na concentração de 1\%, adicionados ao meio de crescimento (BDA) em placas. No centro das placas contendo BDA + óleo essencial, foi disposto um disco de $9 \mathrm{~mm}$ de diâmetro de uma cultura do fitopatógeno e posteriormente aferido o crescimento ao longo dos dias, tendo como base a testemunha, sem nenhum tipo de controle. Os óleos testados apresentaram ação fungistática, sendo considerados promissores no controle de C. gloeosporioides in vitro.

Palavras-chave: Efeitos residuais; opção natural; antracnose. 


\section{INTRODUCÃ̃O}

O uso de defensivos agrícolas vem crescendo muito nos últimos anos, isso se deve ao desenvolvimento da agricultura e abertura de novas áreas, ou seja, um crescimento proporcional à produção. Sem dúvida, o uso racional desses produtos podem ter, em curto prazo, efeitos positivos para o produtor. No entanto, em longo prazo, além do surgimento de fitopatógenos resistentes às substâncias químicas utilizadas, o ambiente é prejudicado devido aos seus efeitos residuais.

Os fungos do gênero Colletotrichum podem ser encontrado em regiões de clima tropical, subtropical e temperado (ARMESTO, C., 2013), e é um grupo de fitopatogênico considerado um dos mais importantes do mundo. 0 Colletotrichum gloeosporioides foi primeiramente relatado no Havaí e na Flórida, EUA. No Brasil esse patógeno tem sido relatado em vários estados, como no Ceará, Minas Gerais e São Paulo, entre outros (Ceres, A., 2005). A antracnose causada por espécies desse gênero é a principal doença observada na fase inicial na formação da vagem da soja, uma das culturas mais importantes para a economia brasileira. Além de afetar várias espécies de frutas na pós-colheita, como laranja, maracujá, pêssego, entre outras. Trata-se de uma doença geradora de grandes perdas, especialmente, em período quente e chuvoso, causando desfolha, seca de ramos e apodrecimento dos frutos (SILVA, A. C. da et al. 2009). 0 uso de óleos essenciais pode se tornar uma opção natural e menos agressiva para controle de fitopatogênicos, ou seja, um método alternativo para substituir ou diminuir o uso de caros defensivos agrícolas, atenuando a dependência desses produtos, gerando benefícios para o produtor e para o ambiente. Com intuito de colaborar para a geração de uma agricultura mais sustentável, esse estudo foi desenvolvido.

\section{MATERIAIS E MÉTODOS}

O experimento foi conduzido no Laboratório de Microbiologia e Fitopatologia da Universidade do Estado de Mato Grosso (UNEMAT), situado no Município de Alta Floresta - MT. O Colletrotrichum gloeosporioides foi obtido do mamão e isolado em laboratório. 0 estudo de controle consistiu em 6 tratamentos, com 5 repetições. Os óleos essenciais de melaleuca (Melaleuca alternifolia), cravo (Syzygium aromaticum), coco (Cocos nucifera), eucalipto (Eucalyptus), menta hortelã (Mentha) foram inseridos ao meio de cultura BDA (Batata Dextrose Ágar), e em todos os tratamentos o produto foi aplicado em concentração de 1\%, ou seja, 2,4 ml de óleo para $240 \mathrm{~mL}$ de BDA, junto com ele foi adicionado 0,1381g de antibiótico para evitar contaminação por bactérias, e acrescentado $1 \mathrm{ml}$ do espalhante adesivo (Nutrifix®), que contribuiu para homogeneizar o meio de cultura. Para a testemunha foi utilizado o mesmo procedimento, porém sem a inclusão dos óleos. Foram avaliados 5 tratamentos e comparado o crescimento ou inibição do crescimento micelial com a testemunha. Para o preparo do experimento verteu-se $12 \mathrm{ml}$ de BDA por placa em 60 placas de petri. Após a solidificação do meio foi disposto um disco de micélio fúngico ( $9 \mathrm{~mm}$ de diâmetro) na região central de cada placa para a avaliação do crescimento micelial do fungo, em seguida, foi traçado um eixo no verso da placa para a realização das medições. As placas foram acondicionadas em câmara de germinação (BOD) a $25^{\circ} \mathrm{C}$ com fotoperíodo de 12 horas por 7 dias, que foi o tempo necessário para que o fungo do tratamento testemunha crescesse, fechando totalmente a placa de petri. A avaliação do crescimento micelial consistiu da medição diária do diâmetro das colônias em dois sentidos perpendiculares, com auxílio de uma régua milimetrada, obtendo-se os valores médios de crescimento micelial. No final do experimento, tendo todas as medidas aferidas, os dados foram submetidos a analise através do teste estatítico de Tukey a $5 \%$ de significância.

\section{RESULTADOS E DISCUSSÃO}

Inicialmente os dados obtidos foram submetidos à análise de variância e ao constatar que os efeitos dos tratamentos eram estatisticamente diferentes procedeu-se ao teste de Tukey a 5\% de significância, o qual é apresentado na tabela 1 . 
Tabela 1. Médias referentes aos dias de inoculação do Colletotrichum gloeosporioides em diferentes compostos para controle alternativo

\begin{tabular}{|c|c|c|c|c|c|c|c|c|}
\multicolumn{1}{c|}{ Tratamento } & Dia 1 & Dia 2 & Dia 3 & Dia 4 & Dia 5 & Dia 6 & Dia 7 & IVCM (\%) \\
\hline (A) Melaleuca & $0 \mathrm{a}$ & $0,06 \mathrm{a}$ & $0,34 \mathrm{a}$ & $0,34 \mathrm{a}$ & $0,37 \mathrm{a}$ & $0,48 \mathrm{a}$ & $0,55 \mathrm{a}$ & $7,86 \mathrm{a}$ \\
\hline (B) Cravo & $0 \mathrm{a}$ & $0,22 \mathrm{ab}$ & $0,51 \mathrm{a}$ & $0,59 \mathrm{a}$ & $0,80 \mathrm{a}$ & $1,05 \mathrm{a}$ & $1,26 \mathrm{a}$ & $18,00 \mathrm{a}$ \\
\hline (C) Eucalipto & $0 \mathrm{a}$ & $0,30 \mathrm{~b}$ & $0,38 \mathrm{a}$ & $0,39 \mathrm{a}$ & $0,44 \mathrm{a}$ & $0,59 \mathrm{a}$ & $0,76 \mathrm{a}$ & $10,86 \mathrm{a}$ \\
\hline (D) Coco & $0 \mathrm{a}$ & $0,19 \mathrm{ab}$ & $0,42 \mathrm{a}$ & $0,49 \mathrm{a}$ & $0,57 \mathrm{a}$ & $0,84 \mathrm{a}$ & $0,94 \mathrm{a}$ & $13,43 \mathrm{a}$ \\
\hline (E) Hortelã & $0 \mathrm{a}$ & $0,25 \mathrm{ab}$ & $0,36 \mathrm{a}$ & $0,41 \mathrm{a}$ & $0,46 \mathrm{a}$ & $0,54 \mathrm{a}$ & $0,64 \mathrm{a}$ & $9,14 \mathrm{a}$ \\
\hline Testemunha & $0 \mathrm{a}$ & $1,54 \mathrm{c}$ & $3,84 \mathrm{~b}$ & $3,84 \mathrm{~b}$ & $4,81 \mathrm{~b}$ & $5,52 \mathrm{~b}$ & $5,99 \mathrm{~b}$ & $85,57 \mathrm{~b}$ \\
\hline
\end{tabular}

Médias seguidas de mesma letra minúscula na coluna não diferem pelo teste de Tukey ao nível de 5\% de significância.

IVCM: índice da velocidade do crescimento micelial.

Nota-se que a testemunha difere dos demais apresentando IVCM de 85,57\%, e os demais tratamentos são semelhantes, ou seja, apresentam em média a mesma velocidade de crescimento, que é considerada baixa.

Figura 1. (A): Tratamento com óleo de Melaleuca, IVCM de 7,86 \%; (B): Tratamento com óleo de Cravo, IVCM de 18 \%; (C): Tratamento com óleo de Eucalipto, IVCM de 10,86 \%; (D): Tratamento com óleo de Coco, IVCM de 13,46; (E): Tratamento com óleo de Menta Hortelã, IVCM de 9,14 \%; (F): Testemunha, sem óleo. IVCM de 85,57 \%.

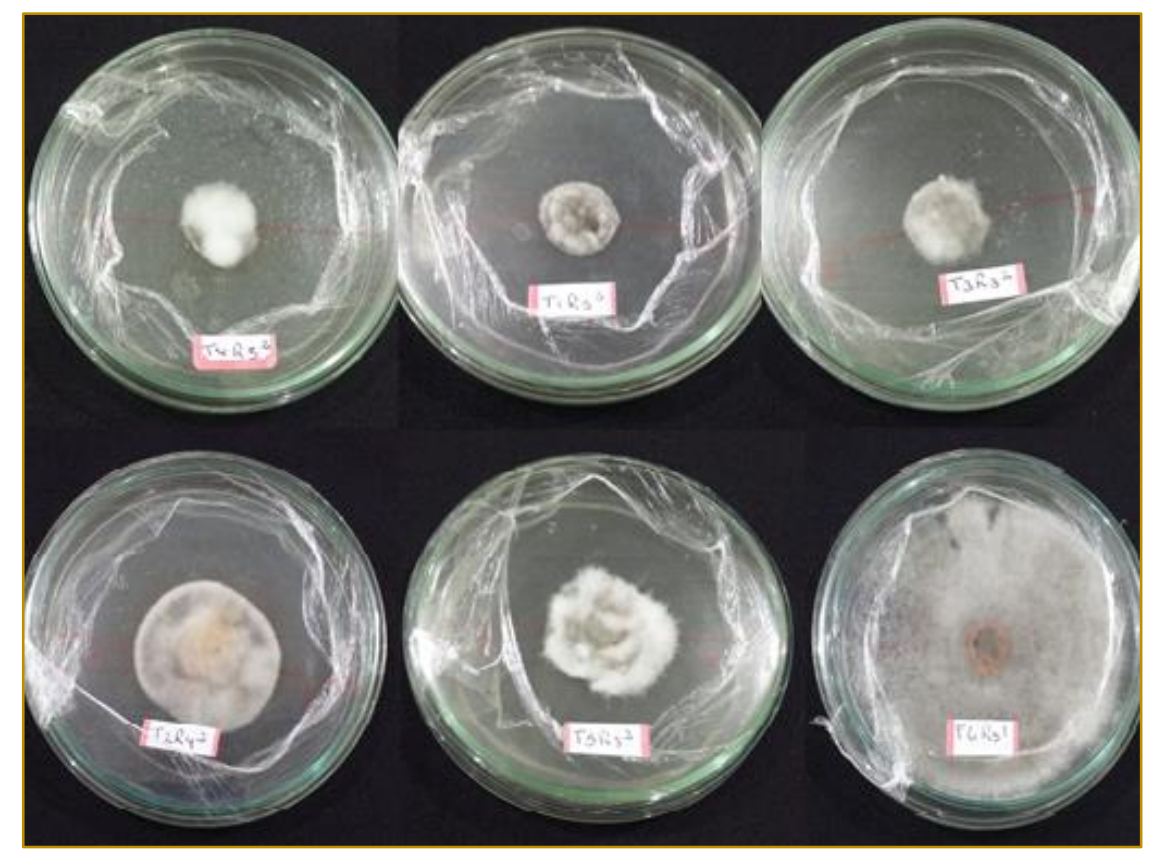

Ao verificar os diâmetros no decorrer dos dias de inoculação do patógeno, observa-se (Figura 1) que a testemunha (F) difere estatisticamente dos demais, apresentando maior diâmetro. Além disso, os demais tratamentos (A, B, C, D e E) apresentam comportamento semelhante quanto ao diâmetro, ou seja, em média, apresentam o mesmo diâmetro. Isso indica que todos os tratamentos analisados são promissores no controle do fungo analisado.

Martins et al. (2010), também obşırvaram a ação fungitóxica do óleo essencial de Melaleuca que inibiu o desenvolvimento dos fungos fitopatogênicos Macrophomina phaseolina, Sclerotinia sclerotiorum e Alternaria alternata podendo representar uma alternativa econômica e ecologicamente viável de controle de doenças de plantas.

O óleo de cravo mostrou ação antifúngica contra diversos fungos isolados de banana, Lasiodiplodia theobromae, Colletotrichium musae e Fusarium proliferatum (Ranashinge et al, 2002). Nos estudos desenvolvidos por Lorenzetti et al.(2011) sobre Botrytis cinerea em morango, o óleo de cravo mostrou-se eficaz na redução da germinação de conídios comprovando seu efeito fungitóxico. 
Souza et al. (2012) comprovaram o efeito fungicida do óleo de hortelã na concentração de $1 \%$ sobre o fungo Colletotrichum gloeosporioides oriundo de frutos de pimenta.

\section{CONCLUSÃO}

Os resultados indicam que os tratamentos analisados podem ser considerados eficientes, ou seja, com grande potencial fungistático, podendo ser utilizado como controle alternativo do Colletotrichum gloeosporioides gerando menos impacto ambiental, bem como um meio mais econômico para combater as doenças causas por essa espécie.

\section{REFERÊNCIAS}

[1] Armesto, Cecília. Variabilidade biológica e molecular de Colletotrichum gloeosporioides em cafeeiros / Cecília Armesto. - Lavras: UFLA, 2013.

[2] Ceres, A. Manual de fitopatologia / edição de Hiroshi Kimati [et al.] 4 ed. São Paulo: Agronômica Ceres, 2005.

[3] Silva, A. C. da et al. Efeito IN Vitro de Compostos de Plantas sobre o Fungo Colletotrichum gloeosporioides Penz. Isolado do Maracujazeiro. Ciênc. agrotec., Lavras, v. 33, Edição Especial, p. 1853 -1860, 2009. 


\section{Bapítulo 13}

\section{CONTROLE}

LARANJA 'PÊRA'

\section{Adriana Matheus da Costa Sorato}

Marcelo Solon Sicuto

Leila Maiara de Oliveira Corrêa

Daniel Carlesso

Grace Queiroz David

Tainara Rafaely de Medeiros

Resumo: Os citros são afetados por infestações fúngicas no pós-colheita, principalmente pelo gênero Penicillium, que acarretam diversos danos ao fruto. Assim, o objetivo desse trabalho foi analisar o efeito de tratamentos alternativos sobre Penicillium em pós colheita de laranja 'Pêra'. Foram selecionadas 30 laranjas em supermercado local, divididas em seis tratamentos, testemunha (sem agente de controle), água, hipoclorito de sódio, 30 min UV, 15 min UV e óleo de cravo, em cinco repetições. As laranjas sofreram higienização superficial com lavagem em água corrente, em seguida borrifadas com solução de esporos do fungo Penicillium, posteriormente submetidas aos tratamentos e alocadas em bandejas de polietileno, as quais foram armazenadas em sala de crescimento a $24 \pm 2^{\circ} \mathrm{C}$ e fotoperiodo de 12 horas. 0 nível de contaminação foi determinado visualmente, por um período de 4 semanas. 0 único tratamento promissor no controle de Penicillium em pós colheita de laranja 'Pêra' foi o hipoclorito de sódio.

Palavras-chave: Bolor verde; infestação; defensivo alternativo. 


\section{INTRODUCC̃̃O}

Dentre as frutas cítricas que fazem parte da alimentação do brasileiro, a laranja se destaca devido a sua importância comercial e aos seus compostos químicos benéficos ao organismo humano (COUTO; CANNIATTI-BRAZACA, 2010). A laranja 'Pêra', é uma cultivar amplamente produzida e apreciada no mercado, visto que apresenta sabor suave e adocicado (GROPPO et al, 2009), a qual pode ser consumida in natura ou destinada a industrialização.

Contudo, a comercialização do fruto in natura é limitada devido a problemas relacionados a pós-colheita, os quais causam danos na qualidade e quantidade de frutos e, em decorrência, perda econômica (NASCIMENTO et al, 2005). No pós-colheita, os frutos de laranja 'Pêra' podem ser acometidos por diversas doenças, devido a incidência de fitopatógenos (FISHER et al, 2007), dentre os quais o bolor verde (Penicillium digitatum) apresenta destaque (FORNER et al, 2013), pois reveste o fruto por uma espessa massa de esporos, que acarreta numa podridão mole (AZEVEDO, 2003).

Para controle do bolor verde é comum o uso de fungicidas, principalmente tiabendazol e imazalil (FISCHER et al, 2009). Contudo, o uso de tais produtos pode causar danos à saúde e ao meio ambiente, além de tornar o fungo mais resistente (FRANCO; BETTIOL, 2002). Dessa maneira, é crescente a procura de outros defensivos que sejam agroecológicos e proporcionem a produção de alimentos mais saudáveis (FISCHER et al, 2013).

Diversos produtos alternativos podem ser utilizados para efetuar esse controle de maneira eficiente. Franco e Bettiol (2002) comprovaram a eficiência de carbonato de Na e ácido bórico no controle de bolor verde. Shama e Alderson (2005) mostraram o efeito fungicida da aplicação de irradiação ultravioleta (UV) sobre citros. Já Forner et al (2013) concluíram que o tratamento térmico diminuiu a incidência e severidade da doença no pós colheita da laranja "Pêra".

Assim, esse trabalho teve como objetivo estudar o efeito de tratamentos alternativos sobre o fitopatógeno Penicillium em pós colheita de laranja 'Pêra'.

\section{MATERIAL E MÉTODOS}

As laranjas utilizadas nesse estudo foram obtidas em supermercado localizado no município de Alta Floresta - MT, situada nas coordenadas $09^{\circ} 53^{\prime} 02^{\prime \prime} \mathrm{S}$ e $56^{\circ}{ }^{\circ} 14^{\prime} 38^{\prime \prime} \mathrm{W}$, com extensão territorial aproximada de $9310,27 \mathrm{~km} 2$ (SMERMAN, 2007). Inicialmente as frutas foram desinfestadas de forma superficial com água corrente.

O isolado de Penicillium foi obtido de laranjas 'Pêra' adquiridas no mesmo supermercado. Depois de confirmada a patogenicidade, o fungo foi multiplicado em meio de cultura, para a produção de inoculo. Foi produzida uma solução de esporos, com cinco discos de Penicillium, triturados em liquidificador com acréscimo de água destilada, por $1 \mathrm{~min}$.

Em cada tratamento foram utilizados cinco frutos em cinco repetições. A inoculação ocorreu por borrifamento da solução de esporos em cada fruto, que permaneceram em repouso por 60 min para que a solução pudesse se instalar. Em seguida, os frutos foram submetidos aos agentes de controle: testemunha (sem agente de controle), água, hipoclorito de sódio, óleo de cravo (Syzygium aromaticum), 30 min UV e 15 min UV.

Para aplicar a água, foram utilizados 2 litros de água em balde, onde os frutos foram imersos e permaneceram nessa solução por 28 dias, período de duração do experimento. Para a aplicação de hipoclorito de sódio, as frutas foram imersas na solução por 30 min e posteriormente acondicionadas em bandejas e cobertas com plástico filme.

Para aplicação do terceiro tratamento, foi realizada uma mistura de $10 \mathrm{ml}$ de óleo de cravo com $100 \mathrm{ml}$ de água destilada e $1 \mathrm{ml}$ de espalhante adesivo. Tal solução foi alocada em bandeja, junto com as laranjas, sendo agitada por $5 \mathrm{~min}$, para total adesão, ficando em repouso por $30 \mathrm{~min}$, depois foi retirado o excesso da solução e coberto com plástico filme.

Para os tratamentos de exposição a UV, as laranjas contaminadas pelo fitopatógeno foram expostas a luz UV, pelo tempo conveniente de cada tratamento, acondicionadas em bandeja e cobertas com plástico filme. A testemunha, após a lavagem superficial inicial foi acondicionada em bandeja e coberta com plástico filme. Todos os tratamentos foram transportados para uma sala de crescimento, com temperatura de $24 \pm 2^{\circ} \mathrm{C}$ e fotoperíodo de 12 horas. 
As avaliações foram realizadas semanalmente por meio de observação visual, a partir da qual foram atribuídos valores aos níveis de contaminação, onde nível 0 indica $0 \%$ de contaminação; nível 1 indica contaminação entre 0\% e 10\%; nível 2 indica contaminação entre 10\% e 25\%; nível 3 indica entre 25\% e $50 \%$ de contaminação; nível 4 indica entre 50\% e 75\% de contaminação e nível 5 indica mais de 75\% de contaminação. Os dados coletados foram avaliados de forma subjetiva, utilizando análise descritiva.

\section{RESULTADOS E DISCUSSÃO}

Na primeira semana de avaliação não foi detectado contaminação em nenhum dos tratamentos. Na segunda semana de avaliação somente o hipoclorito de sódio e a exposição a luz UV por 15 min não apresentaram contaminação. Na terceira semana de avaliação, a testemunha apresentou nível máximo de contaminação, e o tratamento com água, nessa mesma semana, apresentou nível 4 de contaminação.

$\mathrm{Na}$ última semana de avaliação, as laranjas que não receberam agentes de controle (testemunha), apodreceram e foram totalmente contaminadas. As tratadas com água também apresentaram nível 5 de contaminação. 0 controle com óleo de cravo e com luz UV por 30 min também se mostraram ineficientes na quarta semana, visto que as laranjas tratadas com tais compostos apresentaram nível 4 de infestação. 0 tratamento com luz UV 15 min apresentou um grau de infestação um pouco menor, com nível 3 de contaminação, mas mesmo assim não é considerado eficiente. Já as laranjas tratadas com hipoclorito de sódio, não apresentou contaminação, se mostrando eficiente no controle desse fungo (Tabela 1)

Tabela 1 - Estatística descritiva do nível de contaminação de laranja 'Pêra' (pós colheita) submetidas aos tratamentos alternativos e também a quarta semana de avaliação. Laboratório de Microbiologia, Universidade do Estado de Mato Grosso, Alta Floresta - MT, 2017.

\begin{tabular}{|c|c|c|c|c|}
\hline Tratamento & Média & Menor & Maior & 4 Semana \\
\hline Hipoclorito de Sódio & 0 & 0 & 0 & 0 \\
\hline 15 min de UV & 1 & 0 & 3 & 3 \\
\hline 30 min de UV & 2 & 0 & 4 & 4 \\
\hline Óleo de Cravo & 2 & 0 & 4 & 4 \\
\hline Água & 2,25 & 0 & 5 & 5 \\
\hline & & & & \\
\hline Testemunha & 3 & 0 & 5 & 5 \\
\hline
\end{tabular}

Em média, o hipoclorito de sódio, não apresenta contaminação, contrário a testemunha, que apresenta nível 3 de contaminação (Tabela 1). Diversos trabalhos na literatura concordam com os resultados encontrados. Franco e Bettiol (2002) mostraram que a água não impede a inibição da germinação dos conídios do fungo $P$. digitatum, não sendo considerado um tratamento eficiente no controle do bolor verde em frutos de laranja. Basseto et al (2007), relataram a eficiência positiva da irradiação de luz UV para controle da podridão mole em pêssegos. A aplicação do extrato de cravo da índia não inibiu o crescimento de $P$. digitatum em laranja pós colheita em estudo realizado por Luchmann et al (2009).

De modo geral, o hipoclorito de sódio é usado no auxílio da desinfestação superficial dos frutos e não como tratamento alternativo ao bolor verde, mas é utilizado em experimentos relacionados a outras culturas, por exemplo, apresentou efeito fungicida eficiente, contra a ferrugem do cafeeiro (COSTA et al, 2007).

\section{CONCLUSÃO}

O único tratamento promissor no controle de Penicillium em pós colheita de laranja 'Pêra' foi o hipoclorito de sódio. 


\section{REFERÊNCIAS}

[1] Azevedo, C.L.L. Sistema de produção de citrus para o Nordeste. Embrapa Mandioca e Fruticultura - Sistema

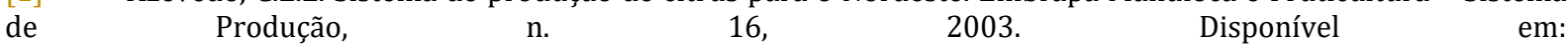
https://sistemasdeproducao.cnptia.embrapa.br/FontesHTML/Citros/CitrosNordeste/doencas.htm. Acesso em: 25 abr. 2017.

[2] Bassetto, E., Amorim, L., Benato, E.A., Gonçalves, F.P. \& Lourenço, S.A. Efeito da irradiação UV-C no controle da podridão parda (Monilinia fructicola) e da podridão mole (Rhizopus stolonifer) em pós-colheita de pêssegos. Fitopatologia Brasileira, v.32, n. 5, p. 393-399, 2007.

[3] Costa, M.J.N.; Zambolin, L.; Rodrigeus, F.A.; Avaliação de produtos alternativos no controle da ferrugem do cafeeiro. Fitopatologia Brasileira, v. 32, n. 2, p. 150-155, 2007.

[4] Couto, M.A.L.; Canniatti-Brazaca, S.G. Quantificação de vitamina C e capacidade antioxidante de variedades cítricas. Ciência e Tecnologia de Alimentos, v. 30, suplemento 1, p. 15-19, 2010.

[5] Groppo, V.D.; Spoto, M.H.F.; Gallo, C.R.; Sarmento, S.B.S. Efeito do cloreto de sódio na conservação de laranja 'Pêra' minimamente processada. Ciência e Tecnologia de Alimentos, v. 29, n. 1, p. 107-113, 2009.

[6] Fischer, I.H.; Toffano, L.; Lourenço, S.A.; Amorin, L. Caracterização dos danos pós-colheita em citrus procedentes de "packinghouse". Fitopatologia Brasileira, v. 32, n. 4, p. 304-310, 2007.

[7] Fischer, I.H.; Ferreira, M.D.; Sposito, M.B.; Amorin, L. Citrus postharvest diseases and injuries related to impacto n packing lines. Scientia Agricola, v. 66, p. 210-217, 2009.

[8] Fischer, I.H.; Palharini, M.C.A.; Sposito, B.; amorin, L. Doenças pós colheita em laranja 'Pêra' produzida em sistema orgânico e convencional e resistência de Penicillium digitatum a fungicidas. Summa Phytopathology, v. 39, n. 1, p. 28-34, 2013.

[9] Forner, C.; Bettiol, W.; Nascimento, L.M.; Terao, D. Controle em pós colheita de Penicillium digitatum em laranja pera com microorganismos e tratamento térmico. Revista Brasileira de Fruticultura, v. 35, n. 1, p. 23-31, 2013.

[10] Franco, D.A.S.; Bettiol, V. Efeito de produtos alternativos para o controle do bolor verde (Penicillium digitatum) em pós colheita de citros. Revista Brasileira de Fruticultura, v. 24, n. 2, p. 569-572, 2002.

[11] Luchmann, J.A.; Piva, A.L.; Santin, A.; Mazaro, S.M.; Junior, A. W.; Preparados de capítulos florais de cravo da índia (Syzygium aromaticum L.) e de folhas de pitangueira (Eugenia uniflora L.) como controle alternativo de podridões em frutos de laranja lima. III Seminário: Sistemas de produção agropecuária - Agronomia, 2009.

[12] Nascimento, L.M.; Santos, E.J.; Leozeni, A. Eficiência da Aplicação de Diferentes Doses de Fungicidas em Lima Ácida Tahiti, Laranja Pêra e Tangor Murcott para o Controle de Penicillium digitatum. Revista Iberoamericana Tecnológica Postcosecha, v. 7, n. 1, p. 41-47, 2005.

[13] Shama, G.; Alderson, P. UV hormesis in fruits: a concept rice for commercialisation. Trends in Food Science and Technology, v. 16, p. 128-136, 2005.

[14] Smerman, Wagner. Ictiofauna de riachos formadores do rio Teles Pires, drenagem do rio Tapajós, bacia Amazônica. 2007. Dissertação Mestrado Universidade Estadual Paulista, Centro de Aquicultura. Jaboticabal, 2007 


\section{Bapítulo 14}

\section{BIOATIVIDADE DO EXTRATO AQUOSO DE AÇAFRÃO NO DESENVOLVIMENTO MICELIAL DE PHYTOPHTHORA CAPSICI}

Ana Paula Rodrigues da Silva

Grace Queiroz David

Giseudo Aparecido de Paiva

Adriana Matheus da Costa Sorato

Walmor Moya Peres

Tainara Rafaely de Medeiros

Resumo: A utilização de defensivos agrícolas vem acarretando vários problemas à saúde humana e ao meio ambiente. Pensando nisto, o objetivo desse trabalho foi avaliar o controle alternativo, sobre o fitopatógeno Phytophthora capsici in vitro utilizando doses de extrato aquoso de açafrão. 0 experimento consistiu de 5 tratamentos com 5 repetições em delineamento inteiramente casualizado. As variáveis analisadas foram o índice de velocidade de crescimento micelial (IVCM) e porcentagem de inibição de crescimento (PIC). A análise estatística consistiu em uma análise de regressão linear. 0 maior IVCM foi observado para a testemunha, e o menor pela concentração $0,1 \%$, a partir da qual apresentou valores de IVCM crescentes para as demais doses. Para o PIC, as doses, exceto a testemunha, inibiram o crescimento do fungo. Desse modo, as doses testadas do extrato aquoso de açafrão se mostraram promissoras no controle do fitopatógeno Phytophthora capsici in vitro.

Palavras-chave: Doses, fitopatógeno, inibição, controle. 


\section{INTRODUCC̃̃O}

0 uso de defensivos agrícolas visa evitar a quebra de safras por ataque de pragas e doenças às culturas (Filho, 2004). Porém, essa atividade vem causando diversos impactos à saúde humana e ao ambiente (Soares, 2010). Devido a isso, é necessário a busca por formas alternativas de controle a essas patologias presentes nas culturas. Entre os métodos alternativos de controle, o biológico e a utilização de extratos de plantas vem sendo estudados nos últimos anos, apresentando avanços significativos na agricultura sustentável (Freitas, 2008).

O fungo Phytophthora capsici é um fitopatógeno de hortaliças responsável por grandes perdas no mundo todo. Causando doenças em diversas espécies de plantas, principalmente em plantação de morango, campos de abóbora e pimentão. Sua manifestação se dá em forma de podridão e mofo branco.

Segundo Viana et al (2007), o pimentão (Capsicum annuum) é uma das dez hortaliças mais importantes no país, e o Phytophthora capsici pode afetar todos os seus estágios de desenvolvimento, causando tombamentos das mudas, no caso de infectar as sementeiras, também o aparecimento de plantas murchas, principalmente nas horas mais quentes do dia.

Visando formas alternativas de controle que possam reduzir ou findar os impactos ambientais, o objetivo desse trabalho foi avaliar a ação antifúngica das doses de extrato aquoso de açafrão (Curcuma longa) sobre o fitopatógeno Phytophthora capsici in vitro.

\section{MATERIAL E MÉTODOS}

Este trabalho foi realizado no laboratório de Microbiologia e Fitopatologia da Universidade do Estado de Mato Grosso, Campus de Alta Floresta - MT. Para realização do experimento utilizou-se isolados do fungo Phytophthora capsici obtidos do pimentão (Capsicum annuum) e extrato aquoso de açafrão, em diferentes doses, sendo a testemunha $0 \%$, e as demais $0,1 \%, 0,5 \%, 1 \%$ e $2 \%$. 0 experimento consistiu de 5 tratamentos com 5 repetições, em delineamento inteiramente casualizado.

As dosagens de extratos foram incorporadas ao batata dextrose ágar fundente, acrescido de $0,150 \mathrm{~g}$ de antibiótico Amoxicilina e $1 \mathrm{ml}$ de espalhante adesivo CLEANNER FLY para cada erlenmeyer com $300 \mathrm{~mL}$ de meio de cultura. Para testemunha foi utilizado o mesmo procedimento porém sem adição do extrato de açafrão. Foram avaliados os efeitos das doses e comparado o crescimento ou inibição do crescimento micelial com a dose $0 \%$ (testemunha). Na montagem do experimento foram depositados $12 \mathrm{ml}$ de BDA já com os extratos de açafrão em placas de petri de 90x15mm.

Após solidificação do meio foi disposto um disco de micélio fúngico com $9 \mathrm{~mm}$ de diâmetro no centro da placa. Para avaliação do crescimento do fungo Phytophthora capsici, traçou- se um eixo no verso das placas. Os tratamentos foram acondicionados em câmara de germinação BOD a $25^{\circ} \mathrm{C}$ com foto período de 12 horas por 5 dias. A análise do crescimento micelial consistiu na medição diária do diâmetro das colônias em dois sentidos perpendiculares, com auxílio de uma régua milimetrada. As variáveis analisadas formam o índice de velocidade de crescimento micelial (IVCM), conforme fórmula descrita por Oliveira (1991).

$$
\operatorname{IVCM}=\Sigma(\mathrm{D}-\mathrm{Da}) / \mathrm{N}
$$

Sendo:

IVCM= índice de velocidade de crescimento micelial

$\mathrm{D}=$ diâmetro médio atual da colônia

$\mathrm{Da}=$ diâmetro médio da colônia do dia anterior

$\mathrm{N}=$ número de dias após a inoculação. 
E também a porcentagens de inibição do crescimento micelial (PIC), dado por: Os dados foram inicialmente submetidos a análise de variância, e por se tratar de doses crescentes, após constatação de significância do teste $F$, foi realizada análise de regressão linear, considerando o coeficiente de determinação como medida da qualidade de ajuste. As análises e a construção gráfica foram realizadas com o auxílio do software livre R (R Development Core Team, 2017).

\section{RESULTADOS E DISCUSSÃO}

A porcentagem de inibição do crescimento micelial (PIC) do fitopatógeno na ausência de extrato de açafrão (testemunha) é menor que nas demais doses testadas, apresentando 0\% de inibição.

Para as demais dosagens $(0,1 \%, 0,5 \%, 1 \%$ e $2 \%)$, os valores de PIC são elevados, com variação entre $70,32 \%$ e $85,71 \%$, para o extrato com $2 \%$ e $0,1 \%$ de açafrão, respectivamente (Figura 1). Isso significa que o extrato de açafrão, nas concentrações testadas, apresenta controle significativo do fitopatógeno, e as doses $(0,1 \%, 0,5 \%, 1 \%$ e $2 \%)$ não apresentam diferença entre si.

Resultados semelhantes foram obtidos por Takatsuka et al. (2003), em experimento utilizando o extrato bruto de açafrão (Curcuma longa), em condições laboratoriais análogas. Amaral e Bara (2005), mostraram que o açafrão aplicado na concentração $1 \%$ inibiu o crescimento micelial em $61,15 \%$ de $F$. oxysporum e em $61,10 \%$ em $R$. solani.

Figura 1- Análise de regressão linear do Percentual de Inibição do Crescimento (PIC) do fungo Phytophthora capsici em função de diferentes doses de extratos de açafrão, equação da reta de regressão e medida da qualidade de ajuste.

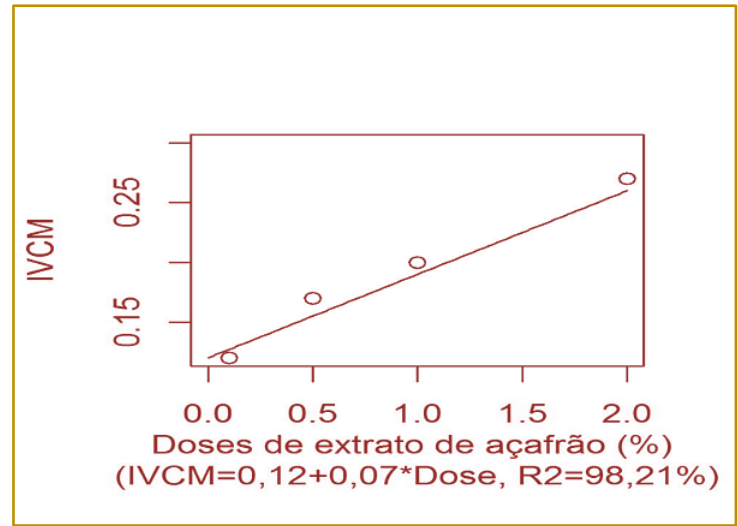

Ao avaliar o índice de velocidade de crescimento (IVCM), o resultado foi semelhante ao visto no PIC, já que a testemunha apresenta maior valor de $\operatorname{IVCM}(0,91)$ que os demais, valor que indica rápido crescimento do fungo em questão, o qual colonizou toda a placa em cinco dias, ou seja, na ausência de açafrão o fungo apresenta proliferação acelerada.

Além disso, para as demais doses avaliadas observa-se um comportamento linear crescente do IVCM, com menor valor de IVCM apresentado pela menor dose e maior valor apresentado pela maior dose. Isso indica que na menor dose do extrato a velocidade do crescimento é menor que para as doses maiores (Figura 2). Ou seja, na menor concentração é observado maior inibição do crescimento do fungo.

Este fato foi observado nos estudos de Nascimento et al. (2014), onde o óleo de Cedro apresentou PIC de $53,36 \%$ na menor dose $(25 \mu \mathrm{L})$ e $49,77 \%$ na dose intermediária $(45 \mu \mathrm{L})$ e reduziu a inibição do crescimento para $47,08 \%$ para uma dosagem alta $(75 \mu \mathrm{L})$. 
Figura 2- Regressão linear do Índice Velocidade de Crescimento Micelial (IVCM) do fungo Phytophthora capsici em função de diferentes doses de extratos de açafrão, equação da reta de regressão e medida da qualidade de ajuste.

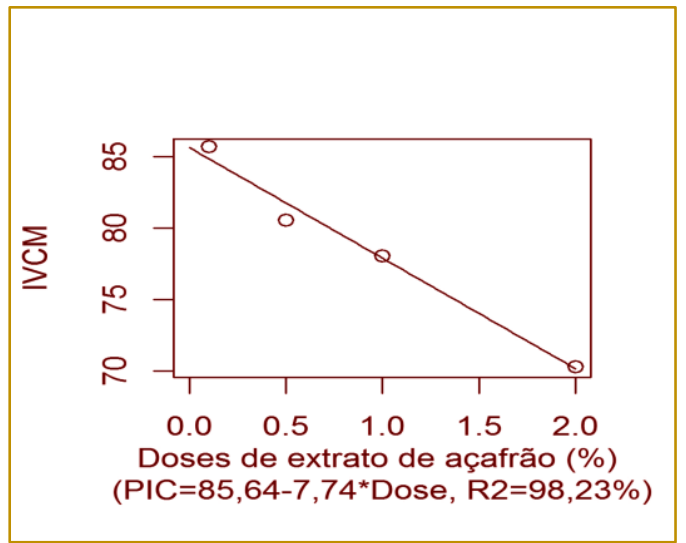

O controle alternativo feito com extrato de açafrão é amplamente estudado por conta da sua conhecida ação antifúngica (Mioranza et al, 2017). Balbi-Peña et al (2006), comprovaram a eficiência do extrato de açafrão bruto no controle alternativo do fungo Alternaria solani em frutos de tomate.

\section{CONCLUSÃO}

As doses testadas do extrato aquoso de açafrão foram consideradas promissoras no controle do fitopatógeno Phytophthora capsici in vitro, desta forma, constitui uma alternativa viável ao tratamento químico deste patógeno.

\section{REFERÊNCIAS}

[1] Amaral, M.F.Z.J.; Bara, M.T. Avaliação da atividade antifúngica de extratos de plantas sobre o crescimento de fitopatógenos. Revista eletrônica de farmácia, v. 2, n. 2, p. 5-8, 2005.

[2] Balbi-Peña, M.I.; Becker, A.; Sangarlin, J.R.; Franzener, G.; Lopes, M.C.; Schwan-Estrada, K.R.F. Controle de Alternaria solani em tomateiro por extratos de Cúrcuma longa e curcumina - II. Avaliação in vivo. Fitopatologia Brasileira, v. 31, n. 4, p. 401-404, 2006.

[3] Filho, E. L. B.; Impactos Ambientais Ocasionados pelo Uso de Defensivos Agrícolas: a Escassez de Pesquisas no Programa Nacional de Pesquisa Agropecuária Brasileiro. (Instituto de Economia/UNICAMP), 2004.

[4] Freitas, L. G.; Controle alternativo de nematoides. XLI Congresso Brasileiro de Fitopatologia. Tropical Plant Pathology. Brasília, v. 33, p. 34-36, 2008. Suplemento.

[5] Mioranza, T.M.; Stangarlin, J.R.; Kuhn, O.J.; Portz, R.L.; Balbi-PEÑA, M.I.; Schwan-Estada, H.M.; Viecelli, C.A.; Dal'maso, E. G.; meunerz, C.C. Biological properties of tumeric. Scientia Agraria Paranaensis, v. 16, n. 1, p. 1-12, 2017.

[6] Nascimento,D.M;Vieira,G.H.C;Batista,T.B; Koyanagui,M.T; Bardiviesso, E.M; Efeito de óleos essenciais sobre o crescimento micelial in vitro de fusarium solani f.sp glycines. Enciclopédia Biosfera - Centro Científico Conhecer, Goiânia, v.10, n.19; p. 874-881, 2014.

[7] R Developemnt Core Team. R: A language and enviroviment for statistical computing, 2017. Disponível em: https://www.r-project.org/. Acesso em: 10 jun. 2017.

[8] Soares, W. S. Uso dos agrotóxicos e seus impactos à saúde e ao ambiente: uma avaliação integrada entre a economia, a saúde pública, a ecologia e a agricultura. 2010. Tese. (Doutorado em Ciências na área de Saúde Pública e Meio Ambiente) - Escola Nacional de Saúde Pública Sergio Arouca, Rio de Janeiro, 2010.

[9] Takatsuka, F. S., I. D; Silva, M. F; Oliveira, C; Czepak, C. M. A; Oliveira \& M. G. Cunha. Efeito do óleo essencial açafrão (Curcuma longa) sobre o desenvolvimento micelial de fungos. In: Congresso Brasileiro de Fitopatologia, Uberlândia, Minas Gerais, 2003, p. 5350.

[10] Viana, F. M. P.; Freire, F. C. O.; Parente, G. B.; Controle das Principais Doenças do Pimentão Cultivado nas Regiões Serranas do Ceará. Fortaleza: Embrapa, 2007, 4p. (Embrapa Agroindústria Tropical, Comunicado Técnico, 132). 


\section{Bapítulo 15}

PERCEPÇÕES DO FAZER NA AGRICULTURA ECOLÓGICA: AS CONTRADIÇÕES DA "ROÇA LIMPA" E DA "NÃO LIMPA"

\section{Iara Aquino Henn}

Serinei César Grigolo

Resumo: 0 presente estudo se ocupa em analisar a relação dos agricultores e agricultoras com a natureza no contexto da agricultura ecológica a partir de conflitos "roça limpa" e "roça não limpa". Tais expressões, que no artigo apresentamos como queixas, devem-se as críticas advindas do modo convencional de fazer agricultura, que classificam aos agricultores ecológicos como "burros" ou "loucos" por não utilizarem em suas unidades familiares agrotóxicos. Para isso, procedeu-se visitas a grupos familiares agroecológicos da região sudoeste do Paraná, objetivando compreender o cotidiano de agricultores e agricultoras. Entre as diversas informações da prática de fazer agricultura ecológica, o tema "roça limpa" e "roça não limpa" emergem como resultante de conhecimentos distintos e a defesa de tais práticas são justificativas para a sustentação da tensão entre agricultura ecológica e a convencional.

Palavras-chave: Agrotóxicos; agroecologia; manejos; trabalho. 


\section{INTRODUCC̃̃O}

0 artigo situa-se nos debates epistemológicos da agricultura ecológica e nas análises da antropologia social, com aportes etnográficos, a qual desvela as percepções e conflitos em torno das expressões "roça limpa" e "roça não limpa". Tais categorias revelam tensões entre dois modelos de agricultura, a partir da percepção dos próprios agricultores/as, no qual o "limpo" e o "não limpo" figuram como categorias de análise deste estudo. Contudo, o objetivo é compreender os conflitos resultantes de um conjunto de manejos e conhecimentos que são explicados e debatidos entre seus pares e mediadores. Tal debate tem aporte na interface com o conhecimento científico e tradicional versus os conhecimentos da agricultura moderna.

0 presente artigo se justifica porque na região sudoeste do Paraná existem inúmeras experiências desenvolvidas no campo da agricultura ecológica, mediadas por processos locais de formação de agricultores/as desenvolvidos por organizações da agricultura familiar e camponesa. Conflitos desta natureza são frequentemente abordados, contudo, nem sempre se consegue fundamentar a partir das visões dos interlocutores/as. Pois, estas percepções são relatadas a partir de processo vivenciados que abrangem desde a gênese da agricultura ecológica e todo seu percurso até a luta por políticas públicas. Todavia, este artigo contribui para evidenciar e colocar em relevância os aspectos epistemológicos da agroecologia, demonstrando que contraditoriamente a base de conhecimentos pautados pela agricultura moderna, existem outros que se fundamentam nos princípios da autonomia e da emancipação.

Durante a escrita da investigação, as ideias de Turner (2008, p. 37) problematizaram nossa percepção para o curso das ações sociais, os conflitos e as tensões gerados por estes coletivos de agricultores/as. Os diferentes manejos que adotam, e os conhecimentos que o embasam, atribuindo a agroecologia o termo "roça não limpa" e a agricultura convencional o termo "roça limpa", entendendo esse conflito, como contribuições ao debate dos conhecimentos agroecológicos. Pois, tais categorias podem ser compreendidas como geradores de movimentação, de organização e de conhecimentos, com poder de fazer com que velhas regras sejam abolidas e bases de sustentação política sejam alteradas ou problematizadas na categoria dos conhecimentos e tecnologias.

\section{MATERIAL E MÉTODOS}

Explorar-se-á falas com interlocutores obtidas em uma pesquisa de campo de cunho qualitativo, realizada no sudoeste do Paraná, região de agricultura familiar e com organizações sociais que se mobilizam pela agroecologia. A pesquisa etnográfica buscou nas práticas, discursos, técnicas, ações e manejos realizados as tensões, no sentido empreendido por Wolf, com a tarefa de "decifrar as complexidades, as heterogeneidades e as desigualdades [...]" (FELDMAN-BIANCO e RIBEIRO, 2003, p. 12).

Com o enfoque etnográfico, como método de investigação, realizamos a construção de 20 trajetórias de vida de grupos familiares de agricultores/as situados na região Sudoeste do Paraná (dados biográficos, sociais e culturais) como fio condutor da investigação e elegemos os seguintes interlocutores/as: grupos familiares ecológicos, mediadores que atuam nas organizações sociais da Agricultura Familiar, agricultores/as feirantes, agricultores/as em transição para a agroecologia e egressos do Curso de Pós Médio do Curso Técnico de Agroecologia organizados pela Associação de Estudos, Orientação e Assistência Rural (Assesoar). Deste modo, o produto final da investigação resultou da combinação de três fontes de dados: entrevistas abertas e reconstrução das trajetórias biográficas (história produtiva, social e cultural); observação e entrevistas com os mediadores/as (organizações e técnicos que promovem práticas e representações agroecológicas); observação de situações de interação entre mediadores/as e agricultores/as (cursos, capacitações, eventos, dias de campo, entre outros). Usamos o programa Software profissional para pesquisa qualitativa e métodos mistos MaxQda para a análise de dados, categorizando as falas em torno de categorias delineadas a partir das leituras bibliográficas e da análise das falas dos interlocutores/as, do qual resultaram as categorias analisadas no artigo.

\section{RESULTADOS E DISCUSSÃO}

É significativo o relato do Sr. Interlocutor A, que ao falarmos do propósito em investigar como se organiza o cotidiano dos agricultores/as ecológicos/as, logo reagiu: “... Pode vim, só não vai apavorar e pensar como meus vizinhos que dizem que não sabem como que consigo viver no meio do mato".

As tensões e contradições: "roça limpa" e "roça não limpa" podem ser também apreendidas na fala desta senhora agricultora agroecológica: 
Ah sim, mas Deus o livre! Aqueles que não planta orgânico, eles dizem: "Mas eu que vou ficar nesse sol carpindo, passa um veneno e depois senta na sombra tomar um chimarrão". Mas eu, também digo assim: "_ eu também sento na sombra, tomo meu chimarrão, depois pego o meu chapéu e vou pra roça". Não precisa ir, não tem necessidade de ir nos horários de sol quente e coisa, [risos]. Pra manter uma roça assim, não é que é tão trabalhoso. E hoje as roças mais limpas que têm são as orgânicas aqui na nossa região, os químicos, que passam todo aquele veneno, ainda quando vão colher tem mato dentro das plantas, que é horrível. (INTERLOCUTORA B - agricultura ecológica).

Em diversos locus do campo etnográfico apareceram falas emblemáticas como da Sra. Interlocutora B. Por exemplo, o Sr. Interlocutor C, relatou que os vizinhos o chamam de "louco" quando o veem fazendo trabalhos manuais. Mas, esta queixa vai além destas duas situações. O Sr. Interlocutor D, de Dois Vizinhos, relatou que seu filho estava capinando na beira da estrada quando o vizinho passou e disse: "[...] larga mão de sofrer home! [...] compra aí um litro de veneno que mata tudo". O Interlocutor E, relatou ouvir mais de dez agricultores lhe falarem para "deixar dessa bobagem e passar veneno".

A interlocutora B, assegura que, em relação ao sistema convencional, não acha difícil manter a roça nas condições necessárias para produzir orgânico. Aprendeu que para ter a roça corrigida é necessária "uma boa cobertura verde" no inverno, cobertura de palha para controlar as plantas espontâneas, entre outros manejos que utiliza, inclusive na produção dos grãos. Relata que essas aprendizagens advêm da participação em processo de formação nas organizações sociais da região.

Para a Sra. Interlocutor F, do município de Francisco Beltrão, feirante, ver a horta com cobertura verde não é fácil, mesmo sabendo que é uma prática da agroecologia e ter comprovado que produz melhor, uma vez que protege a terra, mantém a umidade e desvia atenção dos insetos de suas culturas, garantindo o equilíbrio do ambiente. Todavia, relatou-nos que às vezes sente-se mal diante de outras pessoas que a criticam ou fazem "brincadeiras" perguntando-lhes se não tem tempo para capinar o mato, que sua horta está no "meio da sujeira". Também assinalou que tem dificuldade, ainda hoje, de gostar de sua plantação em meio as plantas espontâneas, pois aprendeu que "terra limpa" é sinônimo de boa produção e trabalho bem feito.

Parece-nos que os manejos para fazer da roça um cenário alinhado, com terra exposta, como sinal de rendimentos e de agricultor/a que trabalha, estão impregnados nas percepções e mesmo quando desconstruídos nos processos educativos deixam nuances evidenciadas pelos relatos.

A problemática, a qual descortina a tensão que perpassa pensamentos e discursos em relação a ser um agricultor/a ecológico/a ou não, está ancorada também nos conflitos em relação aos manejos que se necessita fazer, ora pela cultura que possuem, a exemplo da concepção da terra limpa e dos plantios alinhados, ora pelas formas e instrumentos que dispõem para fazer os manejos e organizar sua produção, principalmente nas fases de transição ou conversão do sistema convencional para o agroecológico. A Interlocutora G é mediadora, ou seja, possui formação em agroecologia, relatou as dificuldades que sua mãe tem em aceitar que o "pomar" seja organizado com base na prática agroflorestal, pois esteve sempre acostumada com a "terra limpa".

Estas "queixas" descortinam uma diversidade de concepções sobre o fazer num modelo de agricultura e no outro. Está em jogo, em meio às tensões, o significado imputado a roça limpa ou não limpa. Para explicitar os resultados, tomamos emprestado de Mary Douglas (1966) as categorias de puro/impuro, da ordem/desordem, que se opõem e estão intrínsecos a uma organização ou ordem social construída, a partir da qual problematiza os conflitos e as práticas instituídas. Adotando este conceito da autora no sentido de uma ferramenta de pensamento (WOLF, 2003), na agricultura ecológica, "a desordem é pois, ao mesmo tempo, símbolo de perigo e poder" (DOUGLAS, 1966, p. 115).

Os espaços (BOURDIEU, 2007) caracterizados imersos "no meio do mato"; na "roça não limpa"; na "roça suja" se misturam nas falas, pois mostram as diferenças de percepções sobre o que constitui a categoria da agroecologia. Não alinhados, não medidos e nem ordenados, segundo a lógica moderna de fazer agricultura, estes espaços se constituem uma "desordem" e têm potencialidades no sentido que atribui Mary Douglas. Com esse relato passamos a compreender um pouco mais sobre as críticas que agricultores/as agroecológicos/as recebem de outros agricultores/as relativos a suas roças "não limpas". 


\section{CONCLUSÃO}

Em suma, nas tensões do campo etnográfico sobre "roça limpa" e "roça não limpa", identificamos que os conflitos entre conhecimentos distintos e contraditórios descortinam um campo epistemológico em construção próprio da agricultura ecológica. Os agricultores/as que são participantes de processos de educação há mais tempo e engajados em organizações da Agricultura Familiar, refletem, argumentam e analisam sua forma de fazer agricultura, destacando alternativas tanto na produção, quanto nas relações ambientais. Portanto, destacamos estes elementos como estratégias de adaptação, apontadas por Bartolomé (2000, p. 27), como um movimento, o qual não é absoluto e não está totalmente determinado pelas forças externas, mesmo sendo inegáveis as limitações sociais, econômicas e culturais.

Neste sentido, os interlocutores/as deste estudo demostraram que é possível encontrar alternativas para modificar posições e formas de fazer sua produção ao ponto de sentir aceitável ou viável em relação às condições do grupo familiar e social. Reinventar e construir estas estratégias (DE CERTEAU, 2007) possibilitou aos agricultores/as gerar outras formas sociais, econômicas e culturais no jeito de ser e fazer a agricultura ecológica como um processo em construção (roça não limpa).

Resultantes dessas posições, os manejos realizados e debatidos com os pares e mediadores/as geram uma série de práticas ecológicas distintas da agricultura moderna, a exemplo dos consorciamentos de culturas, das adubações verdes, das coberturas de solo, das plantas alelopáticas e repelentes (roça não limpa), que adotam para manejo da fertilidade e da sanidade do sistema. Evidenciando, assim, uma gama de conhecimentos e tecnologias que contribuem para sua profissionalização entrelaçados a preservação ambiental, geração de renda e produção com outras bases epistemológicas.

Portanto, o "limpo" e o "não-limpo"; a "ordem" e a "desordem" são conflitos ligados aos processos de conhecimentos em disputa e, consequentemente, às práticas em construção, de forma tensa e ao mesmo tempo complexa que contribuem para fazer emergir a agricultura ecológica como uma prática social além de sustentar as práticas de enfrentamentos, resistências e a geração de outros conhecimentos, todavia, ainda incipientes.

\section{AGRADECIMENTOS}

À Dra a Gabriela Schiavoni orientadora de tese "Atores de Conhecimento e Intervenção: a Construção Social da Agricultura Ecológica" que deu origem a esse debate. Professora do PostgradoemAntropologia Social, Universidad Nacional de Misiones, Posadas, Argentina.

Observação: artigo apresentado ao X Congresso Brasileiro de Agroecologia e publicado nos Anais do VI CLAA, X CBA e V SEMDF - Vol. 13, № 1, Jul. 2018 (Cadernos de Agroecologia).

\section{REFERÊNCIAS}

[1] Bartolomé, Leopoldo J. Los colonos de Apóstoles: estrategias adaptativas y etnicidaden una Colonia Eslava de Misiones. Posadas, Argentina: Universidad Nacional de Misiones, 2000. 286 p.

[2] Bourdieu, Pierre. Efeitos do lugar. In: Miséria do Mundo. 6. ed. Petrópolis: Vozes, 2007. p. 159-166.

[3] De Certeau, Michel de. A invenção do cotidiano. 13ạ. ed. Petrópolis: Vozes, 2007. 372 p.

[4] Douglas, Mary. Pureza e Perigo: ensaio sobre as noções de poluição e tabu. Tradução Sônia Pereira da Silva. Lisboa: Edições 70, 1966. 232 p. (Coleção. Perspectivas do Homem, n. 39)

[5] Feldman-Bianco, Bela; Ribeiro, Gustavo Lins. In: (Org.). Antropologia e Poder: as contribuições de Eric Wolf. Tradução de Pedro Maia Soares. Brasília: Universidade de Brasília, 2003. p. 11-55.

[6] Turner, Victor. Dramas, campos e metáforas: a ação simbólica na sociedade humana. Tradução Fabiano de Morais. Niterói, RJ: Universidade Federal Fluminense, 2008. 78 p. (Coleção Antropologia e Ciência Política, 42).

[7] wolf, Eric R. Explicando a vida rural: Tipos de Campesinato latino-americano: uma discussão preliminar, Comunidades camponesas corporadas fechadas na Mesoamérica e em Java Central. In: Feldman-Bianco, Bela; Ribeiro Gustavo Lins. Antropologia e Poder: as contribuições de Eric Wolf. Brasília: Universidade de Brasília, 2003. 276 p. (Coleção Antropologia). 


\section{Bapítulo 16}

\section{PARTICIPAÇÃO DA JUVENTUDE RURAL DA ESCOLA FAMIILIA AGRÍCOLA DE ORIZONA EM SISTEMAS AGROECOLÓGICOS}

Vanislene Borges da Silva

João Torres Franco Borges Lima

Renata Pires Batista

Wilson Mozena Leandro

Warde Antonieta da Fonsceca Zang

Resumo: 0 presente trabalho objetivou a compreensão da Escola Família Agrícola de Orizona (GO) - EFAORI, uma experiência de educação alternativa às convencionais, direcionada aos jovens do campo. As EFAs surgiram na França na década de 1930 e chegaram ao Brasil no estado do Espírito Santo na década de 1960, aliada à luta dos movimentos sociais pela terra e por igualdade da educação do campo. Logo a experiência espalhou-se por todas as regiões do Brasil, no final da década de 1990 foi fundada a EFAORI, localizada no município de Orizona (GO) a $138 \mathrm{~km}$ de Goiânia. 0 Objetivo das EFAs é propiciar condições para que os jovens permaneçam dignos no campo. Á metodologia utilizada, parte do princípio do qual os estudantes revezam escalas semanais, onde permanecem uma semana na escola, em regime de internato e uma semana na propriedade aplicando os conhecimentos adquiridos durantes as aulas. A integração escola/meio social possibilita a formação integral dos jovens, levando em conta sua realidade atual. 0 trabalho desenvolvido é voltado para recuperação do solo, as ações contaram com jovens dos municípios do Território da estrada de ferro matriculados no $2^{\circ}$ e $3^{\circ}$ ano. Esta mobilização possibilitou a participação da juventude em ações como revisão teórica sobre a utilização do adubo verde, com a realização de um croqui para a implantação de um experimento do mesmo. Em aulas práticas, foi abordada a necessidade da análise do solo, onde os alunos obtiveram atividades sobre amostragem de solo. 0 projeto possibilitou a implantação de um corredor agroecológico.

Palavras-chave: permanência no campo, manejo agroecológico do solo, desenvolvimento local. 


\section{CONTEXTO}

Consciente da importância da Juventude Rural, o Território da Estrada de Ferro se mobiliza para essa participação da juventude em processos de produção agroecológico, envolvendo discentes da Escola Família Agrícola de Orizona que atende o Território. Ele é composto por quatorze municípios (Bonfinópolis, Bela Vista de Goiás, Caldazinha, Leopoldo de Bulhões, Cristianópolis, Gameleira de Goiás, Orizona, Palmelo, Pires do Rio, Santa Cruz de Goiás, São Miguel do Passa Quatro, Silvânia, Urutaí e Vianópolis) tem atuado no sentido de fomentar uma Educação pautada na realidade do campo.

Alguns trabalhos de pesquisa constatam a "destruição" do tecido social nas comunidades rurais, associando de maneira causal a desagregação do ambiente cultural ao esvaziamento demográfico, particularmente de jovens. 0 processo migratório é visto como um movimento de mão única, determinado sobre tudo por causas externas. Esta causalidade é que estamos pondo em questão. A produção da exclusão social no espaço rural não se restringe apenas aos cenários macroeconômicos e políticos externos, uma vez que a "construção social" da desigualdade de condições se opera também por agentes e instituições que, frequentemente, se encontram bastante próximo da realidade das famílias rurais e, em particular, das hierarquias vigentes no interior desses mesmos grupos sociais (STROPASOLAS, 2009). Stropasolas relata que manifestações culturais das comunidades rurais revestem de grande importância no processo de socialização desses jovens, e devem ser envolvidas nas iniciativas e projetos implementados pelas entidades governamentais ou pelas organizações não governamentais. Para isso, os diversos programas deveriam apoiar a instalação de equipamentos e serviços sociais e comunitários para dinamizar a vida social rural.

O Objetivo deste relato foi descrever as estratégias na EFAORI da Juventude como articuladora da participação dos jovens nos processos formativos de Educação no Campo em base agroecológica e na definição das políticas públicas prioritárias aos Jovens Rurais.

\section{RELATO DA EXPERIÊNCIA}

A estratégia utilizada foi a realização entre os anos de 2017 e 2018, na EFAORI Escola Família Agrícola de Orizona, uma série de ações. Estas ações foram planejadas em parceria entre o Colegiado Territorial da Estrada de Ferro, Núcleo de Extensão em Desenvolvimento Territorial (NEDET), Universidade Federal de Goiás, EMATER-GO, Instituto Federal Goiás, Escola Família Agrícola de Orizona, União Nacional das Escolas Famílias Agrícola do Brasil (UNEFAB), organizações governamentais e da sociedade civil dos municípios que integram o Território e Comissão Organizadora Estadual (COE). 0 tema geral desenvolvido foi "Identidade, Cultura e Meios de Produção no Território da Estrada de Ferro". 0 temário territorial foi subsidiado pelos textos de orientação fornecidos pelo Centro Vocacional Tecnológico (CVT) Apinajé, com textos preparados pelos facilitadores que permearam naturalmente nas realidades dos territórios.

As ações contaram com jovens dos municípios do Território, matriculados no $2^{\circ}$ e $3^{\circ}$ ano. Esta mobilização possibilitou, a participação da juventude na organização de ações como revisão teórica sobre a utilização do adubo verde, momento em que também foi feito o esboço do croqui para a implantação do experimento. Em aulas práticas, foi abordada a necessidades da análise do solo, isso permitiu que os alunos obtivessem o primeiro contato com os equipamentos (trado7, penetrômetro8), para a amostragem do solo (0-20 e 20-40), foram identificadas e levadas para o laboratório da UFG. Assim, analisamos com o penetrômetro o grau de compactação do solo. Foram plantadas na área de experimentação da escola, as culturas milheto, crotalária juncea, crotalária anagyroides (planta leguminosa) feijão guandú, feijão guandu anão e feijão de porco. Periodicamente realizaram-se as avaliações das plantas que nasceram, foi realizada medida do diâmetro, altura e número de folhas, contudo, nem todos os blocos germinaram devido à inviabilidade das sementes constatados a partir do teste de germinação que foi realizado posteriormente a não germinação do bloco sendo necessário o replantio de novas sementes.

\footnotetext{
7 Trado: é um instrumento de aço de grande espessura em forma de espiral, que possui a extremidade inferior pontiaguda. Ao girar, o trado consegue perfurar madeira e terra, entre outras coisas.
}

8 Penetrômetro: instrumento que mede a penetrabilidade, a consistência, a firmeza de um material (p.ex. terra, asfalto, graxa) pela profundidade a que nele penetra uma agulha normalizada em condições sob controle. 
O projeto realizou a entrega de 1200 mudas na data 21/09/2018 para a implantação do corredor agroecológico, com a finalidade de fazer a primeira exposição agroecológica da escola familiar agrícola de Orizona (EXPO-EFA). São realizadas acompanhamento quinzenais das atividades.

\section{RESULTADOS E DISCUSSÕES}

O trabalho de pesquisa-ação foi desenvolvido junto aos jovens, de forma participativa, através da: pesquisa nos núcleos de produção, com os temas propostos, gerando conhecimentos e troca de experiência entre pesquisadores, agricultores e outros atores, de forma que se possa trabalhar a pesquisa e o acesso a esses conhecimentos. A fim de propiciar produção de alimento com emprego de insumos alternativos (composto, rochagem, biofertilizante, etc.) contribuírem para elaboração de um modelo de segurança alimentar das áreas de agricultura familiar, dessa forma, foram montadas áreas experimentais na EFAORI. Os trabalhos envolvendo segurança alimentar foram discutidos através da produção de Alimentos integrada com a produção de plantas medicinais e condimentares. Os policultivos foram discutidos empregando-se o sistema de agrofloresta, através da implantação de um corredor agroecológico.

Figura 1: Coleta de amostras de solo com o uso do trado.

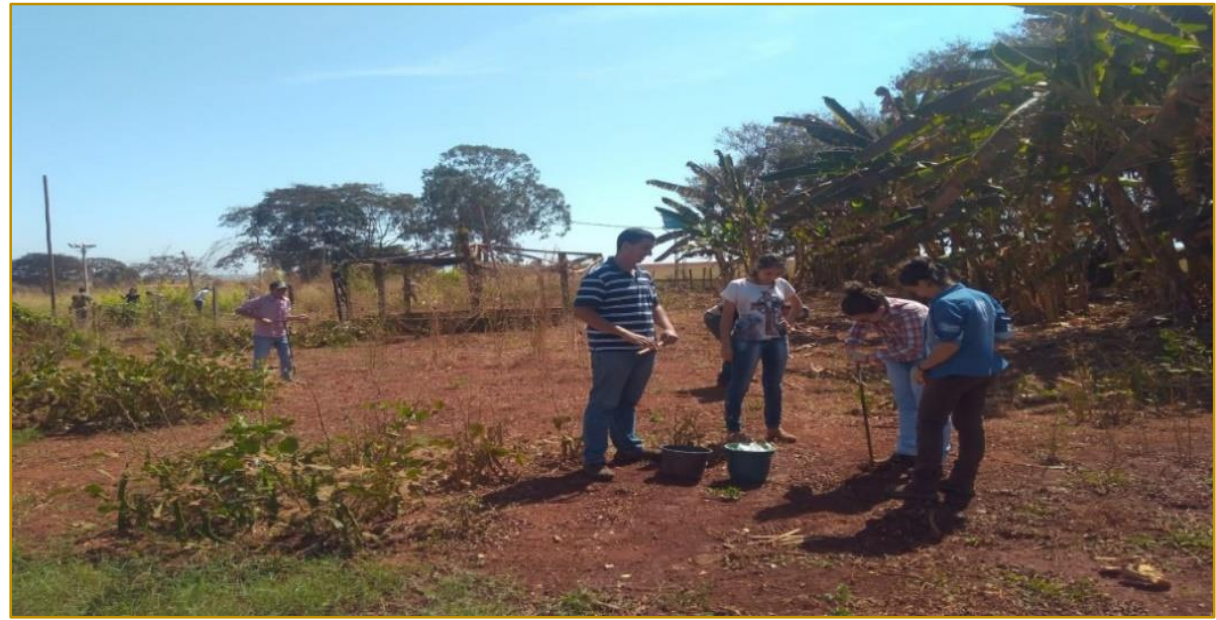

Figura 2: Implantação do experimento com os alunos.

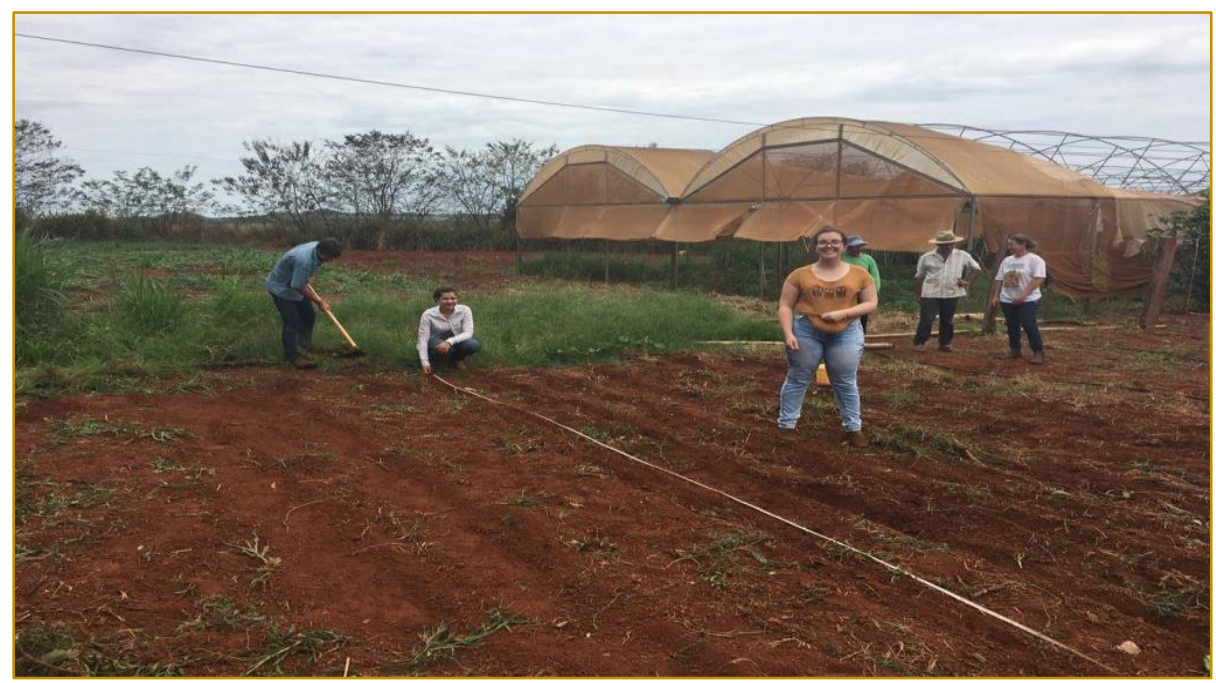


Figura 3: Experimento em desenvolvimento na EFa.

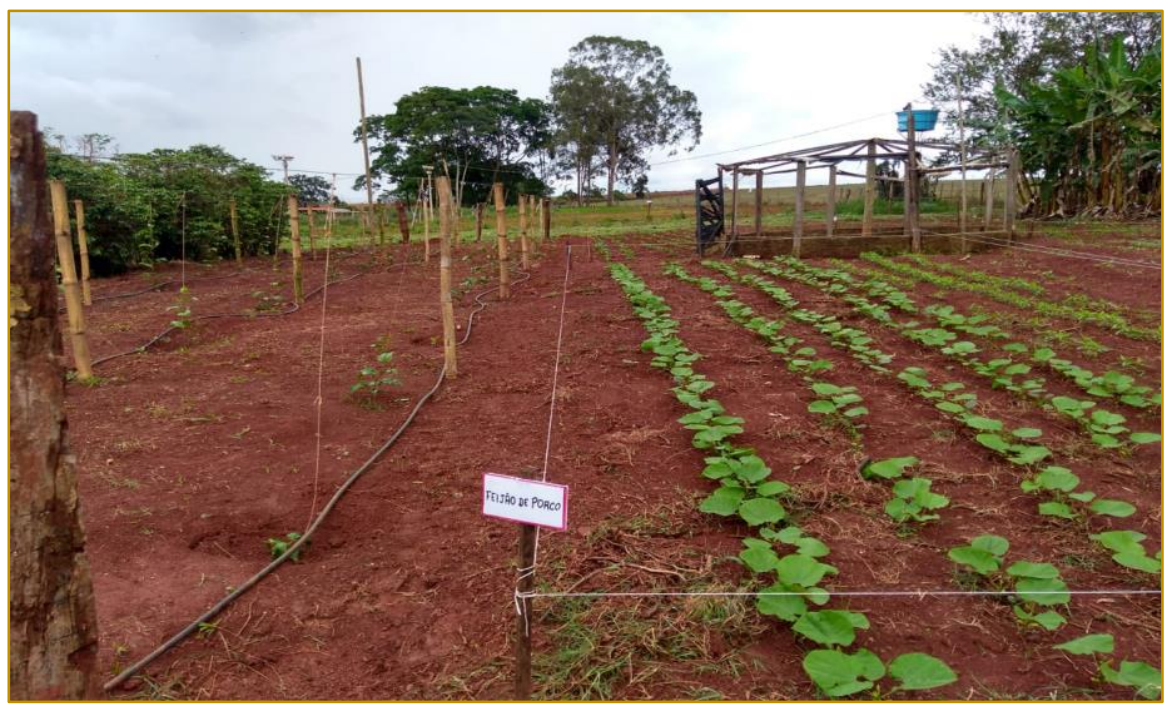

0 redesenho da escola de forma participativa proporcionou aumento de sua autonomia, autoestima, gerando renda a partir de processos de produção agroecológicos, com garantia de credibilidade. As principais práticas agroecológicas adotadas são apresentadas no Quadro1.

Quadro 1. Práticas Agroecológicas difundidas e adotadas em quase todas as unidades

Produtivas trabalhadas e seus impactos.

\begin{tabular}{|c|l|}
\hline \multicolumn{1}{|c|}{ Prática } & \multicolumn{1}{|c|}{ Impactos } \\
\hline Rochagem & Renovação do solo com o uso de silicatos (Kamafugito) fontes de K \\
\hline Adubação verde & $\begin{array}{l}\text { A economia com fertilizantes nitrogenados, grande rendimento por área, sistema } \\
\text { radicular profundo, } \\
\text { descompactar o solo, simbiose com bactérias fixadoras de nitrogênio. }\end{array}$ \\
\hline Rotação de culturas & $\begin{array}{l}\text { Melhoria das condiçães físicas, químicas e biológicas do solo, controle de plantas } \\
\text { daninhas, bem como ao de doenças e pragas, reposição de restos orgânicos, proteção } \\
\text { do solo contra a ação dos agentes climáticos; fixação de nitrogênio com sistema } \\
\text { radicular profundo ou abundante. }\end{array}$ \\
\hline Cobertura morta & $\begin{array}{l}\text { Segurar a umidade do solo e diminuir a temperatura do mesmo; controle da } \\
\text { infestação de plantas daninhas. }\end{array}$ \\
\hline Uso de extratos de plantas & $\begin{array}{l}\text { Controle de insetos-pragas e patógenos causadores de doenças; } \\
\text { Menor impacto nos inimigos naturais }\end{array}$ \\
\hline Agrofloresta & Sistema de policultivos em formato esferoidal para as UDs do Assentamento Canudos. \\
\hline & \multicolumn{1}{|c|}{ Fonte: Elaborado pelo autor. } \\
\hline
\end{tabular}

Os ganhos obtidos no curto e médio prazo foram a ampliação da autonomia e da autoestima não só dos jovens, mas também de toda unidade familiar, por meio do resgate cultural dos conhecimentos tradicionais; conservação ambiental; produção limpa e diversificada; melhor utilização dos recursos naturais; melhor qualidade dos produtos ofertados a sociedade.

Neste sentido, o desenvolvimento de pesquisas e o apoio técnico são importantes para elaboração de estratégias de manejo que aumentem a qualidade do produto e possibilitem a produção de alimentos orgânicos em áreas que receberam por muitos anos fertilizantes químicos e pesticidas.

\section{CONSIDERAÇÕES FINAIS}

O trabalho contribui para elaboração de um modelo de segurança alimentar das unidades familiares camponesas nas áreas experimentais na EFAORI, visando o uso correto do solo, como também a recuperação de solos degradados. 


\section{AGRADECIMENTOS:}

Agradecemos de modo especial ao CNPq pelo financiamento do projeto e concessão de bolsas, e a Escola Família Agrícola de Orizona por permitir o uso de suas áreas para as oficinas e para experimentação.

\section{REFERÊNCIAS}

[1] Stropasolas, Valmir Luiz. Juventude Rural: uma categoria social em construção. In: - XII Congresso Brasileiro de Sociologia. 2009 


\section{Bapítulo 17}

EDUCAÇÃO AMBIENTAL EM CONJUNTO COM PRÁTICAS DE RECUPERAÇÃO DE NASCENTE EM UMA COMUNIDADE RURAL DE IRITUIA - PA

\section{Karolainy Souza Gomes}

Krishna de Nazaré Santos de Oliveira

Maria do Socorro Pires Souza

Raimundo Marly Carvalho de Farias Neto

Tiago Farias Peniche

Resumo: Sabe-se que a água é essencial à vida, por isso é considerada a maior riqueza existente no planeta. Para que se possa usufruir desse bem, é necessário sensibilizar toda a sociedade sobre sua importância e preservação em quantidade e qualidade. Por isso é importante esclarecer que a água de qualidade é um recurso finito, ou seja, a água doce com características para uso e consumo está ficando cada vez mais escassa. Sua escassez pode ser decorrente de interferências naturais e da ação do homem. Nas propriedades rurais as interferências podem estar relacionadas diretamente a algumas atividades agrícolas e de criação de animais, como, por exemplo, a retirada da vegetação nativa, a aração, e outras práticas culturais que movimentam e expõem o solo. Diante do que fora supracitado, pode-se entender a importância das propriedades rurais na produção de água de qualidade. Desta forma, este trabalho objetivou mobilizar e capacitar a família de um produtor rural sobre a importância da preservação das matas ciliares e nascentes afim de que estes pudessem promover a preservação dos recursos hídricos disponíveis em sua propriedade de forma sustentável. Assim, inicialmente, foi realizada uma palestra dialogada com a família, sobre educação ambiental, o segundo passo foi a retirada dos fatores de degradação, e, por fim, foi providenciado o enriquecimento das margens da nascente com espécies nativas. A recuperação de nascentes se torna demorada e muitas vezes o produtor rural é resistente, porém, na propriedade em questão, todos mostraram-se muito receptivos quanto as informações compartilhadas e empenhados nas atividades propostas.

Palavras-chave: Preservação; Enriquecimento; Meio Ambiente. 


\section{INTRODUCC̃̃O}

A água é o elemento de maior importância na natureza, assim como é essencial à vida, por isso é considerada a maior riqueza existente no planeta, pois ela é componente presente em todos os seres vivos, sendo necessária para manter a biodiversidade, além disso, ela também é usada na agricultura, na pecuária, no abastecimento das indústrias e dentre outros setores (SENAR, 2015). Para que se possa usufruir desse bem tão relevante, é necessário sensibilizar toda a sociedade sobre a importância da preservação da água em quantidade e qualidade.

A maior parte do planeta é coberta por água, mas só uma parcela mínima desse líquido está disponível para consumo, por essa razão se torna pertinente preservar a água disponível e promover ações para proteger as nascentes que disponibilizam esse recurso natural.

A escassez da água pode ser decorrente de interferências naturais e da ação do homem. Essas interferências podem estar relacionadas diretamente a algumas atividades agrícolas e de criação de animais, como, por exemplo, a retirada da vegetação nativa, a aração, a gradagem, e outras práticas culturais que movimentam e expõem o solo. Nem sempre as práticas de controle de erosão são realizadas da forma correta, ocasionando sérios problemas no terreno, como o deslocamento de terra e o soterramento de alguma nascente, além das interferências que provocam a diminuição da vazão das nascentes, existem também as intervenções que tornam as águas impróprias para uso e consumo. A poluição das águas pode ocorrer em todos os lugares: córregos, rios, lagos, reservatórios e, inclusive, no lençol freático (SENAR, 2015).

Diante do que fora supracitado, pode-se entender a importância das propriedades rurais na produção de água de qualidade, essa importância está no fato de que a propriedade rural é a produtora das águas que a floram pelas nascentes. Se as nascentes forem protegidas contra as interferências do homem e naturais, esse esforço resultará um aumento da quantidade de água com boa qualidade para consumo (ALVES, CARRARA \& JUNIOR, 2015).

Desta forma, o presente trabalho objetivou mobilizar e capacitar a família de um produtor rural sobre a importância da preservação das matas ciliares e nascentes, afim de que estes pudessem promover a preservação dos recursos hídricos disponíveis em sua propriedade de forma sustentável e múltipla.

\section{METODOLOGIA}

O projeto foi aplicado junto à família do Sr. Raimundo Edilson de Sousa, em sua propriedade, localizada na comunidade Hebron, município de Irituia - PA. De acordo com Köppen e Geiger, o clima dessa região é classificado como Am, onde só existe uma curta época seca e não é muito eficaz, enquanto que na maioria dos meses do ano existe uma pluviosidade significativa, com média anual de $2268 \mathrm{~mm}$. 0 público alvo são os membros da família do Sr. Raimundo Edilson, como esposa, filhos noras e netos, que têm como base econômica a agricultura, cultivando a citricultura (Citrus sp), a pimenta do reino (Piper nigrum) e a criação de gado, estando enquadrados na agricultura familiar.

O trabalho foi realizado em etapas, sendo elas: Capacitação do público alvo sobre o tema abordado; eliminação de fatores de degradação; e introdução de espécies nativas na margem da nascente.

Inicialmente, foi realizado uma palestra dialogada com a família, sobre educação ambiental, mais especificamente sobre a água, ressaltado a importância da preservação das nascentes, utilizando recursos áudio visuais como auxílio. Ao final da palestra aplicou-se um questionário estruturado com todos os membros da família que estavam presentes, com o intuito de avaliar seus conhecimentos sobre o tema.

O segundo passo foi a execução de ações que possibilitassem o restabelecimento do processo ecológico, através da retirada dos fatores de degradação, presença de animais domésticos, espécie invasoras, erosão, resíduos de vegetação, bem como atividades agrícolas e de criação de animais próximos à nascente, evitando que a área volte ao estado degradado.

Por fim, foi providenciado o enriquecimento das margens da nascente com espécies nativas, auxiliando no processo sucessional. Essas ações foram executadas, de forma integrada, pela família, com orientação e supervisão da equipe.

As espécies utilizadas foram: Açaí (Euterpe oleracea Mart.), buriti (Mauritia flexuosa), andiroba (Carapa guianensis), cacau (Theobroma cacao), banana (Musa sp.) e copaíba (Copaifera langsdorffii), que possibilitam maior retenção de água e apresentam interesse econômico para a região. 


\section{RESULTADOS}

Dos nove entrevistados, um não informou a idade, três possuem idade entre 15 a 25 anos, três possuem idade entre 26 a 40 anos e dois possuem idade acima de 41 anos. A partir das respostas obtidas através do questionário chegou-se aos seguintes resultados apresentados na Tabela 1.

Tabela 1 - Informações dos participantes do projeto

\begin{tabular}{|c|c|c|c|}
\hline \multirow{2}{*}{ Faixa Etária } & \multicolumn{4}{c|}{ Já possuía conhecimento a respeito do tema? } \\
\hline $15-25$ & 2 & 1 & ONDE \\
\hline $26-40$ & 1 & 2 & Televisão \\
\hline Acima de 41 & - & 2 & Televisão \\
\hline Não informado & - & 1 & Televisão \\
\hline \multicolumn{4}{r}{ Fonte: Os autores. } \\
\hline
\end{tabular}

Do total dos entrevistados, três ainda não haviam conhecimentos sobre o tema, e os que tinham conhecimento, os adquiriram através da televisão, considerada um meio de comunicação muito eficiente para a transmissão de conhecimentos.

Desta forma, observou-se a necessidade da realização de uma palestra de capacitação abordando sobre utilização, conservação e preservação dos recursos naturais (Figura 01), além disso, 100\% dos entrevistados não realizavam nenhum manejo ou atividade que visasse a preservação dos recursos hídricos de sua propriedade, tornando-se indispensável a realização de mutirões para fazer a intervenção.

Figura 01. Apresentação do tema à família.

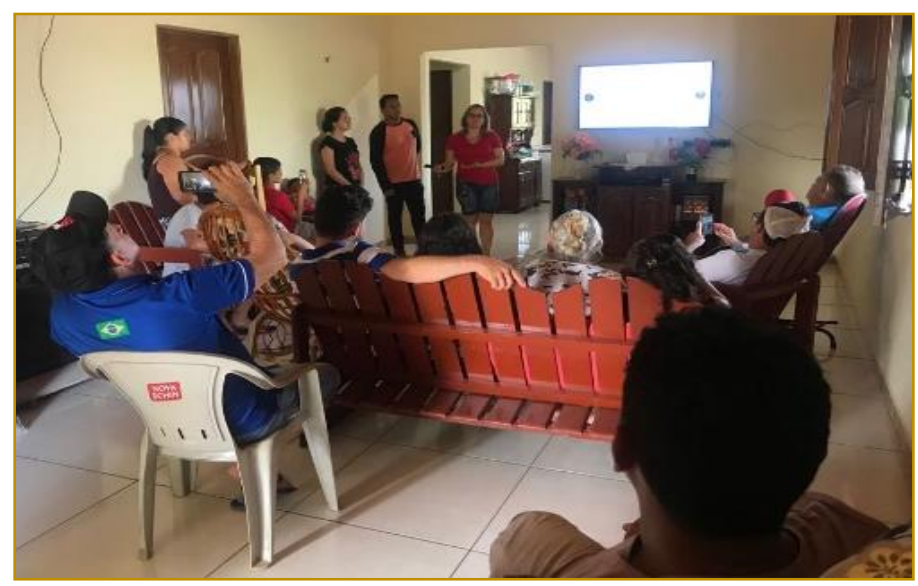

Fonte: os autores.

A primeira etapa do mutirão contou com o apoio da família, principalmente das crianças, para a realização da retirada de fatores de degradação, como folhas e espécies invasoras possibilitando, assim, o aumento da vazão (Figura 02 e 03). Também foi realizada a proteção dos olheiros para que não houvesse o desentupimento dos mesmos. 
Figura 02. Limpeza da nascente.

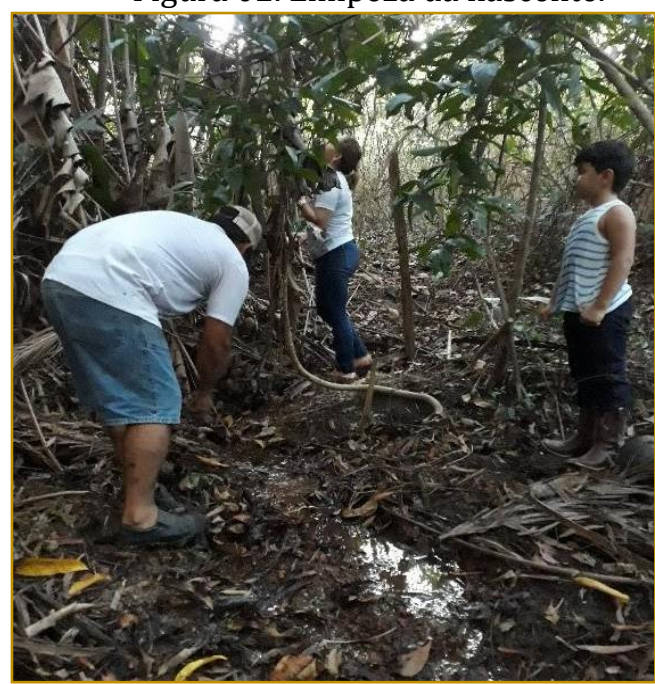

Fonte: Os autores.
Figura 03. Proteção dos olheiros.

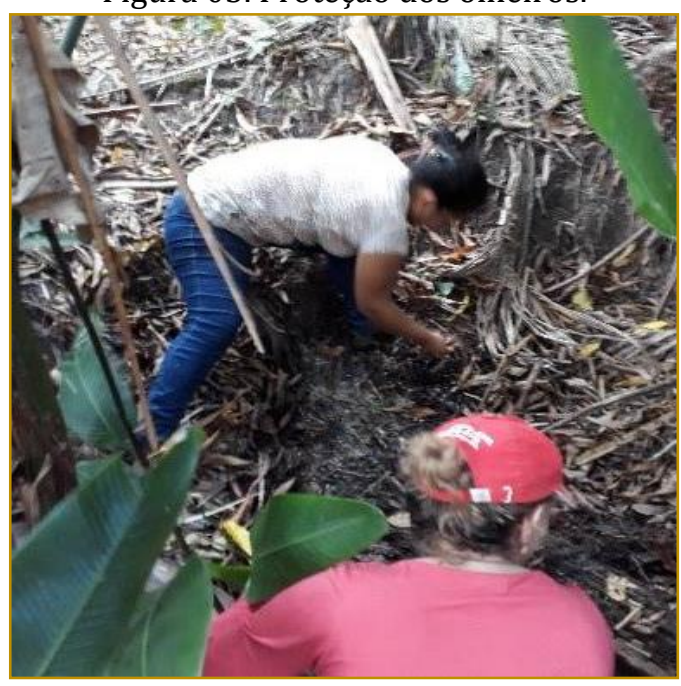

Fonte: Os autores.

A participação da família na segunda etapa do mutirão, possibilitou o enriquecimento da área com espécies de diferentes funções ecológicas encontradas em encostas de igarapé da região, uma vez que a nascente contava com a proteção de uma pequena área de vegetação nativa em estágio de regeneração. Dentre as espécies plantadas destacamos o açaí, cacau, cupuaçu e andiroba (Figura 04).

Figura 04. Enriquecimento de espécies na área.

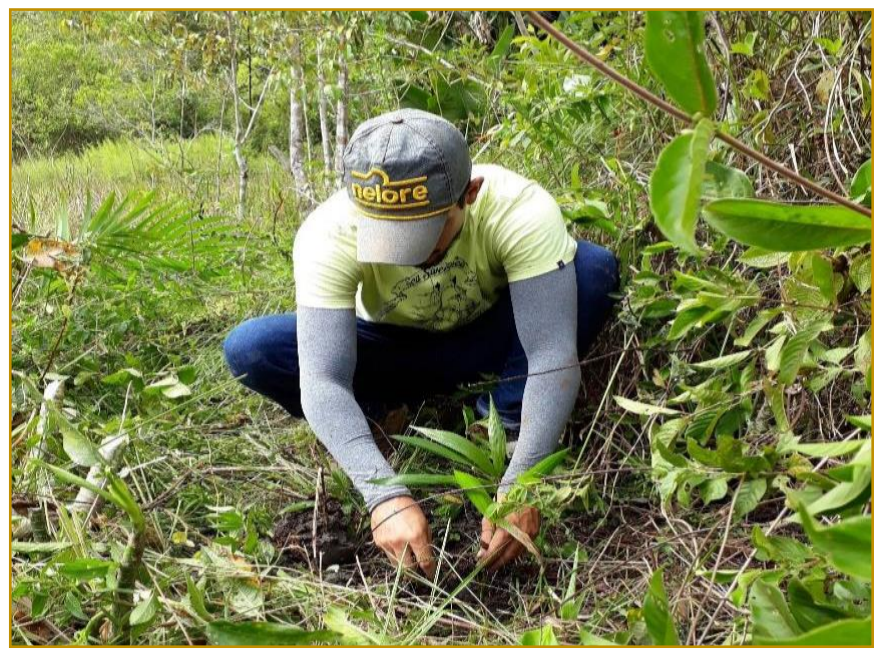

Fonte: Os autores.

\section{CONCLUSÕES}

A recuperação de nascentes se torna demorada e onerosa, e muitas vezes o produtor rural é muito resistente quando se fala em investimento dessa esfera, porém, na propriedade em questão, todos se mostraram muito receptivos quanto às informações compartilhadas e empenhados nas atividades propostas, facilitando assim as ações de recuperação das nascentes visando a sustentabilidade. 


\section{REFERÊNCIAS}

[1] Alves, A. B.; Carrara, D. K.; Júnior, J. M. S. Curso Proteção de Nascentes - SENAR. Brasília - DF, 2015.

[2] Baggio, A. J.; Carpanezzi, A. A.; Felizari, R.S.; Ruffato, A.; Recuperação e proteção de nascentes em propriedades rurais de Machadinho, RS. Empresa Brasileira de Pesquisa Agroperuária. Embrapa Florestas. Brasília, DF. 2013.

[3] Calheiros, R. de Oliveira et al. Preservação e Recuperação das Nascentes (de água e de vida). Comitê das Bacias Hidrográficas dos Rios Piracicaba, Capivarí e Jundiaí. Piracicaba, SP. 2004.

[4] Lakatos, E. M; Marconi, M. A. Fundamentos de Metodologia Científica. 6. ed. São Paulo: Atlas, 2007.

[5] Pinto, L. V. A.; Botelho, S. A.; Davide, A. C.; Ferreira, E. Estudos das nascentes da bacia hidrográfica do Ribeirão Santa Cruz, Lavras, MG. Scientia Forestalis, Piracicaba, n. 65, p. 197-206, 2004.

[6] Senar. Programa Campo Sustentável: Curso de Proteção de Nascentes. Brasília, DF. 2015 


\section{Bapítulo 18}

VISITA TÉCNICA: À AGRICULTURA FAMILIAR DE BASES AGROECOLÓGICAS NO CERRADO SUL-MATO GROSSENSE

\section{Maria Juanna Marques de Amurim Santana}

Franciele Nogueira Paz

Mariele Ramona Torgeski

Tabata Alves Correa

Zefa Valdivina Pereira.

Resumo: As visitas técnicas têm por característica desenvolver aprendizados fora do ambiente universitário, interferindo assim diretamente no pensar e no agir dos acadêmicos. Guiado por estes propósitos, o grupo PET Ciências Biológicas realizou no ano de 2017 uma visita técnica ao assentamento Lagoa Grande no distrito de Itahum, município de Dourados - MS, com o intuito de promover a interação entre os membros e possibilitar a construção de conhecimento dos mesmos acerca do tema: Agricultura familiar gerida por uma economia solidária num modelo produtivo agroecológico onde ocorre a cooperação econômica e a autogestão dos recursos adquiridos entre os participantes do grupo. No ano em questão se comemorava os 10 anos que o projeto "Cerrado em pé" fora implantado pela tutora do grupo PET Ciências Biológicas, que teve como intuito orientar a comunidade do assentamento a trabalhar de forma sustentável, demonstrando que é possível que a agricultura familiar faça o uso sustentável e ecológico do cerrado sul mato-grossense e ainda obter lucros para o sustento dessas famílias, não tendo a necessidade de transformar o cerrado em pastagem como fazem os latifúndios, que convertem grandes extensões de vegetação nativa em pastagem e monocultura na região centro-oeste, contribuindo para que o cerrado se tornasse o bioma mais ameaçado de extinção do país.

Palavras-chave: Troca de saberes, assentamento, ciência cidadã, conservação, restauração, visita técnica. 


\section{CONTEXTO}

A universidade se desenvolve através da produção de novos saberes e disseminação dos mesmos, dentro deste contexto a necessidade a realização de visitas técnicas visa vincular a teoria à prática, interferindo diretamente no pensar e no agir dos universitários. Pois o conhecimento se constitui na relação do homem com o mundo, relações essas que devem ser críticas para que ocorra a transformação. (Freire, 2006).

Dentre as atividades que podem ser trabalhadas no universo do curso de Ciências Biológicas estão a agricultura familiar, a economia solidária e a agroecologia, que podem ser utilizadas como uma forma da construção social do futuro, (Freire, 2006) uma vez que a agricultura familiar produz os recursos de forma mais eficiente, onde mesmo detendo proporções menores de terra e tendo acesso restrito a financiamentos, produzem e empregam mais do que os patronais. (Buainain, 2003).

O Programa de Educação Tutorial - PET do Curso Ciências Biológicas tem por objetivo assegurar o princípio da indissociabilidade das atividades de Ensino, Pesquisa e Extensão. O contato com a realidade por meio, por exemplo, de visitas técnicas, instiga novos temas de pesquisa, o espírito crítico e fomenta debates e discussões que contribuem para o ensino de Ciências Biológicas. As atividades desempenhadas pelo PET Ciências Biológicas são instrumentos de transformação social que favorecem o conhecimento, a formação de novos valores e atitudes ambientalmente corretas através de práticas pedagógicas metodológicas.

Assim, a visita técnica feita pelos estudantes do grupo PET Ciências Biológicas ao assentamento Lagoa Grande teve como objetivo compreender as bases da agricultura familiar, economia solidária e a agroecologia, além de proporcionar um momento de interação entre os membros do grupo PET.

\section{DESCRIÇÃO DA EXPERIÊNCIA}

0 assentamento rural Lagoa Grande é localizado no distrito de Itahum, município de Dourados, MS, entre as coordenadas S $21^{\circ} 59^{\prime} 41,8$ e W 55 $19^{\prime} 24,9$, compreendendo uma área de 4.111 hectares, às margens da rodovia Dourados/Itahum, composto por 151 lotes e localizado em uma microrregião pertencente ao bioma Cerrado.

No ano de 2007 a Universidade Federal da Grande Dourados - UFGD iniciou um trabalho com a comunidade do assentamento para promover a conservação e uso sustentável da biodiversidade do Cerrado, promover a agricultura familiar, a economia solidária e a agroecologia. O projeto "Cerrado em pé" foi implantado com o intuito de orientar a comunidade do assentamento a trabalhar de forma a aliar a produção de alimentos, com a conservação do bioma cerrado e a geração de renda por meio deste, de modo a tornar o assentamento mais sustentável e envolvido com a conservação e recuperação do Cerrado e suas nascentes.

As famílias envolvidas no projeto produzem uma variedade de produtos que tem como matéria prima recursos extraídos de forma sustentável do Cerrado, sendo eles comercializados em feiras na cidade de Dourados e região, além da comercialização na Universidade Federal da Grande Dourados.

Com a visita aproveitou-se a oportunidade para mostrar aos novos integrantes o que é a extensão universitária. Tendo em vista que muitos não sabiam do se tratava e qual era sua essência, portanto foi lhes apresentado o projeto desenvolvido com as famílias do Lagoa Grande, intitulado "Cerrado em Pé” um exemplo prático para melhor entendimento sobre o que é a extensão universitária.

Ao chegarmos ao assentado fomos recepcionados pela proprietária de um dos lotes, a dona Luciana, que mora ali com sua família e participa do projeto. Fomos recebidos com uma mesa farta de alimentos para o café da manhã, onde havia: doces, bolachinhas, pães, queijos, bolos, chá, café e outros, todos eles preparados pelo grupo do assentamento. Muitos dos alimentos postos à mesa fazia parte dos produtos feitos e comercializados pelo grupo por meio do projeto.

Durante o café da manhã dona Luciana foi convidada pela coordenadora do projeto, a então tutora do grupo PET, a contar um pouco sobre sua história de vida e o desenvolvimento do assentamento. Contounos como foi sua luta, as dificuldades e a conquista do lote no qual residem. Também como sua vida sempre foi marcada pelo campo, onde seus pais já faziam uso da terra para sustento e como isso fez ela seguir esse caminho, porém fez questão de destacar a importância que o projeto "Cerrado em Pé" teve em suas vidas, tendo em vista que o uso inicialmente planejado em seu lote era pasto, e que necessitaria, portanto da derrubada do cerrado. 
"A nossa ideia... a gente pensava assim como um grande produtor... um grande produtor de leite... por que aqui no assentamento a maioria das famílias sobrevive do leite, então é conhecido como a bacia leiteira". (Luciana Pogliesi Fernandes).

Nesse momento ela reforça dizendo que essa visão do uso da terra a impossibilitava de ver valor do cerrado em pé e conservado, acreditava se então que o mais rentável era o cerrado no chão, que dava espaço ao pasto ou plantio, algo que aprendeu durante sua vida, mas que com a chegada do projeto tudo mudou, passaram a enxergar o cerrado de outra maneira, onde o cerrado conservado poderia oferecer uma fonte de renda sustentável para as famílias, sendo hoje, uma das suas principais fontes de renda o manejo sustentável do cerrado, transformando suas riquezas em produtos agroecológicos, onde as mulheres comercializam em diversos locais, como a Universidade Federal da Grande Dourados.

Venho destacar aqui, a emoção com que a dona Luciana nós contou sua história, principalmente quando contou o quanto o cerrado significa hoje para ela e sua família, durante sua fala de agradecimento a coordenadora no projeto, agradeceu também pela iniciativa da mesma.

Posteriormente, fomos conhecer o lote de outra família, este que apresenta um grande fragmento do cerrado, sendo ele marcado por queimadas intencionais anteriormente a chegada do projeto. A família residente contou um pouco da sua história, sobre a chegada ao lote e a sua relação com o Cerrado, que da mesma forma da situação anterior, não viam no cerrado uma fonte importante de renda.

Quando eu cheguei aqui em 2002, a minha tendência aqui, era que tudo que tinha da natureza... tinha que derrubar tudo e queimar. Então agora de uns 8 anos pra cá, a ideia da gente, já, é totalmente diferente... Preservar o cerrado, cultivar o que tem da natureza, e de dentro do cerrado a gente tirar o lucro que a própria natureza cede pra gente. (Adonias Joaquim Martins).

Ao terminar sua história o dono do lote nos levou para conhecer sua propriedade e o fragmento de Cerrado que hoje se encontra restaurado após o fim das queimadas. Fizemos uma boa caminhada dentro do fragmento e a todo o momento éramos apresentados a alguma espécie nativa do cerrado com algum tipo de uso, medicinal e ou alimentício. Durante a caminhada esbarramos com um tamanduá bandeira fêmea, que estava com filhote, foi um momento único para todos, onde muitos se depararam pela primeira vez com o animal. Ao voltarmos à residência nos deliciamos com o mel no favo, um dos produtos comercializados pela família, são eles produtores de mel orgânico, onde criam suas abelhas em meio ao cerrado.

Com o término da nossa manhã, fomos almoçar na casa da dona Luciana, e posteriormente fomos conhecer um pouco do seu lote. Quando voltamos para a casa foi o momento de comemorar com o grande bolo os aniversários do mês, servindo também como momento de confraternização entre os petianos e boas vindas aos novos integrantes.

No fim da tarde, após as atividades a tutora do grupo PET propôs que sentássemos em círculo para conversarmos sobre o dia que tivemos, as experiências que foram trocadas e os conhecimentos adquiridos em relação ao Cerrado, economia solidária, agroecologia e principalmente sobre a agricultura familiar, de forma sustentável que gera renda para essas famílias, tudo isso através de uma visita técnica ao assentamento Lagoa Grande.

\section{RESULTADOS}

0 meio ambiente vem sofrendo com intensas ações antrópicas, devido principalmente ao crescimento populacional e à expansão da agricultura monocultora mecanizada. 0 intenso desmatamento para a conversão dessas terras, sobretudo para a agricultura e pastagem, vem transformando grandes florestas nativas em pequenos fragmentos florestais, acarretando na diminuição da biodiversidade, atingindo a fauna e flora, realidade essa do bioma Cerrado, o que faz dele hoje um dos biomas mais ameaçados de extinção do país.

Diante deste cenário, na tentativa de assegurar a sustentabilidade no uso da biodiversidade deste bioma e minimizar a ocorrência de crimes e danos ambientais, têm surgido projetos voltados principalmente ao pequenos produtores, que visam valorização e utilização de recursos naturais como forma de geração de renda conciliada à conservação do bioma.

Existem diversos fatores socioeconômicos e demográficos relacionados às problemáticas dos assentamentos rurais, como produtividade do lote, a renda, a escolaridade, capacitação técnica, a 
estrutura familiar e outros. Entender como esses fatores interferem no desenvolvimento destes locais é de suma importância para criar estratégias de subsistência para a permanência nos seus lotes.

O uso da prática da agricultura de bases agroecológicas pelas famílias do assentamento Lagoa Grande possibilita a superação, a melhoria de vida, a permanência no campo, a contribuição com a produção de alimentos sustentáveis para a subsistência e comercialização, contribuindo para a geração de renda, ao passo em que se procura a preservação e a conservação do bioma Cerrado.

Por meio do Projeto desenvolvido pela universidade o grupo deu início a produção de doces e licores à bases de frutos do Cerrado e outros produtos. Toda a matéria prima para a produção de tais produtos é provenientes de fragmentos florestais do bioma presente no lote ou em lotes vizinhos. A comercialização é realizada por intermédio da economia solidária no campus da UFGD e em feiras na cidade de Dourados.

Através da visita ao assentamento e das conversas com alguns dos moradores foi possível conhecer as dificuldades e os desafios dessas pessoas na conquista da terra, realidade essa de muitas outras famílias de assentados, assim como as dificuldades na geração de renda, onde muitas vezes enxergam em suas terras poucas possibilidades para a geração de renda, como o caso da dona Luciana, que anteriormente ao projeto, tinham a sua principal fonte de renda a produção de leite.

Essas dificuldades enxergar as várias possibilidades de geração de renda através do que o campo tem a oferecer não é um caso isolado do assentamento em questão, mas de muitos outros, e isso se deve em grande parte pela falta de conhecimentos dessas pessoas, que muitas vezes estão condicionadas a ver apenas na agricultura "moderna" que faz uso de grandes pedaços de terras e insumos químicos, e na produção de gado as únicas formas de geração de renda no campo, e veem nos pequenos fragmentos florestais muitas vezes presentes em suas terras como algo sem valor ou uma barreira na produção agrícola ou de gado, e não percebem essas áreas florestais como uma alternativa de geração de renda, de forma a aproveitar os recursos naturais que essas áreas têm de oferecer.

Esse era o caso de muitas famílias do assentamento Lago Grande, que após o projeto aumentaram suas fontes de renda fazendo uso do manejo sustentável dos recursos que o Cerrado oferece. Além da possibilidade em se trabalhar a agroecologia, tornando assim a agricultura praticada no assentamento mais sustentável e com menor impacto ao meio ambiente.

Cabe destacar aqui a importância de projetos como este, que visam promover a agricultura familiar e agroecologia, que trabalham com as comunidades as alternativas de geração de renda através do uso sustentável dos recursos florestais e de forma que promova a conservação deste. Com a visita, ficou clara a importância que o projeto teve na mudança de atitude por parte das famílias participantes do projeto e a contribuição que este teve na ampliação das possibilidades de geração de renda, o que ficou visível durante as falas das duas famílias.

Portanto para o grupo PET Ciências Biológicas a visita técnica ao assentamento Lagoa Grande foi de suma importância, pois possibilitou uma formação cidadã, graças aos diálogos e interações entre pessoas e o meio ambiente. 0 uso de visitas técnicas visa proporcionar uma formação tanto profissional quanto pessoal, possibilitando a aquisição de conhecimentos e experiências não acessíveis dentro da universidade, essas experiências possibilitam aos acadêmicos contatos com outras realidades, muitas vezes completamente distantes, contribuindo em muito com a quebra de preconceitos e paradigmas muitas vezes existentes. 
Figura 1. Círculo de diálogos e troca de saberes. Assentamento Lagoa Grande, distrito de Itahum, município de Dourados-MS.

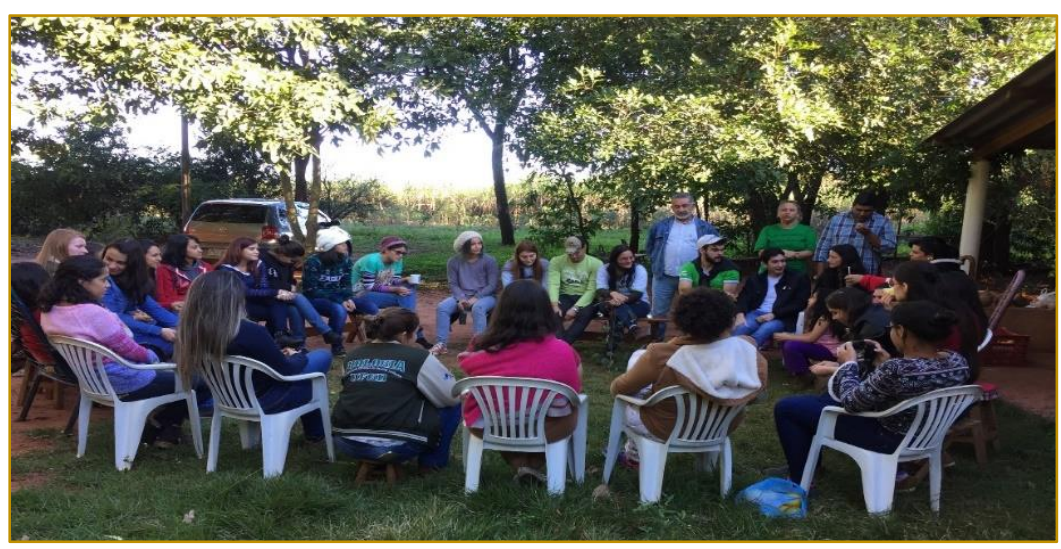

Figura 2. Grupo PET ciências biológicas. Assentamento Lagoa Grande, distrito de Itahum, município de Dourados-MS.

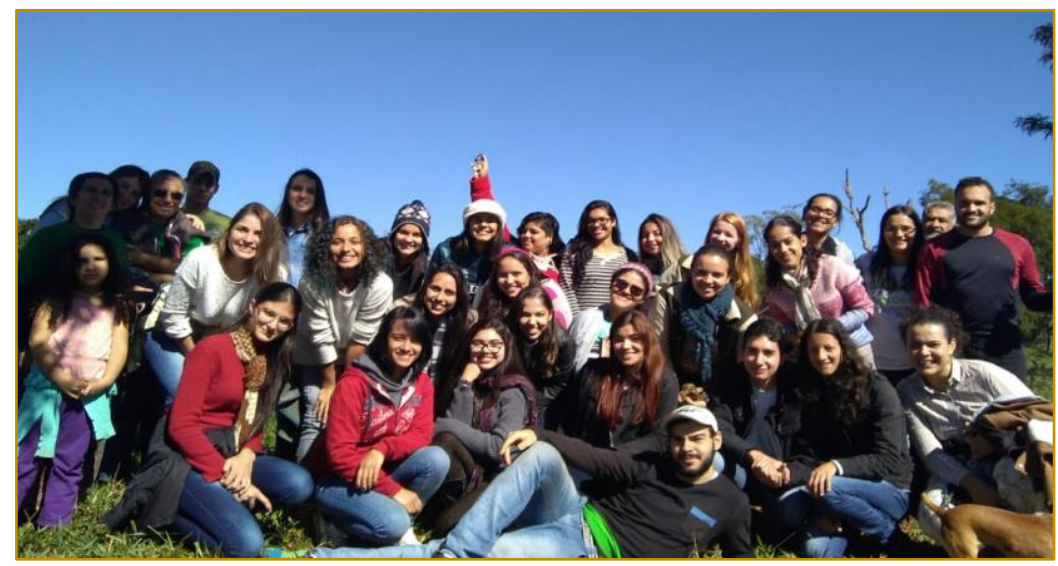

\section{REFERÊNCIAS}

[1] Buainain, Antônio Márcio (et. Al). Agricultura Familiar e o Novo Mundo Rural. Sociologias, Porto Alegre, ano 5, № 10, jul/dez 2003, p. 312-347.

[2] Freire, Paulo. Pedagogia da Autonomia: saberes necessários à prática educativa. 34a edição. São Paulo: Paz e Terra, 2006.

$[3]$ . Conscientização: teoria e prática da libertação. São Paulo: Ed Moraes, 1980 Educação como Prática da Liberdade. 30a Edição. Rio de Janeiro: Paz e Terra. 2007 Educação e Mudança. 9a edição. Rio de Janeiro; Paz e Terra. 1983. Extensão ou Comunicação. 13a Edição. São Paulo: Paz e Terra. 2006. .Pedagogia do Oprimido. 45a Edição. Rio de Janeiro: Paz e Terra. 2005. 


\section{Bapítulo 19}

MOTIVAÇÕES DE PROFESSORES PARA TRABALHAR COM AGROECOLOGIA NA EDUCAÇÃO FORMAL

\section{Diane Ivanise Fiamoncini}

\section{Cláudia Márcia Lyra Pato}

Resumo: Esse estudo investigou as crenças de professores sobre a melhor forma de conduzir a produção de alimentos e suas motivações para ensinar Agroecologia. Foram feitas entrevistas com cinco professores da área de ciências agrárias (3 mulheres; 2 homens) com média de idade de 46,25 anos e pelo menos seis anos de exercício profissional na área. Utilizando como critério similaridades e particularidades nas respostas, destacou-se a crença de que o atual modelo de agricultura está gerando sérios problemas ambientais e de saúde tanto para os agricultores quanto para os consumidores. A Agroecologia foi indicada como solução para estes problemas. Com relação às práticas pedagógicas, os participantes apontaram para a necessidade de atividades interdisciplinares e propostas metodológicas centradas no entorno das escolas. Dentre as dificuldades enfrentadas para lecionar Agroecologia, destacaram grade curricular fechada e conteúdos pré-determinados. Esses resultados apontam para a importância do fortalecimento de práticas pedagógicas adequadas ao contexto das escolas de modo a facilitar o ensino da Agroecologia.

Palavras-chave: crenças; práticas pedagógicas; cursos técnicos e tecnológicos de agroecologia; saúde; meio ambiente. 


\section{INTRODUCC̃̃O}

A formação em ciências agrárias dos professores que lecionam nos cursos técnicos, tecnológicos e superiores em Agroecologia requer especial atenção. Sarandón (2002) já apontava para esta formação como seguidora de um modelo produtivista de altos rendimentos. Esse modelo não responde à totalidade das situações que existem no meio rural, como os casos das comunidades que ocupam áreas marginais e possuem escassos recursos. Mais tarde, Jacob et al. (2009), num estudo sobre a inclusão do enfoque agroecológico nas ciências agrárias, concluíram que a abordagem da agricultura familiar e da agroecologia era difusa. Dessa forma, outros espaços curriculares são necessários para que os futuros profissionais destas ciências possam se tornar aptos a atuar com base em fundamentos agroecológicos. Corroborando estas ideias, Pinto (2014), referindo-se aos professores dos cursos recentes de Agroecologia, afirma que estes professores vivem uma crise paradigmática na prática docente, por não terem tido formação para tal.

Nesse contexto pedagógico são formadas as novas gerações de profissionais na área de produção de alimentos. Desse modo, pode-se transferir crenças e visão sobre a melhor forma de produção, o que pode contribuir para a manutenção de um modelo ou gerar novas perspectivas.

Diante deste quadro e com base no modelo teórico Valores-Crenças-Normas (Stern, Dietz \& Kalof, 1993; Stern, Dietz, Kalof \& Guagnano, 1995; Stern, 2000) esse estudo investigou as crenças dos professores formados em ciências agrárias para lecionar agroecologia. Além disso, buscou-se compreender suas motivações, bem como suas práticas pedagógicas.

\section{MATERIAL E MÉTODOS}

\subsection{PARTICIPANTES}

Cinco professores da área de ciências agrárias de três Instituições Federais de Educação, Ciência e Tecnologia. Desses, 3 mulheres e 2 homens, com média de idade de 46,25 anos, com experiência de no mínimo seis anos de atuação de magistério em Agroecologia. Todos foram voluntários e receberam garantia de sigilo e anonimato.

\subsection{INSTRUMENTO}

Entrevistas individuais foram realizadas e orientadas por um roteiro prévio de perguntas, tais como: há quanto tempo trabalham com Agroecologia, o que os levou a se envolverem com esta área, como são suas práticas pedagógicas, quais motivações os levam a continuar trabalhando com Agroecologia e quais objetivos esperam que sejam alcançados em relação à Agroecologia.

\subsection{PROCEDIMENTOS}

As entrevistas foram feitas presencialmente, no local definido pelos participantes. Os entrevistados foram convidados a participar e se apresentaram voluntariamente. As entrevistas foram gravadas mediante autorização prévia dos participantes, que assinaram um termo de consentimento livre e esclarecido. Posteriormente as gravações foram transcritas e analisadas tendo em vista os objetivos da pesquisa.

\subsection{ANÁLISE DOS DADOS}

Os dados obtidos foram comparados entre si utilizando-se como critério de seleção a similaridade das respostas e particularidades importantes de serem relatadas.

\section{RESULTADOS E DISCUSSÃO}

O tempo de experiência dos professores com Agroecologia é bastante variado, indo de seis até trinta e quatro anos. Essa delimitação de tempo é relativamente difícil, tendo em vista que a percepção dos participantes é de que atuavam com práticas de agroecologia antes da criação formal do curso. Alguns citaram participar dos movimentos de agricultura alternativa da década de 80 . 
Dentre os motivos relatados pelos participantes para se envolverem com Agroecologia destaca-se a crença de que o atual modelo de produção de alimentos gera sérios problemas ambientais e de saúde, tanto para os agricultores quanto para os consumidores. Desse modo, consideram necessário levar informação sobre formas mais sustentáveis e menos nocivas de produção não só para os estudantes, bem como para as comunidades do entorno, sobretudo aos agricultores familiares.

Tomar conhecimento de casos de intoxicação de agricultores e perceber que havia desconhecimento destes sobre o uso correto dos agrotóxicos, assim como o fato de que se tratava de algo nocivo a própria saúde foi um estímulo para que alguns desses professores buscassem outra forma de produção, sem uso de agrotóxicos. Na visão desses professores, era necessário mudar essa realidade, que para eles estava associada à pobreza material, aliada à necessidade forjada do uso de agrotóxicos. Nesse contexto, emergem relatos de envolvimento direto e pessoal com agricultores que adoeceram. E há uma clara percepção de associação direta entre o adoecimento e morte destes agricultores e o uso inadequado de agrotóxicos.

Pode-se ressaltar que as tecnologias propostas nos cursos de agronomia na década de 80 não se adequavam a diferentes realidades. De acordo com Sarandón (2002), o modelo de agricultura à época não correspondia à diversidade de contextos existentes no meio rural. Para ilustrar, um participante relata que o seu curso de agronomia era todo baseado em materiais e exemplos da região Sudeste. Entretanto, ele era originário da região Nordeste e tinha a motivação de ajudar sua família a produzir de forma mais adequada. 0 ensino, na opinião dele, era principalmente agricultura industrial, baseada no tripé do agronegócio: mecanização, biotecnologia e agroquímicos. E esse modelo é inacessível aos agricultores de baixa renda, o que leva à busca de movimentos de agricultura alternativa, emergentes na década de 80 . Pode-se perceber que o envolvimento com formas alternativas de produção agrícola contribui para o consequente envolvimento com a agroecologia. Em alguns casos, converte-se em militância política associada à educação do campo.

Muito embora com a ausência do enfoque agroecológico na grade curricular dos cursos, eventos extracurriculares promovidos no ambiente acadêmico foram apontados como motivadores, despertando o interesse pela agroecologia. Por exemplo, palestras com expoentes da agroecologia, como Ana Maria Primavesi e Ernst Götsch, foram oportunidades para alguns tomarem conhecimento e despertar o interesse pelo tema. A percepção de uma aliança entre sistema de produção e natureza, associada às dimensões sociais e políticas subjacentes, igualmente revelam-se motivadoras para o envolvimento desses participantes com a agroecologia.

Esses resultados revelam que as experiências pessoais foram significativas para sensibilizar esses professores e despertar neles o interesse pela Agroecologia. Destaca-se o aspecto afetivo como fundamental para a motivação deles nessa área, aliando-se aos aspectos cognitivos de conhecimento e informação a respeito de distintas formas de produção.

Desse modo, esses entrevistados revelam a formação de crenças a respeito da Agroecologia. A principal delas é a de que a Agroecologia é a solução para os problemas apontados, como adoecimento dos agricultores, falta de acesso aos meios de produção, degradação do solo e danos ambientais, entre outros. Esta crença é corroborada pela FAO - Organização das Nações Unidas para a Alimentação e a Agricultura, conforme relatório de 2008. Nesse documento, a Agroecologia é apontada como um meio de desenvolvimento agrícola, que além de estar conectada com o direito à alimentação, possui resultados comprovados na concretização desse direito humano para muitos grupos vulnerabilizados em diversos países e ambientes (SCHUTTER, 2012).

Com relação às práticas pedagógicas compatíveis com a concepção de agroecologia, os professores apontaram que há necessidade de se trabalhar de forma interdisciplinar. Entretanto, reconhecem as dificuldades existentes para se conseguir trabalhar em conjunto com professores de outras disciplinas devido à falta de horários de planejamento coletivo, à limitação da grade curricular e à resistência por parte de alguns professores. Esta resistência já era apontada por Sarandón (2002) quando citou a dificuldade dos professores formados no antigo paradigma atuarem de modo diferente por terem medo devido à incerteza de seu papel dentro do novo paradigma.

O trabalho interdisciplinar permanece um desafio e leva os professores a consequente necessidade de desenvolverem propostas metodológicas adequadas ao ensino da agroecologia. Há um consenso entre os participantes de que não se pode enquadrar a Agroecologia em uma grade curricular fechada, com conteúdos programáticos pré-definidos. 
Sarandón (2002) corrobora com essa visão quando afirma que ao se tentar incorporar a Agroecologia no currículo de instituições de ensino, não há muita flexibilidade para incluir novas metodologias, enfoques e conteúdos com agilidade suficiente nos planos de ensino. Essa perspectiva se alinha à importância destacada pelos entrevistados de que é preciso vivenciar a realidade local onde atuam. Por exemplo, todos relataram levar seus alunos para conhecer agricultores e a pensar soluções para problemas vivenciados, como os causados por insetos, dentre outros.

Nessa direção, pode-se compartilhar a experiência utilizada por uma das instituições federais de ensino onde alguns entrevistados atuam, que possui uma disciplina chamada Vivência. Voltada para o desenvolvimento de projetos e atividades práticas, essa disciplina reúne vários professores para juntos coordenarem projetos realizados nas comunidades vizinhas ou mesmo dentro da área do instituto. Um exemplo prático, relatado por um dos entrevistados, foi a construção do Plano de Desenvolvimento de um assentamento próximo ao instituto.

Apesar das dificuldades apontadas e da necessidade de mudanças nas propostas pedagógicas, os entrevistados continuam motivados a trabalhar com Agroecologia. A crença de que não há outro caminho e que a mudança para a agroecologia terá que acontecer em algum momento, diante das práticas insustentáveis da agricultura atual, é seu principal motivador.

De modo geral, os entrevistados consideram que o futuro depende dessa forma de agricultura. Esses professores consideram fundamental que a Agroecologia seja compreendida e tenha maior apoio dos governos federal, estadual e municipal. Esperam que assim sejam gerados alimentos saudáveis para a sociedade, com preço acessível, trazendo a agricultura de volta para a cidade. Por sua vez, percebem a agricultura atual como redutora da biodiversidade, que gera impactos incalculáveis, desejando que seja reduzida, podendo chegar ao fim.

Nesse sentido, para eles, a curto prazo, é importante que se divulgue a agroecologia para as pessoas, informando sobre o que é e o que pretende. Em longo prazo, espera-se ver todos vivendo em equilíbrio e harmonia com saúde tanto nas pessoas quanto no ambiente. Espera-se também a união dos produtores agroecológicos e o estabelecimento de áreas grandes livres de transgênicos e agrotóxicos.

E quanto aos cursos de agroecologia, eles consideram importante que haja um nivelamento continuado de informações sobre o tema. De maneira que novas propostas pedagógicas, com maior flexibilidade de tempo e espaço, possam ser implantadas. E que propiciem aproximações maiores com a comunidade onde estão inseridos, que transformem realidades, pelo menos ao seu redor.

\section{CONCLUSÃO}

Apesar da falta de inclusão do enfoque agroecológico nos cursos de formação inicial dos entrevistados, suas experiências com esse tipo de prática, as relações afetivas com pessoas próximas que atuam dessa forma ou que possuem conhecimento especializado sobre esse assunto foram aspectos importantes que os impulsionaram a investir nessa atuação.

Nesse sentido, considera-se premente a inclusão do enfoque agroecológico nos cursos de formação em ciências agrárias. Desse modo, espera-se contribuir para o engajamento de profissionais preocupados com a produção de alimentos, que considerem distintas realidades e contribuam para a sustentabilidade socioambiental.

A crença de que a agroecologia é o caminho para a resolução dos impactos causados pelo atual modelo de agricultura ressalta seu potencial como maneira de produção mais ecológica e sustentável. Metodologias mais compatíveis com uma educação transformadora são necessárias nos cursos específicos de Agroecologia. De tal modo que o uso de atividades interdisciplinares e de propostas metodológicas centradas na realidade da comunidade escolar e seu entorno possa contribuir para a autonomia e o empoderamento dos estudantes. Consequentemente, propiciará a transformação de suas realidades, suas comunidades e comunidades vizinhas, num efeito multiplicador. Desse modo, a Agroecologia pode contribuir para a melhora na qualidade de vida das famílias e do ambiente do entorno. 


\section{REFERÊNCIAS}

[1] Jacob, L.; Castro, T. P. Sollero, G. C.; Iamamoto, A. T. V. \& Sparovek, G. Agroecologia na Esalq/Usp. Resumos do VII CBA e II Claa. Revista Brasileira de Agroecologia. Vol. 4, n.2, p. 3387-3390, 2009.

[2] Pinto, D. S. de. Identidades e trajetórias de educadores na Agroecologia. 2014. 175f. Dissertação (Mestrado em Educação) - Universidade Federal Rural do Rio de Janeiro, Seropédica-RJ, 2014.

[3] Sarandón, S. J. Incorporando el enfoque agroecológico em las Instituciones de Educación Agrícola Superior: la formación de profesionales para uma agricultura sustentable. Agroecologia e Desenvolvimento Rural Sustentável. Porto Alegre: Vol. 3, n.2, abril/junho, 2002.

[4] Schutter, 0. Agroecologia e o direito humano à alimentação adequada: tradução do relatório de Olivier de Schutter: relator especial da Onu para o direito à alimentação. Brasília: Mds, v. Caderno Sisan 01, Câmara Interministerial de Segurança Alimentar e Nutricional, 2012. Disponível em: <http://bibspi.planejamento.gov.br/bitstream/handle/iditem/165/Caderno\%20SISAN\%2001-2012\%20\%20Agroecologia\%20e\%20o\%20Direito\%20Humano\%20\%C3\%A0\%20Alimenta\%C3\%A7\%C3\%A3o\%20Adequada. pdf?sequence=1>. Acesso em: 19 ago 2017.

[5] Stern, P. C., Dietz, T. \& KALOF, L. Value orientations and environmental concern. Environment and behavior, Vol. 25, p. 322-348, 1993.

[6] Stern, P. C., Dietz, T., Kalof, L. \& Guagnamo, G.A. Values, Beliefs, and Proenvironmental Action: Attitude Formation Toward Emergent Attitude Objects. Journal of Applied Social Psychology, Vol. 25 (18), p. 1611-1636, 1995.

[7] Stern, P.C. Toward a coherent theory of environmentally significant behavior. Journal of Social Issues, 56 (3), p. 407-424, 2000. 


\title{
Bapítulo 20
}

\section{SEMEAR A TERRA E PLANTAR SABERES: O TRABALHO DE UM COLETIVO AGROECOLÓGICO EM AQUIDAUANA-MS}

\author{
Gabriel Loschiavo Cerdeira \\ Sabrina Policarpio Souza Campos \\ Julia Caroline Machado de Araujo \\ Gabriel Aparecido Saldanha \\ Camilo Alejando Bustos Avila
}

Resumo: 0 capitulo a seguir tem por objetivo apresentar as experiências relativas à implementação de espaços agroecológicos no munícipio de Aquidauana no Estado de Mato Grosso do Sul, que são frutos da formação do coletivo de agroecologia dentro da Universidade Federal de Mato Grosso do Sul no campus de Aquidauana (UFMS-CPAq). Dessa forma, esse trabalho traz uma versão revisada e mais profunda do artigo publicado nos anais do evento Agroecol 2018. O coletivo criado e organizado por discentes da instituição busca trabalhar com a agroecologia enquanto: ciência, prática e movimento social. 0 trabalho do coletivo tem fomentando o debate sobre a agroecologia dentro e fora da comunidade acadêmica, possibilitando o planejamento e a construção de espaços agroecológicos de baixo custo no município de Aquidauana. Essas ações têm modificado, ainda que de forma singela, a paisagem da universidade, mas, sobretudo vem transformando as pessoas diretamente envolvidas que modificam seus hábitos e passam estabelecer uma nova forma de relação com o espaço. 0 manejo e a obra do coletivo têm ganhado projeção, impactando um número maior de pessoas, graças ao uso do espaço agroecológico por docentes da universidade para realização de aulas praticas e da parceria estabelecida com uma escola estadual aonde o coletivo também vem desenvolvendo atividades. Sendo assim, essa experiência demonstra o potencial aglutinador e transformador da agroecologia, bem com o papel que grupos autogeridos podem ter na construção de fissuras no status quo, abrindo frestas para construção de novas relações sociais e ambientais.

Palavras-chave: Agroecologia. Autogestão. Coletivo. 


\section{CONTEXTO}

Ao observarmos o mundo ao nosso redor, bem como nos atentarmos aos jornais, filmes e publicações acadêmicas, perceberemos a presença de uma série de problemas sociais e ambientais que afetam diretamente a qualidade de vida da população.

Vivemos atualmente perante um verdadeiro desafio socio-ambiental, uma vez que

A globalização de uma mesma matriz de racionalidade comandada pela lógica econômica em sentido estreito nos conduz inexoravelmente a uma economia que ignora sua inscrição na terra, no ar, na água, no solo, no subsolo, nos ciclos vitais das cadeias alimentares, de carbono, de oxigênio...e, assim, a humanidade toda, embora desigual, está submetida a riscos derivados de ações decididas por alguns e para benefício de alguns (Gonçalves, 2006 b, p.72).

0 resultado de um sistema mundo moderno-colonial onde impera uma racionalidade centrada na economia é a intensificação problemática da crise socioambiental (GONÇALVES, 2006). Crise esta que resulta na degradação ambiental e na exclusão social, sendo resultado da expansão e consolidação do modo de produção capitalista, tendo fortes laços com a forma que o conceito de natureza é definido na sociedade hegemônica atual e seu modo de produção (GONÇALVES, 2006).

Nesse contexto, o espaço rural é transformado devido à expansão das relações do modo de produção capitalista, passando a contar cada vez mais com a presença da mecanização, dos transgênicos, adubos químicos e agrotóxicos. Resultando, no Brasil, na perpetuação de uma estrutura fundiária extremamente concentrada, expulsão da população do campo, perda de autonomia dos produtores rurais, prejuízos à saúde da população e impactos ambientais (IHA, 2017).

Essas transformações no campo se intensificam no Brasil após a década de 1960 em decorrência da proliferação dos ideais e praticas ligados ao paradigma da revolução verde.

Como escreveu Altieri

Na segunda metade do século XX, vários países latino-americanos engajaram-se na intitulada Revolução Verde, um ideário produtivo proposto e implementado nos países mais desenvolvidos após o término da Segunda Guerra Mundial, cuja meta era o aumento da produção e da produtividade das atividades agrícolas, assentando-se para isso no uso intensivo de insumos químicos, das variedades geneticamente melhoradas de alto rendimento, da irrigação e da motomecanização. Políticas públicas nacionais foram criadas, tendo a pesquisa agrícola e a extensão rural - aliadas geralmente ao crédito agrícola subsidiado como os principais instrumentos para a concretização dessas políticas (ALTIERI, 1998, p.7).

Ainda sobre o desenvolvimento da Revolução Verde, é necessário entendermos o impacto geopolítico desse processo, em meio a um mundo marcado pela guerra fria, uma vez que

A Revolução Verde se desenvolveu procurando deslocar o sentido social e político das lutas contra a fome e a miséria, sobretudo após a Revolução Chinesa, Camponesa e Comunista, de 1949. Afinal, a grande marcha camponesa lutando contra a fome brandido bandeiras vermelhas deixara fortes marcas no imaginário. A Revolução Verde, tentou, assim, despolitizar o debate da fome atribuindo-lhe um caráter estritamente técnico. 0 verde dessa revolução reflete o medo do perigo vermelho, como se dizia à época. Há, aqui, com essa expressão Revolução Verde, uma técnica argumentativa própria da política (GONÇALVES, 2006, p226).

A revolução verde é fruto da ciência ocidental, que buscou aumentar a rentabilidade e a produtividade dentro de uma lógica capitalista, entendendo a problemática da fome como uma questão puramente técnica, esvaziando seu conteúdo político. 0 processo de expansão das relações de produção capitalista esta correlacionada à consolidação e predomínio de uma ciência fragmentaria pautada na divisão do trabalho e imposta desde os centros de poder que não reconheceu os conhecimentos das populações tradicionais e indígenas. A ciência permitiu avanços importantes e o desenvolvimento técnico-científico, mas ao mesmo tempo significou a ampliação da marginalização e da concentração de capital, tendo em vista que 
A ciência positivista é incorporada pelo capitalismo como um atributo tanto para garantir como para ampliar diferentes formas de expansão. 0 desenvolvimento técnico-científico não só amplificou a capacidade de acumulação e extração de mais-valia, mas também passou a realizar o papel de instrumento ideológico justificador de uma posição privilegiada na sociedade (IHA, 2017, p. 40).

Sobre o domínio da lógica da Revolução Verde, produtivista e mercantil, o campo passa cada vez mais a operar dentro de uma temporalidade abstrata e uniforme, visando acelerar o processo produtivo submetendo o espaço rural ao tempo da indústria, do capital e do mercado na busca incessante do lucro.

Essa lógica temporal rompe com os ciclos biogeoquímicos dos diferentes biomas, resultado na degradação da fertilidade dos solos, aumentando o uso de adubação química o que elevou a dependência do campo a indústria que produz os insumos sintéticos, que muitas vezes são derivados de recursos não renováveis. Nesse cenário, o produto agrícola passa cada vez mais a ser intermediado pela presença da indústria e do capital financeiro (GONÇALVES, 2006).

Assim, o modelo agricola-agrario hegemônico, pautado na ciência ocidental e no latifúndio, gera um campo marcado pela dependência de insumos externos e do fortalecimento do agronegócio que emprega pouca mão de obra, expulsado o(a) agricultor(a) do espaço rural.

Atendendo as demandas externas, esse modelo agricola-agrario, possui três características fundamentais: a) separar o produtor do consumidor; b) o produto não é consumido pelo produtor e c) o lugar de produção não é o lugar de consumo (GONÇALVES, 2006). 0 agronegócio brasileiro segue esses parâmetros, produzindo toneladas de commodities que não vão atender as necessidades locais, mas sim o desejo de recursos com baixo custo econômico dos países centrais.

Dentro desse contexto, o Brasil passou a ser um dos maiores consumidores de agrotóxicos do mundo, o que resulta em impactos negativos ao ambiente e a saúde humana. 0 uso abusivo de agrotóxico é um grave problema que afeta diretamente a vida dos trabalhadores rurais, uma vez que

No período de 1999 a 2009, tivemos, notificados pelo SINTOX (Sistema Nacional de Informações Tóxico-Farmacológicas - Ministério da Saúde/FIOCRUZ), cerca de 62 mil intoxicações por agrotóxicos de uso agrícola. Isto significa que tivemos por volta de 5600 intoxicações por ano no país, o que equivale a uma média de 15,5 intoxicações diárias, ou uma a cada 90 minutos (Bombardi, 2011, p.6)

O uso do agrotóxico prejudica a saúde da população brasileira, os dados demonstram que no período de 1999-2009, "ocorreram 1876 casos de morte por intoxicação com agrotóxicos registrados pelo SINTOX. Isto significa que foram cerca de 170 mortes por ano" (Bombardi, 2016, p.2). Lembramos que esses dados podem estar subrelatados, pois estas intoxicações aparecem, na maior parte dos casos como outros problemas de saúde (Bombardi, 2016)

No Estado de Mato Grosso do Sul, onde nosso trabalho foi realizado, no período de 2012-2014 foi consumido em média anual 51534 toneladas de agrotóxicos. Esses produtos químicos geram impactos ambientais e causam danos à saúde da população, tendo em vista que no intervalo que compreende 20072014, foram registrados 324 casos de intoxicações por uso agrícola de agrotóxicos (BOMDARDI, 2017).

Em oposição a essa realidade hegemônica que envenena as pessoas e o ambiente, a agroecologia enquanto prática, ciência e movimento social vem ganhando força (CUNHA, 2017, p. 186). A agroecologia busca o estudo e a consolidação de agroecossistemas sustentáveis do ponto de vista ambiental e social. Possibilitando a geração de alimentos saudáveis, com baixo consumo de insumos e fomentando redes de consumo e produção solidaria e justas. 
Lembramos que o conhecimento agroecológico, não se reduz a elaboração de agroecossistemas sustentáveis, mas, sobretudo,

Os debates da agroecologia se aproximam das perspectivas da descolonialização do saber e do poder, que envolvem a luta pela desconstrução dos cenários intensificados no sistema-mundo patriarcal/capitalista/colonial/modernos (Cunha, 2017, p.186).

A partir dessa visão, discentes da UFMS-CPAq, decidiram consolidar um coletivo para o estudo e prática da Agroecologia. O objetivo do coletivo é o aprofundamento teórico, por meio da realização da leitura de textos, palestras, filmes e debates, bem como a realização de mutirões para implementação de um manejo agroecológico dentro da universidade visando a geração de serviços ambientais, alimentos, sementes e um espaço de convivência para os discentes.

Em sua busca por estudar e praticar a agroecologia o coletivo tem buscado dialogar com diferentes saberes, reconhecendo o conhecimento dos povos indígenas e camponeses da região. Dessa forma, o sistema agroflorestal construído na Terra Indigena Cachoeirinha no município de Miranda, MS (ANTONIO; SANT'ANA; MELO, 2016), bem como a agricultura e luta dos assentados do assentamento Indaiá IV, servem de exemplo e inspiração para nossas propostas.

O coletivo de agroecologia também tem favorecido o desenvolvimento da relação entre discentes e os(as) trabalhadores(as) da universidade, sobretudo, com os(as) que atuam na jardinagem do campus. Esse dialogo envolve troca de conhecimentos sobre técnicas de plantio e de cultivares, onde os discentes e trabalhadores se fortalecem.

A atuação e organização do coletivo de agroecologia esta correlacionado com o fortalecimento da prática de uma educação ambiental crítica dentro do campus de Aquidauana, configurando-se como um projeto de ensino que tem por objetivo romper com os muros da universidade permitindo o acesso da comunidade do município aos conhecimentos e práticas produzidos pela comunidade acadêmica.

\section{DESCRIÇÃO DA EXPERIÊNCIA}

A formação do coletivo em 2017 resultou da ânsia de alunas do primeiro ano do curso de geografia da UFMS-CPAq, decididas a criar canteiros agroecológicos dentro do espaço da universidade, visando à garantia ao acesso de alimentos livres de agrotóxicos para pessoas envolvidas no projeto. Na atualidade o projeto conta com estudantes dos cursos de geografia, história, biologia, pedagogia e administração, tendo apoio de quatro docentes, três da biologia e um da geografia.

A organização do coletivo é feita por meio de reuniões publicas semanais onde ocorre o planejamento de atividades e é realizada a manutenção do espaço agroecológico. Sendo assim, o coletivo é gerido pelos discentes, onde todos interessados têm direito a participar e falar, e as decisões tomadas são debatidas buscando a construção de um consenso sobre as pautas.

Os docentes que têm se aproximado e colaborado no projeto respeitam essa forma de autogestão, participando das reuniões e atividades, mas sem imporem, de cima para baixo, suas perspectivas e opiniões.

As reuniões do coletivo possibilitaram a organização de um evento no primeiro semestre de 2018, intitulado: "primeira oficina de aprendizagem e agroecologia". A atividade foi aberta a comunidade, contando com a participação de discentes de outras instituições, munícipes e indígenas de aldeias da região. 0 evento contou com: palestra sobre sistemas agroflorestais, oficina de alporque, exposição do filme o veneno está na mesa e atividades culturais variadas (ver figura 1). 
Figura 1: a -cartaz da I Oficina de Aprendizagem e Agroecologia promovido em 2018 pelo coletivo b - foto da apresentação do espaço agroecológico para um grupo de participantes da oficina.

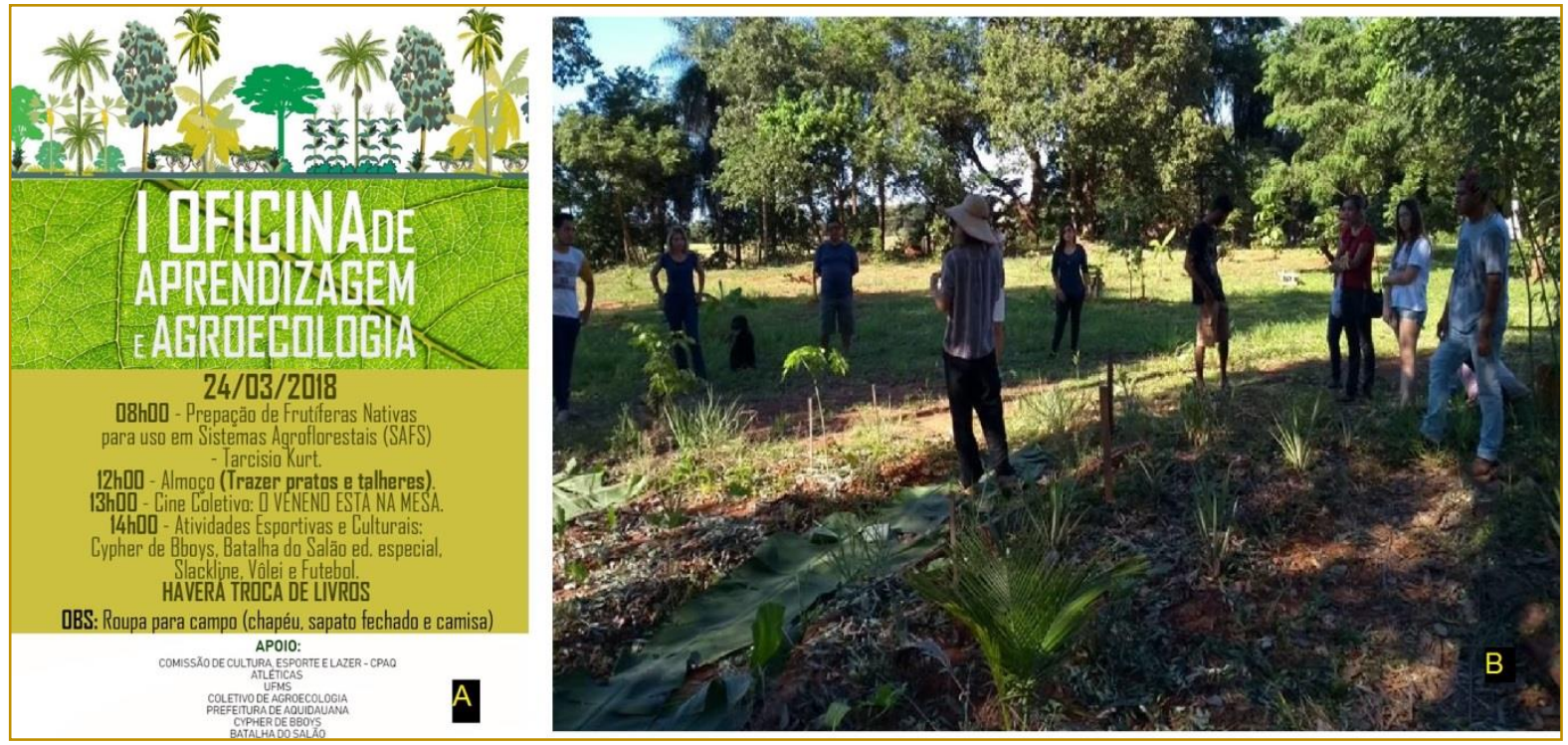

Outro fruto do coletivo foi o envio de um micro ônibus com discentes da universidade e estudantes de outras para a $14^{\circ}$ edição da feira de troca de sementes do município de Juti. Na feira os membros dos coletivos participaram de oficinas e palestras voltadas a produção agroecológica, bem como pro meio da troca e de doações conseguiram diversas sementes criolas que estão sendo usadas na área de manejo na universidade.

Quanto a pratica agroecológica as ações organizadas pelo coletivo, permitiram a introdução de uma área experimental de manejo agroecológico de baixo custo no campus em 2017. Os canteiros foram elaborados com base nos princípios expostos em EMBRAPA (2005). Dessa forma o espaço agroecológico busca: a) independência de insumos externos, adubos químicos e agrotóxicos; b) utilização de recursos renováveis e locais; c) reciclagem de nutrientes; d) uso de plantas nativas, policultura, diversidade funcional e genética; e) planejamento de sistemas adaptados às condições locais; f) incentivo à preservação e proliferação de sementes crioulas; g) estabelecimento de consórcios entre plantas; h) serviços ambientais; i) valorização do etnoconhecimento e saberes locais; j) fomento a segurança alimentar, geração de renda, agricultura familiar, acesso e permanência na terra; k) reconhecimento do papel dos mutirões e formas tradicionais de trabalho.

A área escolhida era subutilizada e degrada, a ação do coletivo vem aos poucos transformando a paisagem do local, que agora apresenta maior biodiversidade e circulação de pessoas.

O manejo iniciou com o plantio em consórcio de: abacaxi (Ananas comosus), feijão carioca (Phaseolus vulgaris), feijão de porco (Canavalia ensiformis), feijão guandu (Cajanus cajan) e cosmos (Cosmos bipinnatus).

Ao longo do trabalho tem sido introduzido nos canteiros outros cultivares entre eles: açafrão (cúrcuma longa), abóbora (cucurbita spp.), bananeira (Musa spp), babosa (Aloe vera chinensis), boldo (Peumus boldus) caju (Anacardium occidentale), cereja do rio grande (Eugenia involucrata), mandioca (Manihot esculenta), mamão (Carica papaya L.), pitanga (Eugenia uniflora), taioba (Xanthosoma sagittifolium) e terramicina (Alternanthera sp).

Sendo assim, os canteiros contam com plantas de diferentes funções e estratos. Entre os cultivares temos plantas que servem para: adubação verde, alimentação, uso medicinal e atração de polinizadores. 0 uso de plantas de diferentes estratos bem como a construção dos canteiros no sentido Sul-Norte tem por objetivo maximizar a fotossíntese (Ver figura 2). 
Figura 2: A- implementação dos primeiros canteiros em 10 de outubro de 2017

B - registro da condição atual dos canteiros agroecológicos realizado em 1 de março de 2019

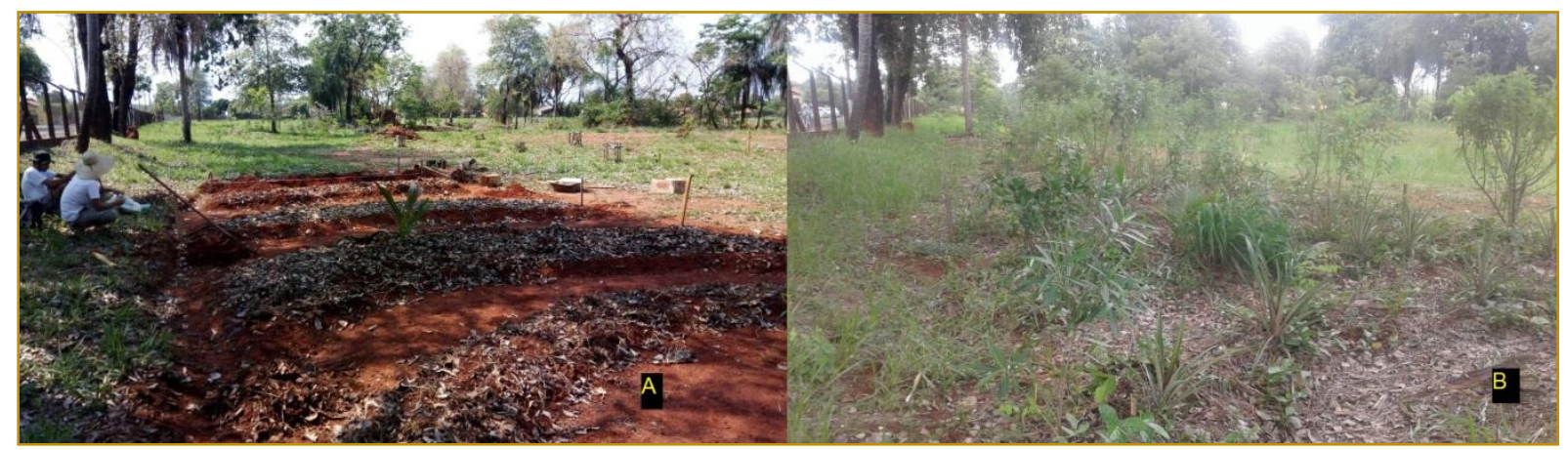

Como podemos verificar na figura 2 , o plantio nos canteiros tem sido feito de forma adensada e o solo tem sido protegido com cobertura biomassa visando: mitigar o processo erosivo, diminuir a temperatura da superfície, melhorar a retenção de água, favorecer a ciclagem de nutrientes e gerar condições para o desenvolvimento da micorriza, bem como da micro e macro fauna do solo.

Como o coletivo não possui aporte financeiro, optamos por um manejo de baixo custo de implementação. Dessa forma, os cultivares utilizados foram coletados ou doados por outros produtores agroecológicos, as ferramentas usadas são de membros do coletivo ou emprestadas por docentes que apoiam o projeto e optamos por plantas "valentes" que conseguem se desenvolver em solos não preparados e adubados.

Nesse sentido, acreditamos que o modelo que vem sendo aplicado pode ser facilmente replicável em outros lugares, sem a necessidade de grandes investimentos. Entendemos que dentro desse modelo o recurso mais importante são as pessoas interessadas em colaborar, estando dispostas a estudar e trabalhar colocando a mão na terra.

Seguindo as propostas de Ernest Gostch (1995, 1997 e 2015) buscamos uma agricultura que favorece os de processo, trabalhando no sentido de dinamizar o funcionamento dos ciclos biogeoquímicos que possibilitem a recuperação do ambiente por meio dos recursos locais e indo no caminho oposto de uma agricultura baseada em insumos que de forma recorrente necessita importar matéria e energia de outros locais para continuar produzindo.

Na figura 3 podemos observar um croqui dos canteiros e um registro fotográficos dos três primeiros canteiros.

Além dos canteiros, o coletivo de agroecologia da UFMS-CPAq, foi responsável pelo o plantio na universidade de 170 mudas de arvores doadas pelo Viveiro Municipal do Parque Natural da Lagoa Comprida de Aquidauana-MS. Nessa ação foram plantadas: 40 mudas de Ipe Roxo (Handroanthus avellanedae), 40 mudas de Ipê Amarelo (Handroanthus albus), 10 mudas de Ipê Branco (Tabebuia roseoalba), 10 Mudas de Jenipapo (Genipa americana), 10 mudas de Baru (Dipteryx alata), 20 mudas de Seriguela (Spondias purpúrea), 30 mudas de Tamarindo (Tamarindus indica) e 10 mudas de Caju Vermelho (Anacardium occidentale).

O coletivo também construiu uma espiral de ervas medicinais na universidade com o objetivo de fomentar o uso e o acesso dessas plantas na comunidade acadêmica, nesse contexto propomos uma discussão sobre o tratamento fitoterápico dos sintomas de doenças como depressão e ansiedade que são recorrentes no ambiente universitário. 
Figura 3. Croqui e Registros dos canteiros agroecológicos na UFMS-CPAQ, Aquidauana-MS.

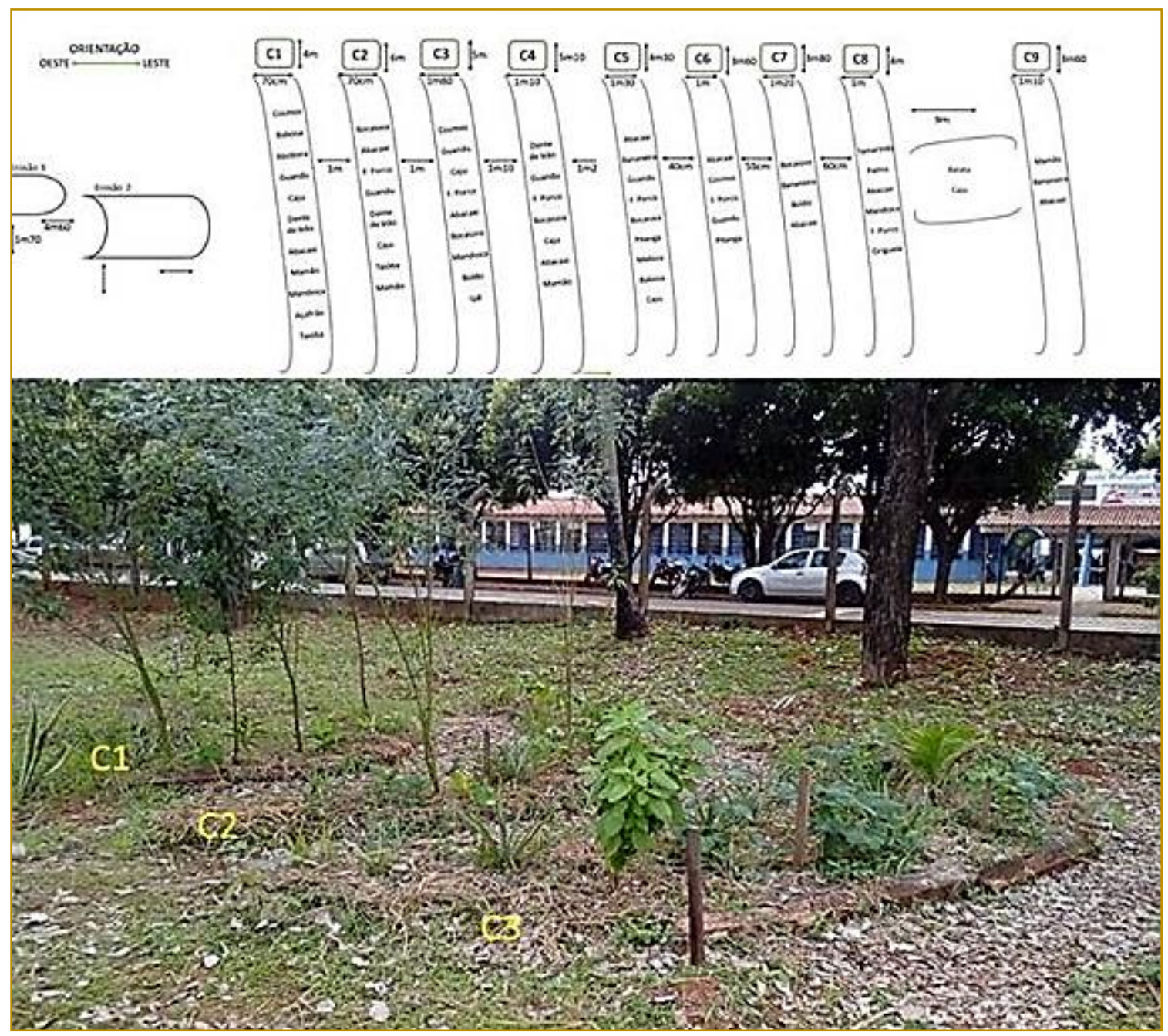

Outro projeto do coletivo é desenvolvido junto a Escola Estadual Marechal Deodoro da Fonseca, onde ao longo do segundo semestre de 2018, foram realizadas atividades de educação ambiental com foco na agroecologia e o manejo de cinco canteiros em transição agroecologia com alunos da escola (Figura 4).

Figura 4: A - construção da espiral de ervas medicinais na UFMS CPAQ

B - Alunos(as) da E.E. Marechal Deodoro da Fonseca fazendo a manutenção do espaço agroecológico

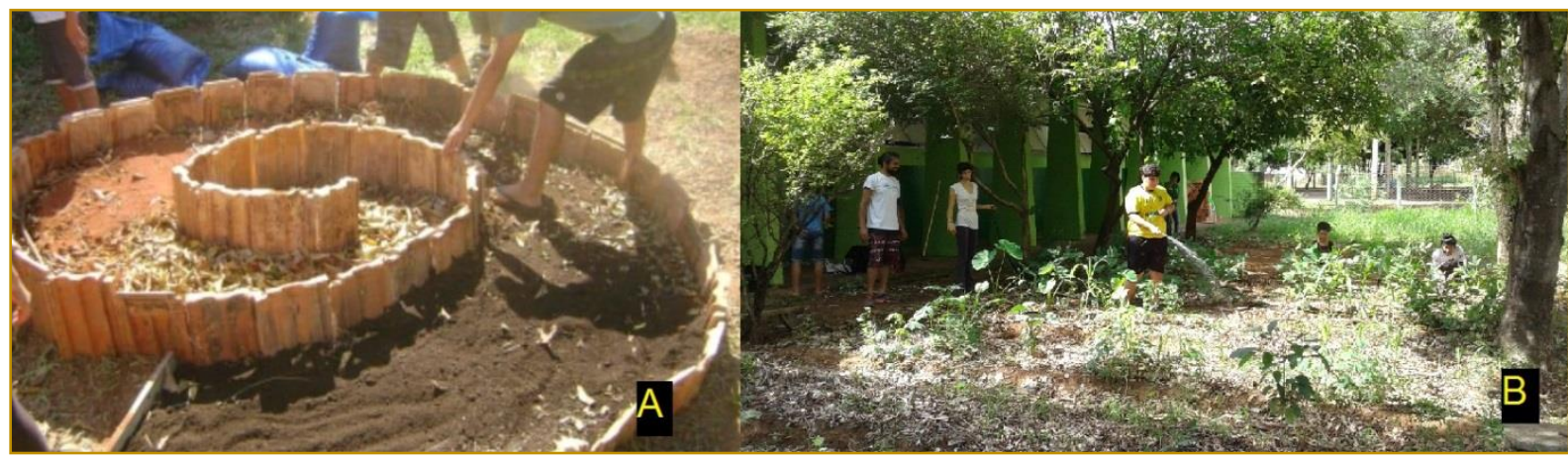


As atividades na escola ocorrem no período da tarde, com alunos(as) voluntários(as) que tem interesse em agroecologia. Os encontros buscam mesclar prática com teoria, por meio de uma abordagem lúdica. Entre as dinâmicas realizadas, servem de exemplo: café da tarde com coleta de sementes para produção de mudas, apresentação da diversidade genética das sementes usando diferentes fenótipos de milho, plantio consorciado de plantas, observação das estruturas das plantas da área de manejo e técnicas de conservação do solo utilizando biomassa.

0 trabalho do coletivo rompe com os limites da instituição acadêmica, incentivando que as pessoas participantes do projeto levem as práticas e conceitos discutidos no coletivo para sua vida cotidiana. Dessa forma. alguns membros do coletivo passaram a implementar quintais agroecológicos em suas casas (Figura 5)

Figura 5: A - plantio de mudas e manejo do solo de quintal agroecológico em 7/10/2017 B - Vista do quintal agroecológico em 5/03/2018

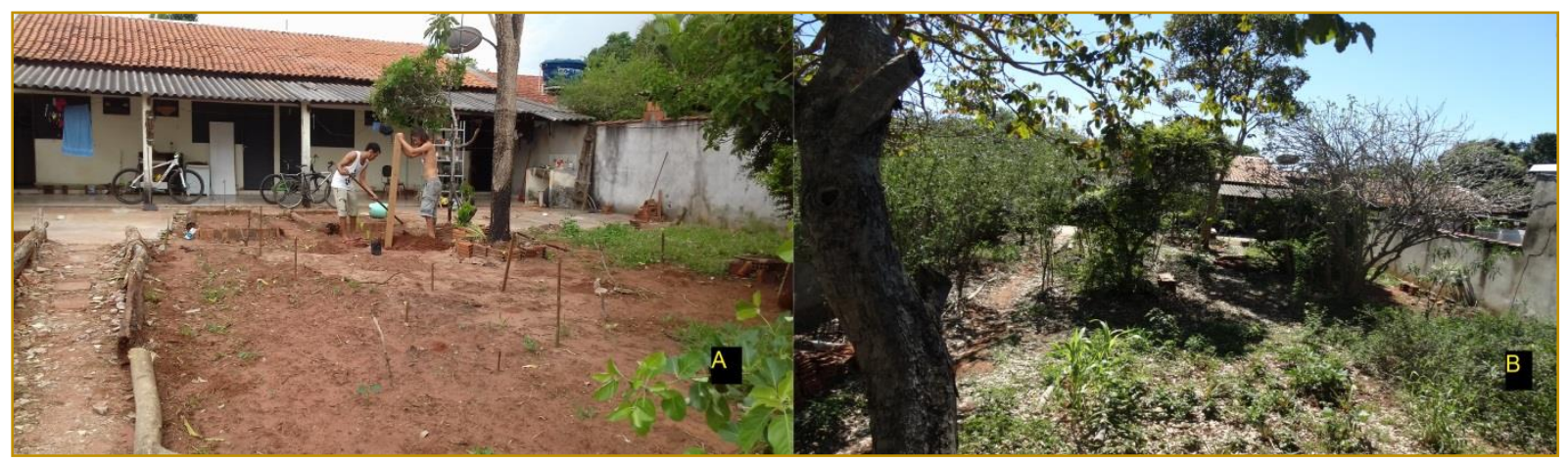

O quintal agroecológico presente na figura 5, é manejado por membros do coletivo que introduziram diversas plantas alimentares, medicinais e de adubação verde no quintal. Atualmente, entre as plantas desse quintal agroecológico temos, mais de 20 variedades de plantas: abacaxi (Ananas comosus), feijão carioca (Phaseolus vulgaris), feijão de porco (Canavalia ensiformis), feijão guandu (Cajanus cajan), cosmos (Cosmos bipinnatus). açafrão (cúrcuma longa), abóbora (cucurbita spp.), bananeira (Musa spp), babosa (Aloe vera chinensis), boldo (Peumus boldus), caju (Anacardium occidentale), mandioca (Manihot esculenta), mamão (Carica papaya L.), pitanga (Eugenia uniflora), taioba (Xanthosoma sagittifolium) e terramicina (Alternanthera $s p$ ), ora-pro-nóbis (Pereskia aculeata), café (Coffea), moringa oleífera, milho. (Zea mays), cintronela (cymbopogon), capim-limão (cymbopogon citratus), lambari-de-horta (stachys lanata), mamona (Ricinus communis L) e baru (Dipteryx alata). Além das plantas esse quintal agroecológico conta com uma composteira dando uma destinação adequada aos resíduos orgânicos produzidos pelos moradores.

Apesar do pouco tempo de existência, pouco mais de um ano, a energia investida pelos membros do coletivo está aos poucos gerando resultados, na forma de alimentos, pequenas mudanças na paisagem da universidade, mas, principalmente como provocação e questionamento sobre a sociedade em que estamos inseridos e da relação humanidade-natureza, dentro da UFMS-CPAq e na cidade de Aquidauana-MS.

\section{RESULTADOS}

O trabalho do coletivo está somente no começo, às sementes e ideias plantadas dentro desse projeto agroecológico vão se desenvolver aos poucos, uma vez que buscamos observar de forma crítica à lógica produtivista hegemônica, que almejando resultados rápidos, degrada o ambiente e explora pessoas.

Caminhar com calma, não significa imobilidade. Significa estabelecer um processo consciente e consistente, para que bem estruturado, possa ser duradouro e transformador, de modo que os envolvidos entendam o significado das ações nas quais estão inseridos, transformando-se ao longo do processo, gerando serviços ambientais e alimentos mais saudáveis, livres de agrotóxicos e adubos químicos, permitindo assim uma alimentação realmente saudável e compromissada com a segurança alimentar. 
Consideramos que um resultado importante desse trabalho é a consolidação de um núcleo de discentes que discute e pratica a agroecologia dentro da UFMS-CPAq e que transmitem esses debates para a população do município de Aquidauana-MS.

A falta de aporte financeiro e o desconhecimento inicial sobre as técnicas de plantio agroecológicos dificultaram o processo de desenvolvimento do coletivo, mas não inviabilizaram a ação dos envolvidos que estão aprendendo a encontrar soluções de baixo custo e conhecendo melhor por meio dos erros as necessidades do solo e das plantas.

Nossa experiência tem evidenciado que o conhecimento e debate teórico sobre agroecologia é importante, porém a pratica é fundamental, muitos princípios e conceitos somente ficam claros quando observados no espaço de manejo agroecológico.

Após um ano de trabalho, o coletivo conseguiu criar um banco de sementes de adubação de verde e colheu alguns frutos que foram utilizados na alimentação dos envolvidos diretamente no projeto.

Outro resultado que consideramos significativo é o uso dos canteiros de manejo agroecológico para a realização de atividades praticadas por docentes do curso de biologia, isso demonstra o potencial pedagógico do espaço.

É importante destacarmos que a existência do manejo tem movimentado uma parte do campus antes abandonada e degrada que agora conta com a circulação e os cuidados dos discentes, tendo tido sua paisagem modificada aos poucos.

Por fim, destacamos a força transformadora que um grupo organizado de pessoas possui, mesmo com pouco apoio, o coletivo tem perpetrado transformações teóricas e concretas dentro da UFMS-CPAq, servindo como uma pequena fissura na realidade perversa na qual estamos inseridos. Abrindo frestas proliferam esperanças. Porém, mesmo defendendo o potencial transformador da sociedade organizada, não podemos deixar de frisar a importância que políticas públicas possuem para expansão da agroecologia e na construção de uma sociedade mais justa socialmente e menos degradante do ambiente.

\section{REFERÊNCIAS}

[1] Altieri, M Agroecologia: a dinâmica produtiva da agricultura sustentável. 4.ed. Porto Alegre: Editora da UFRGS, 2004

[2] Antonio, L.; Sant'ana, G.; Melo, A. (Orgs.). O curso Agricultor Agroflorestal na promoção da autonomia Terena: uma articulação entre a Família GATI (Organização CAIANAS), Projeto GATI e IFMS/PRONATEC. - Brasília: Projeto GATI/FUNAI, 2016.79p. Ilust.

[3] Bombardi, L. M. Geografia do Uso de Agrotóxicos no Brasil e Conexões com a União Europeia - São Paulo: FFLCH - UPS, 2017. P. 296

[4] Cunha, A. P. Diálogos entre geografia e Agroecologia: Reflexões sobre território, desenvolvimento e colonialidade in: Terra Livre, São Paulo, Ano 29, Vol. 2, n43, p. 170-205.

[5] Embrapa, Marco referencial em agroecologia, Brasília, DF, EBRAPA Informação Tecnológica, 2006, p.70.

[6] Gonçalves, Carlos Walter Porto. (Des)caminhos do meio ambiente. ed. 14 São Paulo: Contexto, 2006. p.148.

[7] Gonçalves, Carlos Walter Porto. A Globalização da Natureza e a Natureza da Globalização. Rio de Janeiro: Civilização brasileira, 2006.

[8] Gotsch, E. O Renascer da Agricultura. Centro Sabiá, Recife, 1995

[9] Götsch, E. Homem e Natureza: cultura na agricultura. 2. ed. Recife: Centro Sabiá, 1997.

[10] Götsch, E. Vídeo: Life in Syntrop. Produzido por Agenda Gotsch, 2015. Disponível em: <http://agendagotsch.com>. Acesso: fev. 2019.

Iha, M. H. A apropriação da agroflorestal como forma de afirmação da reforma agrária: um estudo sobre o processo de recampesinização no Assentamento Mário Lago em Ribeirão Preto-SP. Tese (doutorado em geografia), Universidade de São Paulo, 2017. 311 f. 


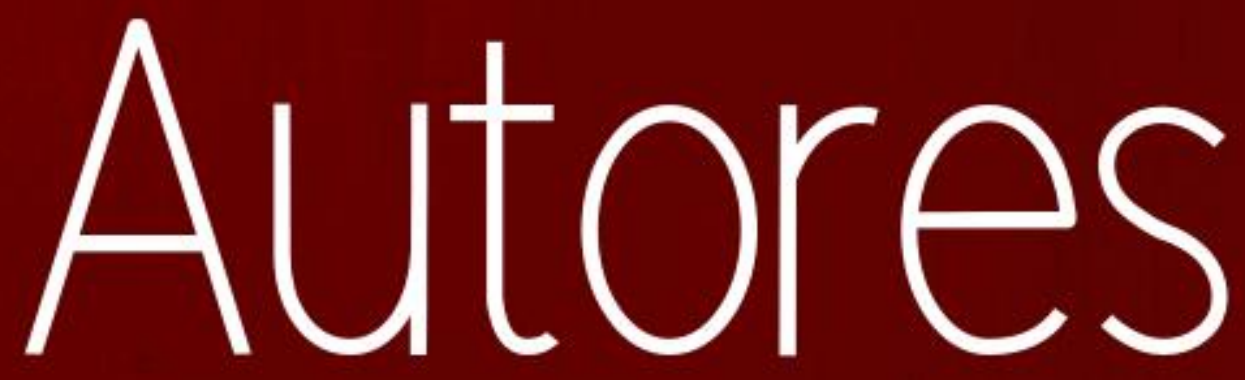




\section{ADRIANA MATHEUS DA COSTA SORATO}

Doutorado em Estatística e Experimentação Agropecuária pela Universidade Federal de Lavras, com mestrado na mesma área e instituição e graduação em Licenciatura em Matemática pela Universidade Estadual Paulista. Atualmente, professora da Universidade do Estado do Mato Grosso (UNEMAT).

\section{AMURIM-SANTANA, MARIA JUANNA MARQUES DE}

Acadêmica do curso de Ciências Biológicas - Licenciatura, da Universidade Federal da Grande Dourados. Bolsista no Programa de Educação Tutorial - PET Ciências Biológicas da Faculdade de Ciências Biológicas e Ambientais.

\section{ANA CAROLINA DOMINGOS MALUF}

Possui graduação em Ciências Biológicas pela Universidade Federal de Mato Grosso do Sul (2018). Tem experiência na área de Botânica, com ênfase em plantas alimentícias não convencionais e plantas medicinais. É membro do Grupo de Agroecologia AHOW, em Três Lagoas/MS.

\section{ANA CAROLINY DE QUEIROZ FERNANDES}

Mestranda pelo Programa de Pós Graduação em Biologia Geral e Bioprospecção e graduada em Ciências Biológicas pela Fundação Universidade Federal da Grande Dourados - UFGD.

\section{ANA PAULA RODRIGUES DA SILVA}

Acadêmica de Licenciatura e bacharelado em Ciências Biológicas pela Universidade do Estado de Mato Grosso campus Alta Floresta. Com experiencia em Laboratório de Microbiologia e Fitopatologia.

\section{ANDREIA VASCONCELLOS}

Técnica Agropecuária pela Escola Assis Chateubriand - EAAC no ano de 2005. Em 2012, formou-se como Bacharela em Agroecologia pela Universidade Estadual da Paraíba - UEPB. Em 2008, é aprovada em Licenciatura em Ciências Agrárias pela Universidade Federal da Paraíba - UFPB. Obteve aprovação no Programa de Pós-Graduação em Ciências Agrárias (Agroecologia), pela Universidade Federal da Paraíba no ano de 2014. Formou-se Especialista em Agroecologia pela Universidade Estadual da Paraíba no ano de 2016. Atualmente faz parte do Programa de PósGraduação em Extensão Rural pela Universidade Federal de Santa Maria - UFSM (com previsão de término em 2020).

\section{ANTONIO CARLOS MONTEIRO FILHO}

Graduação em andamento em Biologia

\section{BRUNO TADEU LOPES}

Estudante de Agronomia pela Universidade Federal Rural do Rio de Janeiro; Consultor Técnico em Agropecuária na empresa Ecoaba.

\section{CAMILA CRISTINA NASCIMENTO}

Estudante do curso de Agronomiapela Universidade Federal Rural do Rio de Janeiro. Experi encia com projetos de extensao para levantamento socio-econômico e ambiental de moradores de zona rural da Baixada Fluminense. 


\section{CAMILO ALEJANDO BUSTOS AVILA}

É Professor Adjunto I da Universidade Federal do Mato Grosso do Sul Campus Aquidauana. Possui graduação em Geografía - Universidad Nacional de Colombia; mestrado em Geografia (Geografia Humana) pela Universidade de São Paulo (2008) e doutorado em Geografia (Geografia Humana) pela Universidade de São Paulo (2012). Fez estágio de pós-doutorado na Universidade de São Paulo vinculado ao AGRÁRIA-USP. Laboratório de Geografia Agrária do Departamento de Geografia .É colaborador do NERA "Núcleo de Estudos em Reforma Agrária e Colonização" da FCT- UNESP de Presidente Prudente e revisor da Revista Agrária do Laboratório de Geografia Agrária -USP.Tem experiência em Geografia Humana, em áreas como Geografia Agrária e Teoria e Método em Geografia.

\section{CLARIANA VILELA BORZONE}

Possui Graduação em Cinema e Vídeo pela Universidade Estadual do Paraná (2013), e Mestrado em Geografia, na área de Análise Geoambiental e Produção do Território, na UFMS - Câmpus Três Lagoas (2018). Participou do Laboratório de Estudos Territoriais (LABET) e do Núcleo de Extensão em Desenvolvimento Territorial (NEDET), atuando como Assessora de Gênero no Território Rural do Bolsão. É membro do Grupo de Agroecologia AHOW, em Três Lagoas, e atualmente trabalha como Produtora Audiovisual na empresa Black Mídia.

\section{CLAUDIA MARCIA LYRA PATO}

Doutora em Psicologia pela Universidade de Brasília (2004), pesquisadora visitante no Applied Social Psychology Laboratory da California State University San Marcos - CSUSM e pós-doutorado em Psicologia Ambiental na mesma instituição, sob supervisão do professor P. Wesley Schultz, PhD (Abril/2017-Maio/2018). Coordenadora do Programa de Pós-Graduação em Educação da Universidade de Brasília - UnB (Novembro/2018 a Novembro/2020). Professora da Faculdade de Educação da Universidade de Brasília nos níveis de graduação e pós-graduação. Líder do Grupo de Estudos e Pesquisas em Educação Ambiental e Ecologia Humana - GEPEAEH. Participa de grupos de pesquisa na área de Valores Humanos, Educação, Relações e Interrelações com o Comportamento Ecológico, com interface das áreas de Psicologia Social, Psicologia Ambiental e Educação Ambiental. Eleita coordenadora do GT de Psicologia Ambiental da ANPEPP e coordenadora do GT22 de Educação Ambiental da ANPED CO para o biênio 2018-2020. Eleita coordenadora do Programa de Pós-Graduação em Educação da Universidade de Brasília para o biênio 2018-2020.

\section{CLEIDE BRACHTVOGEL}

Mestranda pelo Programa de Pós Graduação em Biologia Geral e Bioprospecção e graduada em Ciências Biológicas pela Fundação Universidade Federal da Grande Dourados - UFGD.

\section{CORREA, TABATA ALVES}

Acadêmica do curso de Ciências Biológicas - bacharelado, na Universidade Federal da Grande Dourados - UFGD. Bolsista no Programa de Educação Tutorial em Ciências Biológicas. Atualmente trabalha na pesquisa em Ecologia de epífitas vasculares.

\section{DANIEL CARLESSO}

Estudante de graduação na Universidade do Estado de Mato Grosso, cursando o curso de Engenharia Agronômica, ensino médio completo, disponibilidade para novos aprendizados 


\section{DIANE IVANISE FIAMONCINI}

Possui graduação em Ciências Biológicas Licenciatura pela Universidade Federal de Santa Catarina (1990), Mestrado em Educação, com ênfase em Educação Ambiental, pela Universidade do Vale do Itajaí (2006) e Doutorado em Educação, pela Universidade de Brasília (2018). Atualmente é professora no Instituto Federal de Brasília nos cursos de Licenciatura em Biologia e Superior de Tecnologia em Agroecologia. É Coordenadora do Curso Superior de Tecnologia em Agroecologia do Instituto Federal de Educação, Ciência e Tecnologia de Brasília, Campus Planaltina. Tem experiência na área de Educação e Meio Ambiente tendo atuado com coletivos jovens pelo meio ambiente, recursos hídricos, agroecologia e educação ambiental.

\section{DIOCLÉA ALMEIDA SEABRA}

Graduação em Agronomia, Mestrado em Agronomia, Doutorado em Ciências Agrárias

\section{DUALYSON DA SILVA SANTOS}

É Bacharel em Agroecologia na Universidade Federal da Paraíba do Centro de Ciências Humanas, Sociais e Agrárias, Campus III - Bananeiras/PB,Participou do Grupo de Estudos do Laboratório de Solos, sob a orientação da professora Belísia Lúcia T. Diniz, e do Núcleo de Pesquisa e Estudos em Forragicultura, orientado pela professora Ana Patrícia Bezerra,participou do Laboratório de Tecnologia de Sementes,aluno bolsista de extensão modalidade IEX 2012 - 2013 do Programa de Extensão intitulado de AGROECOLOGIA: UMA PROPOSTA PARA A CONSTRUÇÃO E PARA O FORTALECIMENTO DOS SABERES DA AGRICULTURA, projeto este coordenado e orientado pelo professor Fillipe Silveira Marini, ambos na Universidade Federal da Paraíba, Centro de Ciências Humanas Sociais e Agrárias, Campus III - Bananeiras/PB,realiza diversos cursos pelo SENAR, FUNDAÇ̃̃o GETÚLIO VARGAS,voluntario PIBIC/ CNPq 2014 ? 2015 e 2015 -2016 com o projeto ESPAÇAMENTOS DE LEGUMINOSAS PARA A PRODUÇÃO DE SEMENTES NO SEMIÁRIDO PARAIBANO.Cursando especialização em Psicopedagogia institucional e clinica pela universidade são Judas Tadeu, cursando Curso Técnico em Nutrição e Dietética na instituição de ensino Colégio Agrícola Vidal de Negreiros CAVN - CCHSA/UFPB.

\section{EDILSON BRAGA RODRIGUES}

Ensino Profissional de nível técnico em Técnico em Agropecuária pela Escola Agrotécnica Federal de Barbacena, Brasil (1989). Graduação em Gestão Ambiental. Técnico da Empresa Brasileira de Pesquisa Agropecuária, Brasil. Tem experiência com agroecologia e produção orgânica, fruticultura, horticultura, avicultura, compostagem, biofertilizantes e fitossanidade.

\section{ETZTLI ITZEL MORALES REYES}

Doutoranda em Ciências Ambientais na Universidade Autônoma do Estado de México (UAEMéx), possui um Mestrado em Ciências Ambientais em 2014 pela mesma universidade e é graduada em Engenharia Agronômica pela Faculdade de Ciências Agrícolas da UAEMéx. Tem experiência nas linhas de pesquisa: desenvolvimento rural sustentável; pesquisa de ação participativa; agricultura orgânica; agroecologia; cafeicultura.

\section{FILLIPE SILVEIRA MARINI}

Possui graduação em Agronomia pela Universidade Federal de Viçosa (UFV), mestrado e doutorado em Produção Vegetal pela Universidade Estadual do Norte Fluminense Darcy Ribeiro (UENF). Atualmente é professor Associado, Coordenador do Núcleo de Extensão e Desenvolvimento Territorial e Agroecologia (NEDET) da Universidade Federal da Paraíba (UFPB), Campus I; Membro do NDE de Geografia/UFPB e Avaliador institucional pelo INEP/MEC. Foi coordenador do Programa de Pós-Graduação em Ciências Agrárias (Agroecologia)/UFPB. As áreas de interesse profissional são Agroecologia e Extensão Rural, atuando principalmente nos seguintes temas: agricultura familiar, manejo de agroecossistemas, tecnologia de sementes, políticas públicas, desenvolvimento rural e diagnóstico rural participativo (DRP). 


\section{FRANCIELI APARECIDA ZENATTI}

Formada no Curso de Licenciatura em Educação do Campo (LEDUC) da Faculdade Intercultural Indígena (FAIND) na Universidade Federal da Grande Dourados (UFGD), com habilitação em Ciências da Natureza.

\section{FRANCISCO BRAZ DALEPRANE}

Professor do Instituto Federal de Educação, Ciência e Tecnologia do Espírito Santo, IFES-Campus Santa Teresa; Graduado em Licenciatura em Ciências agrícolas pela Universidade Federal Rural do Rio de Janeiro; Especialista em Nutrição Mineral de Plantas pela Universidade de São Paulo - USP; Especialista em Agricultura Tropical pela Universidade Federal Rural de Pernambuco; Mestre em Ciências pela Universidade Federal Rural do Rio de Janeiro; Doutorando em Produção Vegetal pela Universidade Estadual do Norte Fluminense Darci Ribeiro - UENF

\section{GABRIEL APARECIDO SALDANHA}

Cursa licenciatura em História na Universidade Federal de Mato Grosso do Sul, Campus de Aquidauana (2016-atual). Monitor voluntário de Educação Ambiental no projeto Expedições Anarco Pedagógicos Atemporais. Desenvolveu pesquisa de iniciação científica intitulada "Amor à Vida" nas páginas impressas (2013 a 2014). Membro do Núcleo de Estudos Afro-Brasileiros e Indígenas (Neabi-IFMS). Bolsista de iniciação científica com a pesquisa "Os documentos finais das Grandes Assembleias do Povo Terena e a construção da memória coletiva". Atualmente é membro do projeto de ensino do Coletivo de Agroecologia.

\section{GABRIEL LOSCHIAVO CERDEIRA}

Atualmente cursa Mestrado em Geografia, com bolsa CAPES, na Universidade Federal de Mato Grosso do Sul, Câmpus de Aquidauana (UFMS-CPAq). Licenciado e bacharelado no Curso de Geografia da Faculdade de Ciências e Tecnologia - FCT/UNESP/Presidente Prudente (2009-2013), possuindo Pós-Graduado Latu Sensu em História da América na UFMS-CPAq (2017-2018). Membro do Laboratório de Arqueologia Guarani (LAG), desde 2009. Bolsista de iniciação científica FAPESP com a pesquisa intitulada "Estudo dos sítios arqueológicos Turvo V-A e Turvo V-B, Bacia do rio Turvo/Grande: interfaces com a arqueologia da paisagem" (2011-2013), sob orientação da Profa. Dra. Neide Barrocá Faccio. Colaborador do coletivo de agroecologia da UFMS-CPAq (2017-atual).

\section{GISELE MARTINS GUIMARÃES}

Professora do Programa de Pós Graduação em Extensão Rural e do Departamento de Educação Agrícola e Extensão Rural da Universidade Federal de Santa Maria (UFSM) . Pesquisadora e Consultora técnica nas seguintes linhas temáticas: Desenvolvimento Rural Sustentável, Agricultura Familiar, Agroecologia, Agroindústrias Familiares Rurais, Economia Solidária, Extensão e Comunicação Rural.

\section{GISEUDO APARECIDO DE PAIVA}

Acadêmico de Licenciatura e bacharelado em Ciências Biológicas pela Universidade do Estado de Mato Grosso campus Alta Floresta. Com experiencia em Laboratório de Microbiologia e Fitopatologia.

\section{GRACE QUEIROZ DAVID}

Professora da Universidade do Estado de Mato Grosso, trabalha na área de controle biológico de doenças de plantas e microbiologia agrícola. Atualmente cursa o doutorado em sistemas de produção (UNESP- Ilha Solteira) 


\section{IARA AQUINO HENN}

Possui graduação em Pedagogia pela Universidade Regional do Estado do Rio Grande do Sul (1997), mestrado em Educação Nas Ciências pela Universidade Regional do Noroeste do Estado do Rio Grande do Sul (2006) e doutorado em Antropologia Social - UNIVERSIDAD NACIONAL DE MISIONES - Fac. de Humanidades y Ciencias Sociales (2012). Atualmente é professora no Ensino, Básico, Técnico e Tecnológico do Instituto Federal do Paraná, Campus Palmas. Tem experiência na área de Antropologia, com ênfase em Antropologia Rural e na área da Educação Básica e Superior, atuando na formação de professores nos seguintes temas: Educação do Campo, Educação Inclusiva, Estágios Supervisionados obrigatórios, Educação em Direitos Humanos e Didática. Atua na coordenação de área do Programa Institucional de Bolsas de Iniciação à Docência (Pibid) no Sub Projeto de Pedagogia.

\section{JAIME RODRIGO DA SILVA MIRANDA}

Atualmente, professor efetivo da área Extensão Rural e Metodologia da Ciência pela Universidade Federal Rural do Rio de Janeiro (UFRRJ), desde 2010. Graduado em Zootecnia e Mestre em Extensão Rural pela Universidade Federal de Viçosa -UFV. Experiência prática de 6 anos como Extensionista Rural e desenvolvimento da agricultura familiar em áreas de reforma agrária na Amazônia. Professor voluntário na aéra Sociologa Rural pela UFV em 2008 e professor efetivo da área Extensão Rural e Economia Rural pela Universidade Federal Rural da Amazônia (UFRA) de 2009 a 2010.

\section{JESSICA FERREIRA DA SILVA}

Doutoranda pelo Programa de Pós Graduação em Ciência e Tecnologia Ambiental pela Fundação Universidade Federal da Grande Dourados - UFGD, Mestre em Recursos Naturais e graduada em Engenharia Ambiental pela Universidade Estadual do Mato Grosso do Sul.

\section{JOÃO NACIR COLOMBO}

João Nacir Colombo, possui graduação em Licenciatura em Ciências Agrícolas pela Universidade Federal Rural do Rio de Janeiro - UFRRJ - (1990); Mestrado em Educação Agrícola pela UFRRJ (2006) e doutorado em Fitotecnia pela Universidade Federal de Viçosa - MG (2013); Atualmente é Professor Titular de Educação Básica, Técnica e Tecnológica do Instituto Federal do Espírito SantoCampus Santa Teresa; Tem experiência de vinte e seis anos na área de Educação agrícola, com ênfase em Olericultura e Agroecologia. Desenvolveu vinte projetos, possui dezenove artigos completos publicados em periódicos e orientou seis trabalhos de conclusão de curso de graduação. Atualmente é revisor das revistas Caatinga e Cadernos de Agroecologia.

\section{JOÃO TORRES FRANCO BORGES LIMA}

Atualmente aluno da Universidade Federal de Goiás - UFG, no curso de agronomia situada em Goiânia no campus Samambaia. Membro do grupo de estudo em manejo agroecológico dos solos (GEMAS) e do projeto CNPq, o qual realiza atividades nas áreas de inovação tecnológica e assistência técnica rural. Monitor voluntario na disciplina de desenho técnico no ano de 2014. Pesquisador na área de produção orgânica, em busca de alternativas sustentáveis para o meio ambiente.

\section{JÔINE CARIELE EVANGELISTA DO VALE}

Bióloga, Mestranda do Programa de Pós Graduação em Stricto Sensu em Biodiversidade e Agroecosistemas Amazônicos (PPGBioAgro) pela Universidade do Estado do Mato Grosso (UNEMAT) 


\section{JORGE FEDERICO ORELLANA SEGOVIA}

Possui graduação em engenharia agronômica pela Universidade Federal Rural da Amazônia (1980), mestrado em Agronomia pela Universidade Federal de Santa Maria (1995) e doutorado em DESENVOLVIMENTO SUSTENTÁVEL DO TRÓPICO ÚMIDO pela Universidade Federal do Pará (2011). Atualmente é pesquisador da EMPRESA BRASILEIRA DE PESQUISA AGROPECUÁRIA. Tem experiência na área de Agronomia, com ênfase em Produção Vegetal, atuando principalmente nos seguintes temas: prospecção espécies vegetais medicinais e ornamentais da flora amapaense, produtos bioativos, analise crescimento vegetal e produção de olericolas. Recentemente atua em pesquisas de socioeconomia e desenvolvimento da base agrária.

\section{JOSIANE RODRIGUES MIOLLO}

Zootecnista. Mestranda do Programa de Pós Graduação em Extensão Rural da Universidade Federal de Santa Maria (UFSM). Pesquisadora nas temáticas de Agroecologia, Agricultura Familiar e Conservação de Fauna Silvestre

\section{JULIA CAROLINE MACHADO DE ARAUJO}

Cursa licenciatura em Pedagogia na Universidade Federal de Mato Grosso do Sul, Campus de Aquidauana (2017-atual). Coordenadora de formação política e movimentos sociais no diretório acadêmico da UFMS, Campus de Aquidauana. Atualmente é membro do projeto de ensino do Coletivo de Agroecologia

\section{JULIA FRANCO STUCHI}

Doutoranda em Biodiversidad e Agroecología na Universidad de Córdoba (UCO, Espanha), possui pós-graduação em Agrofloresta Tropical pelo Centro Agronómico Tropical de Investigación y Enseñensa (CATIE, Costa Rica) em 2009. Graduação em Engenharia Florestal pela UNESP-FCA, Brasil em 2007. Tem experiência nas áreas de sistemas agroflorestais, agroecologia e desenvolvimento sustentável, agricultura familiar, assentamentos da reforma agrária, comunidades agrícolas, etnobotânica e formação de lideranças comunitárias. Estudou e trabalhou no Brasil (nos estados de São Paulo, Amazonas, Acre, Amapá e Rio de Janeiro) e no exterior (Estados Unidos, Costa Rica e Colômbia). Atualmente exerce suas funções laborais na Embrapa Solos na área de agricultura familiar e agroecologia.

\section{JULIANA FERREIRA DE LIMA}

Mestranda em Ciências Agrárias (Agroecologia) pelo Programa de Pós-graduação em Ciências Agrárias (Agroecologia) UFPB/CCHSA, sob a orientação do Prof. Drº Alexandre Eduardo de Araújo. Bacharela em Agroecologia, pela na Universidade Federal da Paraíba, Centro de Ciências Humanas Sociais e Agrárias, Campus III - Bananeiras/PB. Técnica Agrícola com Habilitação em Agroindústria pelo Colégio Agrícola Vidal de Negreiros UFPB/CCHSA. Participou do Grupo de Estudos do Laboratório de Solos, do Núcleo de Pesquisa e Estudos em Forragicultura, participa do Núcleo de Agroecologia da UFPB Campus III. Atuou dois anos no Laboratório de Tecnologia de Sementes como bolsista em um projeto de extensão titulado de: Resgate e Mapeamento dos Guardiões das Sementes da Paixão e estratégias para Manutenção da Agrobiodiversidade no território da Paraíba, coordenado e orientado pelo professor Fillipe Silveira Marini, ambos na UFPB/CCHSA, Campus III Bananeiras/PB. Atuou auxiliando o projeto de pesquisa na área de sementes de leguminosas como estratégia para resgate e manutenção da fertilidade do solo. Alfabetizadora do programa Brasil Alfabetizado de 2010-2015. Atuou oito meses como instrutora do ProJovem Trabalhador do Curso de Agroextrativismo, no município de Serraria/PB, onde desenvolve atividades de produção de horta, pomares e e exploração consciente dos recursos florestais, levando assim uma socialização de conhecimento para os estudantes e o meio rural de maneira à produzir alimentos preocupandose o futuro, conservando assim, a agrobiodiversidade local e formando cidadãos éticos e conscientes. Faz parte do Conselho Municipal de Desenvolvimento Rural Sustentável e da Comissão de Meio Ambiente do Município de Serraria/PB. É representante municipal do Colegiado da Borborema e do Consórcio Intermunicipal de Resíduos Sólidos que tem como sede o município de Guarabira, ambas representações são do município de Serraria/PB. Tendo realizado diversos 
cursos pelo SENAR, Fundação Getúlio Vargas, Programa Brasil Solidário, CG Control Informática, UFPB, Pastoral da Criança, MDA, entre outros. Coordenou o Projeto ;Brincando e Evangelizando;, uma ação da Pastoral da Criança do município de Serraria/PB, comunidade José Lins Sobrinho no período de 2015-2017. Representante titular do Comitê de Bacias Hidrográficas do Litoral Norte (2015-2018), e suplente do mesmo comitê no período de 2018-2021. Atuou durante 3 anos na Secretaria de Agricultura e Meio Ambiente do município de Serraria/PB, desenvolvendo trabalhos voltados ao homem do campo e meio ambiente, tais como acompanhamento e implementação do Programa Garantia Safra durante as safras 2013, 2014, 2015 e 2016, cadastro e atualização de ITR e SNCR/INCRA, acompanhamento de projeto para execução de um Sistema Simplificado de Abastecimento de Água na Comunidade Pau Barriga, idealização e implementação da Feira da Agricultura Familiar de Serraria que atualmente é um Organismo de Controle Social cadastrado no MAPA, entre outras ações voltadas à agricultura familiar.

\section{JÚLIO CÉSAR PEREIRA LOBTCHENKO}

Mestrando pelo Programa de Pós Graduação em Biologia Geral e Bioprospecção e graduado em Ciências Biológicas pela Fundação Universidade Federal da Grande Dourados - UFGD.

\section{KAROLAINY SOUZA GOMES}

Eng a Agrônoma pela Universidade Federal Rural da Amazônia (UFRA)

\section{KAROLINE ROBERTA DA SILVA COSTA}

Graduação em andamento em Biologia

\section{KRISHNA DE NAZARÉ SANTOS DE OLIVEIRA}

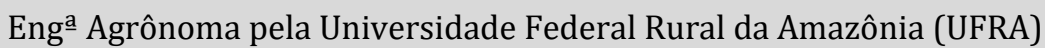

\section{LARISSA OLIVEIRA VILELA}

Mestranda pelo Programa de Pós Graduação em Ciência e Tecnologia Ambiental e graduada em Ciências Biológicas pela Fundação Universidade Federal da Grande Dourados - UFGD.

\section{LEILA MAIARA DE OLIVEIRA CORRÊA}

Estudante de graduação na Universidade do Estado de Mato Grosso, cursando o curso de Engenharia Agronômica, ensino médio completo, disponibilidade para novos aprendizados.

\section{LUAN DANIEL SILVA FERREIRA}

Graduação em andamento em Biologia

\section{LUANA SOUZA SILVA}

Estudante de Agronomia pela Universidade do Mato Grosso - UNEMAT e bolsista de iniciação cientifica.

\section{LUANY ALVES GALVÃO}

Licenciada e Bacharel em Ciências Biológicas

\section{MARCELO SOLON SICUTO}

Acadêmico do curso de Direito na Instituição FADAF, de Alta Floresta-MT. 


\section{MARIA DO SOCORRO PIRES SOUZA}

Enga Agrônoma pela Universidade Federal Rural da Amazônia (UFRA)

\section{MARIA JOSÉ NETO}

Natural de Lençóis Paulista, possui graduação em CIÊNCIAS BIOLÓGICAS pela UNIVERSIDADE ESTADUAL PAULISTA-Unesp-CAMPUS DE BOTUCATU (1985), mestrado em Ciências Biológicas Botânica (1990) pela mesma Instituição e doutorado em Agronomia-Sistemas de ProduçãoConceito 5 da CAPES (2010) pela Faculdade de Engenharia de Ilha Solteira-Unesp. É professora associada da Universidade Federal de Mato Grosso do Sul.Atua em Botânica nas subáreas de Morfologia e Taxonomia Vegetal. Trabalha com florística em Cerrados, plantas ruderais e medicinais.

\section{MARIA RAIMUNDA ARAÚJO SANTANA}

Possui doutorado em Ecologia e Desenvolvimento Sustentável pelo Colégio da Fronteira Sul, México, com mestrado em Manejo e Conservação de Florestas Tropicais e Biodiversidade pelo CATIE, Costa Rica e, graduação em Turismo pela Universidade Federal do Pará (UFPA), Brasil. Possui experiência, desde 1997, como professora e pesquisadora em temas socioambientais. Atualmente é Coordenadora de cursos de capacitação de projetos de pesquisa do Instituto Trilhas, localizado na cidade de San Cristóbal de Las Casas, México.

\section{MARIANA ZANDOMÊNICO MANGEIRO}

Graduada em Agronomia pelo Instituto Federal do Espirito Santo; Mestranda em Produção Vegetal pela Universidade Estadual do Norte Fluminense Darci Ribeiro - UENF

\section{MIGUEL ÁNGEL BALDERAS PLATA}

Possui Mestrado e Doutorado pelo Colégio de Pós-graduação de Chapingo, México, é Professor pesquisador da Faculdade de Geografia na Universidade Autónoma do Estado do México (UAEMéx), na cidade de Toluca. É responsável pelo Laboratório de Edafologia. Atua nas linhas de pesquisa: Manejo sustentável e poluição de solos.

\section{PAZ, FRANCIELE NOGUEIRA}

Acadêmica do curso de Ciências Biológicas - Bacharelado, da Universidade Federal da Grande Dourados (UFGD). Bolsista do Programa de Educação Tutorial - PETBio/UFGD e membro do Laboratório de Restauração Ambiental (LABRA) pela mesma instituição.

\section{PEREIRA, ZEFA VALDIVINA}

Possui Graduação em Ciências Biológica pela Universidade Federal de Mato Grosso do Sul (2000), Mestrado em Botânica Pela Universidade Federal de Viçosa (2003), Doutorado em Biologia Vegetal Pela Universidade Estadual de Campinas (2007) e Pós Doutorado em Ecologia da Restauração (Embrapa Fechado). Atualmente é professora Associado Nível 2 da Universidade Federal da Grande Dourados, Tutora do Grupo PET Ciências Biológicas, tem experiência na área de Botânica, com ênfase em Taxonomia Fanerogâmica, trabalhando com Rubiaceae, Biologia Reprodutiva, Sustentabilidade, produtos de floricultura e Recuperação de Áreas Degradadas.

\section{RAIMUNDO MARLY CARVALHO DE FARIAS NETO}

Engo Agrônomo pela Universidade Federal Rural da Amazônia (UFRA) 


\section{RENATA PIRES BATISTA}

Graduanda em Agronomia pela Universidade Federal de Goiás em Goiânia, foi estagiária no Programa de Assistência a Bovinocultura Leiteira da UFG (2014/2015). Atualmente é membro do Grupo de Estudos em Manejo Agroecológico dos Solos (GEMAS/UFG), e do Grupo de Estudos Agronômicos em Bioenergia (GEABE/UFG).

\section{RODRIGO SIMÃO CAMACHO}

Doutor em Geografia pela Universidade Estadual Paulista Júlio de Mesquita Filho (Unesp/Presidente Prudente). Realizou Pós-doutorado em Geografia pela Universidade Federal de Mato Grosso do Sul (UFMS/Três Lagoas). É graduado e mestre em Geografia pela UFMS. Docente do curso de Licenciatura em Educação do Campo (LEDUC) da Faculdade Intercultural Indígena (FAIND) na Universidade Federal da Grande Dourados (UFGD). Docente no Programa de PósGraduação em Educação e Territorialidade (PPGET) na FAIND/UFGD. Docente do Programa de Pós-Graduação em Geografia da Faculdade de Ciências Humanas (FCH) da UFGD e da UFMS campus de Três Lagoas.

\section{ROSÁLIA DO NASCIMENTO DA SILVA}

Bióloga, Mestranda do Programa de Pós Graduação em Stricto Sensu em Biodiversidade e Agroecosistemas Amazônicos (PPGBioAgro) pela Universidade do Estado do Mato Grosso (UNEMAT)

\section{ROSIMARA BARBOZA BISPO}

Mestranda do Programa de Pós Graduação em Stricto Sensu em Genética e Melhoramento de Plantas pela Universidade Estadual do Norte Fluminense Darcy Ribeiro (UENF)

\section{ROSIMEIRE BARBOZA BISPO}

Mestranda do Programa de Pós Graduação em Stricto Sensu em Biotecnologia Vegetal pela Universidade Estadual do Norte Fluminense Darcy Ribeiro (UENF)

\section{SABRINA POLICARPIO SOUZA CAMPOS}

Cursa licenciatura em Geografia na Universidade Federal de Mato Grosso do Sul, Câmpus de Aquidauana (2017-atual). Possui formação técnica em Meio Ambiente na Escola Técnica de Itanhaém-SP (2014-2015). Realizou estágio voluntário no Parque Nacional da Chapada dos Veadeiros (2016) e participou do curso de Formação de Multiplicadores em Agricultura Sintrópica realizado Centro de Pesquisa em Agricultura Sintrópica (CEPEAS) em parceria com o ICMBIO no município de Alto Paraíso do Goiás (2018). Atualmente é membro do projeto de ensino do Coletivo de Agroecologia e do Diretório Acadêmico da UFMS-CPAq.

\section{SALMA SARÁTY DE CARVALHO}

Graduação em Ciências Econômicas, Mestrado em Ciências Ambientais, Doutorado em andamento em Ciências Ambientais

\section{SALVADOR ADAME MARTÍNEZ}

Possui Mestrado e Doutorado pelo Colégio de Pós-graduação de Chapingo, México. É Geógrafo formado na Universidade Nacional Autônoma do México (UNAM). É Professor pesquisador da Faculdade de Planejamento Urbano e Regional da UAEMex. Atua nas linhas de pesquisa: manejo de recursos naturais; conservação de solos; Bacias hidrológicas e teledetecção. 


\section{SERINEI CÉSAR GRÍGOLO}

Doutorado em Extensão Rural pela Universidade Federal de Santa Maria (2016). Possui graduação e mestrado em Agronomia pela Universidade Federal de Pelotas (1993 e 1996 respectivamente). Atualmente é professor de Extensão e Desenvolvimento Rural e de Planejamento de Propriedades na Universidade Tecnológica Federal do Paraná, campus Dois Vizinhos. Atuou por 10 anos em organizações populares com trabalhos orientado a agroecologia.

\section{SHIRLEY SANTOS MONTEIRO}

Bacharel em Agroecologia pela Universidade Federal da Paraíba (UFPB) Centro de Ciências Humanas, Sociais e Agrárias (CCHSA) Campus III, Bananeiras-PB (2011-2016) Mestre em Tecnologia Agroalimentar (PPGTA) pela Universidade Federal da Paraíba (UFPB) Centro de Ciências Humanas, Sociais e Agrárias (CCHSA) Campus III, Bananeiras-PB (2016-2018). Atualmente está cursando o Técnico em Agropecuária pelo Colégio Agrícola Vidal de Negreiros.

\section{TAINARA RAFAELY DE MEDEIROS}

Acadêmica de Bacharelado em Agronomia pela Universidade do Estado de Mato Grosso campus Alta Floresta. Com experiencia em Laboratório de Microbiologia e Fitopatologia.

\section{THOMÁS FLORIANO BOSCAINE}

Possui graduação em Ciências Biológicas pela Universidade Federal de Mato Grosso do Sul(2018). Tem experiência na área de Agroecologia, com ênfase em agroecossistemas florestais. É membro do Grupo de Agroecologia AHOW, em Três Lagoas/MS.

\section{TIAGO FARIAS PENICHE}

Engo Agrônomo pela Universidade Federal Rural da Amazônia (UFRA) Mestrando em Agricultura no Trópico Úmido (INPA)

\section{TORGESKI, MARIELE RAMONA}

Licenciada em Ciencias Biológicas pela Universidade Federal da Grande Dourados-UFGD / Faculdade de Ciências Biológicas e Ambientais- FCBA, Amiga do Programa de Educação Tutorial de Ciências Biológicas-PETBio e Mestranda no programa de pós graduação em Biodiversidade e meio ambiente.

\section{VANISLENE BORGES DA SILVA}

Atualmente discente de agronomia da Universidade Federal de Goiás - UFG, situada em Goiânia no campus samambaia. Membro do grupo de estudos em manejo agroecológico dos solos, desenvolvendo atividades de assistência técnica rural, estagiara do Centro Vocacional Tecnológico - CVT Apinajé - Formação de Jovens e Mulheres. Professora de Olericultura, no projeto Mais Educação realizado pela prefeitura de Goiânia na Escola Municipal Maria Clara Machado; membro da Consultoria Junior - CIPPAL, como gerente nas áreas de Gestão de Pessoas e Departamento de Projetos, atividades realizadas entre os anos de 2013 a 2015. Pesquisadora no Território Estrada de Ferro, desenvolvendo atividades como docente auxiliar da disciplina Manejo dos Solos, na Escola Familiar Agrícola de Orizona - Go (EFAORI).

\section{VERA LÚCIA PEGORINI ROCHA}

Bióloga, Mestranda do Programa de Pós Graduação em Stricto Sensu em Biodiversidade e Agroecosistemas Amazônicos (PPGBioAgro) pela Universidade do Estado do Mato Grosso (UNEMAT) 


\section{WALMOR MOIA PERES}

Engenheiro agrônomo e professor na Universidade do Estado do Mato Grosso (UNEMAT).

\section{WALMOR MOYA PERES}

Possui graduação em Engenharia Agronômica pela Universidade Federal de Mato Grosso (1995) e mestrado em Agricultura Tropical pela Universidade Federal de Mato Grosso (2001). É docente da educação superior, com o cargo de professor da educação superior nível 6 da Universidade do Estado de Mato Grosso - UNEMAT, Campus Universitário de Alta Floresta. Atualmente é Doutorando pela Universidade Estadual Paulista Júlio de Mesquita Filho - UNESP, Campus de Ilha Solteira

\section{WARDE ANTONIETA DA FONSECA ZANG}

Atual pesquisadora de projetos com a Alemanha e coordenadora de projeto CNPq e internacional Fapeg/Newton Fund. Professora no Instituto Federal de Educação Ciência e Tecnologia de Goiás IFG Campus Goiânia, (1992-2019), doutorado em Ciências Naturais pela Johannes Gutenberg Universität Mainz, Alemanha (1993-1997). Pós-doutorado pela UFG e Universität Rostock/FZJülich, Alemanha (2014-2015). Disciplinas de Química Inorgânica, Mineralogia, Metodologia da Pesquisa e Meio Ambiente/Ciência Ambiental. Pesquisa na Área do Desenvolvimento Sustentável com grupo de trabalho da Universidade de Ciências Aplicadas de Trier na Alemanha, pelo Projeto de Cooperação e Intercâmbio financiado pelo governo da Alemanha - DAAD (2004-2008).

\section{WILLIAMS JORGE DA CRUZ MACÊDO}

Graduação em Farmácia Bioquímica, Mestrado em Química, Doutorado em Química

\section{WILSON MOZENA LEANDRO}

Graduação em Engenharia Agronômica pela Universidade Estadual Paulista Júlio de Mesquita Filho (1987), mestrado em Solos e Nutrição de Plantas pela Escola Superior de Agricultura Luiz de Queiroz (1992) e doutorado em Produção Vegetal pela Universidade Federal de Goiás (1998). Atualmente é Prof Titular da Universidade Federal de Goiás. Ministra as disciplinas Manejo de Solos e Manejo Agroecológico do solo na graduação da Agronomia e as disciplinas Manejo de Solos em Sistema de Plantio Direto e Métodos Instrumentais e Análises Laboratoriais no programa de pós-graduação em Agronomia; áreas de concentração Produção Vegetal e Solo e Aguá.

\section{ZEFA VALDIVINA PEREIRA}

Graduação em Ciências Biológicas pela Universidade Federal de Mato Grosso do Sul (2000), mestrado em Botânica pela Universidade Federal de Viçosa (2003), doutorado em Biologia Vegetal pela Universidade Estadual de Campinas (2007) e Pós Doutorado em Ecologia da Restauração (Embrapa Cerrado). Atualmente é professora associada nível 2 da Universidade Federal da Grande Dourados. 


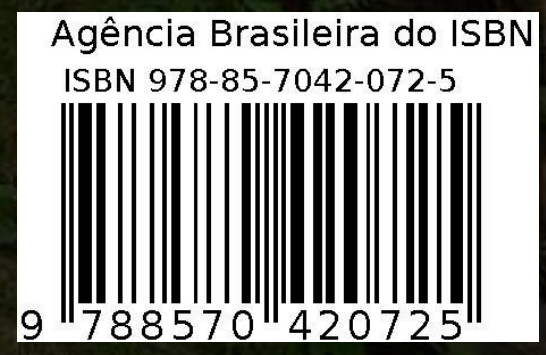

